RENATA ORSI BULGUERONI

\title{
Negociação coletiva e fontes do Direito do Trabalho: propostas para a prevalência do negociado sobre o legislado nas relações de emprego
}

Tese apresentada à Banca Examinadora do Programa de Pós-Graduação em Direito, da Faculdade de Direito da Universidade de São Paulo, como exigência parcial para a obtenção do título de Doutora em Direito, na área de concentração Direito do Trabalho e Seguridade Social, sob a orientação do Professor Titular Dr. Nelson Mannrich.

UNIVERSIDADE DE SÃO PAULO

FACULDADE DE DIREITO

São Paulo - SP 
Nome: Bulgueroni, Renata Orsi.

Título: Negociação coletiva e fontes do Direito do Trabalho: propostas para a prevalência do negociado sobre o legislado nas relações de emprego

Tese apresentada à Banca Examinadora da Faculdade de Direito da Universidade de São Paulo como exigência parcial para a obtenção do título de Doutora em Direito do Trabalho e Seguridade Social.

\section{Aprovada em:}

Banca Examinadora

Prof.

Julgamento:

Prof.

Julgamento:

Prof.

Julgamento:

Prof.

Julgamento:

Prof.

Julgamento:
Instituição:

Assinatura:

Instituição:

Assinatura:

Instituição:

Assinatura:

Instituição:

Assinatura:

Instituição:

Assinatura: 


\section{RESUMO}

Revisitar conceitos clássicos do Direito do Trabalho faz-se necessário perante os novos anseios de empregados e empregadores, decorrentes de um mercado econômico global e multifacetado. O pluralismo das fontes trabalhistas torna imperioso o reconhecimento dos frutos da negociação coletiva (i.e., acordos, convenções e contratos coletivos de trabalho) como autênticas fontes de Direito. Por seu turno, a incapacidade de a legislação consolidada disciplinar as novas realidades econômicas exige a restruturação dos conflitos entre lei e contratação coletiva, questionando-se a efetiva abrangência do princípio da norma mais favorável. É o que demonstram, com efeito, as experiências vivenciadas por Estados estrangeiros, como Portugal, Espanha, França e Itália, onde a legislação cede cada vez mais espaço aos interlocutores sociais. Cumpre adaptar tais experiências ao modelo brasileiro, ainda que marcado por sindicalismo contraditório e com resquícios corporativistas. Do contrário, há o risco de se comprometer ainda mais a efetividade da legislação protecionista, enfraquecida pela atuação de empresas que buscam, a todo custo, reduzir encargos laborais. Propõe-se, dessa maneira, o fortalecimento da negociação coletiva em solo pátrio, a fim de reconhecer aos sindicatos (independentemente de qualquer reforma sindical prévia) a possibilidade de alterarem a legislação in peius, diante das necessidades concretas de cada relação trabalhista. Porém, tal atuação não será ilimitada: além da celebração de acordos específicos por empresa, devem-se precisar quais matérias podem ou não ser objeto de derrogação negocial, sob pena de comprometer o princípio da proteção, pilar do Direito do Trabalho.

PALAVRAS-CHAVE: pluralismo jurídico; monismo jurídico; negociação coletiva; princípio do favor; princípio da norma mais favorável; favor laboratoris; contrato coletivo; interlocutores sociais; revisitação do Direito do Trabalho; modelo negociado; modelo legislado. 


\begin{abstract}
It is necessary to reanalyze some traditional concepts of Labor Law, confronting them with the new expectations of employers and employees in a global and multifaceted economic society. The pluralism of labor sources is essential to recognize that the fruits of collective bargaining (i.e., conventions and collective labor agreements) are authentic sources of legal laws. Furthermore, the failure of the legislation on disciplining the new economic realities requires the restructuring of the conflicts between law and collective bargaining, in order to question the dimension of favor laboratoris principle. This questioning has been occurring in several foreign countries, such as Portugal, Spain, France and Italy, where the state law conceives, gradually, more and more space to social partners on regulating labor conditions. It is necessary to adapt these experiences to the Brazilian model, although marked by contradictory and corporative trade unions. Otherwise, there will always be the risk of compromising the effectiveness of protective legislation, weakened by companies that seek, only, to reduce labor costs. Therefore, collective bargaining shall be strengthened, in order to recognize trade unions (regardless of any previous reform) the possibility of changing law in peius, in accordance with concrete needs of the labor relationship. However, such action would not be unlimited: all the agreements celebrated shall be specific by company, and furthermore it will be necessary to specify which themes may or may not be negotiated, in order to preserve the protection, the main pillar of Labor Law.
\end{abstract}

KEYWORDS: legal pluralism; legal monism; collective bargaining; principle of favor; favor laboratoris; collective agreements; social partners; trading model; legislated model. 


\section{RIASSUNTO}

La rivisitazione dei concetti classici del Diritto del Lavoro è necessaria di fronte alle nuove attese dei datori di lavoro e dei lavoratori, derivanti da un mercato economico globale e multiforme. Il pluralismo delle fonti di lavoro è fondamentale per riconoscere che i frutti della contrattazione collettiva (ad esempio, gli accordi, le convenzioni e i contratti collettivi di lavoro) sono autentiche fonti del Diritto. A sua volta, l'incapacità della legislazione consolidata a disciplinare le nuove realità economiche richiede la rimodulazione del conflitto tra la legge e la contrattazione collettiva, mettendo in discussione l'effettiva portata del principio della norma più favorevole. Questo occorre, infatti, con diversi paesi stranieri, come Portogallo, Spagna, Francia e Italia, dove la legge concede troppo spazio alle parti sociali per regolare i suoi interessi. Bisogna applicare queste esperienze al modello brasiliano, anche se esto è segnato da un sindacalismo contraddittorio e corporativo. In caso contrario, ci sarà il rischio di compromettere l'efficacia della legislazione protettiva, grazie all'attuazione di aziende che cercano, solo, a ridurre i costi del lavoro. Si propone, in questo modo, il rafforzamento della contrattazione collettiva al fine di riconoscere i sindacati (indipendentemente dalla riforma sindacale) la possibilità di modificare la legge in peius, a causa di esigenze concrete del rapporto lavoristico. Tuttavia, tale attuazione non sarebbe illimitata: potrà svolgersi soltanto tramite accordi specifici per azienda e si dovranno specificare quali materie possono o no essere negoziate, assicurandosi l'applicazione del principio di protezione, pilastro del Diritto del Lavoro.

PAROLE CHIAVI: pluralismo giuridico; monismo giuridico; contrattazione collettiva; principio di favore; principio della norma più favorevole; favor laboratoris; contratto collettivo; parti sociali; rivisitazione del Diritto del Lavoro; modello negoziato; modello legiferato. 


\section{SUMÁRIO}

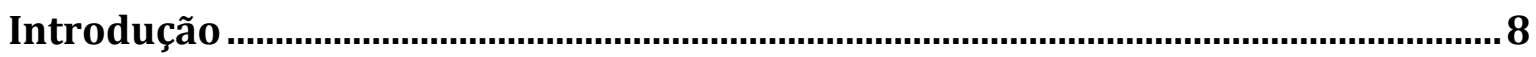

1. Pluralismo de fontes no Direito do Trabalho..................................................... 14

1.1. Contraposição entre monismo e pluralismo jurídico …...........................................14

1.2. Ascensão, desenvolvimento e declínio do monismo jurídico......................................17

1.3. Ressurgimento e reinvenção do pluralismo jurídico ..................................................24

1.4. Pluralismo jurídico e desenvolvimento do Direito do Trabalho..............................36

1.5. Sistema de fontes trabalhistas e novo pluralismo jurídico ......................................43

2. Acordos e convenções coletivas enquanto fonte do Direito do Trabalho ....... 49

2.1. Fontes do Direito sob o viés trabalhista ................................................................49

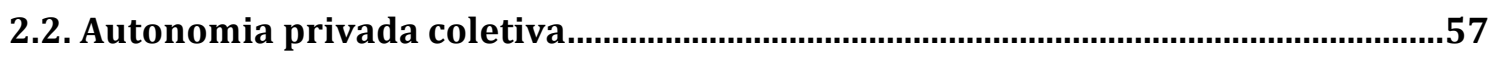

2.3. Interesse coletivo

2.4. A natureza de fonte dos acordos e convenções coletivas de trabalho.....................71

2.4.1. Questão terminológica: o "contrato coletivo de trabalho" .............................................. 71

2.4.2. 0 contrato coletivo enquanto fonte: entendimentos doutrinários................................ 73

2.4.3. A posição do ordenamento brasileiro .............................................................................. 80

3. Fontes trabalhistas e princípio da norma mais favorável ..................................... 84

3.1. O princípio da norma mais favorável enquanto orientador da relação entre

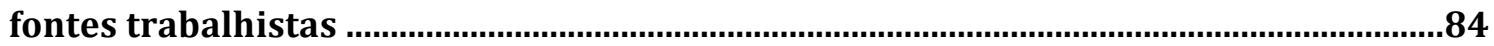

3.2. 0 princípio da norma mais favorável na legislação .................................................91

3.3. Relações entre lei e acordos e convenções coletivas de trabalho na atual

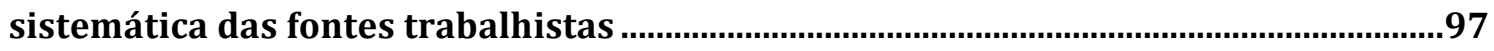

4. Rediscussão do princípio da norma mais favorável: os novos contornos do

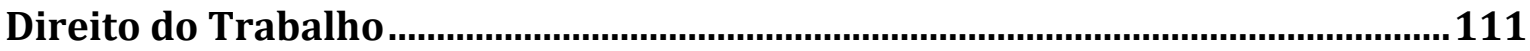

4.1. Aspectos introdutórios: "crise" do Direito do Trabalho e flexibilização mediante

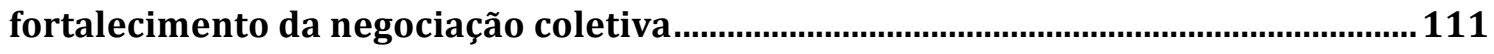

4.2. Rediscussão do princípio da norma mais favorável: aspectos doutrinários ..... 119

4.3. Rediscussão do princípio da norma mais favorável: alterações legislativas..... 127

4.3.1. A experiência portuguesa .................................................................................................127

4.3.2. A experiência espanhola ……………………………………………………………......141

4.3.3. A experiência italiana .....................................................................................................160 


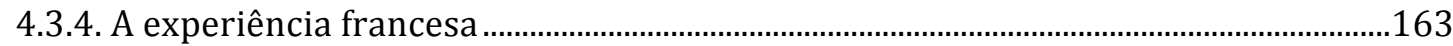

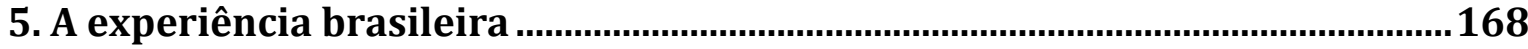

5.1. A necessária devolução de poder aos corpos sociais ...............................................168

5.2. A flexibilização de direitos na legislação brasileira ................................................ 173

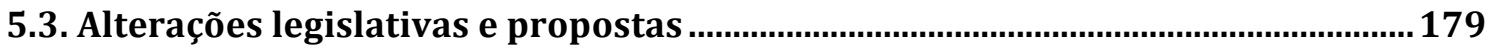

6. Bases e limites para a adoção, no Brasil, do modelo negociado …….................200

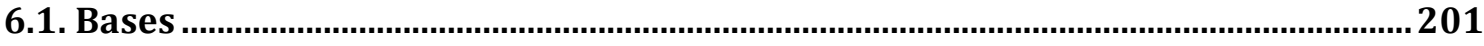

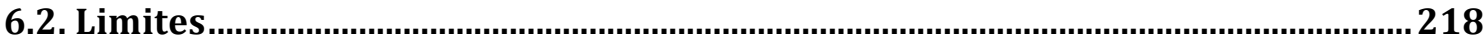

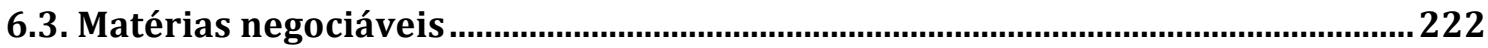

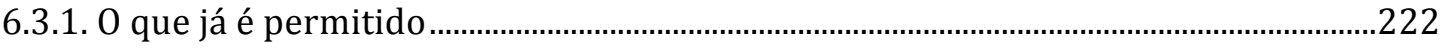

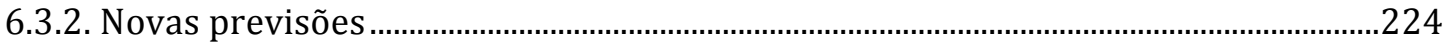

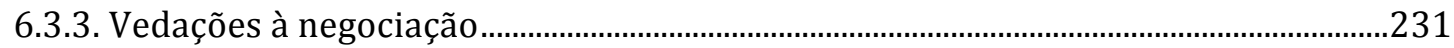

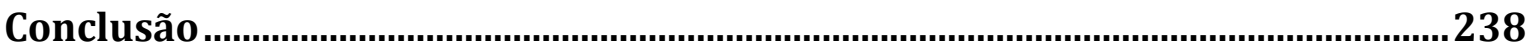

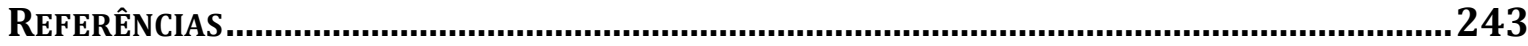




\section{Introdução}

A necessidade de revisitar o estudo de instituições-chave do Direito do Trabalho é inerente às transformações que tal ramo vem enfrentando no novo cenário econômico internacional, caracterizado por relações de trabalho multifacetadas e mercados globais, porém descentralizados. É preciso, nesse sentido, abordar temas clássicos - como negociação coletiva, hierarquia das fontes e princípios - sob viés diferenciado, pensando em sua adaptação às relações trabalhistas contemporâneas.

Surgem, nesse contexto, questionamentos acerca do real alcance do princípio da proteção, especialmente diante de conflitos entre normas trabalhistas. $\mathrm{O}$ princípio da norma mais favorável (princípio do favor ou favor laboratoris) é colocado em xeque por ordenamentos jurídicos - sobretudo europeus - que atribuem prevalência à negociação coletiva na regulamentação das condições do trabalho. A pirâmide do favor, em que se estruturou o Direito do Trabalho, cede espaço a modelo horizontal, no qual os atores sociais restam legitimados a tutelar seus próprios interesses, até mesmo contrariamente à legislação.

As modificações do mercado e do próprio objeto tutelado pelo Direito do Trabalho, com efeito, ensejam questionamentos envolvendo a interação da lei e da negociação coletiva. Assim, por exemplo, quem é o sujeito legitimado para ditar o que é melhor ao trabalhador: o Estado - com visão global das relações de trabalho - ou o sindicato - com visão específica dos interesses de determinada categoria? Ainda, a inderrogabilidade de direitos previstos em lei é de natureza absoluta ou relativa? Se absoluta, justifica-se em um cenário econômico internacional cada vez mais competitivo? Se relativa, em que situações poderia ser afastada e a quem caberia determinar tais situações?

Trata-se, em síntese, de examinar se a negociação coletiva poderia sobrepor-se à lei, não para regular situações mais favoráveis ao trabalhador - como já é admitido, por força da aplicação do mencionado princípio da norma mais favorável -, mas para derrogá-la ou alterá-la in peius, atendendo aos interesses concretos de empregados e empregadores. Em outras palavras: poderia o modelo negociado prevalecer sobre o legislado - especialmente em um sistema de sindicalismo contraditório, como o brasileiro? 
A centralização da função legislativa na figura do Estado, com caráter protecionista, permitiu a afirmação do Direito do Trabalho como ciência autônoma em relação ao Direito Civil. Embora a negociação coletiva seja inerente ao próprio trabalho humano, sua capacidade normativa foi abafada quando o Estado decidiu intervir nas relações trabalhistas, chamando para si a responsabilidade pela "questão social" que se arvorava com a Revolução Industrial.

Por seu turno, a natureza protecionista que sempre acompanhou referido ramo do Direito mostrou-se essencial em ambiente marcado por interesses homogêneos, de uma classe trabalhadora também uniforme. A sociedade predominantemente industrial ensejou o surgimento e a proliferação da figura do "operário padrão", i.e., o pai de família que necessita do emprego para sobreviver e, por tal razão, desempenha-no com o maior zelo e a maior dedicação possíveis, cumprindo horário rígido e se sujeitando a quaisquer ordens emanadas do empregador - algo similar ao bonus paterfamilias da civilização romana, porém marcado pela plena submissão em relação ao tomador de serviços.

Contudo, na sociedade pós-industrial, em que predomina o setor de serviços, a figura do operário padrão cede espaço a outras espécies de trabalhador muitas, inclusive, com amplo poder de negociação junto ao empregador. A antes homogeneidade da classe operária coloca-se em xeque diante de formas de prestação de serviços alheias ao objeto tradicional do Direito do Trabalho, como teletrabalho, terceirização, cooperativas, trabalho autônomo dependente, pejotização, etc.

Longe de se dar "adeus" ao trabalho - como propugnado por alguns -, é necessário lidar com essas novas situações, considerando-se, ainda, o ambiente de extrema competitividade e internacionalização dos mercados. É preciso reconhecer que o formalismo excessivo da legislação protetora dificulta a atuação das empresas, que acabam-se valendo de odiosos expedientes de contratação irregular e da adaptação da lei para "fugir" dos excessos legais.

De rigor, assim, a rediscussão do sistema de fontes trabalhistas e do papel da negociação coletiva na modulação das normas legais.

Justifica-se a escolha do tema em virtude da escassa produção doutrinária, no Brasil, sobre o assunto. Como mencionado, especialmente em países europeus, a revisitação do princípio da norma mais favorável vem sendo gradativamente efetuada pela doutrina e pela própria legislação, em regras que contemplam novas relações 
entre lei e negociação coletiva. No Brasil, ao contrário, sobretudo após o engavetamento do Projeto de Lei $\mathrm{n}^{\mathrm{o}} 5.483 / 2001$ - o qual, como adiante se verá, pretendeu a implementação do modelo negociado no país -, praticamente cessaram as discussões (mesmo doutrinárias) a respeito da possibilidade de conferir papel diferenciado aos sindicatos na adaptação da lei.

Cumpre retomar tais discussões, especialmente diante de nova proposta de superação do modelo estritamente legislado (apresentada, em 2011, pelo Sindicato dos Metalúrgicos do $\mathrm{ABC}$ Paulista) e da própria disciplina constitucional, que - sobretudo no art. $7^{\circ}$, incisos VI, XII, XIV e XXVI -, reconheceu expressa legitimidade ao sindicato para atuar no processo de flexibilização de condições de trabalho.

Além disso, o tema torna-se ainda mais instigante por ser desenvolvido em sistema sindical de contradições e resquícios corporativistas, no qual os sindicatos são vistos com desconfiança e incredulidade por grande parte da população. Como compatibilizar, assim, o mandamento constitucional de flexibilização pelo negociado com tal sistema?

O primeiro capítulo do presente estudo - que tem intuito, apenas, de estruturar as bases para a tese defendida - abordará o pluralismo jurídico no Direito do Trabalho, a partir de análise histórica de seu surgimento, sua contraposição ao monismo jurídico e as modernas teorias que propõem sua adaptação à sociedade contemporânea. $\mathrm{O}$ capítulo tem por escopo propor a revisitação do tema no âmbito juslaboral, reconhecendose a existência de autêntica pluralidade de fontes no Direito do Trabalho.

Complementando os estudos efetuados no primeiro capítulo, o segundo analisará os frutos da negociação coletiva (i.e., convenções, acordos coletivos e contratos coletivos) enquanto fontes do Direito do Trabalho, passíveis de ensejar conflitos com a normativa estatal. Nessa ocasião, será examinada a experiência estrangeira de positivação de referidos frutos enquanto fonte de Direito para, ao final, tecerem-se comentários sobre o modelo brasileiro.

Pensando-se nos conflitos entre lei e frutos da negociação coletiva, o terceiro e quarto capítulos abordarão as regras sobre hierarquia de fontes, em especial o princípio da norma mais favorável. Enquanto, no terceiro capítulo, apresentar-se-á visão clássica sobre o tema (inclusive demonstrando-se a experiência estrangeira na consagração legal de tal princípio), o quarto capítulo tratará de pontos controvertidos envolvendo o 
favor laboratoris: flexibilização mediante negociação coletiva, questionamentos doutrinários sobre sua efetiva aplicação às relações trabalhistas hodiernas e experiências estrangeiras de revisitação do princípio, atribuindo prevalência à autonomia coletiva.

A partir de então, inicia-se a análise da experiência brasileira. O capítulo cinco destina-se a esmiuçar os entendimentos doutrinários a respeito da necessária devolução de poderes aos atores sociais - poderes que foram solapados com a centralização da normativa trabalhista na figura do Estado. Também se remeterá, nesse capítulo, às experiências de flexibilização ocorridas no Brasil, buscando apontar aspectos comuns entre elas. Aproximando-se da tese a ser defendida, serão examinadas todas as propostas de alteração da legislação brasileira para se atribuir preferência à negociação na disciplina das relações de trabalho - culminando com a análise do inovador projeto apresentado, em 2011, pelo Sindicato dos Metalúrgicos do ABC Paulista.

Sedimentadas as bases nos capítulos precedentes, o capítulo seis apresentará proposta de adoção do modelo negociado em terras pátrias, expondo os limites para sua implementação e especificando quais matérias poderão, ou não, ser objeto da negociação coletiva in peius.

Algumas questões formais envolvendo o presente trabalho devem ser apontadas neste momento.

Inicialmente, sabe-se que a realidade de Estados estrangeiros é, na grande maioria das vezes, muito distinta da brasileira. Por força de tal argumento, lamentavelmente, é escassa a produção científica de temas de direito comparado aplicáveis ao Brasil.

Entretanto, entende-se que a comunidade acadêmica tem o dever, perante a sociedade, de propor soluções para a adequação do sistema pátrio às necessidades atuais do mercado de trabalho. Para tanto, por que não se basear em experiências de outros países? Seus fracassos podem, inclusive, fornecer dados do que não deve ser adotado em solo pátrio.

Não por outro motivo, aliás, no curso de Pós-Graduação da Faculdade de Direito da Universidade de São Paulo (USP), promoveu-se série de disciplinas acerca da Reforma do Direito do Trabalho Individual e Coletivo na Itália, Espanha, França e Portugal - as quais serviram, diretamente, de inspiração para o presente trabalho. 
Com relação à metodologia, utilizou-se, inicialmente, o método dialético para exame das posições doutrinárias antagônicas a respeito de cada problema apresentado e análise de decisões jurisprudenciais divergentes; para tanto, fez-se imprescindível, por óbvio, o método de coleta de jurisprudência.

Também se mostrou essencial o método comparativo, pois, como salientado, o exame de legislação, doutrina e jurisprudência estrangeiras mostra-se vital para a compreensão da experiência comparada, sobretudo, em matéria de contrato coletivo e revisitação do princípio do favor. Nesse ponto, também se fez uso - ainda que brevemente - do método histórico, efetuando-se regressão da legislação estrangeira (e também brasileira) para análise da evolução dos institutos.

O método indutivo foi necessário à identificação do panorama do contrato coletivo no Brasil; ainda, o método sistemático revelou-se fundamental na análise dos textos legais relativos ao tema, tanto brasileiros, quanto estrangeiros. Não foi utilizado, porém, o método estatístico, vez que a pesquisa não se destina a apresentar índices e dados concretos sobre o assunto ora examinado, e sim a propor soluções para o seu tratamento jurídico.

Com relação às fontes, foram utilizados, primordialmente, textos legislativos nacionais e estrangeiros que disciplinam a matéria, bem como foi realizada pesquisa jurisprudencial, em consulta a sítios virtuais de tribunais brasileiros e estrangeiros.

No que tange ao material, lançou-se mão do acervo da biblioteca da Universidade de São Paulo - USP, bem como de livros adquiridos no decorrer da pesquisa. Obras encontradas em outras bibliotecas e sites da Internet também foram consultadas, além de servirem como material complementar artigos de periódicos, dissertações de mestrado e teses de doutorado sobre o tema.

O método bibliográfico empregado é o contido nas normas da ABNT Associação Brasileira de Normas Técnicas, por determinação das resoluções que regem o curso de Pós-Graduação da Faculdade de Direito da Universidade de São Paulo (USP).

Importante, ainda, tecer breves considerações a respeito da terminologia utilizada no trabalho.

Em primeiro lugar, verificar-se-á que as expressões "norma mais favorável", "favor laboratoris" e "princípios do favor" foram utilizadas como sinônimas 
no decorrer da exposição. No mesmo sentido, ao se tratar dos poderes a serem atribuídos à contratação coletiva, as expressões "atores sociais", "partes sociais" e "interlocutores sociais" foram igualmente empregadas para designar os legitimados a negociar.

Por seu turno, o termo "contrato coletivo de trabalho" adquire diversos significados ao longo do estudo - cada um explicitado quando de sua utilização.

Sabe-se que qualquer tentativa de revisitação de conceitos clássicos pertencentes a um ramo da ciência jurídica apresenta inúmeros riscos. Porém, são justamente os riscos que tornam bela e instigante a atividade acadêmica, e incentivam o estudioso a enfrentar os tortuosos caminhos da pesquisa científica. 


\section{Pluralismo de fontes no Direito do Trabalho}

\subsection{Contraposição entre monismo e pluralismo jurídico ${ }^{1}$}

A compreensão do atual sistema de fontes do Direito do Trabalho, bem como da correlação entre as normas estatais e aquelas emanadas dos grupos sociais, passa, obrigatoriamente, pelo estudo dos modelos monista e pluralista de produção normativa os quais marcaram a história das instituições jurídicas e, ainda hoje, inspiram debates nos mais variados ramos do Direito. ${ }^{2}$

Com efeito, o reconhecimento de que múltiplas são as fontes trabalhistas - ademais das normas produzidas exclusivamente pelo Estado - demanda análise pormenorizada do pluralismo jurídico na sociedade hodierna. A aceitação do Estado enquanto único detentor do poder-dever de produzir leis (teoria justificada pelo monismo jurídico) é incompatível com o atual modelo de relações trabalhistas, marcado pela pluralidade de sujeitos aptos a determinar condições de trabalho aplicáveis a situações concretas, e se contrapõe à tese que ora se pretende defender, qual seja, da necessidade de prevalência do modelo negociado sobre o legislado.

Nesse sentido, como bem ressalta Amauri Mascaro Nascimento, o pluralismo jurídico beneficia o sindicalismo porque seu oposto, o monismo jurídico, ao negar a possibilidade de se reconhecer direito não-estatal, “criaria um sério problema

\footnotetext{
1 O termo "pluralismo" tem acepções diversas, podendo referir-se ao pluralismo político, cultural, econômico, social ou jurídico. Apegando-se ao tema proposto, examinar-se-á tão somente o pluralismo jurídico, isto é, o pluralismo sob o ponto de vista da produção de normas jurídicas.

${ }^{2}$ Assim, e.g., destacam-se discussões a respeito do pluralismo jurídico no Direito Penal (MARTINS, José Maria Ramos e Marques Neto, Agostinho Ramalho. Pluralismo Jurídico e Novos Paradigmas Teóricos. Porto Alegre: Sergio Antonio Fabris Editor, 2005; BARBATO JR.. Pluralismo Jurídico e Criminalidade Brasileira. In WOLKMER, Antonio Carlos et al. Pluralismo Jurídico: os novos caminhos da contemporaneidade. $2^{\text {a }}$ edição. São Paulo: Saraiva, 2013, pp. 225-239), nos Direitos Humanos (WOLKMER, Antonio Carlos. Pluralismo jurídico: um espaço de resistência na construção dos direitos humanos. In Wolkmer, Antonio Carlos et al. Pluralismo Jurídico: os novos caminhos da contemporaneidade. $2^{\text {a }}$ edição. São Paulo: Saraiva, 2013, pp. 37-50), entre outros.
} 
sindical de liberdade e de operacionalidade porque difícil seria conciliar convenções coletivas de trabalho com o monismo estatal". ${ }^{3}$

Portanto, é necessário perquirir o conceito e as características essenciais do pluralismo jurídico - em contraposição ao monismo - para especificar suas implicações e limites na regulamentação das condições de trabalho pelos agentes sociais e, por fim, questionar: há efetivo pluralismo jurídico no Direito do Trabalho?

Parte-se, assim, da lição de Goffredo da Silva Telles Junior: "desde logo, cumpre observar que os grupos sociais, de que a sociedade global é constituída, são fontes inexauríveis de normas". 4

Nesse sentido, conforme entendimento da doutrina clássica, pluralismo jurídico pode ser definido como a coexistência de vários sistemas normativos na mesma sociedade política, que não apenas o Estado. ${ }^{5}$ Antonio Carlos Wolkmer, nessa linha, define pluralismo jurídico como a multiplicidade de práticas jurídicas existentes em um mesmo espaço sociopolítico, "interagidas por conflitos ou consensos, podendo ser ou não oficiais e tendo sua razão de ser nas necessidades existenciais e culturais". 6

Em outras palavras, é a negação de que o Estado seja o centro único do poder político e de toda a produção do Direto $^{7}$, ou o reconhecimento da diversificação de processos de formação das normas jurídicas ${ }^{8}$ - trata-se de "uma perspectiva descentralizadora e antidogmática que pleiteia a supremacia de fundamentos ético-políticosociológicos sobre critérios tecno-formais positivistas". 9

O pluralismo jurídico, contudo, não apresenta conceito doutrinário homogêneo. Nelson Mannrich, por exemplo, entende que, além da acepção acima descrita, pode-se atribuir outro sentido à noção de pluralismo jurídico: este ocorre quando as mesmas pessoas submetem-se a ordens jurídicas independentes. ${ }^{10}$ Por seu turno, Sergio

\footnotetext{
${ }^{3}$ Nascimento, Amauri Mascaro. Compêndio de Direito Sindical. $6^{\text {a }}$ ed.. São Paulo: LTr, 2011, p. 197.

4 Telles Junior, Goffredo da Silva. Em nome do povo... In Revista da Faculdade de Direito da Universidade de São Paulo - FDUSP, vol. 97, 2002, p. 231.

${ }^{5}$ Cf. Martins, Sergio Pinto. O pluralismo do Direito do Trabalho. Rio de Janeiro: Atlas, 2001, p. 21.

${ }^{6}$ Wolkmer, Antonio Carlos. Pluralismo Jurídico: fundamentos de uma nova cultura no direito. $3^{\mathrm{a}}$ ed. São Paulo: Alfa Omega, 2001, Introdução, p. XVI.

7 Conforme leciona MAGANO, Octávio Bueno. Liberalismo, corporativismo, pluralismo e neocorporativismo. In Revista da Faculdade de Direito da Universidade de São Paulo - FDUSP, vol. 87, 1983 , p. 56.

${ }^{8}$ Martins, Sergio Pinto. O pluralismo do Direito do Trabalho..., Op. Cit., p. 21.

${ }^{9}$ Wolkmer, Antonio Carlos. Pluralismo Jurídico: fundamentos..., Op. Cit., Introdução, p. XV.

${ }^{10}$ MAnnrich, Nelson. Pluralismo jurídico e Direito do Trabalho. In Revista do Advogado, Ano XXII, $\mathrm{n}^{\circ}$ 66, junho de 2002, São Paulo, p. 7.
} 
Pinto Martins, já citado, apresenta diversas definições do pluralismo, passando por aquela segundo a qual o pluralismo corresponde às ordens jurídicas autônomas que circundam o Direito, a que defende que se encontra na sociedade, e não no Estado, o centro de gravidade da ordem jurídica e a que pugna pelo poder legislativo das instituições, sendo as normas por elas criadas responsáveis pela própria formação do Direito como um todo. ${ }^{11}$

De qualquer maneira, a despeito das divergências acerca do conceito formal de pluralismo jurídico, todas partem de acepção comum: um fenômeno nascido no seio da própria sociedade, a qual, diante da multiplicidade de interesses verificados in concreto, anseia por uma também multiplicidade de direitos, capazes de fazer frente às necessidades do grupo social individualmente considerado. Dito de outro modo, o pluralismo jurídico surge em contraposição ao sistema conhecido como "monismo jurídico", o qual concentra no ente estatal a produção normativa.

O pluralismo jurídico, nesse sentido, indica o esgotamento do modelo jurídico liberal individualista, em xeque diante da nova sociedade plural, marcada por conflitos de massa e ansiosa por maior participação nos centros políticos de tomada de decisões. Segundo Wolkmer, as reivindicações de legitimação de novas formas normativas extra-estatais decorrem das contradições entre o que é prometido no Direito objetivo do Estado e o que é possível pelas condições objetivas do desencontro entre a racionalidade formal oficial e a racionalidade material - trata-se de um "novo paradigma societário de produção normativa". ${ }^{12}$

Como dito, o pluralismo jurídico advém da superação do modelo do monismo jurídico, predominante até meados do século XIX. Assim, antes de analisar com mais detença a pluralidade de centros de produção da norma, é necessário tecer breves considerações a respeito do modelo em que a criação legislativa encontra-se vinculada a uma só figura: o Estado.

\footnotetext{
${ }^{11}$ Martins, Sergio Pinto. O pluralismo do Direito do Trabalho..., Op. Cit., pp. 44-57.

12 Wolkmer, Antonio Carlos. Pluralismo Jurídico: fundamentos..., Op. Cit., Introdução, p. XIX. A respeito do tema, ainda, cf. SANTOS, Boaventura de Souza. Crítica de la Razón Indolente - Contra el desperdicio de la experiencia. Vol. 1. Bilbao: Editorial Desclée de Brouwer S.A., 2003, pp. 136 e ss.
} 


\subsection{Ascensão, desenvolvimento e declínio do monismo jurídico}

A estruturação de determinado sistema normativo relaciona-se diretamente com o paradigma histórico-social em que se insere. Nesse sentido, o surgimento do monismo jurídico coincide com a Idade Moderna (séculos XVI e XVII), momento em que o direito passa a ser identificado com a figura do Estado Absoluto, do monarca soberano.

Até então, no período da Idade Média, predominava sistema jurídico extremamente plural: o direito dos feudos era pulverizado e consuetudinário, desenvolvendo-se no âmbito de cada comunidade a partir do costume, das práticas sociais arraigadas. O poder era distribuído em um sem-número de centros: nobreza, clero, universidades e corporações de ofício. ${ }^{13}$ Valorizava-se concepção "corporativa" da sociedade, reconhecendo-se seu caráter multifacetado e plural - sem se afastar, entretanto, o papel supletivo e doutrinário de determinados centros normativos, como Direito Canônico, Direito Visigótico e Direito Romano. Os próprios tribunais eram criados e administrados pelo senhor feudal, permitindo a exteriorização das diferenças entre nobreza, clero e campesinato. ${ }^{14}$

Com o nascimento da burguesia, contudo, surge a necessidade de uniformização de procedimentos comerciais, com o intuito de melhor operacionalizar os negócios dessa nova classe em ascensão. Desenvolve-se, então, sistema jurídico de viés unitário, evidenciado pelo Direito Mercantil - um sistema que, porém, somente poderia ter efetividade se pautado na centralização político-administrativa na figura de um governante soberano, apto a conferir racionalidade lógico-formal centralizadora ao Direito. ${ }^{15}$

Conforme bem ressalta Boaventura de Souza Santos, embora o pluralismo jurídico do sistema feudal fosse, inegavelmente, fonte de liberdade, consistia em liberdade caótica, exercida somente em situações extremas - ao contrário do tipo de

\footnotetext{
${ }^{13}$ Martins, Sergio Pinto. O pluralismo do Direito do Trabalho..., Op. Cit., p. 27. Segundo Bobbio, até mesmo a família, considerada na tradição do pensamento cristão como uma societas naturalis, um ordenamento à parte (BoBBIO, Norberto. Teoria Geral do Direito. Martins Fontes: São Paulo, 2007, p. 11).

${ }^{14}$ Wolkmer, Antonio Carlos. Pluralismo Jurídico: fundamentos..., Op.. Cit., Introdução, p. 28.

${ }^{15}$ Como bem ressalta Wolkmer, "na verdade, a burguesa mercantil, ao suplantar a nobreza e o clero como nova classe social detentora dos meios de produção, busca adequar aos seus interesses uma ordem estatal fortalecida, apta a legitimar um sistema de normatividade. Esta ordenação, firmada na logicidade de regras genéricas, abstratas e racionalizadas, disciplina, com segurança e coerência, questões do comércio, da propriedade privada, da herança, dos contratos etc.”. WOLKMER, Antonio Carlos. Pluralismo Jurídico: fundamentos..., Op., cit., p. 47.
} 
liberdade por que ansiavam as classes mercantis urbanas, a qual deveria ser exercida com uma rotina igual à das transações efetuadas pela burguesia e que exigia proteção contra ingerências arbitrárias. ${ }^{16}$

Nasce, então, a concepção de que Estado e Direito estão intrinsecamente relacionados, aquele como único centro de poder capaz de controlar a criação e aplicação deste.

Nesse contexto, ganha relevo a teoria de Thomas Hobbes, um dos principais expoentes para a justificação do Estado soberano e unitário: sem um poder forte que os controle, os homens viveriam em estado de guerra generalizado e permanente, pois, no estado de natureza, são governados pelo instinto e, por isso, tendem a permanecer em situação de rivalidade. É necessário, assim, sair do estado de natureza, atribuindo-se plenos poderes ao soberano, para que se obtenham a ordem e a segurança. ${ }^{17}$

O mesmo pensamento pode ser encontrado em Rousseau: o contrato social é ato de renúncia aos direitos naturais, mas não em favor de um terceiro (Estado) e sim em favor dos semelhantes (corpo político). Esse corpo político, então, atribui a vontade geral ao Estado - a qual, por tal razão, pode ser considerada o único critério de justiça e, consequentemente, a única fonte do Direito. ${ }^{18}$

O surgimento do monismo jurídico, assim, coincide com a visão de mundo liberal-individualista da Idade Moderna, baseada no modo de produção capitalista e na concentração política no Estado Absoluto. As necessidades mercantis da burguesia ascendente e os anseios centralizadores do monarca soberano determinam a substituição da estrutura plural do feudalismo por uma instância unitária e exclusiva, que evidencie o extremo racionalismo da humanidade e afaste o controle sócio-político até então exercido pela Igreja. Nesse modelo, ainda, o costume - tão presente na Idade Média - passa a ter validade somente se reconhecido pela lei, e a jurisdição assume papel apenas secundário, de aplicação das normas jurídicas produzidas pelo Estado.

Segundo bem sintetiza Norberto Bobbio, o edifício construído pela ciência jurídica oitocentista apoiava-se em dois pilares: o estatalismo", i.e., "la concezione

\footnotetext{
${ }^{16}$ SAntos, Boaventura de Souza. Crítica de la Razón Indolente... Op. Cit., p. 136.

${ }^{17}$ Cf. Malmesbury, Thomas Hobbes de. Leviatã ou A matéria, forma e poder de um estado eclesiástico e civil. $3^{\mathrm{a}}$ edição. São Paulo: Í́cone, 2008.

${ }^{18}$ Cf. Rousseau, Jean-Jacques. Do contrato social ou Princípios do Direito Político. São Paulo: Martin Claret, 2008.

${ }^{19}$ Expressão utilizada pelo autor.
} 
che potremmo chiamare della monopolizzazione del diritto da parte dello stato, secondo la formula: non vi è altro diritto che il diritto statuale" 20 e o legalismo, exteriorizado pela fórmula: "non vi è altro diritto nello stato che il diritto legislativo".

O monismo jurídico assenta suas bases no estado revolucionário francês, quando se consolidam as teorias contratualistas e a estabilização da burguesia. ${ }^{22}$ Porém, seu verdadeiro ápice ocorre após as primeiras codificações da era moderna e, especialmente, com a ascensão da escola do positivismo jurídico - em período denominado por Wolkmer de "segundo ciclo do monismo jurídico"23 e por Nelson Mannrich de "sistematização" e "apogeu" do monismo. ${ }^{24}$

A escola do positivismo jurídico é marcada pela concepção de que o direito positivo é a expressão da vontade do Estado. Assim, de acordo com Wolkmer, nesse segundo ciclo, é perceptível a gradativa redução do Direito Estatal ao Direito Positivo, consagrando-se o entendimento de que todo o Direito não só é Direito enquanto produção do Estado, mas, sobretudo, de que somente o Direito Positivo é verdadeiramente Direito. $^{25}$

De fato, segundo Hans Kelsen, o Direito não se distingue do Estado, sendo este a personificação de todo o ordenamento jurídico. Assim, o conhecimento do Estado isento de elementos ideológicos (quer dizer, centrado na teoria pura do direito) permite que seja concebido como uma ordem de conduta humana. Embora usual a caracterização do Estado como uma organização política, tal caracterização, segundo o autor, apenas exprime que o Estado é uma ordem de coação - portanto, “como organização política, o Estado é uma ordem jurídica". ${ }^{26}$

Porém, continua referido autor, nem toda ordem jurídica é um Estado nem a ordem jurídica pré-estadual da sociedade primitiva, nem a ordem jurídica

\footnotetext{
20 “a concepção que podemos chamar de monopolização do direito pelo Estado, segundo a fórmula: não há outro direito que não o direito estatal" (tradução livre) (BOBBIO, Norberto. La consuetudine come fatto normativo. Torino: G. Giappichelli, 2010, p. 2).

21 "não há outro direito no Estado que não o direito legislativo" (tradução livre) (BoBBIO, Norberto. La consuetudine come fatto normativo... Op. Cit., p. 2). Com relação, especificamente, ao costume, Bobbio ressalta que este apenas adquire caráter normativo se expressamente reconhecido pela lei - portanto, não constitui direito válido, ou apresenta validade meramente reflexa.

${ }^{22}$ Entretanto, diferentemente do modelo anterior, após a Revolução Francesa, a lei aparece não como vontade do soberano, mas como materialização do Estado-Nação, i.e., do Estado enquanto vontade da nação soberana.

${ }^{23}$ WolKMer, Antonio Carlos. Pluralismo Jurídico: fundamentos..., Op. Cit., p. 51.

${ }^{24}$ MAnnrich, Nelson. Pluralismo jurídico e Direito do Trabalho..., Op. Cit., p. 9.

${ }^{25}$ Wolkmer, Antonio Carlos. Pluralismo Jurídico: fundamentos..., Op. Cit., p. 55.

${ }^{26}$ Kelsen, Hans. Teoria Pura do Direito. São Paulo: Martins Fontes, 1999, p. 200.
} 
internacional supra-estadual (ou interestadual) representam um Estado. Isso porque, para ser um Estado, a ordem jurídica precisa ser organizada, ou melhor, instituir órgãos funcionando segundo o princípio da divisão do trabalho para criação e aplicação das normas. ${ }^{27}$ Assim, a razão pela qual a ordem pré-estadual e a ordem internacional não podem ser consideradas verdadeiras ordens jurídicas repousa justamente no fato de suas normas não advirem de um órgão legislativo central, e sim da via consuetudinária - ou seja, trata-se de sistemas de pluralismo jurídico, rechaçados pelo autor como fontes de produção normativa.

Miguel Reale, ao analisar a teoria kelseniana, afirma que esta redunda em monismo normativista do ponto de vista da atividade jurisprudencial. Com efeito, para o positivismo, o jurista deve encarar a realidade como sistema de normas que se concatenam e se hierarquizam. Em outras palavras, “todo o mundo jurídico não é senão uma sequência de normas até atingir, sob forma de pirâmide, o ponto culminante da norma fundamental, que é 'condição lógico-transcendental' do conhecimento jurídico". ${ }^{2}$

Consequentemente, continua Reale, do ponto de vista normativo, não existe diferença entre Estado e Direito. Para o político ou o economista, haverá diferença; porém, "para o jurista, o Estado é o Direito enquanto subjetivado". Assim como toda regra jurídica pressupõe logicamente um sujeito, a totalidade do ordenamento jurídico deve pressupor um ponto geral de referência: a pessoa jurídica do Estado. ${ }^{29}$

Veja-se, dessa forma, a estreita relação entre monismo e positivismo jurídicos: na medida em que o direito emana exclusivamente do Estado, direito positivo e direito estatal tornam-se sinônimos, e o Estado detém o monopólio da produção das normas jurídicas. No entender de Nelson Mannrich, esse monopólio confere a tais normas atributos que não eram possíveis na ordem plural do feudalismo: hierarquia, segurança jurídica e certeza. ${ }^{30}$

Ademais, o monismo associado ao positivismo torna inviável qualquer referência a elementos subjetivos na produção legislativa: o monismo da teoria pura do direito elimina qualquer noção metajurídica e fática da norma, restando-lhe tão-somente o enfoque formalista e lógico da demonstração de sua validade. Conforme bem observa Lucas Borges de Carvalho, as normas jurídicas são recortadas ou descoladas da realidade

\footnotetext{
${ }^{27}$ Kelsen, Hans. Teoria Pura... Op. Cit., p. 200.

${ }^{28}$ ReAle, Miguel. Filosofia do Direito. $19^{\text {a }}$ ed. São Paulo: Saraiva, 2000, p. 476.

${ }^{29}$ REALE, Miguel. Filosofia do Direito..., Op. Cit., pp. 477-478.

${ }^{30}$ Mannrich, Nelson. Pluralismo jurídico e Direito do Trabalho..., Op. Cit., p. 9.
} 
social na qual se inserem, constituindo uma "realidade" autônoma e altamente abstrata, sobre a qual a dogmática jurídica exerce papel fundamental. ${ }^{31}$

Sintetizando os elementos caracterizadores do monismo jurídico, leciona Nelson Mannrich que os pressupostos ideológicos da doutrina monista assentam-se em quatro princípios: a) princípio da estatalidade: o direito moderno é o direito estatal, ou seja, somente pode ser considerado direito positivo o direito posto pelo Estado (o Estado é a personificação do direito); b) princípio da unicidade: o direito é um sistema único de normas integradas, produzidas para regular os interesses de uma sociedade nacionalmente organizada; c) princípio da positividade: toda a força das normas jurídicas repousa na vontade do próprio Estado enquanto produtor da normas; e d) princípio da racionalidade: proposto inicialmente por Max Weber, consiste na organização da vida por divisão e coordenação das diversas atividades, baseada na dominação legal-racional da lógica do desenvolvimento capitalista. ${ }^{32}$

Graças a sua aliança com o positivismo jurídico, o monismo sobrevive mesmo após o colapso do Estado Liberal e o surgimento do Estado Social (Welfare State). De fato, embora a postura do Estado Social seja diametralmente oposta ao liberalismo econômico do laissez-faire, não há qualquer alteração no centro de positivação da norma jurídica, que continua identificado com a figura estatal. A única diferença em tal centralização é, apenas, a maior ou menor atuação do Estado na limitação da autonomia dos indivíduos.

A partir das décadas de 60 e 70 do século XX, contudo, dissemina-se a ideia de que as regras estatais tendem a ser muito rígidas, com pouco grau de adaptabilidade social - iniciando o período marcado pelo declínio do monismo jurídico. ${ }^{33}$ Nessa época, fenômenos como integração dos mercados mundiais, privatização, globalização e avanço tecnológico foram responsáveis pelo surgimento de novas necessidades humanas - necessidades que o Welfare State mostra-se incapaz de atender, gerando conflitos sociais.

Nas palavras de Wolkmer, o formalismo legal calcado no monismo jurídico esconde as origens sociais e econômicas da estrutura do poder, eternizando a

${ }^{31}$ CARVAlHo, Lucas Borges de. Caminhos (e descaminhos) do pluralismo jurídico no Brasil. In WolKMeR, Antonio Carlos et al. Pluralismo Jurídico: os novos caminhos da contemporaneidade. $2^{\mathrm{a}}$ edição. São Paulo: Saraiva, 2013, p. 15.

${ }_{33}^{32}$ MANNRICH, Nelson. Pluralismo jurídico e Direito do Trabalho..., Op. Cit., p. 8.

${ }^{33}$ Mais uma vez, na expressão utilizada por Mannrich (MANNRICH, Nelson. Pluralismo jurídico e Direito do Trabalho..., Op. Cit., p. 12). 
cultura liberal-individualista dominante ${ }^{34}$ - cenário que não se sustenta em uma sociedade marcada pela pluralidade de quadros sociais, com novos anseios e aspirações. ${ }^{35}$ Em sentido análogo, manifesta-se Nelson Mannrich, para quem a crise do monismo reside no fato de que "suas regras vigentes não só deixam de resolver os problemas emergentes, mas não mais conseguem controlar a convivência social". ${ }^{36}$

Assim, o cenário de insatisfações sociais mostra-se propício à retomada dos valores medievais que a burguesia liberal tanto lutou para minimizar, entre os quais se destacam o corporativismo associativo, o pluralismo social e a descentralização políticoadministrativa. Tais valores, por seu turno, são a chave-mestra para a ascensão das minorias sociais e dos movimentos revolucionários, os quais pretendem a maior socialização do processo de tomada de decisões e produção de leis.

O pluralismo jurídico, então, ressurge como espécie de denúncia à falência das instituições estatais, incapazes de responder às novas demandas sociais e pacificar os conflitos coletivos.

Nesse contexto de insatisfações sociais, ganha espaço a doutrina neoliberal.

Sob o pretexto de estabilizar a economia capitalista, o neoliberalismo representou, em verdade, uma última tentativa de dar fôlego ao Estado centralizador desmoralizado e estremecido por fortes pressões sociais. Em vão, entretanto: as medidas implementadas por referido modelo econômico acabaram por priorizar o atendimento às necessidades de elites financeiras, contribuindo para o aumento das taxas de desemprego e desigualdades sociais ${ }^{37}$ - e, consequentemente, para o surgimento de novos conflitos.

Assim, conforme leciona Antonio Carlos Wolkmer, frente aos inusitados processos de dominação e exclusão produzidos pela globalização, pelo capital financeiro e

\footnotetext{
${ }^{34}$ Wolkmer, Antonio Carlos. Pluralismo Jurídico: fundamentos..., Op. Cit., p. 66.

${ }^{35}$ Para Nicola Matteucci, o liberalismo é desafiado quando a atenção do pensamento político não mais é dirigida ao Estado e suas estruturas, e sim para a sociedade e suas estruturas, com grande autonomia dos subsistemas do sistema político, representados pelos sindicatos, partidos políticos, associações, grupos de pressão, etc. (MAtTeucci, Nicola. Liberalismo. In BobBio, Norberto, MAtTeucci, Nicola e PASQuINO, Gianfranco. Dicionário de Política. 11 a edição. Brasília: Editora Universidade de Brasília, 1998, p. 702).

${ }^{36}$ Mannrich, Nelson. Pluralismo jurídico e Direito do Trabalho..., Op. Cit., p. 12

37 Wolkmer, Antonio Carlos. Pluralismo jurídico: um espaço de resistência... Op. cit., p. 40. Sobre a ineficiência do modelo neoliberal, recomenda-se a leitura de Hobsbawn, para quem o neoliberalistmo baseava-se "num egoísmo associal, na verdade antissocial", marcado por elevadíssimas taxas de desemprego (não meramente cíclico, mas estrutural), enfraquecimento dos sindicatos e crescimento do trabalho informal (Hobsbawn, Eric. Era dos extremos: o breve século XX. 2a edição. São Paulo: Companhia das Letras, 1994, pp. 399-405).
} 
pelo neoliberalismo, ganha relevância reintroduzir politicamente "o poder de ação da comunidade, o retorno dos agentes históricos, o aparecimento inédito de direitos humanos relacionados às minorias e à produção alternativa de acesso à Justiça". ${ }^{38} \mathrm{O}$ pluralismo, então, representa o reconhecimento do Direito à diferença, ou seja, o direito de o indivíduo ser vislumbrado como integrante de certa comunidade cultural, com condições de tomar decisões autônomas. ${ }^{39}$

${ }^{38}$ Wolkmer, Antonio Carlos. Pluralismo jurídico: um espaço de resistência..., Op. cit., p. 38. 39 Cf. Olivé, Leon. Discriminación y Pluralismo. Disponível online em biblio.juridicas.unam.mx/libros/5/2312/9.pdf, acesso em 16.01.2014, às 23h, p. 85. Segundo o autor, a identidade dos indivíduos que pertencem ao grupo se afirma sobre a base das diferenças que os caracterizam como membros do grupo e os distinguem de outros cidadãos. Nesse sentido, "el grupo, sus prácticas, normas, valores y concepciones del mundo son, por una parte, constitutivas de la identidad personal de los individuos, y por la otra son una condición de posibilidad para el ejercicio de la autonomía y la autenticidad de sus miembros" (“o grupo, suas práticas, normas, valores e outras concepções do mundo são, por um lado, constitutivas da identidade pessoal dos indivíduos e, de outros, são uma condição de possibilidade para o exercício da autonomia e a autenticidade de seus membros" - tradução livre) Como exemplos de tais grupos, o autor cita os homossexuais, portadores de doenças que causem estigma social, membros de certas etnias ou raças, etc. 


\subsection{Ressurgimento e reinvenção do pluralismo jurídico}

Consoante já explicitado, a pluralidade de fontes normativas não é fenômeno recente: ao contrário, manifesta-se originariamente no período medieval, quando o direito desenvolvia-se de forma pulverizada, dentro de cada comunidade feudal, com elevada descentralização do poder. ${ }^{40}$

Nesse sentido, a doutrina moderna atribui a Hugo Grotius os primeiros ensinamentos a respeito do pluralismo jurídico. ${ }^{41}$ Referido autor, ao categorizar o Direito com base no centro de sua criação, identificou distintas fontes de positivação de normas jurídicas: direito criado pela comunidade internacional, direito criado pelo Estado e direito proveniente de grupos sociais menores (tal como o decorrente das relações familiares, relações empregatícias e relações entre administradores e administrados). ${ }^{42}$ Indiretamente, assim, estaria Grotius a reconhecer a existência de sistema normativo plural, pautado na soberania de diversos grupos aptos a autorregular suas relações jurídicas e sociais. ${ }^{43}$

O apogeu dos estudos a respeito do pluralismo jurídico, contudo, dá-se com a teoria do direito enquanto instituição, preconizada, inicialmente, por Maurice Hauriou. O conceito de instituição surge com o intuito de superar a ideia de sociedade enquanto mera justaposição de indivíduos autônomos, destacando o papel da coletividade na construção do Direito. ${ }^{44}$

Segundo Hauriou, ${ }^{45}$ um grupo social atinge o status de instituição quando há pleno consenso entre seus membros, evidenciando-se caráter duradouro e contínuo da organização (a despeito das alterações sofridas pela matéria humana que a compõe).

${ }^{40}$ Cf. cap. 1, item 1.2. Também no período colonial podem ser verificados exemplos de sociedades pluralistas, nas quais convivem o direito do Estado colonizador e os direitos tradicionais, bem como em sociedades indígenas não-dizimadas que mantenham seus costumes próprios (para mais informações, cf. SAntos, Boaventura de Souza. O discurso e o poder - ensaio sobre a sociologia da retórica jurídica. Porto Alegre: Sergio Antonio Fabris Editor, 1988, p. 73; HoOKER, M. B. Legal Pluralism: An Introduction to Colonial and Neo-Colonial Laws. Oxford: Clarendor Press, 1965).

${ }^{41}$ A respeito, cf. Martins, Sergio Pinto. O pluralismo do Direito do Trabalho..., Op. Cit., p. 44.

${ }^{42}$ Para mais informações, cf. GROTIUS, Hugo. The rights of war and peace. Disponível online em http://1foll.s3.amazonaws.com/titles/553/0138_Bk.pdf, acesso em 01/12/2014, pp. 17-24.

${ }^{43}$ Segundo Amauri Mascaro Nascimento, além da teoria apresentada por Grócio, o pluralismo jurídico também assenta origens na Teoria dos Corpos Intermediários, preconizada por Montesquieu em $O$ espírito das leis (Nascimento, Amauri Mascaro. Compêndio de Direito Sindical... Op. Cit., p. 188).

${ }^{44}$ DRI, Clarissa Franzoi. Antiformalismo Jurídico: uma Abordagem Institucionalista da Integração Regional. In Cadernos PROLAM/USP, ano 8, vol. 1, 2008, pp. 121-147.

${ }^{45}$ Hauriou, Maurice. A Teoria da Instituição e da Fundação. Porto Alegre: Sergio Antonio Fabris Editor, 2009, pp. 22-24. 
Assim, reconhecendo a multiplicidade dos grupos sociais surgidos no final do século XIX, entende o jurista francês que o Direito é composto por várias instituições, englobando ou até mesmo contrariando o Estado - já que os grupos organizados tendem a melhor defender seus interesses do que o próprio ente estatal.

Situa-se na mesma linha o entendimento de Santi Romano, com pequenas adaptações à teoria de Hauriou. ${ }^{46}$ Romano, identificando os conceitos de “direito" e "instituição", reconhece que o Direito não é necessariamente coligado ao Estado: ao contrário, o fenômeno jurídico existe mesmo fora do Estado, na medida em que há instituições diversas do Estado - como, por exemplo, os partidos políticos, as organizações internacionais, as empresas, etc.

Entretanto, as teorias acima mencionadas, em nenhum momento, cogitam do desaparecimento da figura estatal. Ao contrário: as instituições seriam fontes jurídicas às quais o direito do Estado deve se adequar - razão pela qual não se pode falar em verdadeira "pluralidade de ordenamentos", mas apenas em "pluralidade de fontes", mantendo-se a supremacia estatal. Em outras palavras, como bem ressalta Clarissa Franzoi Dri, o Estado não é simplesmente uma das instituições que compõem a sociedade, mas a "instituição das instituições", que engloba todas as demais, buscando realizar a ordem e a justiça. $^{47}$

Afasta-se, dessa forma, viés puramente anárquico, para se reconhecer a necessidade de interação do Estado com os grupos sociais emergentes. Parte-se tãosomente do pressuposto de que é necessário evitar a sobrevalorização do Estado enquanto único centro produtor da norma jurídica. ${ }^{48}$

No Brasil, o estudo do pluralismo jurídico ganha relevo com o sociólogo português Boaventura de Souza Santos, o qual, na década de 1970, propõe-se a analisar a suposta existência de direito paralelo e alternativo ao estatal em uma favela do Rio de Janeiro (por ele denominado "Direito de Pasárgada"). ${ }^{49}$

\footnotetext{
${ }^{46}$ Romano, Santi. O ordenamento jurídico. Florianópolis: Fundação Boiteux, 2008.

${ }^{47}$ DRI, Clarissa Franzoi. Antiformalismo Jurídico... Op. Cit., p. 129.

${ }^{48}$ Conforme ressalta Luca Giuseppe Pes, somente nas visões mais radicais - e, portanto, menos aceitas pela doutrina moderna -, o Estado é considerado supérfluo no processo de organização social (PES, Luca Giuseppe. Il pluralismo giuridico (2003). Disponível online em http://www.dhdi.free.fr/recherches/theoriedroit/memoires/pesmemoir.pdf, acesso em 17/07/2014, às 22h).

${ }^{49}$ SAnTos, Boaventura de Souza. O discurso e o poder... Op. cit..
} 
O Direito de Pasárgada (também conhecido como "direito dos oprimidos ${ }^{, 50}$ ) é aquele nascido no seio da comunidade, exteriorizado especialmente pela atuação da associação de moradores, e que se contrapõe ao direito estatal por reconhecer a legalidade de fatos sociais rechaçados pelo "direito oficial". Assim, por exemplo, enquanto a disciplina da posse e propriedade na favela revela-se totalmente ilegal para o direito estatal, é amplamente regulamentada pelo direito alternativo - com nítido intuito de pacificação social e resolução de conflitos entre os vizinhos. ${ }^{51}$

Veja-se, entretanto, mais uma vez, que referido direito alternativo não se trata de direito revolucionário, tendente a substituir a ordem jurídica consolidada; ao contrário, refere-se a conjunto de normas que visa a disciplinar as especificidades da comunidade (ainda que "burlando" o direito oficial). ${ }^{52}$ Segundo aponta Boaventura, ocorre relativa apropriação do direito estatal pelo direito de Pasárgada, adaptado mediante aplicação, nas decisões tomadas pela associação, de diversos topoi com carga normativa (como o topos do equilíbrio, o topos da justeza e o topos da cooperação ${ }^{53}$ ), além de provérbios, referências bíblicas, clichés, slogans, índices e sinais. ${ }^{54}$

Ademais, ao contrário do direito estatal, trata-se de manifestação jurídica de cunho eminentemente verbal, com linguagem comum, não profissional. Nem por isso, entretanto, pode-se afirmar que não há qualquer formalismo no direito de Pasárgada. Conforme ressalta o autor, institui-se espécie de formalismo popular, baseado nas fórmulas do direito oficial, mas sem o excessivo apego a elas, que seria demasiado oneroso e afastaria a acessibilidade que caracteriza o direito alternativo. ${ }^{55}$

\footnotetext{
${ }^{50}$ Denominação utilizada pelo autor em SANTOS, Boaventura de Souza. The Law of the oppressed: the construction and reproduction of legality in Pasárgada. In Law and Society Review, vol. 12, n. 1, 1977, pp. $5-126$.

51 Nas palavras de Boaventura de Souza Santos, "a associação de moradores transformou-se, assim, gradualmente, num fórum jurídico, à volta do qual se foi desenvolvendo uma prática e um discurso jurídicos - o direito de Pasárgada". (SANTOS, Boaventura de Souza. O discurso e o poder... Op. cit., p. 14).

${ }^{52}$ A esse respeito, Boaventura de Souza Santos busca resguardar-se contra possíveis críticas atinentes à legitimidade da associação dos moradores para editar normas e solucionar conflitos entre eles ao afirmar que diversos "artefactos" conferem autoridade à associação, como sede própria, máquinas de escrever, carimbos, etc. Tais instrumentos, em seu entender, são necessários para conferir o distanciamento necessário entre a associação e os moradores, garantindo-lhe autoridade para tomada de decisões e edição de normas (SANTOS, Boaventura de Souza. O discurso e o poder... Op. cit., pp. 41-42).

${ }^{53}$ SANTOS, Boaventura de Souza. O discurso e o poder... Op. cit., pp. 19-20.

${ }^{54}$ SANTOS, Boaventura de Souza. O discurso e o poder... Op. cit., pp. 23-24.

${ }^{55}$ SAntos, Boaventura de Souza. O discurso e o poder... Op. cit., p. 32-33. Também a linguagem utilizada, nesse sentido, poderia ser caracterizada como uma linguagem técnica popular, até mesmo por serem utilizadas expressões do direito oficial, como "contratante", "contratado", "benfeitorias", etc. - ainda que com sentido diferente do original.
} 
Da obra de Boaventura, assim, resta claro que o pluralismo jurídico ressurge no século XX não apenas em virtude da resistência à estatização do direito por determinados grupos sociais (que tendem a se autorregular à margem do Estado, com nítido viés revolucionário), mas, sobretudo, da ineficácia do direito estatal em dirimir todas as espécies de conflitos surgidos no seio da sociedade contemporânea, plural e multifacetada. ${ }^{56}$

Aliás, embora o pluralismo jurídico tenha sido inicialmente abafado pelo Estado Liberal, pode-se afirmar, em última análise, que esse modelo de Estado foi ele próprio responsável pelo surgimento de tais manifestações jurídicas plurais, ao reconhecer autonomia jurídica aos indivíduos, mediante a liberdade contratual. Dessa liberdade, surgem novos e diversos fatores de coordenação coletiva dos grupos sociais, gerando espírito de solidariedade social - o qual, naturalmente, leva à necessidade de autocomposição de conflitos. ${ }^{57}$ Tal espírito ganha relevo com o Estado Social, quando a liberdade contratual passa a encontrar barreiras em nome do interesse coletivo e da segurança da comunidade.

Além de Boaventura de Souza Santos, outros sociólogos e filósofos do Direito dedicaram-se, nas últimas décadas do século XX, ao estudo do pluralismo jurídico, inclusive para apresentar novas "formas" de pluralismo, adaptadas à realidade multicultural do século XXI. Segundo Norberto Bobbio, por exemplo, o pluralismo

\footnotetext{
56 Atualmente, diversas críticas são desferidas à obra de Boaventura. Em primeiro lugar, esta é criticada porque, supostamente, faltaria originalidade ao direito de Pasárgada, já que este, por fazer parte da ordem capitalista, estaria contaminado pelos mesmos valores mercantis ínsitos a tal modelo. Ademais, questiona-se se o "direito dos oprimidos" pode ser reconhecido como verdadeiro sistema jurídico, pois, muitas vezes, marcado pela violência e autoritarismo. Nesse sentido, conforme afirma Lucas Borges de Carvalho, "o maniqueísmo direito positivo burguês / direito alternativo dos oprimidos (...) vale como discurso para agradar auditórios, mas, na prática, não ajuda a enfrentar os problemas que realmente afligem as classes subalternas do país" (CARVAlHO, Lucas Borges de. Caminhos (e descaminhos) do pluralismo jurídico no Brasil... Op. cit., p. 21). Para maiores informações sobre as críticas desferidas à obra de Boaventura, cf. CARVALHO, Lucas Borges de. Caminhos (e descaminhos) do pluralismo jurídico no Brasil... Op. cit.. Após tais críticas, o próprio Boaventura de Souza Santos propõe-se a revisar a teoria do pluralismo jurídico antes desenvolvida, afirmando que a pluralidade de ordens jurídicas não implica a perda de centralidade do direito estatal entretanto, a existência de direitos paralelos tende a conferir caráter mais democrático ao direito oficial (cf. SAntos, Boaventura de Souza. Crítica de la Razón Indolente... Op. Cit.)

57 A esse respeito, Wolkmer faz menção, inclusive, a um pluralismo jurídico surgido no seio da própria burguesia liberal, contrária ao liberalismo e ao poder absoluto do soberano. Entretanto, o atual pluralismo jurídico é diverso daquele produzido pela democracia liberal-burguesa, que era elitista, privilegiando intentos de setores específicos e minorias com poder de decisão, em detrimento de prioridades da vida em sociedade. Hoje, o pluralismo é aberto, descentralizado e democrático, preocupando-se com a práxis da vida cotidiana, com as injustiças sofridas por determinadas classes. Objetivo do atual modelo é conter os conflitos de classes e erradicar as formas de opressão (e não, apenas, satisfazer interesses desejados), sendo, por tal razão, chamado por Wolkmer de "Direito Comunitário" (Wolkmer, Antonio Carlos. Pluralismo jurídico: um espaço de resistência..., Op. cit., p. XX).
} 
jurídico percorreu duas fases distintas. ${ }^{58}$ A primeira corresponde ao nascimento e ao desenvolvimento do historicismo jurídico, que afirma a nacionalidade dos direitos emanados direta ou indiretamente da consciência popular. Assim, ao lado do direito natural único, comum a todos os povos, encontram-se tantos direitos quantos forem os povos ou nações.

Nessa fase, como se vê, o pluralismo adquire caráter "estatalista": o direito universal fraciona-se no direito de cada nação. Referida fase mantém estreita relação com o positivismo jurídico, na medida em que cada direito constitui um direito autônomo, advindo de uma vontade soberana - por tal razão, Bobbio utiliza a denominação "pluralismo estatal" para caracterizá-la. ${ }^{59}$

Já a segunda fase, denominada “institucional”, corresponderia ao pluralismo em seu conceito pleno, pois significa não apenas que "há muitos ordenamentos jurídicos (mas todos do mesmo tipo), em contraposição ao Direito universal único, mas que há ordenamentos jurídicos de muitos e variados tipos." 60 É institucional porque existe um ordenamento jurídico sempre que há uma instituição, ou seja, um grupo social organizado, originado por correntes ideológicas antiestatais. ${ }^{61}$

O pluralismo estatal difere do institucional em virtude dos conflitos por este criados: enquanto o segundo envolve o problema do relacionamento entre ordenamentos estatais, o primeiro envolve conflitos entre ordenamentos estatais e nãoestatais.

Bobbio reconhece o mérito da teoria institucionalista (especialmente por compreender que o direito não se restringe a normas estatais), mas prefere utilizar a teoria normativa para justificar a existência do pluralismo jurídico. Com efeito, segundo o

\footnotetext{
${ }^{58}$ BobBio, Norberto. Teoria do Ordenamento Jurídico. 6 a edição. Brasília: UnB, 1995, p. 161 e ss.

${ }^{59}$ Veja-se que, a rigor, referida fase pluralista apontada por Bobbio pouco se diferencia do sistema monista (o qual, como visto, encontra seu apogeu com o positivismo jurídico). Portanto, com a devida vênia, entende-se que o sistema narrado por Bobbio não se insere efetivamente no conceito de pluralismo, sendo apenas um desdobramento lógico do próprio monismo, i.e., da concepção de que apenas o direito estatal é válido e aplicável na sociedade. Com efeito, embora exista pluralidade de ordenamentos, esta é inerente à pluralidade de Estados - e não se pode falar em verdadeiro pluralismo, pois não há interação entre tais ordenamentos, cada qual sendo plena e integralmente aplicado no Estado onde se desenvolve. Somente existe pluralismo quando, ao lado do direito estatal, emergem sistemas jurídicos alternativos, aplicáveis concomitantemente ao primeiro.

${ }^{60}$ BobBio, Norberto. Teoria do Ordenamento Jurídico.... Op. Cit., p. 163.

${ }^{61}$ Segundo Bobbio, distinguem-se quarto tipos de ordenamentos não-estatais: a) ordenamentos acima do Estado (como, e.g., o ordenamento internacional); b) ordenamentos abaixo do Estado (ordenamentos sociais - como, e.g., os sindicatos); c) ordenamentos ao lado do Estado (como o da Igreja Católica, para alguns Estados); e d) ordenamentos contra o Estado (como organizações terroristas, seitas secretas, etc.). (BOBBIO, Norberto. Teoria do Ordenamento Jurídico.... Op. Cit., p. 164)
} 
institucionalismo de Santi Romano ${ }^{62}$, a organização vem antes da criação de normas. Para Bobbio, tal assertiva não é verdadeira, já que são necessárias normas para que a organização possa se estruturar. Portanto, as normas vêm antes da organização e a “produção de normas é sempre o fenômeno originário, ainda que não exclusivo, para a constituição de uma instituição". ${ }^{63}$

No Brasil, Miguel Reale defende a existência de Direito também em outros grupos ou instituições que não o Estado (como, por exemplo, no seio da Igreja ou das organizações desportivas). Porém, como apenas o Estado detém o poder de aplicar sanções com característica de universalidade, pode ser considerado o ordenamento jurídico soberano, ao qual recorrem os demais para dirimir conflitos. ${ }^{64}$ Vê-se, assim, que a teoria defendida pelo autor em muito se assemelha à concepção original dos institucionalistas, os quais, como visto, compreendem o Estado como a "instituição das instituições".

Por seu turno, Tercio Sampaio Ferraz Junior, ao analisar os critérios de determinação da justiça, também demonstra - ainda que indiretamente - a diferenciação entre as sociedades pautadas no monismo e no pluralismo jurídico. ${ }^{65}$

Em seu entender, duas são as espécies de justiça: a formal e a material. A justiça formal é o valor ético-social positivo segundo o qual se atribui a cada pessoa aquilo que lhe é devido. Trata-se da discussão racional dos problemas do relacionamento social, baseada na igualdade como proporção aritmética e geométrica e, consequentemente, em um critério unívoco de distribuição de bens. Já a justiça material corresponde ao conteúdo concreto da justiça formal, à determinação de critérios para especificar aquilo que é devido e a quem. Porém, tais critérios não são unívocos, e sim formulados com base em concepções metafísicas - daí por que há grande dificuldade em determinar o justo concreto. $^{66}$

A filosofia de Ferraz Junior é baseada na existência de códigos de transmissão e recepção de mensagens - os quais podem ser aplicados à comunicação de normas jurídicas. Nesse sentido, considera o autor que a justiça, tanto em seu aspecto material quanto formal, é um código de comunicação normativa. Nada obstante, em

\footnotetext{
${ }^{62}$ RomAnO, Santi. O ordenamento jurídico... Op. Cit., pp. 182-185.

${ }^{63}$ BobBio, Norberto. Teoria Geral do Direito... Op. Cit., p 16.

${ }^{64}$ REALE, Miguel. Lições Preliminares de Direito. $27^{\mathrm{a}}$ edição. São Paulo: Saraiva, 2012, pp. 77-80.

${ }^{65}$ Para melhor compreensão do tema, v. FERRAZ JUNIOR, Tercio Sampaio. Justiça material como um código fraco na comunicação normativa. In Estudos de Filosofia do Direito. $2^{\text {a }}$ Ed. São Paulo: Atlas, 2009, pp. 249-262.

${ }^{66}$ FerRaZ JUnIOR, Tercio Sampaio. Justiça material como um código fraco... Op. Cit., pp. 249-251.
} 
virtude das características acima descritas, a justiça formal é um código forte na comunicação normativa, enquanto a justiça material é um código fraco, por não permitir um sentido unívoco de interpretação. ${ }^{67}$

Aplicando-se tal entendimento à realidade das relações sociais é que se extrai sua interação com a doutrina do monismo e pluralismo jurídicos: nas sociedades em que prevalece o código forte da justiça formal (denominadas sociedades de competição e cooperação), exigem-se normas jurídicas únicas e unívocas, para que seus membros associem forças na consecução de um fim comum; nas sociedades dominadas pela justiça material (denominadas sociedades de presteza e rivalidade), ao contrário, não há busca por um fim comum, mas sim pela prevalência de interesses de cada grupo social (evidenciado pela família, amigos, etc.) - razão pela qual é admitida a existência de normas provenientes de diversas fontes. Nas palavras do autor, enquanto nas sociedades cooperativas, a Administração pública e encargos de direção e governo são meios funcionais para a obtenção dos fins da justiça, nas sociedades de rivalidade, o "personalismo afetivo" dificulta possíveis acordos coletivos duráveis, e a justiça é marcada pela prevalência da equidade. $^{68}$

Todavia, entre os autores que buscam aprimorar os conceitos de pluralismo jurídico tradicionalmente apresentados pela doutrina, certamente merece lugar de destaque o já citado Antonio Carlos Wolkmer, o qual propõe a existência de um pluralismo progressista e emancipatório, por ele denominado “comunitário-participativo".

Consoante Wolkmer, nem toda regulação comunitária e autônoma é justa e legítima - cumpre distinguir os grupos sociais comprometidos com o bem comum daqueles apenas preocupados com a manutenção de privilégios e oposição a qualquer mudança (os quais representariam pluralismo "conservador e reacionário"). ${ }^{69}$ Para tanto, o autor elenca determinados critérios/fundamentos que seriam aptos a diferenciar o verdadeiro pluralismo dessas manifestações que intentam, tão-somente, manter o status quo ante - os quais seriam especialmente aplicáveis à realidade da América Latina. ${ }^{70}$

\footnotetext{
${ }^{67}$ FerRaz JUnIOR, Tercio Sampaio. Justiça material como um código fraco... Op. Cit., p. 254.

${ }^{68}$ FerraZ Junior, Tercio Sampaio. Justiça material como um código fraco... Op. Cit., pp. 257-260.

${ }^{69}$ WolKMer, Antonio Carlos. Pluralismo Jurídico... Op. Cit., p. 232.

${ }^{70}$ Veja-se, nesse sentido, que a proposta de Wolkmer difere da de Boaventura, pois o último não se preocupa em distinguir o pluralismo conservador do reacionário, aceitando qualquer prática alternativa como exemplo de pluralismo.
} 
Inicialmente, destaca fundamentos de efetividade material (relacionados ao conteúdo e aos elementos constitutivos do projeto cultural pluralista), quais sejam: novos sujeitos coletivos e necessidades humanas fundamentais. ${ }^{71}$

Os novos sujeitos coletivos são "novos" porque se contrapõem ao oficial, ao estabelecido, e "coletivos" porque priorizam uma pluralidade de sujeitos, exteriorizados pelos novos movimentos sociais. Em contraposição ao "antigo sujeito histórico individualista", eles representam a retomada e ampliação do conceito de "sujeito", fortemente associado a uma tradição de lutas e resistências e evidenciado pela figura do proletariado, das massas trabalhadoras, dos "marginalizados" da sociedade industrial - hoje, ampliando-se para abarcar quaisquer minorias atingidas pela miséria e pela pobreza (e.g., indígenas, mulheres, menores, etc.). ${ }^{72}$

As necessidades humanas fundamentais, por seu turno, advêm do próprio surgimento dos novos sujeitos coletivos, e representam a falta ou privação de objetos determinados (bens materiais decorrentes da produção humana em sociedade) ou a ausência de algo imaterial relacionado ao desejo. Trata-se, em outras palavras, da ausência das necessidades mínimas que garantam as condições materiais e culturais de uma vida boa e digna e assegurem condições justas e iguais de existência. ${ }^{73}$

Além de fundamentos de efetividade material, Wolkmer sustenta a necessidade de critérios de efetividade formal para o desenvolvimento do real pluralismo comunitário-participativo (vinculados à ordenação prático-procedimental): reordenação do espaço político, ética concreta da alteridade e racionalidade emancipatória. ${ }^{74}$

A reordenação do espaço político demanda maior participação dos novos sujeitos coletivos na esfera política. A estrutura política brasileira sempre foi marcada pela centralização, sufocando (até mesmo involuntariamente) quaisquer manifestações locais e descentralizadas de poder. Nesse sentido, conforme Wolkmer, é necessário retomar o conceito de "comunidade", o qual - ainda que impreciso - envolve certo aglomerado social com características singulares, interesses comuns e identidades

\footnotetext{
${ }^{71}$ Wolkmer, Antonio Carlos. Pluralismo Jurídico... Op. Cit., p. 233 e ss.

${ }^{72}$ Wolkmer, Antonio Carlos. Pluralismo Jurídico... Op. Cit., pp. 235-241.

${ }^{73}$ Wolkmer, Antonio Carlos. Pluralismo Jurídico... Op. Cit., pp. 241-248.

${ }^{74}$ Wolkmer, Antonio Carlos. Pluralismo Jurídico... Op. Cit., p. 248 e ss.
} 
próprias que, embora inseridos num espectro de relações pulverizadas, interligam-se por ideologias comuns e necessidades fundamentais. ${ }^{75}$

Segundo Wolkmer, referida participação social nas decisões políticas não se basta no mecanismo da delegação, mas importa efetivo controle democrático do Estado por sujeitos individuais coletivos capazes de ação e decisão. Instrumentos como iniciativa legislativa vinculante, veto popular, audiências públicas, revogação de mandato de governantes, voto distrital, conselhos populares, são essenciais para o êxito deste fundamento de ordem formal. ${ }^{76}$

A ética concreta da alteridade corresponde a nova categoria de valores éticos proposta por Wolkmer, fruto da combinação de princípios universais com valores próprios e peculiares da "sociedade capitalista periférica", ou seja, das populações oprimidas, excluídas e marginalizadas. ${ }^{77}$

Referido conceito, assim, decorre da crise do ethos valorativo vivenciada pelas sociedade contemporânea de massa, marcada pelo individualismo racionalista e pela ausência de padrões comunitários e democráticos. O ponto de partida para sua construção é a teoria da racionalidade comunicativa de $\operatorname{Habermas}^{78}$, segundo a qual é necessário construir valores éticos universais a partir da análise da ação concreta do indivíduo fundada em três grandes princípios: justiça, solidariedade e bem-comum. Para o autor alemão, não mais se justifica uma ética pautada no interesse de pequenos grupos ou comunidades - deve ser buscada a ética da comunidade ideal, baseada em valores universais necessários à consecução do bem-estar geral.

Wolkmer, entretanto, ressalta a dificuldade de operacionalizar-se a teoria de Habermas na atual sociedade capitalista, repleta de comunidades periféricas, totalmente alijadas do poder central. ${ }^{79}$ Com efeito, a construção de valores universais só é possível em uma sociedade ideal, em que não há conflitos e os indivíduos movimentam-se em conjunto, sempre visando a um bem comum. A ética proposta pelo autor alemão, de fato,

\footnotetext{
${ }^{75}$ Wolkmer, Antonio Carlos. Pluralismo Jurídico... Op. Cit., pp. 248-261.

${ }^{76}$ Wolkmer, Antonio Carlos. Pluralismo Jurídico... Op. Cit., pp. 255-256.

${ }^{77}$ Wolkmer, Antonio Carlos. Pluralismo Jurídico... Op. Cit., pp. 261-273.

${ }^{78}$ Cf. HABERMAS, Jürgen. Direito e democracia - entre facticidade e validade. Vol. II. Rio de Janeiro: Tempo Brasileiro, 1997, pp. 99 e ss. Segundo o autor alemão, na linha do quanto exposto acima, o poder comunicativo da sociedade civil moderna é exercido, sobretudo, por organizações, movimentos e associações que "captam os ecos dos problemas sociais que ressoam nas esferas privadas, condensam-nos e os transmitem, a seguir, para a esfera pública política" (HABERMAS, Jürgen. Direito e democracia..., Op. Cit., p. 99).

${ }^{79}$ Wolkmer, Antonio Carlos. Pluralismo Jurídico... Op. Cit., pp. 280-281.
} 
tende a desconsiderar as aspirações do "outro", i.e., do indivíduo sem voz na tomada de decisões pelo poder central, alijado da sociedade para a qual os valores supostamente universais teriam sido construídos.

Por isso, Wolkmer pugna por um avanço na ética discursiva proposta por Habermas para uma ética concreta da alteridade, expressa pelos valores culturais da sociedade periférica, do "outro" (daí a utilização da expressão "alteridade”). Essa ética parte de valores a priori universais, mas não se prende a eles porque traduz concepções valorativas que emergem das próprias necessidades dos sujeitos individuais e coletivos em permanente afirmação - trata-se de ética com cunho libertário e pedagógico, pois se adapta aos intentos de emancipação dos povos oprimidos, priorizando práticas peculiares de uma certa sociedade, de forma material e não-formal. Por tal razão, propicia uma prática libertadora, capaz de emancipar os sujeitos históricos oprimidos e excluídos. ${ }^{80}$

Ademais, a ética da alteridade inspira-se na práxis concreta e na situação histórica das classes marginalizadas e, por isso, além de contemplar princípios racionais universalizantes (vida, liberdade, bem-comum), é marcada por valores específicos representados pela emancipação, autonomia individual e coletiva, solidariedade, justiça e satisfação das necessidades humanas.

Finalmente, passa-se à análise da racionalidade emancipatória. A racionalidade, surgida como consequência do ideal liberal-burguês, desencadeou progresso material, mas acabou por afetar a liberdade do homem, gerando alienação e massificação. Enquanto Weber aponta os aspectos positivos da racionalização (o "desencantamento" do mundo, gerado pela superação das tradições míticas e mágicas que marcaram o mundo primitivo), a crítica marxista destaca seus pontos negativos (alienação, coisificação e dominação).

Nesse contexto de críticas, surge a Escola de Frankfurt, propondo-se a reconstruir a racionalidade moderna, mas sem negar a razão, mediante a teoria da razão comunicativa. Para os adeptos dessa escola (sobretudo, Jürgen Habermas e Karl-Otto Apel), atualmente, o capitalismo utiliza-se da razão como forma de opressão - ainda que tal razão seja exercida de forma mascarada, gerando uma fusão peculiar entre a racionalidade e a técnica da dominação. A única forma de combater essa fusão, assim, seria mediante vigorosa ação comunicativa - a razão não mais se encontraria adstrita ao

\footnotetext{
${ }^{80}$ WOLKMER, Antonio Carlos. Pluralismo Jurídico... Op. Cit., pp. 282-283.
} 
indivíduo, mas partiria de um consenso entre dois ou mais sujeitos a respeito de questões relacionadas com a verdade e a justiça. Tais conceitos seriam, nesse sentido, queridos e aceitos por todos.

Wolkmer - embora reconhecendo o ineditismo e a importância da teoria propugnada pela escola alemã - questiona sua efetiva aplicabilidade a países da América Latina (os quais, conforme acima ressaltado, são o objeto primordial de seus estudos), onde os sujeitos individuais e coletivos vivenciam história de opressões e exclusões. Assim, afirma que a razão comunicativa somente teria espaço em países desenvolvidos, nos quais há atores livres, autônomos e iguais - diferentemente da realidade dos países em desenvolvimento. Realmente, como obter consenso em sociedades marcadas por profundas desigualdades e contextos culturais fragmentados (quando tal consenso não é forjado pelo próprio Estado)? ${ }^{81}$

Referido consenso somente pode ser obtido mediante análise das práticas sociais cotidianas, que refletem as reais necessidades dos sujeitos envolvidos. A racionalidade, nesse contexto, deve abandonar qualquer visão metafísica e transcendental para basear-se na experiência concreta e pluralidade de formas da vida cotidiana evoluindo, então, para uma racionalidade emancipatória.

A razão emancipatória, assim, não se confunde com uma razão operacional, pré-determinada, mas parte das necessidades históricas da comunidade. A racionalidade surge como "expressão da identidade cultural enquanto exigência e afirmação da liberdade, emancipação e autodeterminação" da cultura periférica. ${ }^{82}$

No entender de Wolkmer, portanto, somente se atingidos todos esses fundamentos de ordem material e formal é que se verificará pluralismo progressista e emancipatório - diferentemente daquele constatado por Boaventura em Pasárgada, dissociado de inspirações revolucionárias e amplamente influenciado pelas próprias regras estatais.

Veja-se que, em nenhum momento, o pluralismo jurídico de Wolkmer pretende minimizar ou suprimir o Direito Estatal; ao contrário, este é considerado um

\footnotetext{
${ }^{81}$ Wolkmer, Antonio Carlos. Pluralismo Jurídico... Op. Cit., p. 280.

${ }^{82}$ Wolkmer, Antonio Carlos. Pluralismo Jurídico... Op. Cit., p. 282. Mais uma vez, aproximando-se do pressuposto teórico fundamental das teorias precursoras do pluralismo jurídico.
} 
Direito necessário (porém, não suficiente), e se insere no próprio conceito de pluralismo jurídico por representar uma das muitas formas jurídicas que podem existir na sociedade. ${ }^{83}$

Nesse contexto, a superação do monismo jurídico pelo pluralismo - em qualquer de suas formas - pode ser vislumbrada em duas estratégias distintas. Inicialmente, práticas alternativas surgidas no bojo do próprio Estado demonstram a superação do sistema centralizador da produção normativa, destacando-se os mecanismos de democracia direta assegurados na Constituição, as ações judiciais coletivas, as convenções coletivas de trabalho, etc. Em segundo lugar, o pluralismo surgido na esfera não estatal (que representaria o verdadeiro pluralismo jurídico participativo-comunitário, na acepção de Wolkmer).

Por óbvio, a teoria de Wolkmer também recebeu um sem-número de críticas. ${ }^{84}$ Entretanto, em virtude da completude do argumento proposto pelo autor, esta será utilizada na presente tese para defesa do argumento pretendido.

\footnotetext{
${ }^{83}$ A respeito, cf. RUBIO, David Sánchez. Pluralismo jurídico e emancipação social. In WOLKMER, Antonio Carlos et al. Pluralismo Jurídico: os novos caminhos da contemporaneidade. $2^{\text {a }}$ edição. São Paulo: Saraiva, 2013, p. 59.

${ }^{84}$ Para maiores informações sobre referidas críticas, cf. CARVALHO, Lucas Borges de. Caminhos (e descaminhos) do pluralismo jurídico no Brasil... Op. Cit., pp. 30 e ss.
} 


\subsection{Pluralismo jurídico e desenvolvimento do Direito do Trabalho}

Esmiuçadas as teorias que buscam justificar a prevalência do pluralismo jurídico diante do monopólio estatal de produção normativa, deve-se questionar: qual o papel da pluralidade no Direito do Trabalho, em especial no que tange às fontes desse tão peculiar ramo da ciência jurídica?

Inicialmente, entretanto, deve-se ter cautela na diferenciação entre "pluralismo jurídico" e simples "pluralismo do Direito do Trabalho". Com efeito, enquanto pluralismo jurídico refere-se à multiplicidade de fontes normativas das relações trabalhistas, pluralismo do Direito do Trabalho envolve as diversas espécies de relações laborais compreendidas no conceito de trabalho subordinado (relações de trabalho na empresa, relações de trabalho no domicílio, relações de trabalho rural, relações de trabalho doméstico, relações de trabalho especiais, relações de trabalho a termo, etc.). ${ }^{85}$

Segundo Amauri Mascaro Nascimento, o Direito do Trabalho é expressão máxima do pluralismo jurídico, na medida em que leis promulgadas pelo Estado combinam-se com contratos coletivos pactuados entre sindicatos e entidades patronais, evidenciando "um direito estatal e um direito profissional convivendo, formando um complexo de normas jurídicas que se combinam segundo uma hierarquia própria de aplicação, basicamente apoiada (...) no princípio da norma mais favorável, salvo exceções". 86

Com efeito, é lugar-comum na doutrina trabalhista a afirmação de que o pluralismo jurídico teria encontrado, no Direito do Trabalho, sua maior fonte de aplicação. ${ }^{87}$ Todavia, referida afirmação - sobretudo no que concerne à experiência brasileira - talvez merecesse estudo mais aprofundado, especialmente diante dos conceitos modernos de pluralismo jurídico, tratados no capítulo anterior.

Antecipando-se a eventuais críticas, deve-se ressaltar: não se está, aqui, questionando a importância do pluralismo jurídico para o Direito do Trabalho, mas tão-

${ }^{85}$ Para mais informações a respeito do tema, recomenda-se a leitura de CARVALHO, António Nunes. $O$ pluralismo do Direito do Trabalho. In III Congresso Nacional de Direito do Trabalho. Coimbra: Almedina, 2000, pp. 269-294.

${ }^{86}$ NASCIMENTO, Amauri Mascaro. Iniciação ao Direito do Trabalho. 39a Ed. São Paulo: LTr, 2014, p. 87.

${ }^{87}$ Além de Amauri Mascaro Nascimento, cf. SILva, Otavio Pinto e. Fontes do direito do trabalho. In Revista da Faculdade de Direito da Universidade de São Paulo - FDUSP, vol. 96, 2001, pp. 203-214; MARTins, Sergio Pinto. O pluralismo do Direito do Trabalho..., Op. Cit.; etc. 
somente se propondo uma releitura de sua aplicação a este ramo do Direito, de acordo com as teorias mais modernas a respeito do tema.

As primeiras normas trabalhistas aparecem como resposta à realidade da classe operária do final do século XIX, especialmente após a eclosão da Revolução Industrial e a erosão do modelo do liberalismo econômico. ${ }^{88}$ Como ressalta Alfredo Montoya Melgar, a legislação trabalhista, enquanto sistema social, nasce diante dos problemas socioeconômicos decorrentes da Revolução Industrial; portanto, antes da sociedade industrial, falta o pressuposto histórico que daria lugar ao surgimento do Direito do Trabalho: a "generalización del trabajo voluntario, dependiente y por cuenta ajena, como factor fundamental de los procesos de producción". ${ }^{89}$

Referida generalização, entretanto, toma contornos extremos quando considerados os dogmas do liberalismo econômico em que se assenta a Revolução Industrial. Proprietário de sua força de trabalho, o trabalhador tem ampla e irrestrita liberdade na contratação de seus serviços, diante da plena igualdade de condições na relação firmada entre ele e seu empregador. ${ }^{90}$ Daqui, advêm as conhecidas condições de trabalho extremamente desumanas impostas à classe operária: fixação de períodos de trabalho assaz dilatados (por vezes em contratos vitalícios), descaso patronal em relação a políticas de segurança e higiene no ambiente laboral, elevado número de acidentes do trabalho, constante recurso à mão de obra infantil, baixíssimos salários, entre outros ${ }^{91}$ simultaneamente ao surgimento das primeiras manifestações de trabalhadores, que se organizavam em entidades clandestinas.

\footnotetext{
${ }^{88}$ Para estudo detalhado da história do Direito do Trabalho, cf., além das obras a seguir citadas, MORAES Filho, Evaristo de. Introdução ao Direito do Trabalho. Vol. I. Rio de Janeiro: Forense, 1956; AlONSO OlEA, Manuel. Introdução ao Direito do Trabalho. $4^{\text {a }}$ Ed.. São Paulo: LTr, 1984; ViAnNA, Francisco José de Oliveira. Problemas de Direito Sindical. Rio de Janeiro: Max Limonad, 1943; RomaGnOLI, Umberto. Weimar, ¿y después?. In Colección estructuras y procesos - Serie 1º de Mayo. Madrid: Trota, 1992.

89 "generalização do trabalho voluntário, dependente e por conta alheia, como fator fundamental dos processos de produção" - tradução livre (MONTOYA MElgar, Alfredo. Derecho del trabajo. 29a Ed.. Madrid: Editorial Tecnos, 2008, p. 51).

${ }^{90}$ É o que se extrai do Código Civil Napoleônico de 1804, o qual, após regular o contrato de trabalho como espécie de locação, estabeleceu, em seu art. 1134 que "as convenções têm força de lei para os que a celebrarem". Segundo narra Alice Monteiro de Barros, "influenciados por esses dispositivos legais, os códigos elaborados no século XIX e no início do século XX, como o Código Civil Argentino, o Espanhol e o nosso, de 1916, seguiram a diretriz já traçada, e inseriram o serviço humano nos moldes clássicos, ou seja, ao lado da locação de coisas ou de animais" (BArros, Alice Monteiro de. Curso de Direito do Trabalho. $9^{\text {a }}$ Ed.. São Paulo: LTr, 2013, p. 63).

91 Para análise detida das condições desumanas a que eram submetidos os trabalhadores à época do liberalismo econômico, cf. Montoya Melgar, Alfredo. Derecho del trabajo. 29a Ed. Madri, Tecnos, 2008, pp. 65 e ss.
} 
Entretanto, repita-se: eventuais organizações de trabalhadores atuavam de forma clandestina, na medida em que o Estado liberal não admitia a formação de instituições intermediárias entre o Estado e o indivíduo. ${ }^{92}$

Nesse momento, diante dos anseios das próprias classes sociais, ganha relevo a atuação do Estado enquanto agente produtor de normas jurídicas. Em diversos países, começam a aparecer - embora esparsas - leis de cunho trabalhista, assentando as bases "de um direito que iria avassalar todos os demais, derrogando princípios que pareciam estruturados na própria história da humanidade". ${ }^{93}$ Trata-se do Estado Social ou Estado de Providência, o primeiro a rechaçar os dogmas da sociedade liberal e reconhecer a necessidade de tratar os desiguais de forma desigual.

Embora o Estado Social seja fruto direto das manifestações operárias que ganharam corpo na Revolução Industrial, é certo que este também consagra a supremacia da norma estatal, da visão do Estado enquanto única fonte de direito. Sua diferença em relação ao Estado Liberal, conforme bem observa Nelson Mannrich, está na maior ou menor intervenção estatal nas relações privadas, diante da maior ou menor esfera de autonomia dos indivíduos. ${ }^{94}$ Porém, não há qualquer rompimento com o sistema monista predominante até então; ao contrário, verifica-se exacerbação de tal sistema, na medida em que o Estado se sente pressionado para regulamentar, minuciosamente, todas as questões sociais que possam ocasionar seu declínio por falta de apoio popular.

O monismo estatal atinge seu ápice com o corporativismo: centrado no poder único do governante, referido modelo rechaçava quaisquer forças sociais alheias ao Estado. Por tal razão, seu objetivo primordial foi o de diminuir essas forças, por meio da imposição de sua submissão ao Estado, mascarada em suposto regime de colaboração dos sindicatos com as instituições estatais. Não por outra razão, assim, atribui-se ao sindicato natureza jurídica de pessoa de direito público, financiada e organizada pelo Estado, e

\footnotetext{
${ }^{92}$ Segundo Giuseppe Santoro-Passarelli, o Estado, em particular, "ostacolava il sindacalismo nascente dei lavoratori, per il convincimento diffuso che esso si risolvesse in un inammissibile attentato alla libertà di industria e di commercio e al principio allora intoccabile della libertà negoziale". ("obstaculizava o sindicalismo nascente dos trabalhadores, pelo convencimento difuso de que esse se resolvia em um inadmissível atentado à liberdade de indústria e comércio e ao princípio então intocável da liberdade negocial" - tradução livre) (SANTORO-PASSARELLI, Giuseppe. Dirito Sindacale. Bari: Laterza, 2007, p. 9).

${ }^{93}$ VIANNA, Segadas. Antecedentes históricos. In SÜSSEKIND, Arnaldo et al. Instituições de direito do trabalho. Vol. 1. 22 ad.. São Paulo, LTr, 2005, p. 41.

${ }^{94}$ Mannrich, Nelson. Pluralismo juridico... Op. Cit., p. 13.
} 
confere-se à Justiça do Trabalho plena capacidade de dirimir conflitos sociais, inclusive coletivos. $^{95}$

Todavia, conforme ressalta Amauri Mascaro Nascimento, a centralização do poder no Estado corporativo foi, ela própria, o arcabouço político à superação do monismo jurídico e ao reconhecimento da autonomia privada coletiva, na medida em que referida forma de Estado suscitou questionamentos sobre a efetiva legitimidade do Direito do Trabalho que não advém da própria sociedade, i.e., dos grupos econômicos e profissionais. $^{96}$

De fato, a atuação estatal - embora intensa - mostrou-se insuficiente para atender, de forma eficaz, a todas as necessidades dos trabalhadores: em primeiro lugar, em virtude da lentidão e excesso de formalismo do processo legislativo oficial; em segundo, diante da dificuldade do Estado em conhecer, minuciosamente, todas as necessidades da classe operária. Somem-se a tais fatores as profundas transformações sofridas pelo mercado de trabalho e de capital: a automação das fábricas, a maior especialização exigida dos trabalhadores e das empresas, o surgimento de formas alternativas de contratação todos foram determinantes para a crise do modelo preponderantemente estatal e consequente surgimento de novas manifestações sociais. Assim, embora ainda dominante a atuação do Estado, esta não consegue abafar a voz dos corpos sociais coletivos, que anseiam pela ampliação de sua capacidade legislativa.

Segundo Nelson Mannrich, diante das grandes transformações ocorridas no cenário econômico, "busca-se não apenas o alargamento dos instrumentos de controle tradicionais, como também a criação de novos instrumentos, refletida na explosão de

\footnotetext{
95 Destacam-se trechos, a esse respeito, da célebre Carta del Lavoro, de 1927: “III. L'organizzazione sindacale o professionale è libera. Ma solo il sindacato legalmente riconosciuto e sottoposto al contollo dello Stato, ha il diritto di rappresentare legalmente tutta la categoria (...); di stipulare contratti collettivi di lavoro obbligatori per tutti gli appartenenti alla categoria; di imporre loro contributi (...)" ("a organização sindical ou profissional é livre. Mas só o sindicato legalmente reconhecido e submetido ao controle do Estado tem o direito de representar legalmente toda a categoria (...); de estipular contratos coletivos de trabalho obrigatórios a todos os pertencentes à categoria; de impor suas contribuições" - tradução livre); " $I V$. La Magistratura del lavoro è l'organo con cui lo Stato interviene a regolare le controversie del lavoro, sia che vertano sull'osservanza dei patti e delle altre norme esistenti, sia vertano sulla determinazione di nuove condizioni del lavoro”; “ $V$. (...) In virtù di questa integrale rappresentanza, essendo gli interessi della produzione interessi nazionale, le corporazioni sono dalla legge riconosciute come organi di Stato" (a Magistratura do trabalho é o órgão com o qual o Estado intervém a regular as controvérsias de trabalho, seja as que versem sobre a observância dos pactos e outras normas existentes, seja as que versam sobre determinações de novas condições de trabalho; (...) em virtude dessa integral representação, sendo os interesses da produção interesses nacionais, as corporações são, por lei, reconhecidas como órgãos do Estado - tradução livre) (grifo no original).

${ }^{96}$ Nascimento, Amauri Mascaro. Compêndio de Direito Sindical... Op. cit., p. 192.
} 
movimentos anti-institucionais e anti-autoritários". ${ }^{97}$ Por seu turno, Walküre Lopes Ribeiro da Silva leciona que as terríveis condições de trabalho determinadas pela indústria levaram os trabalhadores à organização coletiva, com a finalidade de apresentar reivindicações aos empregadores, "de início afrontando a lei e depois, com a ascensão do Estado intervencionalista, sob a proteção da lei". ${ }^{98}$

Assim, diante da falência do modelo estatal consolidado, difunde-se o entendimento de que não apenas o Estado, mas outros corpos sociais também se mostram plenamente aptos a regulamentar as condições de trabalho - aliás, provavelmente de forma até mais legítima, vez que melhores conhecedores dos interesses em jogo.

Nesse contexto, ganha relevo a teoria do direito social. Inicialmente desenvolvida por Georges Gurvitch, aludida teoria é apontada por Amauri Mascaro Nascimento como responsável pela expansão do pluralismo jurídico em matéria de direitos sociais, já que reconhece a necessidade de revisão das fontes do direito positivo, com o intuito de obter solução satisfatória para os problemas do Direito do Trabalho. ${ }^{99}$

Com efeito, Georges Gurvitch ${ }^{100}$ foi pioneiro ao consagrar - e definir - a expressão "Direito Social”, até hoje utilizada para aferir-se a natureza jurídica dos direitos trabalhistas. Embora o autor reconheça que, como regra, todo direito pode ser considerado social (na medida em que regulamenta a vida da sociedade), entende que "Direito Social" designa um particular e importante ramo específico do Direito: aquele pautado na justiça distributiva, no qual os valores do todo prevalecem sobre os valores individuais.

Segundo Gurvitch, por isso, apenas é possível reconhecer a existência de um Direito Social se se admitir que há diversos grupos na sociedade (como sindicatos, igrejas, associações, entidades filantrópicas, etc.) e que tais grupos também são aptos a criar leis sociais, plenamente exigíveis, embora, por vezes, não sujeitas à coerção judicial.

De acordo com Cesarino Junior, todo direito é naturalmente social, por isso não pode haver direito senão em sociedade. Porém, no Direito do Trabalho, a expressão "Direito Social" pode ser utilizada em contraposição ao direito individualista,

\footnotetext{
${ }^{97}$ MANnRICH, Nelson. Pluralismo jurídico... Op. Cit., p. 15.

98 Silva, Walküre Lopes Ribeiro da. Autonomia Privada Coletiva. In Revista da Faculdade de Direito da Universidade de São Paulo, v. 102, 2007, p. 135.

${ }^{99}$ NASCIMENTO, Amauri Mascaro. Compêndio de Direito Sindical... Op. cit., pp. 190-191.

${ }^{100}$ Cf. Gurvicth, Georges. The Problem of Social Law. In Ethics, vol. 52, no 1, outubro de 1941, pp. 17-40.
} 
oriundo da Revolução Francesa, significando a prevalência do interesse coletivo sobre o individual. $^{101}$

Em complemento à teoria do direito social, ganha relevo, na Itália, a teoria da autonomia coletiva entre particulares para justificar a atuação dos sindicatos nas relações trabalhistas. Reconhece-se aos grupos sociais a capacidade de regulamentar seus próprios interesses - tal como ocorria com a autonomia privada individual no período liberalista, mas agora pautada na atuação coletiva das organizações.

Consoante Giuseppe Santoro-Passarelli, a autonomia coletiva é uma espécie do gênero "autonomia privada", uma vez que permite "regolamentare non già interessi individuali degli appartenenti all'organizzazione sindacale, ma l'interesse colletivo degli stessi" ${ }^{102}$ No mesmo sentido, o entendimento de Mattia Persiani, para quem a autonomia coletiva difere da individual em virtude dos efeitos do contrato coletivo, que conduzem a uma eficácia do tipo normativo, e não puramente inter partes. ${ }^{103}$

Conforme a seguir abordado ${ }^{104}$, a doutrina italiana defende a natureza de poder originário da autonomia privada coletiva, e não de simples delegação de capacidade normativa às classes sociais. ${ }^{105}$ Nesse sentido, as fontes decorrentes da autonomia privada coletiva e as estatais ocupam o mesmo patamar, determinando a superação do princípio da norma mais favorável para admitir-se a derrogação in peius de normas estatais pela negociação coletiva. ${ }^{106}$

A correlação entre autonomia privada coletiva e pluralismo jurídico vem expressa nas lições de Gino Giugni. Retomando a teoria institucionalista de Santi Romano, Giugni reconhece o caráter de instituição das relações industriais - as quais são, consequentemente, regidas por um ordenamento jurídico próprio, denominado pelo autor de "ordenamento intersindical". Em referido ordenamento, vigem normas próprias,

\footnotetext{
${ }^{101}$ CeSARINO JÚNIOR, A. F.. Direito social: denominação, conceito e conteúdo. In Revista da Faculdade de Direito da Universidade de São Paulo, v. 35, n. 1 (1939), p. 218. É importante ressaltar, porém, que não constitui objeto do presente estudo a análise da natureza jurídica do Direito do Trabalho.

${ }^{102}$ SAntoro-Passarelli, Giuseppe. Diritto Sindacale... Op. Cit., p. 18.

${ }^{103}$ Persiani, Mattia. Dirittto Sindacale. 14 ${ }^{\mathrm{a}}$ Ed.. Padova: CEDAM, 2012, p. 146.

${ }^{104}$ Cf. infra, cap. 2, item 2.2

${ }^{105}$ A respeito, cf. ICHINO, Pietro. Autonomia colletiva e principio di libertà della concorrenza. In Lezioni di diritto del lavoro - Un approccio di labour law and economics. Milano, Giuffrè Editore, 2004, p. 13; PERSIANI, Mattia. Dirittto Sindacale... Op. Cit., p. 146.

${ }^{106}$ A respeito, cf. SILVA, Walküre Lopes Ribeiro da. Autonomia Privada Coletiva... Op. Cit., p. 140.
} 
produzidas pelos interessados, à margem das normas estatais - ainda que estas apresentem o mesmo objeto daquelas. ${ }^{107}$

Ambas as teorias - do direito social e da autonomia privada coletiva foram determinantes para o desenvolvimento da concepção da pluralidade de fontes trabalhistas, e, especialmente, para a justificação do contrato coletivo (expressão utilizada em seu sentido lato, conforme a seguir abordado ${ }^{108}$ ) enquanto criador de condições de trabalho. Entretanto, conforme acima, o tema da pluralidade normativa no Direito do Trabalho merece estudo mais aprofundado, sobretudo na realidade brasileira, diante dos novos posicionamentos doutrinários a respeito do efetivo alcance do pluralismo jurídico especialmente das formas de interação do chamado "direito alternativo" com o direito trabalhista estatal, ou "oficial".

${ }^{107}$ GIUGNI, Gino. Diritto sindacale. Bari: Cacucci Editore, 2012, pp. 18-19. O autor continua sua análise demonstrando que as normas do ordenamento intersindical podem regulamentar a mesma matéria das normas estatais - e, nesse caso, podem surgir conflitos. Este tema, entretanto, será abordado em momento próprio.

${ }^{108}$ Cf. infra, capítulo 2, item 2.4.1 


\subsection{Sistema de fontes trabalhistas e novo pluralismo jurídico}

Por certo, o Direito do Trabalho é marcado por multiplicidade de fontes normativas, as quais englobam desde a lei, até o contrato coletivo ${ }^{109}$, passando pelo costume, regulamentos internos de empresa e pelo próprio contrato individual de trabalho. ${ }^{110}$ Entretanto, a interação das fontes produzidas pelas partes sociais com o direito oficial (ou seja, a lei, em sentido amplo) suscita questionamentos sobre a existência de autêntico pluralismo jurídico no Direito do Trabalho - em especial, no Direito do Trabalho brasileiro. Em outras palavras, questiona-se: qual o efetivo "valor" das normas coletivas perante o direito estatal? Poderia ser o sindicato considerado verdadeira instituição (no sentido propugnado pelas teorias institucionalistas do final do século XIX e início do século XX)? Existe real intuito "emancipatório" nas normas trabalhistas criadas pelas partes sociais (conforme expressão cunhada por Antonio Carlos Wolkmer)?

Tais questionamentos são enfrentados por Nelson Mannrich, para quem não se pode confundir a pluralidade de fontes do Direito do Trabalho com pluralismo jurídico. ${ }^{111}$ Efetivamente, segundo o autor, referido ramo do direito apresenta diversos atores sociais (entre os quais se destacam, além do Estado, a Organização Internacional do Trabalho, os sindicatos, os empregadores, etc.), responsáveis pela criação de diversas fontes normativas (como, e.g., convenções internacionais, acordos e convenções coletivas de trabalho, regulamentos internos de empresa, etc.) - porém, tanto os atores quanto as fontes normativas acima mencionadas inserem-se, integralmente, no direito estatal.

Em outras palavras, no âmbito trabalhista, a ordem estatal mantém-se soberana, na medida em que: a) a vigência de normas internacionais no ordenamento brasileiro depende de ratificação estatal; $b$ ) o regulamento de empresa não pode contrariar a lei; c) a negociação coletiva atua apenas como complemento da lei, podendo, até mesmo, ser anulada judicialmente se contra legem. ${ }^{112} 113$

\footnotetext{
${ }^{109}$ Mais uma vez, expressão utilizada em sentido lato.

${ }^{110} \mathrm{O}$ tema do contrato coletivo enquanto fonte do Direito do Trabalho será abordado a seguir, no capítulo 2.

${ }^{111}$ MANnRICH, Nelson. Pluralismo jurídico... Op. Cit., p. 16.

112 Mannrich, Nelson. Pluralismo jurídico... Op. Cit., p. 16. Assim, para designar tal fenômeno de coexistência de fontes normativas, Mannrich prefere utilizar a expressão "modelos de relações trabalhistas", que podem ser sintetizados em modelo legislado e modelo negociado, "aquele, com predomínio da lei na regulação das relações trabalhistas, com pouco espaço para a autonomia dos grupos; o negociado, com espaço amplo para a negociação coletiva, limitada por intervenções da lei em matérias de interesse público" (Mannrich, Nelson. Pluralismo jurídico... Op. Cit., p. 17). Aprofundando seu posicionamento, o autor afirma que, embora possa haver o predomínio de uma fonte sobre a outra, "nenhum modelo aposta exclusivamente ou na fonte estatal ou na autônoma, havendo a concorrência da lei com a negociação coletiva
} 
Assiste razão ao autor. Excetuadas raras experiências internacionais (especialmente europeias - as quais serão abordadas no momento adequado), a relação entre fontes alternativas e oficiais tende a ser de mera complementariedade: apenas se admite a atuação daquelas quando expressamente permitido por estas e, ainda assim, desde que não as contrariem. Além disso, adentrando-se o campo do direito sindical, em países onde ainda prevalece a unicidade (como o Brasil), até mesmo a afirmação de determinado grupo social enquanto instituição apta a regular seus próprios interesses depende da atuação estatal (exteriorizada, no Brasil, com o registro sindical e com controle efetuado pelo Judiciário e - ainda que indiretamente - pelo Ministério do Trabalho ${ }^{114}$ ). Finalmente, ainda que seja reconhecida legitimidade ao ente sindical, o fruto de suas negociações (i.e., as convenções e os acordos coletivos de trabalho) depende, para sua validade, de registro no Ministério competente.

Por tais razões, entende-se que, no Direito do Trabalho brasileiro, não se pode falar em verdadeiro pluralismo jurídico. Como admitir um "direito alternativo", quando este ainda se encontra quase que totalmente subjugado pelo direito estatal? Como defender o caráter institucional do sindicato se este ainda depende do Estado para nascer e sobreviver?

Não se justifica, nesse sentido, em ambiente de efetivo pluralismo jurídico, a prevalência pura e simples da lei, com espaço extremamente reduzido para a negociação coletiva. ${ }^{115}$ Ao contrário, para consolidação do pluralismo, é mister atribuir maior autonomia às partes sociais, evitando a proliferação de leis, “instáveis, alteradas

para regular as relações de trabalho". Desse equilíbrio, continua, é possível resultarem maiores probabilidades de eficácia do Direito do Trabalho, desde que as regras acerca da interação das fontes sejam claras e, na medida do possível, simples" (MANNRICH, Nelson. Relações entre legislado e negociado: vale a pena retomar esse debate? In Revista Brasileira de Filosofia, v. 237, 2011, pp. 153-170).

${ }_{113}$ Pensamento similar é esposado por Octávio Bueno Magano, quando afirma que, à luz do pluralismo, a sociedade civil concebe-se como conjunto de entes individuais e coletivos em atividade incessante na busca de seus interesses, e o Estado "como o ente ao qual incumbe harmonizar os conflitos surgidos da mesma atividade”. (MAGANO, Octávio Bueno. Liberalismo, corporativismo, pluralismo e neo-corporativismo... Op. cit., p. 57). Ainda, destaca-se, a esse respeito, a lição de Miguel Reale: "Lembrem-se que já nos pronunciamos favoravelmente à teoria da pluralidade dos ordenamentos jurídicos, mas reconhecendo uma gradação de positividade, cujo ápice é representado pelo ordenamento jurídico do Estado" (REALE, Miguel. Lições Preliminares de Direito... Op. cit., p. 189).

${ }^{114}$ Nem se argumente, a esse respeito, que o registro sindical tem mera finalidade de publicizar a criação de sindicatos, na medida em que ainda existe efetivo controle por parte do Ministério do Trabalho em relação à unicidade, sendo-lhe permitido, inclusive, negar o registro no caso de concordância de base territorial e categoria representada. Veja-se, nesse sentido, que a Portaria MTE $\mathrm{n}^{\mathrm{o}} 186$, de 10 de abril de 2008, expressamente prevê hipóteses de indeferimento do pedido de registro sindical pelo Secretário de Relações do Trabalho nos casos de não caracterização da categoria pleiteada; coincidência total de categoria e base territorial do sindicato postulante com sindicato registrado no CNES - Cadastro Nacional de Entidades Sindicais; quando a base territorial requerida englobar o local da sede de sindicato registrado no CNES, representante de idêntica categoria; entre outros.

${ }^{115}$ MANNRICH, Nelson. Relações entre legislado e negociado... Op. Cit. 
antes mesmo de assentadas (...)" ou mesmo muito genéricas, que "apenas contribuem para a insegurança jurídica, quando seduzidas pela ambiguidade". ${ }^{116}$ Nesse sentido, à negociação coletiva não pode ser reservado caráter meramente complementar, acessório à regulamentação efetuada pelo direito oficial.

Retoma-se, neste ponto, a teoria de Antonio Carlos Wolkmer acerca do moderno pluralismo jurídico emancipatório-participativo: se não há interesse em promover modificação social, se as novas fontes normativas têm caráter apenas reacionário e conservador, não há que se falar em verdadeiro pluralismo. ${ }^{117} \mathrm{O}$ autêntico pluralismo jurídico não precisa ser reconhecido pelo Estado para existir - ao contrário, desenvolve-se de forma independente, autônoma, muitas vezes totalmente à margem do direito oficial. ${ }^{118}$ Por óbvio, o pluralismo não prescinde da atuação estatal para seu desenvolvimento e consolidação; porém, deve atuar em conjunto com o Estado, como seu verdadeiro colaborador, e não enquanto simples derivação dele.

Parte-se da teoria proposta por Wolkmer, assim, para sustentar a revisitação dos critérios de interação entre os modelos negociado e legislado no Brasil, garantindo-se o surgimento de verdadeiro pluralismo jurídico, no Direito do Trabalho pátrio, a partir dos fundamentos de efetividade material e formal apontados pelo autor.

Em primeiro lugar, com relação aos novos sujeitos coletivos, sabe-se que, tradicionalmente, os sujeitos coletivos trabalhistas foram identificados, na década de 1970, com os movimentos sindicais da Grande São Paulo ${ }^{119}$, compostos por operários mal remunerados e explorados. Hoje, deve-se reconhecer a ampliação de tais grupos, neles inserindo-se trabalhadores eventuais e autônomos (que buscam a regulamentação de seus direitos); subempregados e desempregados (que buscam a modernização da legislação trabalhista para geração de empregos); trabalhadores admitidos mediante formas contratuais atípicas, como teletrabalho, pejotização, parassubordinação (que buscam a adequação da lei a seus interesses); ocupantes de altos cargos (que buscam a modificação de direitos trabalhistas diante de vantagens tributárias, por exemplo); entre outros. Em suma, trata-se de sujeitos que, em conjunto, sentem-se lesados pela ordem pré-estabelecida e pretendem contra ela insurgir-se, mediante ação coletiva.

\footnotetext{
${ }^{116}$ MANNRICH, Nelson. Relações entre legislado e negociado... Op. Cit.

${ }^{117}$ Cf. supra, item 1.2.

118 Veja-se, por exemplo, o "direito de Pasárgada", que se manifesta, muitas vezes, de forma totalmente contrária ao direito estatal. No mesmo sentido, recorde-se a concepção italiana da autonomia privada coletiva enquanto poder originário, totalmente desvinculado do Estado, com capacidade, até mesmo, de contrariá-lo.

${ }^{119}$ Wolkmer, Antonio Carlos. Pluralismo Jurídico... Op. Cit., p. 238.
} 
Ademais, tradicionalmente, as necessidades humanas relacionadas ao trabalho envolvem salário justo, direito ao descanso, direito ao ambiente de trabalho salubre, etc. Porém, hoje, as necessidades humanas fundamentais podem também estar relacionadas com aspirações econômicas do trabalhador e da empresa: interesse no desenvolvimento do empregador, na maior lucratividade (com repasse de benefícios aos empregados), na redução de encargos tributários, etc.

Por meio da reordenação do espaço político, espera-se maior participação dos atores sociais na feitura das leis e nos fóruns de debates sociais. Tal espaço já foi angariado pelas centrais sindicais, a partir de seu reconhecimento expresso na Lei $\mathrm{n}^{\mathrm{o}}$ 11.648/08 (embora estas ainda se encontrem à margem do sistema sindical brasileiro, dotadas de natureza jurídica de meras associações civis). Destaca-se também a competência dos sindicatos para propositura de ações coletivas e participação na política brasileira (a despeito de ainda lhes ser vedada a atividade político-partidária). ${ }^{120}$

Com relação a tal fundamento, entretanto, deve-se ter cuidado para que o sindicato não volte a representar mero "braço" do Estado, mas seja dotado de efetiva natureza institucional - o que, como se sabe, somente poderá ser obtido mediante a superação da unicidade sindical.

Por força da ética concreta da alteridade, valores universais do trabalho (salário justo, salubridade das condições laborais, limitação da jornada) passam a ser combinados com necessidades específicas de grupos normalmente alijados da legislação protetiva laboral, tanto empregados, quanto empregadores. Ganha relevo a necessidade de combater a "crise" do Direito do Trabalho, tanto do ponto de vista do empregador (diante da necessidade de redução dos custos trabalhistas) quanto do empregado (mediante regulamentação de novas formas de trabalho, fomento do emprego formal, redução das formas de subemprego, etc.). Para a operacionalização dessa nova ética, é necessário haver verdadeira interação entre as classes, que atuam como parceiras na consecução de um objetivo comum. Aqui, assiste razão a Karl-Otto Apel, também integrante da escola de Frankfurt (assim como Habermas), para quem é necessário fortalecer a denominada "ética

\footnotetext{
${ }^{120}$ A respeito do tema, Mauricio Godinho Delgado questiona a recepção, pela Constituição da República de 1988, dos artigos 511 e 521, $d$, da CLT - os quais vedam o exercício de atividades políticas pelos sindicatos brasileiros. Com efeito, segundo o autor, embora não seja recomendável a vinculação de sindicatos a partidos políticos, bem como sua subordinação a linhas político-partidárias, tal proibição não deve ser confundida com a ideia de "proibição normativa de exercício eventual de ações políticas". Assiste-lhe razão, nesse sentido, ao afirmar que "inúmeras questões aparentemente de cunho apenas político podem, sem dúvida, influenciar, de modo relevante, a vida dos trabalhadores e de seus sindicatos" - como, por exemplo, a política econômica oficial de determinado Estado. (Delgado, Mauricio Godinho. Curso de Direito do Trabalho.. $11^{\mathrm{a}}$ Ed.. São Paulo: LTr, 2012, pp. 1361-1362).
} 
da responsabilidade", que se articula por meio da interação social e possibilita as condições de existência da Comunidade ideal com a Comunidade real. ${ }^{121}$

Finalmente, segundo a crítica marxista, a racionalidade clássica, imposta pelo modelo liberal-burguês, induz sobre a sociedade uma estrutura de forças produtivas mercantilizadas e relações sociais coisificadas. ${ }^{122}$ Assim, pela racionalidade emancipatória, deve-se buscar uma consciência de classe verdadeira, com plena convicção de que a finalidade do Direito do Trabalho desloca-se da pura e simples proteção do trabalhador para a defesa do pleno emprego, especialmente de forma a permitir que "os interlocutores sociais possam, em cada situação concreta, compor os seus interesses diretamente, sem a interferência do Estado e pela forma que julgarem mais adequada ao respectivo momento (...)". ${ }^{123}$

Não por outra razão, Amauri Mascaro Nascimento afirma que o Direito do Trabalho passou por fases diferentes: a da conquista e a promocional. Atualmente, encontra-se no início de fase de adaptação à nova realidade, em um processo dialético de transformações em que se insere "e do qual deve resultar um novo modelo que o represente, no qual a sociedade enfrenta uma série de dificuldades que atingem, mais intensamente, exatamente aqueles que não têm um emprego formal garantido". ${ }^{24}$

Veja-se, assim, que o pluralismo jurídico no Direito do Trabalho só pode ser alcançado diante do preenchimento de todos os fundamentos acima - os quais passam, necessariamente, pelo maior poder atribuído aos sindicatos.

No Brasil, em virtude dos resquícios corporativistas contidos na legislação e na própria ideologia que norteia o Direito do Trabalho, torna-se ainda mais difícil reconhecer a existência de efetivo pluralismo. Como visto, o sindicato sofre crise de representatividade oriunda de sua própria estrutura normativa, marcada por características opostas à liberdade, como contribuição compulsória, unicidade e vinculação ao conceito de categoria. A atuação da Justiça do Trabalho enfraquece os atores sociais, na medida em que prioriza métodos de heterocomposição em detrimento da autocomposição. As próprias convenções coletivas de trabalho - teoricamente, principal instrumento normativo do pluralismo - encontram-se tolhidas por formalidades muitas vezes injustificáveis (registro

121 A respeito, cf. APEL, Karl-Otto. How to ground a universalistic ethics of co-responsibility for the effects of collective actions and activities? In Philosofica, $\mathrm{n}^{\circ} 52$ (1993, 2), pp. 9-29.

${ }_{122}$ Cf. LUKÁCS, Georg. História e consciência de classe. São Paulo: Martins Fontes, 2003, pp. 133-148

${ }^{123}$ Nascimento, Amauri Mascaro. Curso de Direito do Trabalho. 25 a edição. São Paulo: Saraiva, 2010, p. 70.

124 NASCIMENTO, Amauri Mascaro. Limites da negociação coletiva na perspectiva de projeto de flexibilização da CLT. In Revista LTr, vol. 65, nº 12, dezembro de 2011, p. 1419. 
no Ministério do Trabalho, aprovação em assembleia por quórum previsto na CLT, etc.) e enfraquecidas diante de conflitos com a legislação tuitiva, nos quais esta sempre prevalece em prejuízo dos interesses específicos das partes.

De fato, conforme ressalta Nelson Mannrich, a reforma do Direito do Trabalho e a flexibilização não podem ser impostas de forma unilateral, devendo contar, sempre, com a participação dos atores sociais. Nesse sentido, não pode a empresa flexibilizar unilateralmente (sob o argumento de redução de custos e sobrevivência), mediante, e.g., formas abusivas de contratação, e o Estado não pode reformar sem antes ouvir as classes profissionais e patronais interessadas na mudança. O consenso é primordial para a reforma. ${ }^{125}$

Amauri Mascaro Nascimento pugna pelo desenvolvimento de "sistemas neoliberais de relações trabalhistas", um sistema desregulamentado que passa a ser basicamente negociado. ${ }^{126}$

Nas palavras de Mannrich, deve-se devolver aos atores sociais o espaço indevidamente invadido pelo Estado, para que ambos, em conjunto, possam fazer as alterações necessárias na legislação trabalhista em vigor.

Contudo, entende-se que, para que ocorra essa efetiva "devolução" de legitimidade aos atores sociais, é necessário repensar dogmas arraigados do Direito do Trabalho, a começar, pelo sistema de fontes trabalhistas e sua interação diante do princípio da proteção - matérias de que cuidarão os próximos capítulos do presente trabalho.

\footnotetext{
${ }^{125}$ MANNRICH, Nelson. Pluralismo jurídico... Op. Cit., p. 16.

${ }^{126}$ NASCIMENTO, Amauri Mascaro. Iniciação ao Direito do Trabalho... Op. Cit., p. 267.
} 


\section{Acordos e convenções coletivas enquanto fonte do Direito do Trabalho}

\subsection{Fontes do Direito sob o viés trabalhista ${ }^{127}$}

Para identificar a fonte de um rio, é preciso encontrar o local onde suas águas aforam à terra. Para identificar as fontes do Direito, deve-se perquirir o ponto em que estas emergem das profundezas da vida social para aparecerem à superfície do Direito. É o que afirma Claude du Pasquier, a respeito do tema ora estudado. ${ }^{128}$

No entender de António Monteiro Fernandes, fontes do Direito são modos de produção e revelação das normas jurídicas, ou seja, instrumentos mediante os quais tais normas são estabelecidas e expostas ao conhecimento público. ${ }^{129}$ O jurista francês François Geny foi responsável pela categorização das fontes do Direito em substanciais (ou materiais), i.e., elementos históricos, racionais e ideais que, embora não sejam verdadeiras prescrições, contribuem para a formação do Direito, e formais, i.e., formas solenes de exteriorização dos aspectos materiais que ensejam o surgimento das normas jurídicas. ${ }^{130}$

Por seu turno, Tercio Sampaio Ferraz Junior associa o conceito de fontes do Direito à questão das antinomias e lacunas do ordenamento visto como sistema. Em suas palavras, "se, num sistema, podem surgir conflitos normativos, temos que admitir que as normas entram no sistema a partir de diferentes canais, que, com relativa independência, estabelecem suas prescrições". Ademais, se ocorrem lacunas no ordenamento, "é porque se aceita que o sistema, a partir de um centro produtor unificado, não cobre o universo dos comportamentos, exigindo-se outros centros produtores". ${ }^{131}$

\footnotetext{
${ }^{127}$ Por questões metodológicas e de delimitação do tema, optou-se, no presente trabalho, pela análise das fontes jurídicas única e exclusivamente sob o viés trabalhista - já que o estudo genérico das fontes do Direito é matéria que releva à Teoria Geral do Direito, não constituindo objeto da presente pesquisa.

${ }^{128}$ PASQUIER, Claude du. Introduction à la théorie générale et à la philosophie du Droit. Paris: Delachaux \& Niestlé, 1979, p. 47.

${ }^{129}$ FERnANDES, António Monteiro. Direito do trabalho. 15a edição. Coimbra: Almedina, 2010, p. 63.

${ }^{130}$ Para mais informações sobre o tema, cf. GENY, François. Methode d'interprétation et sources en droit prive positif: essai critique. $2^{\text {a }}$ Ed.. Vol. 1. Paris: Librairie générale de droit \& de jurisprudence, 1954.

${ }^{131}$ FerRAZ Junior, Tercio Sampaio. Introdução ao Estudo do Direito - técnica, decisão, dominação. $4^{\mathrm{a}}$ Ed. São Paulo: Atlas, 2003.
} 
As fontes pressupõem, necessariamente, uma estrutura de poder, "desde o poder capaz de assegurar por si o adimplemento das normas por ele emanadas (...) até outras formas subordinadas de poder que estabelecem (...) relações que permitem seja pretendida a garantia da execução outorgada pelo Estado". ${ }^{132}$

Nesse contexto, as estruturas de poder existentes na sociedade hodierna levam Miguel Reale a apontar quatro modalidades de fontes jurídicas: a legal, resultante do poder estatal; a consuetudinária, decorrente dos costumes do grupo social; a jurisdicional, oriunda do Poder Judiciário; e a negocial, decorrente da autonomia da vontade. $^{133}$

O Direito do Trabalho também obedece a tal estrutura. Com efeito, ao lado da legislação estatal - a qual, como se viu ${ }^{134}$, foi pioneira na regulamentação das relações trabalhistas -, coexistem normas emanadas do costume, da jurisprudência, da Organização Internacional do Trabalho (OIT), do Poder Executivo e, sobretudo, das próprias partes sociais. Assim, o ordenamento jurídico laboral estrutura-se de forma complexa $^{135}$, na medida em que suas regras decorrem não de uma única fonte notmativa, mas de um emaranhado delas.

Embora, em rigor, todos os ordenamentos jurídicos atuais possam ser classificados como complexos ${ }^{136}$, já que muito dificilmente serão compostos por uma única fonte normativa ${ }^{137}$, é certo que o ordenamento laboral apresenta maior complexidade, quer pelos sujeitos envolvidos na elaboração de normas jurídicas, quer pela natureza e interação de referidas normas.

\footnotetext{
${ }^{132}$ REALE, Miguel. Lições preliminares de Direito..., Op. Cit., p. 139.

${ }^{133}$ REALE, Miguel. Lições preliminares de Direito..., Op. Cit., p. 139.

${ }_{134} \mathrm{Cf}$. infra, cap. 1, item 1.2.

$135 \mathrm{Na}$ classificação proposta por Norberto Bobbio, para quem os ordenamentos jurídicos podem ser diferenciados em simples ou complexos, a depender da quantidade de fontes normativas existentes (BOBBIO, Norberto. Teoria do Ordenamento Jurídico..., Op. Cit., p. 37).

${ }^{136}$ Segundo Nelson Mannrich, entende-se por complexidade, "mais que a simples pluralidade de elementos, aquilo que está sendo tecido junto. É a união da ordem e da desordem, na tentativa de integrar as liberdades e desordens que podem suscitar a adaptabilidade e a criatividade, pois o aumento da complexidade resulta da circunstância da solidariedade vivida (...). Na verdade, o pensamento complexo surge para questionar o pensamento cartesiano; sai-se da linearidade para entrar na circularidade: eu afeto e sou afetado; sociedade e indivíduo são produto e produtores". Ademais, o autor afirma que complexidade e complicação são duas coisas muito diferentes, na medida em que "complicação" é a falta de ordem, a desorganização, enquanto "complexidade" é uma estratégia de gerenciamento de relações e situações. Assim, "na complexidade não se fala de uma coisa OU outra, mas sim de uma coisa E outra". Com a complexidade, assim, o homem ganha a liberdade (MANNRICH, Nelson. Relações entre legislado e negociado... Op. Cit.).

137 Conforme, aliás, reconhecido pelo próprio Norberto Bobbio, ao afirmar que "a imagem de um ordenamento, composto somente por dois personagens, o legislador que coloca as normas e os súditos que as recebem, é puramente escolástica” (BOBBIO, Norberto. Teoria do Ordenamento Jurídico..., Op. Cit., p. 37).
} 
Maria do Rosário Palma Ramalho atribui referida complexidade a diversos fatores, a saber: a) a coexistência, a par das fontes comuns, de modos de produção de normas de natureza específica; b) a natureza peculiar de algumas fontes laborais, como a convenção coletiva e, em Portugal, a portaria de extensão; c) a possibilidade de participação direta dos parceiros laborais na elaboração das normas, com amplo poder de autorregulação; d) a peculiaridade da relação entre as fontes, especialmente no que tange à solução dos conflitos surgidos entre elas. ${ }^{138}$

Percebe-se que todos os fatores apontados pela autora convergem, em certa medida, para aspecto comum: a circunstância de que, no Direito do Trabalho, não apenas o legislador possui capacidade normativa, mas também o Poder Executivo, a jurisprudência e as próprias partes sociais. A complexidade reside, assim, em compatibilizar as normas produzidas por todos esses sujeitos sem comprometer o intuito de proteção que sempre norteou esse peculiar ramo da ciência jurídica.

A premissa básica de que se deve partir para análise da estrutura das fontes laborais é o entendimento de que a lei stricto sensu, historicamente, tem primazia sobre as demais fontes. Tal primazia justifica-se, inicialmente, em virtude da própria ordem de surgimento das fontes laborais: antes mesmo da negociação coletiva, adveio a lei como instrumento de regulamentação da "questão social""139 (embora já presentes manifestações sociais coletivas, sem, entretanto, poder normativo); somente após a consolidação do sistema positivo é que surgiriam outros métodos de adaptação da lei ao caso concreto, como a jurisprudência e os contratos coletivos.

Em segundo lugar, referida primazia manifesta-se no esquema de interação tradicionalmente adotado pelos ordenamentos laborais: o conflito entre lei e outras fontes é orientado pelo denominado "princípio da norma mínima”, segundo o qual o legislador, ao intervir nas relações laborais, não o faz eliminando por completo a autonomia da vontade ou outras fontes normativas, mas estabelecendo alguns limites para sua atuação. ${ }^{140}$

\footnotetext{
${ }^{138}$ Ramalho, Maria do Rosário Palma. Direito do Trabalho. Parte I - Dogmática Geral. $2^{\mathrm{a}}$ edição. Coimbra: Almedina, 2009, p. 155.

${ }_{139}$ Para mais informações sobre a questão social, cf., por todos, CeSARINO JUNIOR, A.F.. Direito Social Brasileiro. 6 6 Ed.. São Paulo: Saraiva, 1970.

${ }^{140}$ A respeito, cf. UguinA, Jesús R. Mercader. La silenciosa decadencia del principio de norma más favorable. In CIVITAS - Revista Española de Derecho del Trabajo, nº 109, Enero-Febrero 2002, Madri, pp. 25-26.
} 
Assim, tomando-se a lei como norte da tutela das relações laborais, é que se mostra possível a análise das demais fontes trabalhistas.

Neste ponto, é certo que a maior ou menor importância atribuída a cada uma das fontes acima mencionadas (negocial, legal, consuetudinária e jurisprudencial) dependerá da estrutura de cada ordenamento jurídico. Por exemplo, em países onde predomina a common law, atribuir-se-á maior relevo às fontes jurisprudenciais, enquanto, em Estados de índole autoritária, o Poder Executivo terá grande destaque na regulamentação das relações trabalhistas. Entretanto, por certo, uma das fontes acima mencionadas apresenta importância equânime nos diversos ordenamentos ao redor do mundo, quer em virtude de sua relevância histórica, quer por força de sua grande capacidade de adaptação das leis à realidade social: a fonte negocial.

Com efeito, a negociação direta entre os atores sociais - especialmente coletiva - é um dos pilares do Direito do Trabalho. ${ }^{141}$ Não por outra razão, aliás, já se afirmou que sua existência é o que justifica a própria autonomia científica do ordenamento juslaboral. ${ }^{142}$ De fato, embora o Direito do Trabalho tenha assentado suas bases em institutos de tutela estatal, foi complementado por um direito das relações coletivas, mediante a criação de sindicatos, contratos coletivos e instrumentos de autotutela para solução de conflitos. ${ }^{143}$

A fonte negocial, no entender de Miguel Reale, é caracterizada por quatro elementos: a) manifestação de vontade de pessoas legitimadas a fazê-lo; b) forma que não contrarie a exigida em lei; c) objeto lícito e d) quando não paridade, pelo menos uma relativa proporção entre os partícipes da relação jurídica. ${ }^{144}$ É por força do quarto requisito que, no Direito do Trabalho - embora também seja, por vezes, admitida a negociação direta entre empregado e empregador (por exemplo, no que tange a condições do contrato de trabalho) -, prevalece a negociação efetuada entre entes coletivos, na

\footnotetext{
${ }^{141}$ Contudo, a despeito de primordial ao Direito do Trabalho, a fonte negocial não costuma receber o devido interesse por parte da doutrina. Segundo leciona Miguel Reale, tal descaso mostra-se totalmente inadequado, já que o homem, enquanto ser capaz de direitos e obrigações, detém o "poder de estipular negócios para a realização de fins lícitos, graças a acordo de vontades" (REALE, Miguel. Lições preliminares de Direito..., Op. Cit., p. 179).

${ }^{142}$ VICENTE PALACIO, Arantzazu. La negociación colectiva... Op. Cit., p. 259.

${ }^{143}$ Cf. DuRAnd, Paul. Le fonti del diritto del lavoro in Francia... Op. Cit., p. 105.

${ }^{144}$ REALE, Miguel. Lições preliminares de Direito..., Op. Cit., p. 180.
} 
medida em que o sindicato, enquanto defensor do interesse coletivo ${ }^{145}$, estaria apto a "assegurar a existência de efetiva equivalência entre os sujeitos contrapostos". 146

Especificamente no âmbito coletivo, a fonte negocial é respaldada no plano constitucional por diversos países (em Constituições denominadas por Amauri Mascaro Nascimento de "prescritivas" ${ }^{147}$ ), como Espanha (art. 37.1: “La ley garantizará el derecho a la negociación colectiva laboral entre los representantes de los trabajadores y empresarios, así como la fuerza vinculante de los convenios" ${ }^{148}$ ), Portugal (art. 56.3: “Compete às associações sindicais exercer o direito de contratação colectiva, o qual é garantido nos termos da lei") e Brasil (art. $7^{\circ}$, XXVI).

A importância da fonte negocial, ademais, sobressai quando se reconhece que o espaço a ela assegurado por determinado ordenamento jurídico permite classificar o modelo de relações de trabalho no país. No entender de Amauri Mascaro Nascimento, quanto à interação das fontes, os sistemas trabalhistas podem ser classificados em negociados, legislados e comunitários. ${ }^{149}$ Por seu turno, Nelson Mannrich aponta a existência de apenas dois modelos, o negociado e o legislado. ${ }^{150}$

Conforme já salientado, é natural que, em determinado ordenamento, uma fonte tenha maior relevância do que outra - a depender do momento histórico, social, econômico e político em que o sistema se encontre. Duas ponderações, todavia, fazem-se necessárias para adequada compreensão dos modelos acima descritos: a) afirmar que certo ordenamento segue um ou outro modelo não significa dizer que admite apenas uma fonte normativa: ao contrário, em todos os modelos, tanto a fonte legal quando a negocial coexistem, apenas variando o grau de atuação delas; e b) a prevalência de um modelo sobre outro reflete as aspirações sociais de determinado momento, sendo perfeitamente possível que um Estado com modelo legislado passe a dar prevalência ao negociado em outras circunstancias históricas, e vice-versa.

É, com efeito, o que leciona Nelson Mannrich, ao afirmar que, embora possa haver o predomínio de uma fonte sobre a outra, nenhum modelo aposta

\footnotetext{
${ }^{145} \mathrm{O}$ qual será a seguir estudado com mais vagar.

${ }^{146}$ Delgado, Mauricio Godinho. Curso de Direito do Trabalho... Op. Cit., p. 1335.

${ }^{147}$ Nascimento, Amauri Mascaro. Compêndio de Direito Sindical... Op. Cit., p. 447.

148 “A lei garantirá o direito à negociação coletiva laboral entre os representantes dos trabalhadores e empresários, assim como a força vinculante dos convênios" - tradução livre.

149 Nascimento, Amauri Mascaro. Compêndio de Direito Sindical...Op. Cit., p. 423.

${ }^{150}$ MANnRICH, Nelson. Relações entre legislado e negociado... Op. Cit.. Ainda, com base na classificação das fontes acima apresentada, Miguel Reale categoriza os modelos em negociais, legais, consuetudinários e jurisdicionais (REALE, Miguel. Filosofia do Direito. Op. Cit., p. 554).
} 
exclusivamente na fonte estatal ou na autônoma, sempre havendo a concorrência de ambas na regulamentação das relações trabalhistas (a despeito de uma se mostrar mais atuante do que a outra). Além disso, a opção por um modelo ou outro, continua o autor, vincula-se a duas questões centrais, que podem variar conforme a situação histórica enfrentada: eficácia econômica do Direito do Trabalho, mediante a qual se deve conferir ao empregador certos mecanismos, como poder de direção, e eficácia social no âmbito dos direitos assegurados ao trabalhador, "seja na condição de ser humano, cuja dignidade deverá ser preservada, seja na condição de cidadão, mesmo quando se encontra no local de trabalho". ${ }^{151}$

O sistema negociado, nesse sentido, confere prevalência à autonomia da vontade, tanto coletiva quanto individual. A regulamentação é feita quase que exclusivamente por contratos coletivos de trabalho, restringindo-se a atuação da lei apenas a matérias consideradas indisponíveis, como saúde e segurança do trabalhador. Amauri Mascaro Nascimento classifica tais sistemas como "desregulamentados", na medida em que suas normas não são impostas pelo Estado, valorizando-se a ideia de "contrato". 152

Naturalmente, em referido sistema, a jurisdição apresenta papel secundário, já que eventuais conflitos tendem a ser resolvidos no seio da própria sociedade. Destaca-se a importância de métodos alternativos de solução de controvérsias, como mediação e arbitragem, bem como a solução de conflitos pelas próprias empresas, internamente, sem recurso ao Poder Judiciário.

Como exemplo de sistema tipicamente negociado, Amauri Mascaro Nascimento aponta o norte-americano, no qual existem poucas leis sobre direitos individuais do trabalhador. A despeito de haver algumas leis regulamentando a negociação coletiva (National Labor Relations Act ou Wagner Act, de 1935, Labor Management Relations Act ou Taft-Hartley Act, de 1947, Railway Labor Act, de 1936 e Labor

\footnotetext{
151 MANnRICH, Nelson. Relações entre legislado e negociado... Op. Cit.. No mesmo sentido, o posicionamento de Tereza Aparecida Asta Gemignani: "nesse contexto, os acalorados debates pautados pela mentalidade de exclusão, no sentido de ter que escolher se deveria prevalecer "o acordado ou o legislado", apontam para um foco equivocado, pois não se trata de optar por um em detrimento de outro, mas de construir um processo de coexistência de ambos para que possa ser implementado o legislado e também o acordado, mediante um permanente diálogo das fontes normativas, que deve ocorrer de forma dinâmica e não estática" (Gemignani, Tereza Aparecida Asta. Direitos coletivos e direitos fundamentais: o diálogo das fontes e a função promocional do direito. In Revista do Tribunal Superior do Trabalho, Brasília, vol. 78, $\mathrm{n}^{\mathrm{o}} 2$, abr/jun de 2012, p. 445).

${ }^{152}$ NASCIMENTO, Amauri Mascaro. Compêndio de Direito Sindical... Op. Cit, p. 423.
} 
Management Reporting and Disclosure Act, de 1959), a organização sindical não é moldada por elas - razão pela qual predomina intenso pluralismo sindical no país. ${ }^{153}$

Por seu turno, o sistema legislado caracteriza-se por supremacia da lei, dirigismo estatal e menor autonomia na regulamentação das relações de trabalho. Nesse sistema, prevalece o conceito de "norma mínima" e os conflitos entre lei e negociação coletiva tendem a ser guiados pelo princípio da norma mais favorável, a seguir analisado.

Ressalte-se, mais uma vez, que o sistema em comento não ignora a importância da negociação coletiva para regulamentação das relações trabalhistas in concreto: ao contrário, mesmo os sistemas extremamente legalistas (como, por exemplo, o brasileiro) tendem a reconhecer referida forma de normatização, inclusive atribuindo natureza de fonte às convenções e acordos coletivos de trabalho dela decorrentes. Frise-se, porém, seu caráter secundário perante a legislação estatal.

Consoante salientado, o sistema brasileiro, atualmente, enquadra-se em referido modelo, bem como os demais sistemas latino-americanos. ${ }^{154}$

Finalmente, os sistemas comunitários caracterizam-se pela elaboração de normas trabalhistas que abrangem diversos Estados soberanos. É, como se sabe, o direito dos Estados pertencentes à União Europeia - os quais se mostram cada vez mais interligados por um direito e uma jurisdição comuns.

Importante ressaltar, todavia, que também no direito comunitário, além das normas aplicáveis a toda a Comunidade, coexistem normas estatais elaboradas por cada país e instrumentos de negociação coletiva - os quais, aliás, começam a também assumir faceta comunitária nos últimos anos. Mais uma vez, portanto, percebe-se a impossibilidade de construir-se sistema absolutamente puro, formado por somente uma fonte normativa. Por sinal, é desse equilíbrio entre diversas fontes que, segundo Nelson Mannrich, resultam "maiores probabilidades de eficácia do Direito do Trabalho, desde que as regras sejam claras e, na medida do possível, simples". ${ }^{155}$

Constatada, assim, a importância da fonte negocial para a construção de um Direito do Trabalho eficaz e condizente com as necessidades específicas dos grupos

\footnotetext{
153 Nascimento, Amauri Mascaro. Compêndio de Direito Sindical... Op. Cit, p. 423. Para mais informações sobre referidas leis, cf. TROTTA, Maurice S. Collective Bargaining - Principles, Practices, Issues. Nova Iorque: Simmons-Boardman Publishing Corporation, 1961, p. 15 e ss.

${ }^{154}$ Nascimento, Amauri Mascaro. Compêndio de Direito Sindical... Op. Cit, p. 424.

${ }^{155}$ MANNRICH, Nelson. Relações entre legislado e negociado... Op. Cit..
} 
sociais, é preciso analisar os fundamentos que orientam sua atuação na sociedade hodierna e permitem perquirir sobre sua natureza de efetiva fonte do Direito do Trabalho: autonomia privada coletiva e interesse coletivo. 


\subsection{Autonomia privada coletiva}

Segundo Miguel Reale, a autonomia da vontade é uma "conquista impostergável da civilização", consubstanciada no "poder que tem cada homem de ser, de agir e de omitir-se nos limites da lei em vigor, tendo por fim alcançar algo de seu interesse e que, situado no âmbito da relação jurídica, se denomina bem jurídico" ${ }^{156}$ Não por outra razão, Immanuel Kant - apontado como o criador da expressão "autonomia da vontade" afirma que autonomia é o fundamento da "dignidade da natureza humana e de toda a natureza racional". ${ }^{157}$

Sabe-se que a autonomia da vontade é princípio basilar do Estado Democrático de Direito. Além de relacionar-se à esfera de liberdade individual do cidadão diante do Estado ${ }^{158}$, também representa a possibilidade de autorregulação de interesses pelo particular, i.e., de criação de relações jurídicas segundo anseios concretos do produtor da norma (obviamente, sempre respeitada a legalidade). ${ }^{159}$

É o que leciona Orlando Gomes, ao afirmar que o princípio da autonomia da vontade, ligado à liberdade de contratar, representa "o poder dos indivíduos de suscitar, mediante declaração de vontade, efeitos reconhecidos e tutelados pela ordem jurídica". ${ }^{160}$ Trata-se, portanto, de verdadeiro poder atribuído aos particulares, e não mera faculdade. ${ }^{161}$

Com efeito, desde suas origens, o Direito reconhece autonomia aos particulares para regulamentar as relações desenvolvidas entre eles - trata-se da denominada "autonomia privada", que pode ser compreendida como decorrência do fenômeno de "descentralização normativa"162, ou seja, da atribuição, a certas entidades, da capacidade de emitirem regras de conduta concorrentes com as normas estatais. Segundo António Monteiro Fernandes, o que confere conteúdo próprio ao conceito de autonomia

\footnotetext{
${ }^{156}$ REALE, Miguel. Lições preliminares de Direito. 27 edição. São Paulo: Saraiva, 2012, p. 179.

157 KANT, Immanuel. Fundamentação da Metafísica dos Costumes. Lisboa: Edições 70, 2007. É importante ressaltar, mais uma vez para fins de delimitação da pesquisa, que sobre o conceito de autonomia da vontade só serão tecidas as breves considerações necessárias ao desenvolvimento da tese.

${ }^{158} \mathrm{Ou}$, nas palavras de Canotilho, "vinculação dos poderes públicos a conteúdos, formas e procedimentos do Estado de direito" (CAnotilho, Joaquim José Gomes. Direito Constitucional. 6 $6^{\text {a }}$ edição. Coimbra: Almedina, 1993, p. 363).

${ }^{159}$ Até mesmo porque, conforme bem leciona Luigi Ferri, desconsiderando-se a importância da legalidade para compreensão da autonomia, chegar-se-ia a perspectiva tão ampla que permitiria abarcar, na autonomia, até mesmo a noção de delito (FERRI, Luigi. L'autonomia privata. Milano: Giuffrè, 1959, p. 345).

${ }^{160}$ GOMES, Orlando. Contratos. Rio de Janeiro. Forense, 2001, p. 37.

${ }^{161}$ Segundo leciona FERRI, Luigi. L'autonomia privata... Op. Cit., p. 345.

${ }^{162} \mathrm{Na}$ expressão de FERnANDES, António Monteiro. Direito do trabalho... Op. Cit., p. 688.
} 
privada é o fato de o fundamento das normas produzidas "se situar na esfera de fins ou interesses da entidade emissora e ter por alvo comportamentos pertencentes à sua própria área de actuação". ${ }^{163}$

Diante do quanto acima exposto, a doutrina tende a classificar a autonomia da vontade em três diferentes espécies.

Inicialmente, destaca-se a autonomia pública, típica do Estado e das pessoas jurídicas de direito público. Consiste na capacidade de os órgãos públicos emitirem regras ou comandos internos, com vistas à autorregulação financeira, administrativa, patrimonial, etc. Por apresentar viés nitidamente publicista, envolve interesse de toda a comunidade ${ }^{164}$, que é indivisível (ao contrário do interesse individual ou do grupo, que tem por característica a divisibilidade).

Segundo ressalta Walküre Lopes Ribeiro da Silva, há duas diferenças fundamentais entre a autonomia pública e a dos particulares: em primeiro lugar, a autonomia privada quase sempre se concretiza em negócios jurídicos bilaterais, enquanto a pública se expressa, na maioria das vezes, por atos unilaterais da Administração (por força da condição de igualdade entre os sujeitos no campo da autonomia privada e da condição de supremacia do Estado); em segundo, com relação aos limites impostos por lei, a liberdade do particular é plena, dentro da legalidade, enquanto o Poder Público "goza daquela particular liberdade que se denomina discricionariedade", já que deve perseguir fins que não são escolhidos livremente por ele, mas impostos pela lei. ${ }^{165}$

Ao lado da autonomia pública, destaca-se a autonomia privada, a qual, por seu turno, pode ser classificada em individual ou coletiva.

A autonomia privada individual corresponde à capacidade de regulamentação dos interesses pelos próprios particulares, a partir de declarações de vontade negocial. Trata-se, como se sabe, da autonomia surgida no período do liberalismo, do qual o contrato ${ }^{166}$ é a manifestação mais evidente. ${ }^{167}$ No campo trabalhista, representa a

\footnotetext{
${ }^{163}$ FERnANDES, António Monteiro. Direito do trabalho... Op. Cit., p. 688.

164 Enquanto a autonomia privada coletiva, como se verá, envolve apenas o interesse de um grupo individualmente considerado (cf. SiLva, Walküre Lopes Ribeiro da. Autonomia Privada Coletiva... Op. Cit., p. 142).

${ }^{165}$ SILVA, Walküre Lopes Ribeiro da. Autonomia Privada Coletiva... Op. Cit., p. 143.

${ }^{166}$ Embora haja discussões sobre a efetiva natureza de fonte do contrato de trabalho: por exemplo, segundo Maurício Godinho Delgado, o contrato de trabalho não pode ser considerado verdadeira fonte de Direito na medida em que "não se qualifica como diploma instituidor de atos-regra, de comandos abstratos, gerais, impessoais", mas se compõe de "cláusulas concretas, específicas e pessoais, envolvendo apenas as partes contratantes" (Delgado, Mauricio Godinho. Curso de Direito do Trabalho... Op. Cit., p. 172).
} 
capacidade de empregado e empregador, sujeitos livres e iguais, determinarem livremente os termos e as condições de troca da força de trabalho por um preço - pensamento típico do Liberalismo Econômico e dos primeiros contratos de prestação de serviços.

Por seu turno, a autonomia privada coletiva (ou autonomia coletiva profissional) refere-se à possibilidade de composição de interesses mediante acordos entre grupos sociais, dos quais advêm normas abstratas que irão reger as relações individuais dos membros do grupo. A principal manifestação da autonomia coletiva, como se sabe, são as convenções e acordos coletivos de trabalho - os quais, quanto a seus efeitos, em muito se assemelham à legislação estatal, dela diferindo no que tange aos sujeitos criadores e ao processo de elaboração. ${ }^{168}$ Segundo Walküre Lopes Ribeiro da Silva, na linha do que defende a doutrina italiana, é a autonomia privada coletiva que justifica não só a negociação coletiva, mas também a própria liberdade sindical e a greve. ${ }^{169}$

Conforme explicitado ${ }^{170}$, a importância da autonomia privada coletiva para o âmbito trabalhista é reconhecida, inicialmente, na Itália, com o objetivo de justificar a atuação dos sindicatos na criação de condições de trabalho. ${ }^{171}$

Entretanto, as discussões a respeito da negociação coletiva enquanto manifestação da autonomia privada apenas ganham corpo após a queda do regime corporativista italiano. Até então, grande parte da doutrina entendia que a autonomia coletiva enquadrava-se no conceito de autonomia pública, em vista da estreita relação entre sindicatos e Estado. ${ }^{172}$ Com a devida vênia, porém, tal entendimento não merece prosperar. Como bem ressalta António Monteiro Fernandes, a autonomia coletiva sempre se situa no campo das relações privadas, mas poderá assumir feição publicista, a depender da intensidade da aproximação entre grupos sociais e Estado em determinado modelo jurídico - como ocorre nos sistemas corporativistas, em que a plena vinculação entre Estado e grupos sociais transforma o sindicato em interlocutor direto da política estatal. ${ }^{173}$

De qualquer maneira, após a queda do corporativismo, o art. 1322 do Código Civil italiano expressamente retoma a discussão da autonomia coletiva para o

\footnotetext{
${ }^{167}$ Assim como o testamento - o qual foi responsável pelo desenvolvimento dos primeiros estudos acerca da autonomia privada (nesse sentido, cf., por todos, FERRI, Luigi. L'autonomia privata... Op. Cit., p. 345).

${ }^{168}$ Cf. CANOTILHo, Joaquim José Gomes. Direito Constitucional... Op. Cit., p. 996.

${ }^{169}$ Silva, Walküre Lopes Ribeiro da. Autonomia Privada Coletiva... Op. Cit., p. 143.

${ }^{170}$ Cf. capítulo 1, item 1.4.

${ }^{171}$ Emblemática, no tema, a obra de Luigi Ferri (FERRI, Luigi. L’autonomia privata... Op. Cit..

${ }^{172}$ Cf., por todos, GiUgni, Gino. Diritto Sindacale..., Op. Cit., p. 137.

${ }^{173}$ Fernandes, António Monteiro. Direito do trabalho... Op. Cit., p. 670.
} 
âmbito da autonomia privada, ao afirmar que "le parti possono liberamente determinare il contenuto del contratto nei limiti imposti dalla legge" e “(...) possono anche concludere contratti che non appartengano ai tipi aventi una disciplina particolare, purché siano diretti a realizzare interessi meritevoli di tutela secondo l'ordinamento giuridico". ${ }^{174}$

Por força de tal previsão legal, o ordenamento italiano passa a reconhecer a autonomia coletiva enquanto espécie da autonomia privada - diferenciada da autonomia individual por ser justificada pelo interesse coletivo, e não pelo interesse de cada um dos membros que compõem o sindicato. ${ }^{175}$ Hoje, entende-se que o fundamento de legitimação da autonomia privada coletiva pode ser extraído do art. 39 da Constituição italiana ${ }^{176}$ - o qual, ao afirmar que "i sindacati (...) possono, rappresentati unitariamente in proporzione dei loro iscritti, stipulare contratti collettivi di lavoro con efficacia obbligatoria per tutti gli appartenenti alle categorie alle quali il contratto si riferisce" consagra o conceito de "interesse coletivo" (ou social), a seguir explicitado. ${ }^{177}$

Ademais da legitimidade e natureza do interesse envolvido, entende-se que a autonomia coletiva difere da individual por limitar a capacidade individual de negociação pelas próprias partes, na medida em que as normas coletivamente acordadas corresponderiam a "padrões de conduta" impostos aos membros do grupo em suas relações individuais. ${ }^{178}$

Com efeito, sabe-se que a autonomia privada individual, fruto do período liberalista, não conseguiu compensar a desigualdade do trabalhador perante a superioridade econômica do empregador - razão pela qual o dirigismo contratual estatal acabou prevalecendo sobre a autonomia individual nas primeiras relações trabalhistas. ${ }^{179}$ Posteriormente, entretanto, o direito de associação permitiu a criação dos sindicatos, disseminando-se a ideia de que tais entes organizados estariam aptos a representar o

\footnotetext{
174 “As partes podem livremete determiner o conteúdo do contrato nos limites impostos pela lei" e "(...) podem também concluir contratos que não pertendem aos tipos que tenham uma disciplina particular, desde que sejam destinados a realizar interesses merecedores de tutela segundo o ordenamento jurídico" - tradução livre.

${ }^{175}$ SAntoro-Passarelli, Giuseppe. Dirito Sindacale... Op. Cit., p. 18.

${ }^{176}$ Santoro-Passarelli, Giuseppe. Dirito Sindacale... Op. Cit., p. 18; Giugni, Gino. Diritto Sindacale... Op. Cit., p. 137.

${ }^{177}$ A positivação da autonomia privada coletiva em Constituições europeias, aliás, mostra-se bastante frequente: na Constituição Portuguesa, vem prevista no art. $^{\circ} 56 .^{\circ} / 3$ e 4 (complementados pelos arts. $531 .^{\circ}$ e ss do Código do Trabalho), bem como no art. 57.\%/2; na Espanhola, no art. 37. No Brasil, a autonomia coletiva pode ser extraída do art. $8^{\circ}$, III, c/c o art. $7^{\circ}, \mathrm{XXVI}$, da $\mathrm{CF} / 88$ : o primeiro, reconhecendo a capacidade do sindicato de representar a categoria; o segundo, afirmando a força normativa das convenções e acordos coletivos de trabalho.

${ }^{178}$ Fernandes, António Monteiro. Direito do trabalho... Op. Cit., p. 688.

${ }^{179}$ NASCIMENTO, Amauri Mascaro. Compêndio de Direito Sindical... Op. Cit., p. 447.
} 
empregado na negociação de condições de trabalho, permitindo a adaptação de normas estatais às relações laborais in concreto.

Portanto, as normas criadas pela negociação coletiva acabaram impondose como standards à negociação individual, até hoje predominando o entendimento de que, no conflito entre contrato individual e contrato coletivo de trabalho, o primeiro apenas prevalecerá quando prescrever normas mais favoráveis ao prestador de serviços.

Assim, tradicionalmente, a relação entre autonomia privada individual e coletiva, no âmbito trabalhista, dá-se pela inderrogabilidade in peius da segunda pela primeira. No caso de violação dessa diretriz, a solução encontrada pelos ordenamentos jurídicos, em regra, é a substituição automática da cláusula individual pela coletiva. ${ }^{180}$

Finalizando a análise da autonomia privada coletiva, é preciso tecer breves considerações acerca de sua natureza jurídica, se de poder originário ou poder derivado - tema que permeia as discussões sobre o instituto desde os primórdios de sua elaboração doutrinária. Na feliz lição de Norberto Bobbio, trata-se de decidir se o poder de negociação dos atores sociais, evidenciado pela autonomia privada coletiva, deve ser considerado como resíduo de um poder normativo natural e privado, anterior ao Estado, ou como produto do poder originário estatal: no primeiro caso, reconhece-se plena capacidade aos particulares de criarem normas independentes, mas que serão aceitas pelo Estado; no segundo, entende-se que o Estado delega poderes aos particulares para regulamentarem interesses "num campo estranho ao interesse público". ${ }^{181}$

\footnotetext{
${ }^{180}$ Embora a grande maioria dos ordenamentos jurídicos adote referida solução (como Espanha, Portugal e Brasil), na Itália há grande divergência doutrinária a respeito do tema. Com efeito, conforme a seguir se demonstrará com mais vagar, durante o período corporativista, havia ampla regulamentação dos contratos coletivos de trabalho pela legislação italiana. Assim, a solução dos conflitos era pacífica: a cláusula considerada menos benéfica ao trabalhador, constante do contrato individual, era automaticamente substituída pela mais favorável, prevista no coletivo. Entretanto, desde a queda do regime corporativo, os contratos coletivos, salvo raras exceções, não mais encontram expressa previsão no texto legal italiano, tratando-se de construções da práxis das relações trabalhistas, sedimentadas pela jurisprudência desse país. Diante da inexistência de regulamentação específica, portanto, acaloram-se debates doutrinários sobre como resolver o problema do conflito entre negociação coletiva e individual, por vezes prevalecendo soluções estranhas a outros ordenamentos, como anterioridade ou especificidade da cláusula contratual (para estudo aprofundado de tais debates, recomenda-se a leitura de GIUGNI, Gino. Diritto Sindacale... Op. Cit., pp. 135137). De qualquer maneira, segundo ressaltam Marco Biagi e Michele Tiraboschi, é preciso reconhecer que a autonomia privada individual encontra diversos limites previstos constitucionalmente, já que o art. 41, da Constituição italiana, precisa que a iniciativa econômica privada "non può svolgersi in contrasto con l'utilità sociale o in modo da recare danno alla sicurezza, alla libertà, alla dignità umana" (não pode desenvolver-se em contraste com a utilidade social ou de forma a causar dano à segurança, à liberdade, à dignidade humana - tradução livre) - por tal razão, cada vez mais, vem cedendo espaço à negociação coletiva (BIAGI, Marco e TIRABOSCHI, Michele. Istituzioni di diritto del lavoro. Milano: Giuffrè, 2012, pp. 36-38).

${ }^{181}$ BobBio, Norberto. Teoria do Ordenamento Jurídico... Op. Cit., pp. 40-41.
} 
Conforme demonstrado, prevalece na doutrina italiana o entendimento de que a autonomia privada coletiva, especificamente no âmbito trabalhista, tem natureza de poder originário, não se tratando de simples delegação de capacidade normativa às classes sociais. ${ }^{182}$ Nesse sentido, as normas decorrentes da autonomia privada coletiva e as estatais ocupariam o mesmo patamar, ambas ostentando a condição de verdadeiras fontes de direitos.

Segundo Walküre Lopes Ribeiro da Silva, tal concepção apenas se firmou na Itália após a queda do modelo corporativista e promulgação da Constituição democrática de 1948. Como, até então, o sindicato era considerado ente de direito público, somente com a consolidação da democracia, "os doutrinadores passaram a negar que a atuação normativa dos trabalhadores e empregadores, coletivamente organizados, se desse pela via da delegação do poder normativo por parte do Estado", como antes apregoado pela concepção fascista. ${ }^{183}$ Ademais, o entendimento da autonomia privada enquanto poder originário decorreu da visão conflitualista das partes sociais, consagrada pela nova Constituição, opondo-se à concepção integrativa de Estado e sindicato, consolidada no regime anterior. ${ }^{184}$

No mesmo tom, manifesta-se a doutrina portuguesa. António Monteiro Fernandes, por exemplo, afirma que a capacidade normativa dos grupos profissionais não é resultado de simples "concessão" ou "delegação" de poder normativo estatal - ao contrário, "constitui um dado 'pré-constitucional' inerente à fisiologia das organizações socio-profissionais". ${ }^{185}$ Em outras palavras, o direito à negociação coletiva não é criado ou outorgado pelo legislador constitucional, mas simplesmente garantido por este.

Por óbvio, entretanto, não se trata de poder incondicionado: ao contrário, cabe à lei a definição da forma de seu exercício. Mas isso não significa que a lei confere "autorização" para a negociação coletiva, como se esta decorresse daquela; a legislação apenas fixa parâmetros para seu exercício, e não "autoriza" ou "ratifica" sua efetivação.

\footnotetext{
${ }^{182}$ A respeito, cf., entre outros, ICHINO, Pietro. Autonomia coletiva e principio di libertà della concorrenza... Op. Cit., p. 13; PERSIANI, Mattia. Dirittto Sindacale... Op. cit., p. 146; ToPO, Adriana. Legge e autonomia collettiva nel lavoro pubblico. Padova: CEDAM, 2008, p. 10; BIAGI, Marco e TIRABOSCHI, Michele. Istituzioni di diritto del lavoro. Op. Cit., p. 38; PESSI, Roberto. Ossservazioni sulla democrazia neocorporata (a proposito di un libro di Francesco Galgano). In PESSI, Roberto (org.). Europa e concertazione: modelli a confronto. Padova, CEDAM, 2009, p. 8.

${ }^{183}$ Silva, Walküre Lopes Ribeiro da. Autonomia Privada Coletiva... Op. Cit., p. 138.

${ }^{184}$ Silva, Walküre Lopes Ribeiro da. Autonomia Privada Coletiva... Op. Cit., pp. 138-139.

${ }^{185}$ FERnANDES, António Monteiro. Direito do trabalho... Op. Cit., p. 689.
} 
Não por outra razão, aliás, a Constituição portuguesa atribui à legislação ordinária a missão de regulamentar a "legitimidade sindical" e a "eficácia" dos acordos (Art. 56. \%4: "A lei estabelece as regras respeitantes à legitimidade para a celebração das convenções colectivas de trabalho, bem como à eficácia das respectivas normas"). De qualquer forma, reitere-se: em nenhum momento, a Constituição atribui à lei a capacidade de aceitar ou recusar a autonomia coletiva, mas tão-somente regulamentar aspectos essenciais (legitimidade e eficácia) a seu exercício.

No Brasil, destacam-se os ensinamentos de Ronaldo Lima dos Santos, para quem a própria história do desenvolvimento do sindicalismo (e, consequentemente, da autonomia privada coletiva) demonstra sua natureza de poder originário. ${ }^{186}$

De fato, conforme bem explicitado pelo autor, deve-se recordar que a autonomia coletiva foi primeiramente proibida, depois tolerada, até que, finalmente, seria reconhecida pelo Estado. Contudo, mesmo durante o período de proibição, a realidade social e as doutrinas que vigoravam impediram seu sufocamento pelo Estado, determinando sua sobrevivência, ainda que não reconhecida pelo ordenamento jurídico oficial. Daí porque, afirma Santos, a autonomia coletiva é realidade social, anterior ao surgimento do Estado, e, com seu reconhecimento, apenas ganhou objetividade, enquanto instituto jurídico, e maior expressão jurídico-formal. ${ }^{187}$ Trata-se, portanto, de típico poder originário de criação de normas jurídicas.

Não se podem ignorar, nada obstante, posicionamentos em sentido contrário, i.e., que atribuem à autonomia privada coletiva natureza de mero poder derivado do estatal.

Norberto Bobbio é um dos defensores de referida opinião. Segundo o autor, a autonomia privada tanto coletiva quanto individual, embora constitua ordenamento autônomo, encontra-se subordinada ao ordenamento oficial. Por tal razão, não há como se defender sua natureza de poder originário, tratando-se de mera fonte delegada da fonte estatal. $^{188}$

No mesmo sentido, o entendimento de Niccolò Abriani, para quem a autonomia privada, de maneira geral, não se basta em si mesma, devendo necessariamente apoiar-se "sulla garanzia coercitiva dello Stato per produrre pienamente i suoi effetti e

\footnotetext{
${ }^{186}$ SAnTOS, Ronaldo Lima dos. Teoria das normas coletivas. $2^{\mathrm{a}}$ edição. São Paulo: LTr, 2009, p. 144.

${ }^{187}$ SAntos, Ronaldo Lima dos. Teoria das normas coletivas... Op. Cit., p. 144.

${ }^{188}$ BobBio, Norberto. Teoria do Ordenamento Jurídico... Op. Cit., pp. 41-42.
} 
vedere garantite le sue pretese". ${ }^{189}$ Octavio Bueno Magano, nessa linha, afirma que, embora se trate de poder derivado, limitado pelo estatal, nem por isso deixa de ser poder genuíno "porque gera, motu proprio, normas jurídicas, não se resolvendo em mera faculdade de agir". ${ }^{190}$

De forma análoga, o caráter originário da autonomia privada coletiva tende a ser questionado diante de regimes corporativistas, quando - conforme ressaltado a capacidade negocial dos grupos sociais assume caráter publicista e integrativo perante as normas estatais. ${ }^{191}$ É o que ocorre, por exemplo, no Brasil: conforme bem ressalta Walküre Lopes Ribeiro da Silva, os resquícios corporativistas do modelo sindical brasileiro acabam por determinar a prevalência do entendimento que identifica a autonomia privada coletiva como espécie de poder derivado do estatal. ${ }^{192}$

No entanto, com a devida vênia, entende-se que o ocorrido nos regimes corporativistas deve ser interpretado como distorção do conceito de autonomia coletiva, na medida em que não se coaduna com a verdadeira gênese das organizações sindicais - e, portanto, não tem o condão de alterar a natureza jurídica de poder originário da autonomia coletiva.

Duas constatações corroboram o argumento. Inicialmente, retomando a lição de Ronaldo Lima dos Santos ${ }^{193}$, reitere-se que, se o sindicato é fruto da realidade social e continua atuando mesmo nos períodos de proibição, a aproximação entre ele e o Estado nos regimes corporativos é mero artificialismo concebido pelo legislador para exercer maior controle sobre a atividade sindical. Em segundo lugar, consoante já salientado, mesmo admitindo a natureza de poder originário da autonomia coletiva, cabe à lei delimitar sua atuação no caso concreto - porém, por óbvio, tal delimitação não representa qualquer alteração na natureza da autonomia coletiva, apenas tendo o condão de melhor disciplinar seu exercício.

\footnotetext{
189 "Sobre a garantia coercitiva do Estado para produzir plenamente seus efeitos e ver garantida suas pretensões" - tradução livre (ABRIANI, Niccolò. Diritto comerciale. Milano: Giuffrè, 2011, p. 540).

${ }^{190}$ MAGANO, Octavio Bueno. Direito coletivo e sociedade pluralista. In Revista do TST, 1991, disponível online em http://www.tst.jus.br/documents/1295387/b2753874-7ac1-48f5-8cee-3957c95e79b8, acesso em $02 / 11 / 2014$, às $22 \mathrm{~h}$.

${ }^{191}$ Fernandes, António Monteiro. Direito do trabalho... Op. Cit., p. 689.

${ }^{192}$ Silva, Walküre Lopes Ribeiro da. Autonomia Privada Coletiva... Op. Cit., p. 139.

${ }^{193}$ SAntos, Ronaldo Lima dos. Teoria das normas coletivas... Op. Cit., p. 144.
} 
Portanto, independentemente do regime em que se encontra inserida, não há dúvidas de que a autonomia privada coletiva tem natureza jurídica de poder originário - sendo assim adotada no decorrer do presente trabalho. 


\subsection{Interesse coletivo}

Um dos grandes óbices apontados pela doutrina contrária ao reconhecimento dos acordos e convenções coletivas enquanto fonte do Direito é o fato de que, nem sempre, suas previsões coincidem com as aspirações dos empregados e empregadores, individualmente considerados, que serão por elas abrangidos. Exemplifique-se, adentrando o tema ora em estudo: a se admitir a reforma, in peius, da legislação trabalhista pela negociação coletiva, estar-se-ia partindo do pressuposto de que este é o interesse de todos os trabalhadores atingidos pela alteração - o que, por óbvio, nem sempre é verdadeiro.

Por tal razão, a única forma de justificar a atuação das normas coletivas de trabalho é a partir da análise do conceito de "interesse coletivo". É esse conceito que permite diferenciar as entidades sindicais de outras associações civis ${ }^{194}$, bem como justificar a autonomia privada coletiva enquanto criadora de condições de trabalho.

Sempre houve dificuldades na determinação do conceito de interesse coletivo, já que, consoante bem ressalta Amauri Mascaro Nascimento, o número de pessoas envolvidas não se mostra suficiente a distinguir entre os dois tipos de interesses, os coletivos e os individuais. ${ }^{195}$ A corroborar tal argumento, o autor apresenta o seguinte caso hipotético: se vários trabalhadores são dispensados no mesmo dia, mas por motivos diversos, está-se diante de interesses individuais e dispensa também individual; ao contrário, se o são em virtude do mesmo motivo, vislumbrar-se-á interesse coletivo e, a depender desse motivo, dispensa coletiva. ${ }^{196}$

O exemplo acima deixa claro, portanto, não ser possível a determinação ex ante do que seria ou não interesse coletivo: ao contrário, qualquer interesse, ainda que aparentemente individual, poderá ser considerado coletivo se o grupo manifestar sua intenção nesse sentido.

Assim, faz-se necessária a identificação de outros critérios para aludida diferenciação, que vão desde a qualificação dos sujeitos até a natureza dos interesses

\footnotetext{
${ }^{194}$ SANTORO-PASSARElli, Giuseppe. Dirito Sindacale... Op. Cit., p. 17.

${ }^{195}$ Nascimento, Amauri Mascaro. Compêndio de Direito Sindical... Op. Cit., p. 56.

${ }^{196}$ Nascimento, Amauri Mascaro. Compêndio de Direito Sindical... Op. Cit., p. 57.
} 
envolvidos, passando por métodos de legitimação e/ou renúncia dos interesses individuais in concreto.

$A b$ initio, pode-se afirmar que interesse coletivo corresponde à compatibilização dos anseios dos membros representados por determinada entidade. Ao aderirem a referida entidade, os membros naturalmente despojam-se de interesses estritamente individuais em prol de reivindicações coletivas, que podem ou não lhes trazer vantagens diretas, mas certamente atendem às pretensões do grupo. ${ }^{197}$ Nas palavras de António Monteiro Fernandes, a ação coletiva traduz uma composição de interesses individuais no seio do grupo social, na medida em que "a organização profissional funciona (...) como um instrumento de racionalização das pretensões dos seus membros". 198

Ocorre, assim, transição do interesse individual para o do grupo: o interesse coletivo não é mero somatório dos interesses individuais dos membros ${ }^{199}$, uma vez que permanecem interesses divergentes no seio da vontade unitária (a qual será representada pelo sindicato). Em outras palavras, conforme Giuseppe Santoro-Passarelli, não se trata de interesse in rerum natura, e sim resultado de um acordo entre os pertencentes ao grupo, o que faz com que o interesse coletivo assuma natureza indivisível. $^{200}$

Por essa razão, parte da doutrina defende que a determinação do interesse coletivo depende do "sacrifício" ou mesmo da "autolimitação" do individual" ${ }^{201}$, sendo o ato de associação ao sindicato a expressão de verdadeira renúncia ao interesse pessoal, em troca das vantagens decorrentes da tutela coletiva.

Tal entendimento coincide, sobretudo, com a teoria do corporativismo italiano, já que serve de fundamento ao autoritarismo dos entes representativos do interesse coletivo, "em detrimento de qualquer possibilidade de respeito à autonomia individual e ao

\footnotetext{
197 Assim, e.g., enquanto o interesse do trabalhador individualizado poderá ser o aumento de sua remuneração, o interesse do grupo de trabalhadores daquela determinada categoria poderá ser a manutenção de empregos, ainda que com redução salarial - daí a autorização conferida pelo art. $7^{\circ}$, VI, da Constituição Brasileira, a seguir analisado.

${ }^{198}$ FERNANDES, António Monteiro. Direito do trabalho... Op. Cit., p. 691. Daí a peculiar afirmação do autor no sentido de que os sindicatos atuam como verdadeiros "cartéis da força de trabalho" (FERNANDES, António Monteiro. Direito do trabalho... Op. Cit., p. 691).

199 Segundo Otávio Pinto e Silva, "não se trata da soma de interesses individuais, mas sim da sua combinação, realizada de forma a compor uma totalidade indivisível: um interesse coletivo só pode ser satisfeito por um único bem, apto a atender às necessidades de toda a coletividade" (SILVA, Otavio Pinto e. Fontes do direito do trabalho... Op. Cit., p. 210).

${ }^{200}$ SANTORO-PASSARElli, Giuseppe. Dirito Sindacale... Op. Cit., p. 17.

${ }^{201}$ SANTORO-PASSARELLI, Giuseppe. Dirito Sindacale... Op. Cit., p. 18.
} 
indivíduo como tal". ${ }^{202}$ Como se pode perceber, nesse posicionamento, o interesse coletivo, em verdade, acaba por se confundir com o próprio interesse público (ou seja, o interesse Estatal), adquirindo viés publicista.

Todavia, rechaçando a teoria da renúncia, modernamente se tem defendido que o interesse coletivo envolve "seleção" ou "escolha" entre interesses diversos, a partir da determinação de prioridades, de modo que a preterição de determinados interesses seja instrumento da promoção de outros. ${ }^{203}$ Isso porque, conforme leciona Amauri Mascaro Nascimento, "a democracia admite um espaço maior entre os diferentes níveis de interesses do que os regimes políticos autoritários". ${ }^{204}$

Daí a afirmação de que a autonomia coletiva é instrumento de mera prevalência do interesse coletivo em detrimento do individual, e jamais de renúncia do segundo em favor do primeiro.

Diversas teorias buscam explicar as origens dessa prevalência. É preciso identificar, com efeito, os motivos que levam determinado trabalhador ou empregador a admitir que certa associação o represente, muitas vezes desconsiderando seu interesse puramente individual em defesa do todo.

Nesse sentido, merece relevo a teoria do mandato, difundida na década de 1950 pela doutrina italiana ${ }^{205}$ e ainda hoje aceita na grande maioria dos ordenamentos jurídicos. Por força de tal teoria, a prevalência do interesse coletivo sobre o individual é justificada pelo instituto civilista do mandato: o ato de associação ao sindicato lhe confere, automaticamente, poderes para celebrar contratos coletivos, os quais serão aplicados a todos ao associados.

É o que defende, por exemplo, Gino Giugni. Além de justificar o interesse coletivo, o mandato conferido ao sindicato explicaria a inderrogabilidade dos contratos coletivos de trabalho, já que o próprio mandato, nos termos dos arts. 1723 , co. 2 , e 1726 do Código Civil italiano, é irrevogável. ${ }^{206}$

Ainda, a prevalência do interesse coletivo sobre o individual poderia ser justificada pela teoria da instituição, já examinada ${ }^{207}$, segundo a qual a natureza do

\footnotetext{
${ }^{202}$ Nascimento, Amauri Mascaro. Compêndio de Direito Sindical... Op. Cit., p. 57.

${ }^{203}$ FERnANDES, António Monteiro. Direito do trabalho... Op. Cit., p. 693.

${ }^{204}$ Nascimento, Amauri Mascaro. Compêndio de Direito Sindical... Op. Cit., p. 57.

${ }^{205}$ Cf., por todos, Galantino, Luisa. Diritto sindacale. 14 edição. Torino: G. Giappichelli, 2006, p. 136.

${ }^{206}$ GIUGNi, Gino. Diritto Sindacale... Op. Cit., p. 137.

${ }^{207}$ Cf. capítulo I, item 1.3.
} 
sindicato enquanto instituição evidencia o consenso entre seus membros, restando autorizada, consequentemente, a regulamentação de condições de trabalho por tais entidades.

Alice Monteiro de Barros aponta diversas outras teorias que buscam perquirir a natureza jurídica das convenções coletivas - as quais, em última análise, também serviriam à justificação do poder do sindicato de defender o interesse coletivo. ${ }^{208}$ Assim, a teoria da personalidade moral e fictícia, que identifica os sindicatos com seus associados; a teoria do pacto social, que parte do pressuposto de que o indivíduo, ao entrar para o sindicato, celebra um pacto, submetendo-se à vontade coletiva; a teoria da representação legal, que dita que o poder de representação do sindicato decorre diretamente da lei; entre outras.

Embora as teorias acima mencionadas mostrem-se aptas a justificar a atuação sindical de defesa do interesse coletivo em ordenamentos europeus especialmente naqueles em que as convenções e acordos coletivos do trabalho somente se aplicam aos trabalhadores e empregadores filiados ao sindicato, como na Itália -, certamente apresentam dificuldades de implementação no Brasil.

Referidas dificuldades decorrem dos mais variados fatores. Inicialmente, por certo, advêm da organização obrigatória dos trabalhadores e empregadores em categorias, mantida pela Constituição de 1988 mesmo após a queda do regime corporativo. De fato, por força de tal imposição constitucional, as partes sociais não têm autonomia no que tange à escolha do sindicato que as representará - e, se não há autonomia, consequentemente inexiste a possibilidade de concessão de mandato.

Ademais, como se sabe, no Brasil, a aplicação das convenções coletivas de trabalho mostra-se obrigatória a todos os integrantes da categoria, sem possibilidade de afastamento de sua incidência pelas partes sociais. Some-se o fato de que os índices de sindicalização em território brasileiro - embora tenham apresentado franco crescimento nos últimos anos ${ }^{209}$ - ainda se mostram bastante reduzidos (gerando crise de legitimidade dos sindicatos).

\footnotetext{
${ }^{208}$ Barros, Alice Monteiro de. Curso de Direito do Trabalho... Op. Cit., pp. 994-999.

${ }^{209}$ Segundo os últimos dados publicados pelo IBGE - Instituto Brasileiro de Geografia e Estatística, que podem ser encontrados em sua página eletrônica (www.ibge.gov.br), a taxa de sindicalização, no Brasil, aumentou de $16,4 \%$ para $17 \%$ entre 2005 e 2011 .
} 
É difícil, assim, defender a existência de verdadeiro interesse coletivo se as partes abrangidas pelo instrumento coletivo sequer reconhecem ao sindicato a condição de interlocutor social, defensor de seus interesses.

Tais pressupostos, sem dúvida, devem ser levados em consideração por qualquer estudo que, como o presente, destine-se à remodelação do sistema de fontes trabalhistas, defendendo a prevalência do modelo negociado sobre o legislado - razão pela qual o tema será, a seguir, retomado. Por ora, basta reiterar o papel fundamental desempenhado pelo interesse coletivo na consagração da autonomia privada coletiva enquanto expressão máxima do Direito do Trabalho hodierno. 


\subsection{A natureza de fonte dos acordos e convenções coletivas de trabalho}

Superado o estudo dos pressupostos da negociação coletiva em sede laboral (i.e., autonomia privada coletiva e interesse coletivo), resta responder aos seguintes questionamentos: seriam os frutos de referida negociação - isto é, os acordos e convenções coletivas - verdadeiras fontes de Direito do Trabalho? Se não, qual seria sua natureza jurídica? Se sim, como determinar sua relação com as demais fontes laborais? Ainda, a resposta apresentada às perguntas anteriores também se aplica a ordenamentos de índole ou com resquícios corporativistas, como o do Brasil (em que as noções de autonomia privada coletiva e interesse coletivo encontram-se mais rarefeitas do que em modelos de plena liberdade sindical)?

Consoante já explicitado no início do presente capítulo, é senso comum na doutrina trabalhista a concepção de que a fonte negocial exerce papel fundamental na regulamentação das condições de trabalho. Todavia, é preciso aprofundar tal afirmação, a partir da análise pormenorizada dos frutos de referida fonte (i.e., os acordos e convenções coletivas de trabalho ${ }^{210}$ ) e sua interação com o direito estatal nos diversos ordenamentos jurídicos - para, assim, verificar se efetivamente lhes é concebida a força normativa inerente a qualquer fonte do Direito.

Antes de proceder a tal aprofundamento, entretanto, é necessário exame de ordem terminológica, acerca da denominação mais adequada para se referir aos frutos da negociação coletiva, se "acordos e convenções coletivas de trabalho" ou, simplesmente, "contratos coletivos".

\subsubsection{Questão terminológica: o "contrato coletivo de trabalho"}

Sabe-se que o ordenamento brasileiro, atualmente, refere-se às "convenções coletivas de trabalho" e "acordos coletivos de trabalho" como frutos da negociação coletiva. Entretanto, outra expressão também é encontrada, em doutrina e jurisprudência, para fazer referência a tais frutos: "contrato coletivo de trabalho".

\footnotetext{
${ }^{210}$ Lembrando que, nos termos do art. 611 da CLT, convenções coletivas de trabalho são celebradas entre sindicatos de categoria econômica e profissional, e se aplicam a toda a categoria; já acordos coletivos de trabalho envolvem o sindicato profissional e a empresa ou grupo de empresa, aplicando-se apenas aos empregados da empresa signatária. Quanto à expressão "contrato coletivo de trabalho", esta será analisada a seguir.
} 
Essa expressão apresenta, porém, significados diversos, a depender do ordenamento jurídico no qual se insere. Em Portugal, por exemplo, explica António Monteiro Fernandes que o gênero "convenção colectiva" contempla o "contrato coletivo" (em que a negociação é realizada por associações de ambos os lados, i.e., do empregado e do empregador), o "acordo coletivo" (em que intervém uma pluralidade de empregadores para diferentes empresas) e o "acordo de empresa" (de que é parte um só empregador para uma empresa ou estabelecimento). ${ }^{211} \mathrm{Na}$ Itália, ante a inexistência de regramento legal específico acerca da negociação coletiva, doutrina e jurisprudência utilizam-se indistintamente da expressão "contratto collettivo" para designar quaisquer acordos advindos da atuação sindical. ${ }^{212}$

No Brasil, a Consolidação das Leis do Trabalho (CLT), até 1967, também adotava referida expressão para designar os instrumentos decorrentes da atuação sindical, tanto que a antiga epígrafe do Título VI da Consolidação era, justamente, "Do contrato coletivo de trabalho". Contudo, o Decreto-lei 229/1967 substituiu aludida epígrafe por "Convenções Coletivas de Trabalho". A partir de então, convencionou-se denominar os instrumentos de negociação coletiva de "acordos" e "convenções", restando afastado o emprego da antiga expressão "contrato coletivo" para sua designação. ${ }^{213} 214$

Por tal razão, hoje em dia, no Brasil, a expressão "contrato coletivo" apresenta elevada carga axiológica, sendo utilizada pela doutrina quando se pretende defender reforma do modelo de relações de trabalho, com a "superação do corporativismo, compreendido como a estatalização do ordenamento, para a autonomia privada coletiva,

\footnotetext{
${ }^{211}$ FERnANDES, António Monteiro. Direito do trabalho... Op. Cit., p. 115.

${ }^{212}$ Conforme a seguir estudado com mais vagar.

213 A análise detalhada da utilização da expressão "contrato coletivo", no Brasil, será efetuada no capítulo 5, item 5.3 do presente trabalho.

${ }^{214}$ Importante ressaltar que as convenções e acordos coletivos de trabalho não se confundem com os "pactos sociais". Referidos instrumentos correspondem a "acordos macroeconômicos tripartites - entre governo, trabalhadores e empregadores - ou bilaterais - entre trabalhadores e empregadores -, também denominados entendimentos, acordos nacionais ou concertação social" (NASCIMENTO, Amauri Mascaro. Compêndio de Direito Sindical... Op. Cit., p. 453). Normalmente, referidos pactos são celebrados pelas centrais sindicais e têm conteúdo mais amplo do que as convenções e acordos coletivos, de ordem econômica, social ou política, envolvendo a ideia de colaboração entre atores sociais e o governo. Entes, porém, não detêm eficácia jurídica e, portanto, não podem ser considerados verdadeiras fontes de direito - sua eficácia é meramente programática. Octávio Bueno Magano aponta tendência de surgimento de pactos sociais em diversos países europeus - em nítida faceta neocorporativista das relações laborais. Em referidos pactos, governo e sindicatos apontam temas que devem ser abordados pelas convenções coletivas, como objetivo de combate à inflação e ao desemprego, diminuição da conflitividade entre os participantes, racionalização dos processos de negociação coletiva, etc. (MAGANO, Octávio Bueno. Liberalismo, corporativismo, pluralismo e neocorporativismo...Op. cit., p. 62).
} 
com maior espaço para os interlocutores sociais". ${ }^{215}$ Trata-se, consoante Maurício Godinho Delgado, de termo que representa "uma tentativa de se gestar um instrumento de negociação coletiva que fosse capaz de ultrapassar os limites da estrutura corporativista tradicional do Direito Coletivo no Brasil". ${ }^{216}$

A carga axiológica atualmente imposta, no Brasil, à denominação “contrato coletivo de trabalho" será analisada em outra ocasião. ${ }^{217}$ Por ora, e para os fins a que se destina o presente capítulo, tal expressão será utilizada como sinônima de acordos e convenções coletivas de trabalho, retirando-se qualquer carga valorativa de seu conceito.

\subsubsection{O contrato coletivo enquanto fonte: entendimentos doutrinários}

Superada a questão terminológica incidente e retomando os questionamentos propostos no início da exposição, deve-se, desde logo, ressaltar: é amplamente dominante, em doutrina e jurisprudência, o entendimento de que o contrato coletivo é verdadeira fonte do Direito do Trabalho, mostrando-se apto a criar normas jurídicas plenamente aplicáveis às partes sociais. Em outras palavras, entre as fontes privativas do Direito do Trabalho, destacam-se as convenções e acordos coletivos do trabalho, "não só como fonte de direito, mas também como produto de negociação". ${ }^{218}$

A justificar referido entendimento, encontra-se a moderna teoria normativa, segundo a qual não apenas a lei e o ato estatal podem ser considerados “norma". É o que se extrai, por exemplo, dos ensinamentos de Bobbio, para quem norma é proposição prescritiva, que contém em si um comando $^{219}$, e de Kelsen, o qual defende a existência de caráter normativo até mesmo nos contratos. ${ }^{220}$ A esse respeito, conforme bem leciona Miguel Reale, pouco importa ser o poder negocial sujeito aos limites da lei, "pois um raciocínio desse tipo obrigar-nos-ia a concluir pela tese extremada segundo a qual tãosomente a lei constitucional seria fonte de Direito...". 221

No mesmo sentido, o posicionamento de Amauri Mascaro Nascimento. Após realizar breve análise acerca da natureza jurídica das convenções coletivas, o autor

\footnotetext{
${ }^{215}$ Nascimento, Amauri Mascaro. Curso de Direito do Trabalho. 25 edição. São Paulo: Saraiva, 2010, p. 1389.

${ }^{216}$ Delgado, Mauricio Godinho. Curso de Direito do Trabalho... Op. Cit., p. 162.

${ }^{217}$ Cf. infra, capítulo 5, item 5.3.

${ }^{218}$ FernANDES, António Monteiro. Direito do trabalho... Op. Cit., p. 63.

${ }^{219}$ BobBIO, Norberto. Teoria da Norma Jurídica. São Paulo: EDIPRO, 2001, pp. 72-74.

${ }^{220}$ Kelsen, Hans. Teoria Pura do Direito... Op. Cit., p. 104.

${ }^{221}$ REALE, Miguel. Lições preliminares de Direito... Op. Cit., p. 180.
} 
salienta que "independentemente da natureza contratual ou regulamentar, a convenção coletiva é uma norma, desde que se dissocie o conceito de normas do conceito de lei ou ato estatal". ${ }^{222}$ Ainda, Joaquim José Gomes Canotilho, reconhecendo a condição de fonte das convenções e acordos coletivos de trabalho, afirma, inclusive, que tais instrumentos devem estar sujeitos a controle de constitucionalidade, já que "as convenções coletivas transportam normas juridicamente vinculativas sendo esta vinculatividade reconhecida pelos poderes públicos". 223

Por óbvio, entretanto, encontram-se posicionamentos contrários em doutrina, especialmente nos países onde os instrumentos da negociação coletiva não gozam de expressa previsão legal - como, por exemplo, a Itália.

O Código Civil italiano de 1942, promulgado durante o regime corporativista, foi responsável pela consagração do contrato coletivo enquanto fonte do Direito do Trabalho nesse país. Com efeito, aludido diploma inseriu o contrato coletivo na categoria das normas corporativas (art. 5 disp. prel. c.c.), enquadrando-o expressamente entre as fontes de direito disciplinadas pelo art. 1, disp. prel.. Segundo afirma Gino Giugni, houve atribuição, ao sindicato, de parte do poder normativo originário, ensejando a celebração de inúmeros contratos coletivos, sobretudo em âmbito estatal. ${ }^{224}$

O caráter normativo de referidos contratos evidenciava-se, ademais, pelo disposto no art. 2077 do Código Civil, o qual determinava a aplicação dos contratos coletivos a toda a categoria, identificada a partir da atividade econômica do empregador. Diante da eficácia erga omnes e da natureza publicista da negociação coletiva, assim, não havia qualquer discussão a respeito da condição de fonte de direito dos contratos coletivos.

Com a supressão do regime fascista, em 1944, os contratos coletivos corporativos já celebrados continuaram em vigor, assim como os artigos do Código Civil que reconheciam sua natureza jurídica de fonte. Porém, fez-se necessária nova regulamentação da negociação coletiva, agora inserida em sistema democrático e de plena liberdade sindical - a qual foi operada pelo já mencionado art. 39 , parágrafo $4^{\circ}$, da

\footnotetext{
${ }^{222}$ Nascimento, Amauri Mascaro. Compêndio de Direito Sindical... Op. Cit., p. 457.

${ }^{223}$ CAnotilho, Joaquim José Gomes. Direito Constitucional... Op. Cit., p. 996.

${ }^{224}$ GIUGNI, Gino. Diritto Sindacale... Op. Cit., 2012, p. 128.
} 
Constituição italiana ${ }^{225}$, considerado pela doutrina italiana o fundamento da autonomia coletiva e, consequentemente, da contratação coletiva. ${ }^{226}$

Consoante se extrai de aludido dispositivo, os contratos coletivos celebrados pelos sindicatos registrados teriam eficácia erga omnes, aplicando-se indistintamente a todos os membros da categoria. Tal eficácia, entretanto, acabou representando verdadeira sentença de morte ao dispositivo constitucional: o temor de retorno ao modelo corporativista e a resistência de sindicatos menores em atuar em sistema de contratação coletiva com eficácia erga omnes ensejaram a inaplicabilidade prática do art. 39, parágrafo $4^{\circ}$, da Constituição.

Colocou-se, então, o seguinte problema nas relações coletivas italianas: os contratos coletivos corporativos, celebrados antes da queda do regime, mantinham-se em vigor, com eficácia erga omnes e natureza de fontes do Direito $^{227}$; ao contrário, os contratos posteriores seriam celebrados sem qualquer amparo legal, dando margem a questionamentos quanto a sua eficácia subjetiva ${ }^{228}$ e natureza de fonte.

Atualmente, não há, no ordenamento italiano, qualquer regulamentação legal específica acerca dos contratos coletivos de trabalho - os únicos dispositivos legais que poderiam ser utilizados como fundamento jurídico de referido instrumento são os já

\footnotetext{
225 "I sindacati registrati hanno personalità giuridica. Possono, rappresentati unitariamente in proporzione dei loro iscritti, stipulare contratti collettivi di lavoro con efficacia obbligatoria per tutti gli appartenenti alle categorie alle quali il contratto si riferisce" ("Os sindicatos registrados têm personalidade jurídica. Podem, representados unitariamente na proporção de seus inscritos, estipular contratos coletivos de trabalho com eficácia obrigatória a todos os pertencentes às categorias às quais o contrato se refere" - tradução livre).

${ }^{226}$ SANTORO-PASSARELli, Giuseppe. Dirito Sindacale... Op. Cit., p. 15.

${ }^{227}$ Já que, segundo entendimento doutrinário dominante, os dispositivos do Código Civil de 1942 aplicam-se tão somente ao contratos coletivos corporativos (cf. GIUGNI, Gino. Diritto Sindacale... Op. Cit., p. 140).

${ }^{228}$ Diante da inaplicabilidade prática do art. 39 da Constituição, a solução encontrada pela legislação italiana para conferir eficácia erga omnes aos contratos coletivos celebrados após a queda do corporativismo foi sutil: a Lei Delegada n. 741, de 14 de julho de 1959 (denominada Lei Vigorelli), conferiu ao governo a capacidade de editar, dentro de um ano de sua entrada em vigor, decretos legislativos contendo normas de tratamento mínimo para cada categoria, baseando-se nas cláusulas de contratos coletivos já existentes na data de promulgação da lei. Em outras palavras: a despeito de não se reconhecer, diretamente, eficácia erga omnes dos contratos coletivos, esta foi indiretamente fixada mediante tais decretos legislativos. Embora inicialmente prevista para durar apenas um ano, a Lei acabou sendo renovada em 1960 - o que ensejou a profusão de decretos emanados pelo governo, chegando a totalizar mais de mil (GIUGNI, Gino. Diritto Sindacale... Op. Cit., p. 130). Sabe-se, entretanto, que há grandes diferenças entre os métodos da negociação coletiva e da legislação, razão pela qual não se mostrava adequada a solução da Lei Vigorelli. Assim, em 1962, a Corte Constitucional italiana reconheceu que o próprio art. 39 da Constituição já conferia eficácia erga omnes aos contratos coletivos de trabalho, desde que celebrados por entidades legítimas e observados os procedimentos previstos em lei - sendo desnecessária, portanto, qualquer atuação legislativa nesse sentido. Por tal razão, a renovação da lei foi considerada inconstitucional pela Corte Constitucional italiana, e não houve renovações posteriores (a respeito do tema, cf. GALANTINO, Luisa. Diritto sindacale... Op. Cit., p. 131). Porém, ressaltese mais uma vez: embora reconhecida, pela Corte Constitucional, eficácia erga omnes aos contratos celebrados no âmbito do art. 39 da Constituição, tais contratos não encontraram aplicabilidade prática na Itália, diante da já citada ineficácia do dispositivo.
} 
mencionados artigos do Código Civil e o art. 39 da Constituição. ${ }^{229}$ Ainda assim, é praxe entre as entidades sociais a celebração de contratos coletivos - os quais costumam ser denominados pela doutrina como "contratos de direito comum", eis que fundados em tipicidade meramente social ${ }^{230}$ e previstos exclusivamente pelo Código Civil. ${ }^{231}$

Tratando-se de contratos diferenciados daqueles disciplinados pelo art. 39 da Constituição italiana (os quais, como visto ${ }^{232}$, têm sua eficácia erga omnes reconhecida pela Corte Constitucional), prevalece o entendimento de que os contratos coletivos de direito comum aplicam-se apenas aos membros dos sindicatos signatários ${ }^{233}$, salvo mecanismos de extensão admitidos pelo direito comum, como comportamentos que demonstrem aceitação tácita das cláusulas por parte do empregador (e.g., quando este aplica o contrato coletivo mesmo sem estar vinculado a ele).

Porém, apesar de não regulamentados expressamente por lei, é certo que tais contratos são dotados de função normativa, ou seja, capacidade de determinar normas aplicáveis às relações contratuais que estão sendo e que serão desenvolvidas pelas partes. $^{234}$ Por isso, hodiernamente, pairam grandes discussões, em doutrina italiana, a respeito da natureza de fonte dos atuais contratos coletivos de direito comum.

Nesse sentido, há grandes defensores da ausência de caráter de fonte dos contratos coletivos - como, e.g., Gino Giugni, para quem as fontes do direito objetivo são expressões de um poder normativo que se impõe de forma heterônoma aos destinatários da norma, enquanto os contratos coletivos somente realizam a composição de interesses em conflito mediante o exercício da autonomia privada coletiva. ${ }^{235}$ Assim, tratar-se-ia, no máximo, de fontes de “direito comum” (i.e., sem qualquer previsão legal), faltando-lhes objetividade.

Na mesma linha, o entendimento de Dalfino Domenico, para quem o contrato coletivo não pode ser integralmente assimilado ao conceito de "contrato", em virtude da ausência de regulamentação legal. E, se não se assimila ao contrato, também não

\footnotetext{
${ }^{229}$ As articulações entre os diferentes níveis de negociação coletiva e os procedimentos de estipulação dos contratos coletivos, bem como sua duração, vêm regulamentados, apenas, pelo Protocolo de 23 de julho de 1993 - originado de negociações dos próprios atores sociais.

${ }^{230}$ GiUGNI, Gino. Diritto Sindacale... Op. Cit., p. 134.

${ }^{231}$ Galantino, Luisa. Diritto sindacale... Op. Cit., p. 129.

${ }^{232}$ Cf. supra, nota $n^{\circ} 180$.

233 Nesse sentido, em doutrina, cf. Galantino, Luisa. Diritto sindacale... Op. Cit., p. 135; em jurisprudência, cf. Cass. 30 luglio 2001, n. 10375; Corte cost. 26 giugno 1969, n. 105.

${ }_{234}$ Razão pela qual Gino Giugni os caracteriza como "contratos normativos" (GIUGNI, Gino. Diritto Sindacale... Op. Cit., p. 135).

${ }^{235}$ Giugni, Gino. Diritto Sindacale... Op. Cit., p. 133.
} 
pode ser enquadrado no conceito de "lei", restando alijado das fontes formais objetivas do direito. $^{236}$

Ainda, destaca-se o posicionamento de Luigi Mengoni, segundo o qual o contrato coletivo trata-se de contrato de direito comum e, sendo mera fonte de obrigações entre as partes, não pode ser reconduzido ao sistema das fontes de direito objetivo. ${ }^{237}$

Em posicionamento intermediário, Giuseppe Santoro-Passarelli defende a natureza de fonte dos contratos coletivos, sobretudo pelo fato de haver frequentes reenvios da lei à contratação coletiva, os quais "costituiscono un corpus normativo in cui fonte legale e fonte negoziale si intrecciano così strettamente che la funzione dela legge viene 'delegata' (...) al contratto collettivo". ${ }^{238}$ Contudo, entende o autor que se está diante de fonte meramente "extra ordinem", i.e., não inserida no esquema tradicional de fontes ${ }^{239}$, já que tal inserção dependeria da regulamentação legal do sistema de representatividade sindical (a fim de que, assim, possa identificar-se o sindicato apto a negociar direitos para determinada categoria, criando normas).

Por seu turno, Luisa Galantino, embora admitindo que o contrato coletivo não se encontra expressamente previsto no sistema formal das fontes jurídica, ressalta seu caráter de fonte do direito ao reconhecer que este "assumi efficacia regolativa dei rapporti di lavoro analoga a quella delle norme di legge". ${ }^{240}$ No mesmo sentido, a lição de Luigi Mariucci, o qual ressalta a natureza de "fonte superior" tanto da lei, quanto do contrato coletivo - ainda que este não se mostre aplicável a todos os integrantes da categoria. ${ }^{241}$

A jurisprudência, ainda, costuma aplicar aos contratos de direito comum a previsão contida no art. 2077 do Código Civil, para reconhecer sua natureza jurídica de fonte. Entretanto, tal aplicação extensiva tende a ser combatida pela doutrina, já que conforme antes salientado - aludido artigo apenas se refere aos contratos coletivos

\footnotetext{
${ }^{236}$ DOMENICO, Dalfino. La nuova giustizia del lavoro. Bari: Cacucci, 2011, p. 323.

${ }^{237}$ Mengoni, Luigi. Le fonti del diritto del lavoro in Italia. In BOLDT, Gerhard; DurAnd, Paul; HorION, Paul; Kayser, Armand; Mengoni, Luigi; MolenaAr, A. N. Le Fonti Del Diritto Del Lavoro. Comunità Europea del Carbone e dell'acciaio - Alta autorità, Luxemburgo, 1962, p. 149.

238 “constituem um corpo normativo no qual fonte legal e fonte negocial se misturam tão estreitamente que a função da lei é delegada (...) ao contrato coletivo" - tradução livre (SANTORO-PASSARELLI, Giuseppe. Dirito Sindacale... Op. Cit., p. 126).

${ }^{239}$ SANTORO-PASSARELli, Giuseppe. Dirito Sindacale... Op. Cit., p. 126.

240 "assume eficácia regulativa das relações de trabalho análoga àquela das normas legais" - tradução livre (Galantino, Luisa. Diritto sindacale... Op. Cit., p. 133).

${ }^{241}$ MARIUCCI, Luigi. Le fonti del Diritto del Lavoro - quindici anni dopo. Edizione aggiornata. Torino: G. Giappichelli, 2003, p. 13.
} 
corporativos, os quais diferem dos de direito comum porque expressamente elevados, por lei, à categoria de fonte jurídica. ${ }^{242}$

De qualquer maneira, recentes alterações legislativas parecem ter consagrado a concepção do contrato coletivo como fonte, no ordenamento italiano: o d. lgs. $\mathrm{n}^{\mathrm{o}} 40$, de 2 de fevereiro de 2006, introduziu, entre os motivos de recurso à Corte de Cassação (previstos pelo art. 360 do Código de Processo Civil italiano), a violação ou falsa aplicação dos contratos e acordos coletivos nacionais de trabalho - assimilando-a à violação ou falsa aplicação de normas jurídicas. Aparentemente, o legislador pretendeu equiparar o contrato coletivo à lei - ao menos sob o ponto de vista de sua aplicabilidade. ${ }^{243}$

Gino Giugni ressalta a importância prática da norma, na medida em que contratos coletivos de âmbito nacional tendem a ensejar diferentes interpretações e, consequentemente, um contencioso de massa envolvendo sua aplicação aos casos concretos. Assim, o legislador pede ajuda para a Corte de Cassação no que tange a aludida interpretação, garantindo a uniformização da jurisprudência. Aparentemente revendo seu posicionamento anterior sobre o tema, e finalizando seu raciocínio, o autor afirma que, de fato, a exigência de assegurar homogeneidade de direcionamentos interpretativos "deriva dal carattere astrato e generale della norma da applicare e dalla sua applicabilità ad una serie indeterminata di casi pratici, e non dalla sua natura eteronoma od autonoma". ${ }^{244}$

Como se vê, a despeito das discussões doutrinárias que sempre permearam o tema, a recente alteração legislativa operada pelo d. lgs. 40/2006 tende a promover maior unificação no que concerne ao entendimento do contrato coletivo enquanto fonte do direito laboral italiano.

Em países onde há expressa regulamentação legal da negociação coletiva, a aceitação das convenções e acordos coletivos de trabalho enquanto fontes do direito costuma ser tranquila. Assim ocorre, por exemplo, na Espanha, cuja exposição de motivos da Lei 11/1994 - responsável, como se verá a seguir, por relevantes modificações na disciplina da contratação coletiva - destaca a importância conferida à negociação enquanto fonte de direito, qualificando-a como "un instrumento fundamental para la

\footnotetext{
${ }^{242}$ A respeito do tema, cf. Galantino, Luisa. Diritto sindacale... Op. Cit., p. 133.

243 Nesse sentido, cf. o posicionamento de GALAntinO, Luisa. Diritto sindacale... Op. Cit., p. 134; RuSCIANO, Mario. La metamorfosi del contratto collettivo. In Riv. trim. dir. proc. civ., ano 2009, n. 01, p. 30 .

244 "deriva do caráter abstrato e geral da norma a aplicar e de sua aplicabilidade a uma série indeterminada de casos práticos, e não da sua natureza heterônoma ou autônoma" - tradução livre (GIUGNI, Gino. Diritto Sindacale. ... Op. Cit., p. 134).
} 
deseable adaptabilidad por su capacidad de acercamiento a las diversas y cambiantes situaciones de los sectores de actividad y de las empresas". ${ }^{245}$ Nesse sentido, consoante bem ressalta Jesús R. Mercader Uguina, "la garantía constitucional que se otorga a la fuerza vinculante de los convenios colectivos implica la atribuición a los mismos de una eficácia jurídica que se impone automaticamente a las relaciones de trabajo incluídas en su ámbito de aplicación". 246

Em Portugal, António Monteiro Fernandes sustenta que a convenção coletiva (e assim também o acordo coletivo) tem uma faceta negocial e uma faceta regulamentar. Pela primeira, sabe-se que a convenção resulta de um acordo obtido mediante negociação, por meio da qual se equilibram os interesses coletivos dos trabalhadores e dos empregadores envolvidos; porém, desse acordo, nascem normas jurídicas incidentes sobre os contratos individuais de trabalho, vigentes ou futuros - e, daí, a faceta regulamentar. ${ }^{247}$

Embora - continua o autor - qualquer convenção apresente ambas as facetas, cada uma delas prevalece em um momento diferente: na formação, intepretação e integração do acordo, prevalece a faceta negocial; de outra parte, as condições de eficácia das convenções são idênticas às da lei, razão pela qual esta pode ser considerada autêntica fonte de Direito. ${ }^{248}$

Na Alemanha, também não pairam dúvidas a respeito da natureza de fonte das convenções coletivas de trabalho, denominadas "Tarifverträge", “Tarifvereinbarungen" ou "Tarifbkommen'. De fato, segundo afirma Gerhard Boldt, as disposições dos contratos coletivos constituem lei em sentido material, já que podem ser objeto de controle jurisdicional e invocadas por qualquer membro das associações contratantes e, por vezes, mesmo por outros trabalhadores não filiados à associação. ${ }^{249}$

\footnotetext{
245 "Um instrumento fundamental para a desejável adaptabilidade por sua capacidade de aproximação às diversas e mutáveis situações dos setores de atividade e das empresas" - tradução livre.

246 “a garantia constitucional que se outorga à força vinculante dos convênios coletivos implica a atribuição a estes de uma eficácia jurídica que se impõe automaticamente às relações de trabalho incluídas em seu âmbito de aplicação" - tradução livre (UGUINA, Jesús R. Mercader. La silenciosa decadencia del principio de normas más favorable. In CIVITAS - Revista Española de Derecho del Trabajo, $\mathrm{n}^{\mathrm{o}} 109$, Enero-Febrero 2002, Madri, p. 30).

${ }^{247}$ FERnANDES, António Monteiro. Direito do trabalho... Op. Cit., p. 116.

${ }^{248}$ FERNANDES, António Monteiro. Direito do trabalho... Op. Cit., p. 116.

${ }^{249}$ BOLDT, Gerhard. Le fonti del diritto del lavoro in Germania In BOLDT, Gerhard; DuRAND, Paul; HorION, Paul; Kayser, Armand; Mengoni, Luigi; MolenaAr, A. N. Le Fonti Del Diritto Del Lavoro. Comunità Europea del Carbone e dell'acciaio - Alta autorità, Luxemburgo, 1962, p. 39.
} 
Na França, Paul Durand sustenta a existência de um "regulamento do trabalho com base contratual", na medida em que o direito estatal e o direito profissional constituem duas fontes distintas do Direito do Trabalho, combinadas pelo ordenamento francês no processo de formação desse ramo do Direito. ${ }^{250}$ No mesmo sentido, para Bernard Teyssié, o Direito do Trabalho francês é orientado pela negociação coletiva, na medida em que todo sindicato representativo detém legitimidade para celebrar acordos e convenções coletivas. $^{251}$

\subsubsection{A posição do ordenamento brasileiro}

No Brasil, a legislação não consagra, expressamente, o caráter de fonte das convenções e acordos coletivos do trabalho. Aliás, como se sabe, no ordenamento brasileiro, não há tradição de identificação das fontes do Direito por parte do legislação: ao contrário, o elenco de fontes normativas é atribuído à doutrina e à jurisprudência, diante da inexistência de dispositivo legal específico que contemple quais instrumentos seriam ou não aptos a normatizar relações jurídicas. ${ }^{252}$

Especialmente quanto às convenções e acordos coletivos de trabalho, a Constituição Federal, por certo, reconheceu a força normativa de tais instrumentos no art. $7^{\circ}$, XXVI; a CLT, por seu turno, positivou-os como aptos a regulamentar, em concreto, as relações laborais. Entretanto, em nenhum momento, são qualificados expressamente pelo ordenamento jurídico como fontes do Direito.

Todavia, deixando de lado viés estritamente formalista e atentando às peculiaridades do Direito do Trabalho - sobretudo no que tange a sua grande interação com a realidade social $^{253}$, é preciso analisar as fontes desse ramo do Direito sob

\footnotetext{
${ }^{250}$ DuRAND, Paul. Le fonti del diritto del lavoro in Francia... Op. Cit., pp. 120-121

${ }^{251}$ TEYSSIÉ, Bernard. Droit du travail - Relactions collectives. $4^{\mathrm{a}}$ Edição. Paris, Lexis Nexis, 2005, p. 343.

${ }^{252} \mathrm{E}$, daí, as inúmeras discussões a respeito do caráter normativo de determinados centros produtores de regras de conduta, como a jurisprudência, a doutrina, o contrato individual de trabalho, a sentença normativa, etc. Para referidas discussões, recomenda-se a leitura de Silva, Otavio Pinto e. Fontes do direito do trabalho... Op. Cit.; Delgado, Mauricio Godinho. Curso de Direito do Trabalho... Op. Cit., p. 142 e ss; Barros, Alice Monteiro de. Curso de Direito do Trabalho... Op. Cit., p. 81 e ss; Martins, Sergio Pinto. Direito do Trabalho. $30^{\text {a }}$ edição. São Paulo: Atlas, 2014, p. 39 e ss.

${ }^{253}$ Já se tendo afirmado que "o Direito do Trabalho mexe com a vida das pessoas, como poucas áreas do Direito o fazem" (Bettencourt, Pedro Ortins de. As novas ameaças ao direito do trabalho. In V Congresso Nacional de Direito do Trabalho - Memórias. Coimbra: Almedina, 2003, p. 96) e que "la Historia de los derechos sociales es (...) la Historia del reconocimiento de las necesidades básicas y de la organización de la sociedad para satisfacerlas" (CONTRERAS PELÁEZ, Francisco J.. Derechos sociales: teoría e ideología. Madrid: Tecnos, 1994, pp. 41-42).
} 
perspectiva mais concreta, considerando a importância da regulamentação da relação de trabalho pelos próprios interlocutores sociais. ${ }^{254}$

Nesse viés, Luigi Mariucci apresenta a seguinte situação hipotética: um trabalhador individualmente considerado presta serviços a empresa de médio porte, com taxa normal de sindicalização, e precisa conhecer qual a normativa aplicável a seu contrato de trabalho. Nesse caso, duas alternativas se podem apresentar: este empregado poderá ocupar uma posição forte no mercado laboral, que lhe permitirá negociar condições de trabalho individualmente, por força de seu próprio contrato ${ }^{255}$; ou poderá ser um empregado-padrão, sem força negociadora individual, subjugado ao poder do empregador. ${ }^{256}$ Enquanto, no primeiro caso, o trabalhador utilizará a disciplina prevista na lei e na negociação coletiva como mero parâmetro para a negociação individual, no segundo, está totalmente subjugado às normas positivadas pelo Estado e negociadas por seu sindicato - as quais são as únicas capazes de fazer frente à superioridade econômica e jurídica do empregador.

Aprofunde-se o quanto exposto no final do parágrafo anterior: na relação do empregado-padrão (i.e., sem capacidade negocial), destacam-se a lei e a contratação coletiva enquanto mecanismos de fixação das condições de trabalho. Nesse contexto, a lei aparece, tradicionalmente, como fonte imperativa, que disciplina uma proteção mínima, não passível de derrogação pelo contrato individual - e daí sua capacidade de limitação do poder do empregador. Porém, as convenções e acordos coletivos porventura aplicáveis ao trabalhador também acabam por desempenhar a mesma função: a fixação de mínimos iguais ou diferentes dos da lei - que deverão ser observados pelo tomador de serviços, em manifesta limitação do poder social exercido por este sobre o empregado. Destaca-se, dessa forma, a elevada importância desempenhada pelas cláusulas de convenções e acordos coletivos de trabalho na determinação, in concreto, das condições aplicáveis a determinado trabalhador.

Ademais, outro aspecto merece relevo nessa discussão: a tendência natural de migração de direitos previstos em convenções coletivas para a legislação estatal,

\footnotetext{
${ }^{254}$ Consoante José Barros Moura, no Direito do Trabalho, “de modo muito especial, a realidade econômica e social não pode ser ignorada pelo jurista, de tal maneira que ela modela o conteúdo das normas jurídicas aplicáveis às relações de trabalho" (MOURA, José Barros. A convenção colectiva entre as fonts de Direito do Trabalho. Coimbra: Almedina, 1984, p. 49).

${ }^{255}$ Em paradigma estritamente liberal, admitido apenas em casos excepcionais, de empregados com alto poder de negociação.

${ }^{256}$ MARIUCCI, Luigi. Le fonti del Diritto del Lavoro - quindici anni dopo... Op. Cit., pp. 10-11.
} 
bem como de superposição de previsões de convenções coletivas, mesmo na vigência da lei. $^{257}$

Inicialmente, é bastante comum que direitos originariamente consagrados em convenções e acordos coletivos de trabalho sejam incorporados gradualmente pela legislação estatal. No Brasil, exemplo emblemático de referido fenômeno é a gratificação natalina: a princípio decorrente dos costumes laborais e prevista em negociação coletiva, acabou-se tornando obrigatória por expressa disposição legal; da mesma forma, a garantia de emprego à gestante. Ainda, invocando caso mais recente, pode-se apontar o adicional de periculosidade à categoria dos vigilantes - o qual, após reiterada positivação em normas coletivas, foi regulamentado pela Lei 12.740/12.

De outra parte, o efeito contrário também é verdadeiro: diversas regras previstas em lei são alteradas in melius por convenção coletiva e, por tal razão, acabam caindo em verdadeiro desuso. Assim, por exemplo, o adicional de horas extras: assegurado pela Constituição Federal no percentual de 50\%, é frequentemente majorado por instrumentos coletivos, de forma a serem poucas as categorias que, atualmente, ainda se utilizam do adicional constitucional.

Segundo Amauri Mascaro Nascimento, esses dois movimentos em sentido inverso obedecem a razões diferentes: "uma aspiração de generalidade leva a lei a recolher das convenções coletivas alguns dos seus dispositivos, enquanto um imperativo de descentralização move a passagem de um direito da lei para as convenções coletivas". ${ }^{258}$ Explicita-se, portanto, a plena interação entre normas estatais e convencionais na formação do Direito do Trabalho - a qual não pode ser ignorada, ainda que o ordenamento legal não enquadre as convenções e acordos coletivos como verdadeiras fontes do Direito.

Ademais dos dois movimentos acima referidos, também merece relevo fenômeno comumente verificado na realidade social que corrobora aludida interação: muitas vezes, trabalhadores acreditam serem consagrados em lei direitos que, na verdade, somente encontram previsão em acordos e convenções coletivas de trabalho. É o que ocorre, e.g., com a garantia de emprego pré-aposentadoria e no caso de acidente ou doença que não tenha nexo com o trabalho - os quais, por serem frequentemente positivados em

\footnotetext{
${ }^{257}$ Para mais detalhes sobre o tema, cf. NASCIMENTO, Amauri Mascaro. Compêndio de Direito Sindical... Op. Cit., p. 446.

${ }^{258}$ Nascimento, Amauri Mascaro. Compêndio de Direito Sindical... Op. Cit., p. 452.
} 
textos de instrumentos normativos, acabam caindo no senso comum como "direitos do empregado", embora sem qualquer fundamentação legal.

Em síntese: se questionamentos podem existir quanto à condição de fonte do direito das convenções e acordos coletivos, no que tange ao viés estritamente acadêmico e formal, tais dúvidas não se justificam no plano substancial ${ }^{259}$, já que tais instrumentos apresentam a mesma finalidade sociológica da lei: limitar o poder individualmente exercido pelo empregador em relação ao empregado. ${ }^{260}$

Aliás, a discussão sobre a natureza de fonte das convenções e acordos coletivos de trabalho decorre da revalorização da própria autonomia individual, em detrimento da fixação geral e uniforme que deriva das normas estatais e convencionais revalorização que, por seu turno, decorre da perda de homogeneidade dos trabalhadores. ${ }^{261}$ A individualização dos interesses gera a necessidade de também os sindicatos individualizarem-se, regulamentando esses interesses específicos mediante instrumentos da negociação coletiva.

Com efeito, considerando que as bases do Direito do Trabalho apenas admitem a possibilidade de celebração de acordos mediante a participação do sindicato (ou seja, impedindo que o próprio empregado convencione com o empregador), nada mais lógico do que adaptar as convenções coletivas a essas particularidades, reconhecendo-se seu caráter de fontes do direito.

Outra conclusão não pode ser extraída do quanto acima exposto a não ser que, com relação à natureza jurídica, tanto a lei, como os contratos coletivos de trabalho podem ser considerados autênticas fontes do Direito - cabendo, neste momento, esmiuçarse as interações que se encerram entre elas. ${ }^{262}$

\footnotetext{
259 Como bem ressalta, aliás, Délio Maranhão, que interpreta a convenção coletiva como "contrato-atoregra", verdadeira fonte de direito que melhor atende às exigências da relação de trabalho (MARANHÃO, Délio. Direito do Trabalho. $7^{\mathrm{a}}$ Ed.. Rio de Janeiro: Fundação Getúlio Vargas, 1979).

${ }^{260} \mathrm{Na}$ inspirada lição de Luigi Mariucci, pode-se entender o conteúdo do contrato individual de trabalho como "un piccolo pianeta illuminato da diversi soli, ciascuno circondato da un proprio sistema: il sistema legislativo (...), il sistema della contratazione colletiva (...), il contrato individuale ed il potere del datore di lavoro" ("um pequeno planeta iluminado por diversos sóis, cada um circundado por um próprio sistema: o sistema legislativo (...), o sistema da contratação coletiva (...), o contrato individual e o poder do empregador" - tradução livre) (MARIUCCI, Luigi. Le fonti del Diritto del Lavoro - quindici anni dopo... Op. Cit., pp. 13-14).

${ }^{261}$ VICENTE PALACIO, Arantzazu. La negociación colectiva... Op. Cit., p. 259.

262 Por óbvio, entretanto, há inúmeras diferenças entre lei e contratação coletiva. Conforme leciona Luigi Mariucci, a diferença principal reside nos sujeitos criadores da fonte (já que, como se sabe, as convenções e acordos coletivos de trabalho inserem-se na categoria de fontes autônomas, pois constituem formas de autoregulação de interesses pelas próprias partes) e na sua abrangência, limitada aos trabalhadores e empregados
} 


\section{Fontes trabalhistas e princípio da norma mais favorável}

\subsection{O princípio da norma mais favorável enquanto orientador da relação entre fontes trabalhistas}

O Direito do Trabalho, desde suas origens, assenta suas bases em função tuitiva do trabalhador, buscando, mediante a promulgação de leis de caráter cogente, conferir superioridade jurídica a quem, no contrato de trabalho, é inferior economicamente. Por tal razão, especialmente após o inovador estudo de Américo Plá Rodriguez ${ }^{263}$, convencionou-se afirmar que a proteção é o princípio maior do Direito do Trabalho, sendo o subprincípio da "norma mais favorável" responsável pela interação e solução de conflitos entre as fontes desse ramo do Direito.

Já se demonstrou, nos capítulos precedentes, que o Direito do Trabalho é marcado por pluralidade de fontes normativas (leis, contratos coletivos, acordos e convenções internacionais, atos do Poder Executivo, etc.), as quais se aplicam simultaneamente às relações trabalhistas. É natural, assim, que surjam conflitos entre elas, e que o intérprete busque mecanismos para os solucionar, com intuito de conferir segurança jurídica ao sistema. ${ }^{264}$

Contudo, no Direito do Trabalho, é comum atribuir-se maior importância aos conflitos hierárquicos entre fontes, em comparação com outros ramos do Direito. ${ }^{265}$ Segundo Pedro Romano Martinez, tal importância deve-se, sobretudo, a dois fatores: em

pertencentes ao âmbito de atuação dos sindicatos signatários. Ademais, o procedimento da negociação coletiva é mais simplificado do que o da lei (muitas vezes, a depender do Estado em que se realiza, apenas submetido às exigências estabelecidas pelas próprias partes sociais) e, consequentemente, mais célere do que o processo legislativo. Ainda assim, o autor faz questão de ressaltar a natureza de "fonte superior" tanto da lei, quanto do contrato coletivo (cf. MARIUCCI, Luigi. Le fonti del Diritto del Lavoro - quindici anni dopo... Op. Cit., p. 13).

${ }^{263}$ RodrigueZ, Américo Plá. Princípios do Direito do Trabalho. $3^{\text {a }}$ Edição. São Paulo: LTr, 2004.

${ }^{264}$ Para alguns autores, o princípio da norma mais favorável, além de representar método de solução de conflitos entre fontes laborais, corresponde, também, a uma concepção original da norma no Direito do Trabalho, na medida em que é capaz de lhe conferir natureza imperativa - mas não imperatividade absoluta, e sim imperatividade que cede espaço à regra mais favorável ao trabalhador. A respeito, cf. VIGNEAU, Christophe. Le principe de faveur dans le régime du temps de travail en droit comparé In LAULOM, Sylvaine. Recomposition des systèmes de représentation des salariés en Europe. Université de Saint-Etienne, 2005, p. 254 e ss.

${ }^{265}$ A respeito, cf. Nascimento, Amauri Mascaro. Curso de Direito do Trabalho... Op. Cit., pp. 508 e ss. 
primeiro lugar, à já mencionada multiplicidade de fontes laborais, reiterando-se que, para além das fontes do direito comum, ao Direito do Trabalho acrescem-se instrumentos de regulamentação coletiva; e, em segundo, à proveniência diversa dessas várias fontes normativas, que podem ter sua origem no Estado, no domínio internacional, ou advir da própria vontade das partes (exteriorizada pelas entidades sindicais e associações de empregadores). ${ }^{266}$

No mesmo sentido, para Amauri Mascaro Nascimento, a maior relevância do tema no Direito do Trabalho relaciona-se ao fato de que este se destina a resolver as relações entre trabalhadores e empregadores segundo um sentido social, i.e., de melhoria das condições de vida do trabalhador - e esse aspecto teleológico não pode ser ignorado na análise da hierarquia das normas jurídicas trabalhistas. ${ }^{267}$

Daí porque, consoante bem salienta Otávio Pinto e Silva, enquanto para o Direito em geral, os critérios de solução dos conflitos entre normas são os da superioridade ou antiguidade, "para o Direito do Trabalho, essa matéria encontra solução diferenciada, por meio da aplicação do princípio da 'norma mais favorável'”, o qual determina que, no caso de conflito entre normas oriundas de fontes de produção de diferente hierarquia, prevalece a mais favorável ao trabalhador, salvo disposição proibitiva de norma derivada de fonte superior. ${ }^{268}$

É preciso, portanto, esmiuçar o conceito, bem como a abrangência, do mencionado princípio da norma mais favorável (por vezes também denominado "princípio do favor" ou "favor laboratoris") $)^{269}$ - principalmente para determinar sua importância na interação das fontes trabalhistas e na contraposição dos modelos negociado e legislado. ${ }^{270}$

No entender de Américo Plá Rodriguez, o estudo dos princípios mostrase de especial relevância para o Direito do Trabalho, tendo em vista a permanente evolução

\footnotetext{
${ }^{266}$ MartineZ, Pedro Romano. Direito do Trabalho. $3^{\text {a }}$ edição. Coimbra: Almedina, 2006, p. 259.

${ }^{267}$ NASCIMENTO, Amauri Mascaro. Curso de Direito do Trabalho... Op. Cit., p. 510. O autor ressalta, ainda, que, no Direito do Trabalho, não é adequado utilizar-se o termo "hierarquia entre leis", e sim "hierarquia entre normas", já que este se mostra mais abrangente, compreendendo também as fontes nãoestatais.

${ }^{268}$ SILVA, Otavio Pinto e. Fontes do direito do trabalho... Op. cit., p. 206.

${ }^{269}$ Expressões que, segundo Christophe Vigneau, pertencem à linguagem dos juristas, e não da legislação, já que nenhum dispositivo legislativo ou constitucional as consagra expressamente (VIGNEAU, Christophe. Le principe de faveur dans le régime du temps de travail en droit comparé... Op. Cit., pp. 251-252).

${ }^{270} \mathrm{Com}$ intuito de delimitação da pesquisa, é importante ressaltar que não se fará análise detalhada a respeito dos princípios gerais do Direito, nem tampouco dos princípios específicos do Direito do Trabalho, enfocando-se o estudo no princípio da norma mais favorável, apenas. De qualquer maneira, para melhor apreciação de ambos os temas, recomenda-se a leitura da célebre obra de Américo Plá Rodriguez já citada no presente texto (Rodriguez, Américo Plá. Princípios do Direito do Trabalho... Op. Cit.).
} 
e o aparecimento recente desse ramo do Direito. ${ }^{271}$ Segundo o autor, "o Direito do Trabalho necessita apoiar-se em princípios que supram a estrutura conceitual, assentada em séculos de vigência e experiência possuída por outros ramos jurídicos”, sobretudo por se tratar de ciência jurídica fragmentária e com tendência para o concreto, constituindo "direito em constante formação". 272

Entre os princípios informadores do Direito do Trabalho, nesse sentido, destaca-se o princípio da proteção. Hoje invocado indistintamente por doutrina, jurisprudência e, até mesmo, legislação ${ }^{273}$, referido princípio deriva das próprias origens do Direito do Trabalho, pois revela a necessidade de se conferir superioridade jurídica à parte que, no contrato de trabalho, é inferior economicamente, em uma relação marcada por igualdade meramente formal. Segundo João Leal Amado, o Direito do Trabalho consiste em ordenamento de caráter protetivo e compensador da assimetria típica da relação laboral, desempenhando função tuitiva quanto ao trabalhador assalariado, cumprida por meio de normas que possuem natureza relativamente imperativa. ${ }^{274}$

Não por outra razão, ao conceituar o Direito Social em aula inaugural de Legislação Social na Faculdade de Direito da Universidade de São Paulo, Cesarino Junior já ressaltava que o objetivo das leis sociais é a proteção ao economicamente fraco, com a finalidade mediata de "assegurar a paz social, o interesse geral, o bem comum". ${ }^{275}$

O princípio da norma mais favorável, no entender de Plá Rodriguez, corresponde a uma das formas de expressão do princípio de proteção. ${ }^{276} \mathrm{Em}$ simples conceituação, o princípio determina que, caso haja mais de uma norma aplicável ao caso

\footnotetext{
${ }^{271}$ A respeito, interessante ponderação é apresentada por Arion Sayão Romita: se os princípios são estudados para afirmar a autonomia cientifica de determinada ciência jurídica, e o Direito do Trabalho já é indubitavelmente autônomo, seria realmente necessário dar tamanha importância aos princípios trabalhistas? Porém, o mesmo autor ressalta que "a preocupação dos estudiosos que se lançam à tarefa de enumerar os princípios revela, antes, a necessidade de tomar posição (sociológica, política e fílosófica) em face das transformações que o Direito do Trabalho vem experimentando, como reflexo da adaptação da superestrutura jurídica às novas realidades" (RomitA, Arion Sayão. O Princípio da Proteção em Xeque. Disponível online em http://www.planalto.gov.br/ccivil_03/revista/Rev_36/artigos/Art_Arion.htm. Acesso em 17.10.11, às 16h30min.)

${ }^{272}$ Rodriguez, Américo Plá. Princípios do Direito do Trabalho. 3a Ed. São Paulo: LTr, 2004, p. 9. Retomem-se, aqui, as ponderações já apresentadas a respeito da interação do Direito do Trabalho com a realidade social (cf. supra, capítulo 2, item 2.4.3).

${ }^{273}$ Já que, conforme demonstrado a seguir, há expressa previsão legal de referido princípio na grande maioria dos ordenamentos jurídicos.

${ }^{274}$ AMADO, João Leal. Contrato de Trabalho. $2^{\text {a }}$ Ed. Coimbra: Wolters Kluwer Portugal/Coimbra Editora, 2010 , p. 42.

${ }^{275}$ CESARINO JÚNIOR, A. F.. Direito social: denominação, conceito e conteúdo. In Revista da Faculdade de Direito da Universidade de São Paulo, v. 35, n. 1 (1939), p. 231.

${ }^{276}$ Rodriguez, Américo Plá. Princípios do Direito do Trabalho... Op. Cit., p. 45.
} 
concreto, deve-se escolher a mais favorável ao trabalhador, ainda que em detrimento dos critérios clássicos de hierarquia normativa. ${ }^{277}$

Em outras palavras, no Direito do Trabalho, o princípio da prevalência hierárquica da lei articula-se com a norma mais favorável, na medida em que a regra convencional pode afastar a aplicação da regra legal, desde que mais benéfica à parte hipossuficiente da relação trabalhista. ${ }^{278}$

Atribui-se à doutrina alemã a elaboração do princípio em comento (Günstigkeitsprinzip) - o qual, porém, era inicialmente aplicável apenas às relações envolvendo fontes coletivas e contrato de trabalho. ${ }^{279}$ Buscava-se, mediante tal critério de solução de conflitos, salvaguardar espaço de liberdade da autonomia individual diante da ação coletiva.

Posteriormente, o princípio seria estendido também às relações entre lei $\mathrm{e}$ contratação coletiva - o que ocorre, segundo Maria do Rosário Palma Ramalho, em decorrência de dupla concepção, que se enraizou ao longo da história do Direito do Trabalho: por um lado, o sistema normativo trabalhista é pautado em regras imperativas que têm por objetivo resguardar um mínimo de proteção ao trabalhador; por outro, os entes coletivos desenvolveram o entendimento de que "a tutela laboral passa pela evolução do sistema protetivo sempre num sentido progressivamente mais favorável aos trabalhadores e que não admite retrocessos". 280

Ressaltando a importância do princípio, Américo Plá Rodriguez afirma que "tem enorme transcendência prática, que faz recordar aquela que, na concepção do firmamento, teve em sua época a revolução copérnica". ${ }^{281}$ Jesús R. Mercader Uguina salienta que este, juntamente com o princípio da norma mínima, "ha constituido la coluna vertebral y pilar maestro sobre el que se ha assentado el sistema de fuentes laborales $(\ldots.){ }^{\prime 282}$

\footnotetext{
${ }^{277}$ Rodriguez, Américo Plá. Princípios do Direito do Trabalho... Op. Cit., p. 45.

${ }^{278}$ AMADO, João Leal. Contrato de Trabalho... Op. Cit., p. 42.

279 Para mais informações sobre o tema, cf. UGUINA, Jesús R. Mercader. La silenciosa decadencia del principio de norma más favorable... Op. Cit., p. 203.

${ }^{280}$ Ramalho, Maria do Rosário Palma. Direito do Trabalho. Parte I - Dogmática Geral... Op. Cit., p. 266.

${ }^{281}$ Rodriguez, Américo Plá. Princípios do Direito do Trabalho... Op. Cit., p. 46

282 "constituiu a coluna vertebral e o pilar sobre o qual se assentou o sistema de fontes laborais (...) - tradução livre” (Uguina, Jesús R. Mercader. La silenciosa decadencia del principio de norma más favorable... Op. Cit.). Nesse aspecto, é importante ressaltar que parte da doutrina espanhola faz distinção entre o princípio da norma mínima e a regra da norma mais favorável. Pelo primeiro, entende-se que a norma estatal prevê certo nível de tutelas que pode ser melhorado, mas não piorado (tratar-se-ia da inderrogabilidade relativa);
} 
Por óbvio, o conflito entre normas no Direito do Trabalho também segue a hierarquia preconizada por outros ramos do direito. Entretanto, o princípio da norma mais favorável implica mitigação (ou verdadeira inversão) da hierarquia tradicional das normas jurídicas, de maneira que o topo da pirâmide entre as normas trabalhistas não necessariamente será a Constituição Federal, e sim a mais favorável entre as diferentes normas em vigor. ${ }^{283}$

Amauri Mascaro Nascimento, bem sintetizando a questão, leciona que, ao contrário do direito comum, a pirâmide que se forma entre as normas trabalhistas não terá como vértice a Constituição, a lei federal ou as convenções coletivas de modo imutável - ao contrário, os níveis normativos se alternam em constante modificação, a depender de sua maior ou menor favorabilidade ao trabalhador. Em suas palavras, "o vértice da pirâmide da hierarquia das normas trabalhistas será ocupado pela norma aplicável no caso concreto em se tendo como tal a que resultar do ordenamento jurídico interpretado com um sistema". 284

Trata-se, portanto, de manifesta regra de competência, critério de atribuição de poder à norma mais benéfica ao trabalhador, independentemente de esta se encontrar em hierarquia superior ou inferior. No entender da doutrina majoritária ${ }^{285}$, o princípio da norma mais favorável promove manifesta relativização da hierarquia tradicional das normas jurídicas, para fazer prevalecer aquela que mais benefícios

pelo segundo, deve prevalecer a norma com melhores condições aos trabalhadores. Ojeda Avilés critica referida distinção, afirmando que, em verdade, apenas existe um critério, "que seleccionará a la norma estatal cuando contenga las condicciones más altas, o bien preferirá lo establecido en el convenio o el contrato, si éstos aportan la oferta mejor" ("que selecionará a norma estatal quando contenha as condições mais altas, ou preferirá o estabelecido no convênio ou no contrato, se estes contêm a oferta melhor" tradução livre - OJEDA AVILÉS, Antonio. Compendio de derecho sindical. $2^{\mathrm{a}}$ edição. Madri: Tecnos, 2012, p. 27). Em Portugal, a distinção é aceita pela quase totalidade da doutrina: nas palavras de Jorge Leite, as normas trabalhistas típicas seriam constituídas por uma "regra jurídica explícita impositiva" e por uma "regra jurídica implícita permissiva", aquela vedando a redução do mínimo estabelecido e esta permitindo sua alteração in melius - portanto, o princípio da norma mínima deve entender-se não como regra de aplicação, mas como técnica de regulação (LEITE, Jorge. "Código do Trabalho - algumas questões de (in) constitucionalidade" In Questões Laborais, ano X, $\mathrm{n}^{\circ}$ 22, 2003, pp. 245-278). Para Milena Silva Rouxinol, "os dois princípios devem ser percebidos conjuntamente, uma vez que este último [norma mínima] oferece as condições de atuação do primeiro [norma mais favorável]”. (RouXINOL, Milena Silva. O princípio do tratamento mais favorável nas relações entre a lei e a convenção colectiva de trabalho. In Questões Laborais, Ano XIII, no 28, 2006, Coimbra Editora, pp. 159-190). No presente trabalho, não se apegará a aludida distinção, entendendo-se que a norma mínima é mera manifestação do princípio da norma mais favorável.

283 A respeito, cf. UGUINA, Jesús R. Mercader. La silenciosa decadencia del principio de norma más favorable... Op. Cit., p. 20.

${ }^{284}$ Nascimento, Amauri Mascaro. Curso de Direito do Trabalho... Op. Cit., p. 512.

${ }^{285}$ Em sentido contrário, o posicionamento de Pedro Romano Martinez, a seguir exposto com mais detalhes. (MartineZ, Pedro Romano. Direito do Trabalho... Op. Cit.). 
apresenta ao trabalhador - transformando, portanto, a norma superior em regra meramente dispositiva quando em confronto com regra inferior mais favorável. ${ }^{286}$

Para Nelson Mannrich, não se trata apenas de relativizar a problemática da hierarquia das normas trabalhistas, considerando superior a mais favorável, e sim de "dar efetividade ao comando constitucional de garantir aos trabalhadores um núcleo básico, entre outros direitos, com vistas à melhoria da condição social do trabalhador, mesmo porque nesse rol encontram-se os acordos e convenções coletivas". Em outras palavras, é possível que ocorra avanço na conquista dos direitos dos trabalhadores por meio da negociação coletiva, "servindo a lei como referência, não como freio". ${ }^{287}$

Ainda assim, é importante ressaltar que, conforme salienta Américo Plá Rodriguez, não ocorre verdadeira derrogação da norma pela outra mais favorável: a norma legal menos favorável de uma convenção coletiva, por exemplo, não fica revogada, porquanto continua produzindo seus efeitos em favor de todos aqueles trabalhadores não compreendidos pela outra norma, de hierarquia inferior, porém mais favorável. Portanto, não se pode falar em verdadeira derrogação - quando muito, verificar-se-ia inoperância parcial, na grande maioria das vezes, da norma menos favorável. ${ }^{288}$

É mister ressaltar, finalmente, que o princípio da norma mais favorável não se confunde com o do in dubio, pro operario - outra manifestação do princípio da proteção, identificada por Américo Plá Rodriguez. ${ }^{289}$ Com efeito, enquanto o primeiro consoante acima ressaltado - envolve regra de competência, consagrando soluções para o conflito entre normas, o segundo é critério de interpretação e aplicação da norma em concreto.

Dito de outro modo, o in dubio, pro operario manifesta-se quando uma única norma, aplicável a determinado caso concreto, apresenta duas ou mais interpretações (cabendo ao operador do direito selecionar a mais benéfica ao trabalhador);

\footnotetext{
${ }^{286}$ UguinA, Jesús R. Mercader. La silenciosa decadencia del principio de norma más favorable... Op. Cit., pp. 20-21.

${ }_{287}^{28}$ MANNRICH, Nelson. Relações entre legislado e negociado... Op. Cit..

${ }^{288}$ Rodriguez, Américo Plá. Princípios do Direito do Trabalho... Op. Cit., p. 52. No mesmo sentido, o posicionamento de Walküre Lopes Ribeiro da Silva, para quem "não haveria a substituição de uma norma por outra, como sustenta Bonnechère, mas a aplicação de ambas, pois a norma mais favorável de categoria inferior contém em si as condições previstas em normas de categoria superior”. Tal raciocínio, segundo a autora, permite concluir que não há inderrogabilidade relativa: "esta será sempre absoluta, uma vez que tanto a norma mais favorável como a menos favorável são aplicadas, pois uma está contida na outra" (SILVA, Walküre Lopes Ribeiro da. Autonomia Privada Coletiva... Op. Cit., p. 151).

${ }^{289}$ Segundo leciona Américo Plá Rodriguez, o in dubio pro operario é o "critério segundo o qual, no caso de que uma norma seja suscetível de entender-se de vários modos, deve-se preferir a interpretação mais favorável ao trabalhador" (Rodriguez, Américo Plá. Princípios do Direito do Trabalho... Op. Cit., p. 45).
} 
a norma mais favorável atua quando há duas ou mais normas igualmente aplicáveis ao caso concreto, devendo ser feita opção por uma delas. ${ }^{290}$

Como se vê, assim, o favor laboratoris envolve a conjugação de fontes trabalhistas - especialmente quando, entre elas, existe conflito no espaço - e suas relações com o contrato de trabalho in concreto. Porém, segundo Christophe Vigneau, longe de se reduzir a simples técnica de relacionamento entre regras, o princípio possui outra dimensão axiológica cardinal para a própria representação do Direito do Trabalho, pois fornece "un des ressorts de la rationalité normative propre à cette branche du droit". ${ }^{291}$

Segundo Maria do Rosário Palma Ramalho, o recurso ao favor laboratoris, no Direito do Trabalho, pressupõe duas operações técnicas prévias: a) a classificação das normas sobre as quais o princípio poderá incidir; e b) a operação de comparação entre fontes, para determinar qual a mais favorável, a ser aplicada ao caso concreto. ${ }^{292}$ Para o escopo do presente trabalho, interessa apenas a primeira operação, tendo em mente a natureza de fonte das normas coletivas de trabalho. ${ }^{293}$

\footnotetext{
${ }^{290}$ Opinião contrária é a de Maurício Godinho Delgado, para quem a função interpretativa encontra-se dentro do princípio da norma mais favorável (Delgado, Mauricio Godinho. Curso de Direito do Trabalho... Op. Cit.,pp. 194-195).

291 "um dos recursos da racionalidade normativa própria a esse ramo do direito" - tradução livre (VIGNEAU, Christophe. Le principe de faveur dans le régime du temps de travail en droit comparé... Op. Cit., pp. 250251).

${ }^{292}$ Ramalho, Maria do Rosário Palma. Direito do Trabalho. Parte I - Dogmática Geral... Op. Cit., p. 269.

${ }^{293}$ Entretanto, caso seja de interesse do leitor o estudo dos métodos de comparação das normas jurídicas (teoria da acumulação, do conglobamento, e do conglobamento limitado), para determinação da norma mais favorável entre elas, recomenda-se a leitura, além da própria Maria do Rosário de Palma Ramalho (Ramalho, Maria do Rosário Palma. Direito do Trabalho. Parte I - Dogmática Geral... Op. Cit., p. 272), de: Martinez, Pedro Romano. Direito do Trabalho... Op. CIt., pp. 264-65; OJeda AvilÉs, Antonio. Compendio de derecho sindical... Op. Cit., pp. 32-33; Delgado, Mauricio Godinho. Curso de Direito do Trabalho... Op. Cit., p 194 e ss; entre outros.
} 


\subsection{O princípio da norma mais favorável na legislação}

O princípio da norma mais favorável, embora inicialmente elaborado pela doutrina trabalhista, encontra positivação legal em diversos ordenamentos jurídicos entre os quais, por certo, destaca-se o português.

De fato, em Portugal, a antiga Lei do Contrato de Trabalho (LCT), de 1967, estabelecia em seu art. 13. ${ }^{\circ}$, n. ${ }^{\circ} 1$ que "as fontes de direito superiores prevalecem sempre sobre as fontes inferiores, salvo na parte em que estas, sem oposição daquelas, estabelecem tratamento mais favorável para o trabalhador". Referido dispositivo era complementado pelo art. $6^{\circ}$ da Lei dos Instrumentos de Regulamentação Colectiva (LRCT, Decreto-Lei n. ${ }^{\circ}$ 519-C1/79), segundo o qual as convenções coletivas não poderiam "contrariar as normas legais imperativas" ou "incluir qualquer disposição que importe para os trabalhadores tratamento menos favorável do que o estabelecido por lei”.

O favor laboratoris, aliás, era o norte de todo o sistema de fontes laborais em referido diploma: o art. $15 .^{\circ}$ da LRCT estabelecia que os direitos adquiridos durante a vigência de determinada convenção coletiva de trabalho só poderiam ser pontualmente reduzidos por novo instrumento de regulamentação coletiva e, ainda, se aludido instrumento fosse globalmente mais favorável do que o anterior; o art. $14 .^{\circ}$ estipulava que o contrato de trabalho somente poderia afastar normas legais e cláusulas de instrumento de regulamentação coletiva de trabalho para estabelecer regime mais favorável ao trabalhador; o art. 14. ${ }^{\circ}$, n. 2 b indicava o favor laboratoris como critério de solução de conflitos na concorrência entre duas convenções coletivas de trabalho; finalmente, eram comuns referências ao princípio do favor laboratoris em normas de direito intertemporal, visando a salvaguardar regimes mais favoráveis previstos em lei anterior.

Em 2003, entretanto, ocorre verdadeira revolução em tal orientação normativa.

Com efeito, o Código do Trabalho de 2003 contempla severa limitação ao princípio da proteção, especificando, no art. $4^{\circ}$, n. $^{\circ} 1$, que "as normas deste Código podem, sem prejuízo do disposto no número seguinte, ser afastadas por instrumento de regulamentação colectiva de trabalho, salvo quando delas resultar o contrário". No mesmo sentido, o art. 533. ${ }^{\circ}-$ sucessor do supramencionado art. $6 .^{\circ}$ da Lei dos Instrumentos de 
Regulamentação Colectiva -, o qual, a despeito de continuar a prescrever que as convenções coletivas não poderiam "contrariar as normas legais imperativas", deixa de acrescentar que aquelas tampouco podem incluir qualquer disposição com tratamento menos favorável para o trabalhador em relação ao estabelecido por lei.

Embora o art. $4 .^{\text {o }}$ venha previsto sob a epígrafe "Princípio do tratamento mais favorável", consagra mitigação a tal princípio, ao permitir sejam normas do Código do Trabalho afastadas pela negociação coletiva, ainda que in peius, exceto quando o legislador tenha proibido expressamente o afastamento. ${ }^{294}$ Como salienta Pedro Romano Martinez, essa proibição pode tanto ser absoluta - caso das normas imperativas de conteúdo fixo, que, por conterem valores de ordem pública, não admitem qualquer derrogação, in melius ou in peius - quanto relativa - como, e.g., nas normas parcialmente imperativas, que apenas admitem derrogação in melius. ${ }^{295}$

A postura do art. $4 .^{\circ}$ do $\mathrm{CT} / 2003$ seria, posteriormente, repetida na reforma do Código do Trabalho, ocorrida em 2009. Com efeito, o art. 3. ${ }^{\circ}$ de aludido diploma - agora sob a epígrafe "Relações entre fontes de regulação" - em princípio dispõe que "as normas legais reguladoras de contrato de trabalho podem ser afastadas por instrumento de regulamentação colectiva de trabalho, salvo quando delas resultar o contrário", analogamente ao diploma anterior (número 1). Em seguida (número 3), porém, especifica as matérias que apenas admitem derrogação in melius pela negociação coletiva, a saber: a) Direitos de personalidade, igualdade e não discriminação; b) Proteção na parentalidade; c) Trabalho de menores; d) Trabalhador com capacidade de trabalho reduzida, com deficiência ou doença crônica; e) Trabalhador estudante; f) Dever de informação do empregador; g) Limites à duração dos períodos normais de trabalho diário e semanal; h) Duração mínima dos períodos de repouso, incluindo a duração mínima do período anual de férias; i) Duração máxima do trabalho noturno; j) Forma de cumprimento e garantias da retribuição; 1) Capítulo sobre prevenção e reparação de acidentes de trabalho e doenças profissionais e legislação que o regulamenta; m) Transmissão de empresa ou estabelecimento; $n$ ) Direitos dos representantes eleitos dos trabalhadores.

\footnotetext{
${ }^{294}$ Segundo João Leal Amado, trata-se de gritante caso de "publicidade enganosa", visto que "o rótulo do preceito não encontra a devida correspondência no respectivo conteúdo" (AMADO, João Leal. Tratamento mais favorável e art. $4 .^{\circ},{ }^{\circ}{ }^{\circ} 1$, do código do trabalho português: o fim de um princípio? In Revista Evocati, n. 19, jul. 2007. Disponível online em http://www.evocati.com.br/evocati/artigos.wsp?tmp_codartigo=132. Acesso em: 31/08/2014).

${ }^{295}$ MartineZ, Pedro Romano et al. Código do Trabalho Anotado. $2^{\text {a }}$ Ed.. Coimbra: Almedina, 2004, p. 75.
} 
As alterações ocorridas no ordenamento português no que tange ao princípio da norma mais favorável serão analisadas em momento próprio. ${ }^{296}$ Por ora, basta reconhecer que aludido sistema jurídico talvez seja, até hoje, o que melhor consagra a atuação de referido princípio na interação das fontes trabalhistas.

$\mathrm{Na}$ Espanha, o princípio da norma mais favorável foi inicialmente reconhecido por doutrina e jurisprudência ${ }^{297}$; apenas em 1976, seria introduzido no direito positivo pelo art. 4.1 da Ley de Relaciones Laborales (LRL, Ley 16/1976) enquanto método de solução de antinomias normativas, nos seguintes termos: "En el supuesto de concurrencia de dos o más normas laborales, tanto estatales como pactadas, se aplicará aquella en la que se den las circunstancias siguientes: a) Que, apreciadas en su conjunto, resulte más favorable para el trabajador". ${ }^{298}$ Nada se falava, como se vê, a respeito da inderrogabilidade relativa das normas trabalhistas - referido critério apenas atuava como solução para conflitos entre normas. ${ }^{299}$

O preceito viria a ser repetido no art. 3.3 do atual Estatuto de los Trabajadores, segundo o qual "Los conflictos originados entre los preceptos de dos o más normas laborales, tanto estatales como pactadas, que deberán respetar en todo caso los mínimos de derecho necesario, se resolverán mediante la aplicación de lo más favorable para el trabajador apreciado en su conjunto (...)".300

Assim como em Portugal, na Espanha também existem, atualmente, inúmeras discussões acerca da amplitude do princípio do favor nas relações entre lei e negociação coletiva. Não por outra razão, a Lei $\mathrm{n}^{\circ}$ 11/1994 transferiu diversas competências normativas, antes alocadas à legislação, para o âmbito da autonomia coletiva., modificando dispositivos do Estatuto dos Trabalhadores. A matéria também será abordada com mais vagar em outro momento deste trabalho. ${ }^{301}$

\footnotetext{
${ }^{296}$ Cf. infra, capítulo 4.

${ }^{297}$ Nos acórdãos STS (6 $6^{\text {a }}$, de 30 de junho de 1966, Ar. 3636 e STS (4ª), de 29 de setembro de 1966, Ar. 3916, citados por UGUINA, Jesús R. Mercader. La silenciosa decadencia del principio de norma más favorable... Op. Cit., p. 21.

298 "Em matéria de concorrência entre duas ou mais normas laborais, tanto estatais quanto negociadas, se aplicará aquela em que se deem as circunstâncias seguintes: a) Que, apreciadas em seu conjunto, resulte mais favorável ao trabalhador" - tradução livre.

${ }^{299}$ Consoante bem exposto por UGUINA, Jesús R. Mercader. La silenciosa decadencia del principio de norma más favorable... Op. Cit., p. 21.

300 "Os conflitos originados entre os preceitos de duas ou mais normas laborais, tanto estatais quanto negociadas, que deverão respeitar, em todo caso, os mínimos de direitos necessário, se resolverão mediante a aplicação da mais favorável para o trabalhador, apreciada em seu conjunto (...)" - tradução livre.

${ }^{301}$ Cf. infra, capítulo 4.
} 
Na França, o princípio do favor é atualmente consagrado pelo art. L. 2251-1 do Código do Trabalho, in verbis:

Art. L. 2251-1: Une convention ou un accord peut comporter des stipulations plus favorables aux salariés que les dispositions légales en vigueur. Ils ne peuvent déroger aux dispositions qui revêtent un caractère d'ordre public. ${ }^{302}$

No mesmo sentido, reconhece-se a positivação do princípio no art. L. 2241-1 - o qual disciplina a relação entre instrumentos de negociação coletiva e contrato de trabalho:

Art. L. 2254-1: Lorsqu'un employeur est lié par les clauses d'une convention ou d'un accord, ces clauses s'appliquent aux contrats de travail conclus avec lui, sauf stipulations plus favorables. ${ }^{303}$

Ademais da disposição legal, o favor laboratoris é expressamente reconhecido pelos Tribunais franceses, como o Conseil constitutionnel, o Conseil d'Etat e a Cour de cassation. Nesse tom, o Conseil constitutionnel, em diversas decisões, considera que o princípio do favor deve ser elevado à categoria de princípio fundamental do Direito do Trabalho, mas não possui valor constitucional (Decisão de 13 de janeiro de 2003). ${ }^{304}$

$\mathrm{Na}$ Itália, mesmo diante da inexistência de regulamentação específica acerca dos contratos coletivos ${ }^{305}$, a legislação também consagra expressamente o princípio da norma mais favorável.

Em verdade, o princípio do favor veio consolidado em solo italiano já em 1924, quando da primeira regulamentação em matéria trabalhista: o art. 17 da Lei sobre Emprego Privado (Regio Decreto Legge 13 novembre 1924, n. 1825 - convertido na Lei n. 562 em 18 de março de 1926) previa que "Le disposizioni del presente decreto saranno osservate malgrado ogni patto in contrario, salvo il caso di particolari convenzioni od usi

\footnotetext{
302 "Uma convenção ou um acordo pode conter estipulações mais favoráveis aos empregados do que as disposições legais em vigor. Eles não podem derrogar disposições que apresentem caráter de ordem pública" - tradução livre.

303 "Uma vez que um empregador esteja vinculado às cláusulas de uma convenção ou de um acordo, essas cláusulas se aplicam aos contratos de trabalho concluídos por ele, salvo estipulações mais favoráveis" tradução livre.

${ }^{304}$ Decisão disponível em http://www.conseil-constitutionnel.fr/conseil-constitutionnel/francais/lesdecisions/acces-par-date/decisions-depuis-1959/2003/2002-465-dc/decision-n-2002-465-dc-du-13-janvier2003.854.html, acesso em 08/11/2014.

${ }^{305}$ Cf. supra, capítulo 2.
} 
più favorevoli all'impiegato e salvo il caso che il presente decreto espressamente ne consenta la deroga consensuale" (grifou-se). ${ }^{306}$

Posteriormente, a Lei $\mathrm{n}^{\mathrm{o}} 741$, de 1959 , voltou a mencionar o princípio no art. 7, nos seguintes termos:

Art. 7. I trattamenti economici e normativi minimi, contenuti nelle leggi delegate, si sostituiscono di diritto a quelli in atto, salvo le condizioni, anche di carattere aziendale, piu' favorevoli ai lavoratori.

\section{(...)}

Alle norme che stabiliscono il trattamento di cui sopra si puo' derogare, sia con accordi o contratti collettivi che con contratti individuali, soltanto a favore dei lavoratori. (grifou-se). ${ }^{307}$

Atualmente, o favor laboratoris pode ser encontrado no art. 40 do Statuto dei Lavoratori, o qual consagra a regra da impossibilidade de alteração da legislação in peius ao dispor que "ogni disposizione in contrasto con le norme contenute nella presente legge è abrogata", mas que "restano salve le condizioni dei contratti collettivi e degli accordi sindacali più favorevoli ai lavoratori". ${ }^{308}$ No mesmo sentido, há menção ao princípio no art. 1, parágrafo $2^{\circ}$, do Decreto Legislativo $n^{\circ} 151$, de 26 de março de 2001 (Testo unico delle disposizioni legislative in matéria di tutela e di sostegno della maternità e della paternità), que ressalva a aplicabilidade de disposições mais benéficas ao trabalhador, previstas em contratos coletivos, em detrimento daquelas constantes do Testo unico.

No Brasil, embora não haja previsão expressa do princípio da norma mais favorável, este pode ser extraído de alguns dispositivos legais, a saber: art. 620 da CLT (“As condições estabelecidas em Convenção quando mais favoráveis, prevalecerão sobre as estipuladas em Acordo"); art. 428, §2, da CLT (“Ao menor aprendiz, salvo condição mais favorável, será garantido o salário mínimo hora”); art. 30, II, da Lei 7.064/82 (“A empresa responsável pelo contrato de trabalho do empregado transferido

\footnotetext{
306 “As disposições do presente decreto serão observadas, a despeito de qualquer pacto em contrato, salvo o caso de particulares convenções ou usos mais favoráveis ao empregado e o caso em que o presente decreto expressamente consinta a derrogação consensual" - tradução livre.

307 "Os tratamentos econômicos e normativos mínimos, contidos nas leis delegadas, substituem-se àqueles contidos em atos, salvo as disposições, ainda que de caráter empresarial, mais favoráveis aos trabalhadores (...). As normas que estabelecem o tratamento acima podem ser derrogadas, seja por meio de acordos ou contratos coletivos, seja por meio de contratos individuais, apenas a favor do trabalhador" - tradução livre.

308 "qualquer disposição contrária às normas previstas na presente lei é revogada (...) exceto as condições dos contratos coletivos e dos acordos sindicais mais favoráveis aos trabalhadores" - tradução livre.
} 
assegurar-lhe-á, independentemente da observância da legislação do local da execução dos serviços: (...) II - a aplicação da legislação brasileira de proteção ao trabalho, naquilo que não for incompatível com o disposto nesta Lei, quando mais favorável do que a legislação territorial, no conjunto de normas e em relação a cada matéria").

De qualquer maneira, art. $8^{\circ}$ da CLT, ao tratar da integração da norma jurídica trabalhista, determina a utilização de "outros princípios e normas gerais de direito, principalmente do direito do trabalho" - e, consequentemente, do princípio da norma mais favorável - para preenchimento de lacunas da legislação consolidada.

Não por outra razão, aludido princípio é frequentemente invocado pela jurisprudência trabalhista ${ }^{309}$, bem como consagrado por diversa Súmulas e Orientações Jurisprudenciais do Tribunal Superior do Trabalho. ${ }^{310}$

\footnotetext{
${ }^{309}$ Consoante se infere dos julgados a seguir: TST - RR: 13452520125090965 , Relator: Kátia Magalhães Arruda, Data de Julgamento: 03/09/2014, 6 ${ }^{a}$ Turma, Data de Publicação: DEJT 05/09/2014; TST - AIRR: 2836020115150045 283-60.2011.5.15.0045, Relator: José Maria Quadros de Alencar, Data de Julgamento: 09/10/2013, $1^{\text {a }}$ Turma, Data de Publicação: DEJT 18/10/2013; TRT-1 - RO: 00016066820125010041 RJ , Relator: Claudia Regina Vianna Marques Barrozo, Data de Julgamento: 22/01/2014, Sexta Turma, Data de Publicação: 03/02/2014; TRT-4 - RO: 00006396920115040010 RS 0000639-69.2011.5.04.0010, Relator: BEATRIZ RENCK, Data de Julgamento: 11/12/2013, $10^{\text {a }}$ Vara do Trabalho de Porto Alegre; entre outros.

${ }^{310}$ A respeito, cf.: Súmula 288, I, TST (“A complementação dos proventos da aposentadoria é regida pelas normas em vigor na data da admissão do empregado, observando-se as alterações posteriores desde que mais favoráveis ao beneficiário do direito"); Súmula 202, TST ("Existindo, ao mesmo tempo, gratificação por tempo de serviço outorgada pelo empregador e outra da mesma natureza prevista em acordo coletivo, convenção coletiva ou sentença normativa, o empregado tem direito a receber, exclusivamente, a que lhe seja mais benéfica"); OJ-SDC-31, TST ("Não é possível a prevalência de acordo sobre legislação vigente, quando ele é menos benéfico do que a própria lei, porquanto o caráter imperativo dessa última restringe o campo de atuação da vontade das partes"); entre outras.
} 


\subsection{Relações entre lei e acordos e convenções coletivas de trabalho na atual sistemática das fontes trabalhistas}

Há grandes dificuldades no estudo das relações entre lei e negociação coletiva - especialmente tendo em vista sua intensa modificação nos últimos anos, por força da revisitação do princípio da norma mais favorável.

A seguir, debruçar-se-á, com mais vagar, sobre as discussões a respeito da revisitação do favor laboratoris. ${ }^{311}$ Por enquanto, para o escopo do presente capítulo, apenas é necessário ressaltar que, cada vez com mais frequência, doutrina, jurisprudência e a própria legislação vêm suscitando questionamentos a respeito da efetiva atuação do princípio no conflito entre normas marcadas por profunda heterogeneidade da classe trabalhadora e intensa competitividade do mercado de trabalho.

Sem adentrar tais discussões, assim, proceder-se-á a análise pura e simples das relações que, tradicionalmente, formam-se entre lei e negociação coletiva para, no próximo capítulo, descontruírem-se esses tradicionalismos diante da decadência do princípio da norma mais favorável.

Como dito, há grandes dificuldades na análise das relações entre lei e negociação coletiva. Isso porque, conforme bem salienta Luigi Mariucci, nem a lei, nem a negociação coletiva, formam um todo homogêneo: enquanto sistemas de regulamentação dos contratos individuais de trabalho, ambas contêm, dentro de si, diversos outros subsistemas, muitas vezes igualmente aplicáveis ao caso concreto. ${ }^{312}$

O autor propõe, nesse sentido, dois âmbitos de análise das relações entre lei e contratação coletiva: o primeiro, considerando-as como sistemas normativos distintos; o segundo, como fontes de direito, i.e., como instrumentos de disciplina das relações individuais de trabalho. ${ }^{313}$

\footnotetext{
${ }^{311}$ Cf. infra, capítulo 4

312 MARIUCCI, Luigi. Le fonti del Diritto del Lavoro - quindici anni dopo... Op. Cit., p. 14. O autor utiliza como exemplo o sistema de estabilidades na Itália, em que há tratamento legal totalmente díspar para estabelecimento com mais ou menos de 15 empregados - injustificada, em seu entender, já que a mesma lei faz uma distinção sem qualquer sentido. No país, ocorre também conflito entre fontes normativas coletivas, em vista do sistema de pluralidade sindical adotada.

${ }^{313}$ MARIUCCI, Luigi. Le fonti del Diritto del Lavoro - quindici anni dopo... Op. Cit., p. 90 e ss.
} 
Com efeito, já se afirmou, em outro momento deste trabalho ${ }^{314}$, que parte da doutrina entende a negociação coletiva e a lei estatal como diferentes ordenamentos jurídicos, inseridos no sistema de pluralismo que caracteriza o Direito do Trabalho. Assim, por exemplo, o posicionamento de Norberto Bobbio, o qual dedica parte de sua obra ao estudo das diversas relações possíveis entre ordenamentos estatais e não-estatais. ${ }^{315}$

Nesse caso, não se está diante de conflito entre normas, mas de verdadeiro conflito de sistemas jurídicos - o qual, por óbvio, não poderá ser resolvido pela simples aplicação de princípios de solução de antinomias, especialmente se envolver dois Estados soberanos buscando delimitar seu espaço de atuação em determinada sociedade.

Por tal razão, em sua análise, Bobbio aponta para a existência de diversos critérios de interação de normas decorrentes de ordenamentos jurídicos diversos.

Inicialmente, leciona o autor, tal como as normas internas de determinado ordenamento organizam-se conforme uma pirâmide, com diversos graus hierárquicos, é possível verificar uma "pirâmide de ordenamentos", entre os quais se instauram relações de coordenação e subordinação. $\mathrm{Na}$ coordenação, os diversos ordenamentos jurídicos atuam em pé de igualdade, em uma espécie de pacto social; já na subordinação, os ordenamentos não-estatais dependem da chancela do Estado para a legitimidade da produção normativa (e.g., o estatuto de uma associação, que necessita da ratificação estatal).

Esse é, entretanto, apenas um dos critérios que podem ser observados na interação de distintos ordenamentos jurídicos. Um segundo critério, de fato, leva em conta a extensão recíproca dos respectivos âmbitos de validade, nos seguintes termos: a) relação de exclusão total, na qual os âmbitos são delimitados de maneira que um ordenamento não se sobreponha ao outro (e.g., dois ordenamentos estatais); b) relação de inclusão total, quando um dos ordenamentos tem âmbito de validade totalmente compreendido no outro (e.g., ordenamento de um Estado-membro em relação ao ordenamento do Estado central); c) relação de exclusão parcial (ou inclusão parcial), na qual dois ordenamentos têm uma parte comum e outra não comum (e.g., ordenamento de uma associação e ordenamento

\footnotetext{
${ }^{314}$ Cf. supra, capítulo 1.

${ }^{315}$ BobBIO, Norberto. Teoria do Ordenamento Jurídico.... Op. cit., p. 165.
} 
estatal, já que há aspectos do comportamento dos associados não regidos pelo Estado, ou ordenamento do Direito e ordenamento da Moral). ${ }^{316}$

Finalmente, como terceiro critério, pode-se analisar a interação de ordenamentos sob o ponto de vista da validade que um deles atribui às normas do outro, a saber: a) relação de indiferença, quando um ordenamento considera lícito o que em outro é obrigatório (e.g., dívidas de jogo enquanto obrigações naturais); b) relação de recusa, quando um ordenamento considera proibido aquilo que em outro é obrigatório, ou obrigatório o que em outro é proibido (e.g., relação entre Estado e associação de malandros); c) relação de absorção, quando um ordenamento considera obrigatório ou proibido aquilo que no outro também é obrigatório ou proibido. ${ }^{317}$

Posicionamento similar ao de Bobbio é adotado por Georges Gurvicth, para quem o relacionamento entre o Estado e outras instituições capazes de criar leis sociais pode assumir diferentes formas. ${ }^{318}$

Inicialmente, podem-se verificar instituições de legislação social puras e com total independência do Estado. Nesse caso, na hipótese de conflito, a legislação criada pelos grupos sociais tem validade igual ou superior à do Estado (por exemplo, legislação da Igreja Católica, para Estados em que existe essa separação, e legislação econômica, para Estados pautados no liberalismo autêntico). De outra parte, podem existir instituições de legislação social puras, mas subjugadas ao Estado, ou seja, que têm autonomia jurídica, mas cedem ao Estado no caso de conflito (cujo principal exemplo é a relação familiar). Ainda, as instituições de legislação social autônoma que foram incorporadas ao Estado, que atuam diretamente com o poder estatal, na condição de entes de direito público (como, por exemplo, os sindicatos em regime corporativista), e, finalmente, as instituições de legislação social condensada na lei de Estados democráticos, quer como efetivas participantes da legislação estatal, quer de forma totalmente independente.

Sintetizando os posicionamentos acima apresentados, Luigi Mariucci afirma que, partindo do pressuposto de que lei e negociação coletiva representam ordenamentos distintos, sua interação poderá ser organizada segundo sistemas

\footnotetext{
316 “Que não se deva roubar vale tanto em Moral como em Direito; que se devam pagar as dívidas de jogo vale somente em Moral; que se deva cumprir um ato com determinadas formalidades para que seja válido vale somente em Direito" (BoBBIO, Norberto. Teoria do Ordenamento Jurídico.... Op. cit., p. 168).

${ }^{317}$ BobBio, Norberto. Teoria do Ordenamento Jurídico.... Op. cit., pp. 166-168.

${ }^{318}$ GuRVicth, Georges. The Problem of Social Law... Op. Cit.,, pp. 36-37
} 
abstencionistas ou intervencionistas: no primeiro caso, a lei incentiva a atividade negocial, enquanto, no segundo, são dispostas "mere garanzie di libertà". 319

Por óbvio, podem existir diversas matizes dentro de cada um desses sistemas (desde aquela de absoluta liberdade até a de pleno dirigismo, em que a lei determina até mesmo o conteúdo das negociações coletivas); porém, em linhas gerais, as interações determinadas por cada Estado não fogem ao esquema acima apresentado.

No entanto, conforme antes salientado, entende-se que, em realidade, não se pode falar na existência de diversos ordenamentos jurídicos no Direito do Trabalho, e sim em simples pluralidade de fontes - uma vez que, em última análise, a negociação coletiva encontra-se subjugada ao caráter centralizador da fonte estatal. Deve-se, portanto, compreender a lei estatal e o contrato coletivo como fontes integrantes do mesmo ordenamento - e, por tal razão, passíveis de adquirirem conflituosidade no interior desse sistema.

Delimitar o espaço reservado à legislação oficial e à negociação coletiva, dentro do ordenamento jurídico centralizado na figura do Estado, mostra-se tarefa sobremaneira árdua ${ }^{320}$ - especialmente porque, no Direito do Trabalho, pairam inúmeras dúvidas a respeito do conceito de "ordem pública". Segundo afirma Walküre Lopes Ribeiro da Silva, no campo das relações trabalhistas, o legislador assegura aos trabalhadores um patamar de direitos, "tendo à vista a dignidade e o valor do trabalho humano", de forma a se poder concluir que "a primeira função da ordem pública é promover a regulação social, impedindo retrocessos na sociedade". ${ }^{321}$ Assim é que, em um primeiro momento, defendeu-se que todas as normas de Direito do Trabalho seriam de ordem pública, não admitindo derrogações de qualquer espécie.

Entretanto, posteriormente, com o desenvolvimento da ideia do favor laboratoris, referido posicionamento foi revisto, passando a doutrina trabalhista a admitir "graus" de ordem pública nas normas laborais, diante de suas peculiaridades.

\footnotetext{
319 "meras garantias de liberdade" - tradução livre (MARIUCCI, Luigi. Le fonti del Diritto del Lavoro quindici anni dopo... Op. Cit., pp. 90-91).

${ }^{320}$ Conforme bem ressalta Luigi Mariucci, "il problema si pone fin dalla nascita del diritto del lavoro, data la sua duplice natura di disciplina eteronoma e di sistema di legittimazione della autonormazione collettiva, ma è destinato a mantenere la sua rilevanza, ed anzi ad accrescerla, in ragione delle più recenti tendenze normative" ("o problema se coloca desde o nascimento do Direito do Trabalho, dada sua dúplice natureza de disciplina heterônoma e de sistema de legitimação da autonormatização coletiva, mas é destinado a manter sua relevância, e também de acrescê-la, em razão das recentes tendências normativas" - tradução livre MARIUCCI, Luigi. Le fonti del Diritto del Lavoro - quindici anni dopo... Op. Cit., p. 99).

${ }^{321}$ Silva, Walküre Lopes Ribeiro da. Autonomia Privada Coletiva... Op. Cit., p. 150.
} 
A doutrina portuguesa debruçou-se com esmero sobre o tema, identificando três espécies de normas que podem ser objeto de aplicação do princípio do favor laboratoris: a) normas laborais imperativas; b) normas laborais imperativas mínimas; c) normas laborais supletivas. ${ }^{322} 323$

Inicialmente, as normas laborais imperativas (ou imperativas fixas ${ }^{324}$ ou absolutamente imperativas ${ }^{325}$ ) são aquelas que não admitem afastamento em qualquer sentido (i.e., in melius ou in peius), por qualquer outra norma (i.e., inferior ou superior), conforme regras gerais de hierarquia normativa.

Américo Plá Rodriguez refere-se a tais normas, simplesmente, como "normas de ordem pública", as quais, em seu entender, marcam não apenas um nível mínimo de proteção ao trabalhador, mas sim um nível invariável, que enseja inderrogabilidade absoluta (normalmente em razão de motivos de ordem pública). ${ }^{326}$

Tais normas demonstram que, mesmo diante do princípio da norma mais favorável, pode prevalecer lei proibitiva do Estado, quando o bem comum exigir sacrifícios momentâneos de vantagens aparentes, em benefício de determinadas categorias econômicas ou dos trabalhadores em geral. É o caso, por exemplo, de uma convenção coletiva que fixe salários acima dos níveis oficiais, em Estado pautado em políticas salariais: tal convenção mostrar-se-á ineficaz, por violar lei impositiva.

No direito positivo português, há diversos exemplos de normas absolutamente imperativas constantes do Código do Trabalho - as quais são transcritas a seguir:

\section{Artigo $236^{\circ}$, CT. Regime dos feriados}

\footnotetext{
322 Para mais informações, cf. RAmalho, Maria do Rosário Palma. Direito do Trabalho. Parte I Dogmática Geral... Op. Cit., p. 270. No mesmo sentido, cf. MourA, José Barros. A convenção colectiva entre as fonts de Direito do Trabalho. Coimbra: Almedina, 1984, pp. 64 e ss.)

${ }^{323}$ A jurisprudência portuguesa também vem reconhecendo a existência de diferentes espécies de fontes normativas, consoante se extrai de trecho de acórdão do Tribunal Constitucional: "Quanto aos regulamentos de condições mínimas, importa distinguir quatro categorias de normas do Código do Trabalho: (i) normas absolutamente imperativas, que não consentem qualquer derrogação, seja in melius, seja in pejus (exemplos: artigos $210 .^{\circ}$ e $383 .^{\circ},{ }^{\circ} .^{\circ}$, primeira parte); (ii) normas parcialmente imperativas, que consentem derrogação apenas num desses sentidos (in melius : artigo $110 .^{\circ}$; in pejus : artigos $167 .^{\circ}$, n. $^{\circ} 2$, e $369 .^{\circ},{ }^{\circ} .^{\circ}$ ); (iii) normas "dispositivas", que consentem derrogações em ambos os sentidos (exemplos: artigos 66. ${ }^{\circ}$, n. $^{\circ} 2,194 .^{\circ}$, n. $^{\circ} 1$, $314 .^{\circ}$, n. $^{\circ} 2,315^{\circ}$, n. $^{\circ} 3,316^{\circ}$, n. $^{\circ} 2$, e $383 .^{\circ}$, n. $^{\circ} 2$ ); e (iv) normas supletivas, em que a norma do Código só actua se não houver regulação por instrumento colectivo ou pelo contrato individual de trabalho (exemplos:

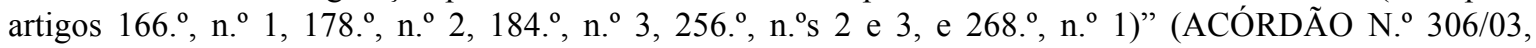
Processo n. ${ }^{\circ}$ 382/03, Relator: Cons. Mário Torres, disponível online em http://www.cnpd.pt/bin/legis/juris/TC306-03-codtrab.HTM).

${ }^{324} \mathrm{Na}$ expressão de FERnANDES, António Monteiro. Direito do trabalho... Op. Cit., p. 127.

${ }^{325} \mathrm{Na}$ expressão de AMAdO, João Leal. Contrato de Trabalho... Op. Cit., p. 42.

${ }^{326}$ RodrigueZ, Américo Plá. Princípios do Direito do Trabalho... Op. Cit., p. 52.
} 
1 - Nos dias considerados como feriado obrigatório, têm de encerrar ou suspender a laboração todas as atividades que não sejam permitidas aos domingos.

2 - $O$ instrumento de regulamentação coletiva de trabalho ou o contrato de trabalho não pode estabelecer feriados diferentes dos indicados nos artigos anteriores.

(grifou-se)

\section{Artigo $250^{\circ}$, CT. Imperatividade do regime de faltas}

As disposições relativas aos motivos justificativos de faltas e à sua duração não podem ser afastadas por instrumento de regulamentação coletiva de trabalho, salvo em relação a situação prevista na alínea g) do no 2 do artigo anterior e desde que em sentido mais favorável ao trabalhador, ou por contrato de trabalho.

(grifou-se)

\section{Artigo 339. , CT. Imperatividade do regime de cessação do contrato de trabalho}

1 - O regime estabelecido no presente capítulo não pode ser afastado por instrumento de regulamentação colectiva de trabalho ou por contrato de trabalho, salvo o disposto nos números seguintes ou em outra disposição legal. ${ }^{327} 328$

Percebe-se, de fato, que, em todos os dispositivos acima colacionados, há expressa proibição legal à negociação coletiva, a qual não poderá alterar a previsão do Código do Trabalho sequer em sentido mais favorável ao trabalhador.

Por evidente, referida espécie de norma é bastante excepcional, e normalmente reflete uma posição política ou econômica do sistema jurídico, em determinado momento. Trata-se de norma com claro intuito de proteção da coletividade, e não do trabalhador individualmente considerado, com o objetivo de melhorar a organização social de certo Estado em situações específicas.

\footnotetext{
327 As exceções mencionadas correspondem aos critérios e valores de indenização e aos prazos de procedimentos e de aviso prévio.

${ }^{328}$ Verifica-se que o dispositivo - assim como o anterior -, em realidade, não contém em si mesmo elementos reveladores de imperatividade absoluta, mas se trata de preceito anexo, que atribui natureza imperativa à generalidade das regras sobre extinção do contrato de trabalho (ou, no caso do artigo anterior, sobre faltas). Assim, diante de conflito entre cláusulas convencionais e normas legais inseridas no capítulo das faltas ou extinção do contrato, são referidos "anexos" que revelam a imperatividade da fonte estatal.
} 
Não por outra razão, salienta João Leal Amado que, no domínio da concorrência e da articulação entre as fontes trabalhistas, a imodificabilidade in melius da norma superior (i.e., sua imperatividade absoluta) e sua modificabilidade in peius por norma inferior (ou seja, sua supletividade), são excepcionais, pelo que se tornou comum a referência à natureza "imperativa-limitativa" ou "imperativa-permissiva" da norma trabalhista, "qualquer dessas expressões traduzindo a ideia de mínimo de proteção da parte mais débil da relação como traço característico e identitário das normas juslaborais". ${ }^{329}$

A doutrina portuguesa identifica, também, normas laborais imperativas mínimas (ou relativamente imperativas ${ }^{330}$ ou semi-imperativas): normas que estabelecem um mínimo de tutelas, admitindo o afastamento por fonte inferior ou pelo contrato de trabalho apenas in melius, ou seja, em sentido que mais favoreça o trabalhador. ${ }^{331}$

Trata-se, como se sabe, da mais tradicional interação de fontes laborais, orientada pelo já estudado princípio da norma mais favorável. Consoante leciona João Leal Amado, pressupõe-se que, em princípio, as normas trabalhistas possuem um caráter relativamente imperativo (normas imperativas mínimas ou normas semi-imperativas), permitindo que o regime convencional se afaste do regime legal, desde que a alteração se processe in melius e não in peius. ${ }^{332} \mathrm{O}$ favor laboratoris e a inderrogabilidade mínima, assim, tratar-se-iam das duas faces de uma mesma moeda.

No Código do Trabalho português, referida categoria de normas acaba-se mostrando a mais abrangente, podendo ser citados inúmeros exemplos, alguns colacionados a seguir: ${ }^{333}$

Art. 112. ${ }^{\circ}$ n. ${ }^{\circ}$ 5: A duração do periodo experimental pode ser reduzida por instrumento de regulamentação colectiva de trabalho ou por acordo escrito entre partes.

\footnotetext{
${ }^{329}$ AMADO, João Leal. Contrato de Trabalho... Op. Cit., pp. 43-44.

${ }^{330} \mathrm{Na}$ expressão de AMADO, João Leal. Contrato de Trabalho... Op. Cit., p. 42.

${ }^{331}$ A doutrina espanhola refere-se a este tipo de relação entre fontes laborais como expressão do denominado “princípio da norma mínima" (UGUINA, Jesús R. Mercader. La silenciosa decadencia del principio de norma más favorable... Op. Cit., p. 25).

${ }^{332}$ AMAdO, João Leal. Contrato de Trabalho... Op. Cit., p. 42.

${ }^{333}$ Outros exemplos podem ser: art. 151..: "A liberdade de celebração de contrato de trabalho a tempo parcial não pode ser excluída por instrumento de regulamentação colectiva de trabalho"; art. $184^{\circ}$ (sobre o período em que o trabalhador temporário não se encontra efetivamente prestando serviços): "Caso não exerça actividade, a compensação prevista em instrumento de regulamentação colectiva de trabalho, ou no valor de dois terços da última retribuição ou da retribuição mínima mensal garantida, consoante o que for mais favorável; art. 239. : "Da aplicação do disposto nos números anteriores não pode resultar o gozo, no mesmo ano civil, de mais de 30 dias úteis de férias, sem prejuízo do disposto em instrumento de regulamentação colectiva de trabalho".
} 
Art. 203. ${ }^{o}$, n. $^{\circ}$ 4: Os limites máximos do periodo normal de trabalho podem ser reduzidos por instrumento de regulamentação colectiva de trabalho, não podendo daí resultar diminuição da retribuição dos trabalhadores. ${ }^{334}$

Art. 235. : : Além dos feriados obrigatórios, podem ser observados a título de feriado, mediante instrumento de regulamentação colectiva de trabalho ou contrato de trabalho, a terça-feira de Carnaval e o feriado municipal da localidade.

Por fim, diante dos estudos mais recentes sobre o tema, consagrou-se o entendimento de que o Direito do Trabalho contempla, também, normas supletivas (ou dispositivas), i.e., normas que admitem seu afastamento em qualquer sentido (in melius ou in peius), seja por fonte de valor inferior, seja pelo próprio contrato de trabalho. ${ }^{335} \mathrm{Nas}$ palavras de Victor Nunes Leal, essas normas são aquelas que "deixam liberdade aos particulares de disporem de outro modo e se aplicam em caso de obscuridade ou omissão na manifestação da vontade dos interessados". 336

Com efeito, referidas normas mostram-se extremamente excepcionais já que rompem com dogmas consolidados do Direito do Trabalho, fundados no princípio da proteção. Porém, em recentes reformas da legislação (sobretudo europeia), vêm encontrando espaço, ante a necessidade de adaptação da legislação estatal às relações laborais em concreto.

Como o estudo de tais normas interessa sobremaneira à presente tese, será efetuado em momento oportuno. ${ }^{337}$ Por enquanto, apenas a título exemplificativo, citese o art. 223. ${ }^{\circ}$, n. $^{\circ}$ 2, do Código do Trabalho português, segundo o qual "o período de trabalho nocturno pode ser determinado por instrumento de regulamentação colectiva de trabalho, com observância do disposto no número anterior, considerando-se como tal, na falta daquela determinação, o compreendido entre as 22 horas de um dia e as 7 horas do dia seguinte". Porém, o art. 224. ${ }^{\circ}$ afirma que se considerará trabalhador noturno aquele que

\footnotetext{
${ }^{334} \mathrm{O}$ art. 203. ${ }^{\circ}$, n. 1, dispõe que "o período normal de trabalho não pode exceder oito horas por dia nem quarenta horas por semana". A expressão "não pode exceder" permite à negociação coletiva fixar duração normal do trabalho inferior a quarenta horas semanais ou oito horárias, mas jamais superior.

${ }^{335}$ Ressaltando-se que referida norma não precisa conferir plena liberdade de atuação para a negociação coletiva, podendo estabelecer certos limites, conforme bem exposto por MARTINEZ, Pedro Romano. Direito do Trabalho... Op. Cit., p. 267.

${ }^{336}$ LeAL, Victor Nunes. Classificação das normas jurídicas. In LeAL, Victor Nunes. Problemas de direito público e outros problemas. Brasília: Ministério da Justiça, 1997, p. 36.

${ }^{337}$ Cf. infra, capítulo 4.
} 
prestar pelo menos três horas por dia de trabalho à noite, ou outro montante definido em negociação coletiva - em outras palavras, é permitido à negociação alterar a composição do trabalho noturno, podendo até mesmo prever limite superior a três horas para que o trabalhador seja considerado "noturno".

Pedro Romano Martinez leciona que três situações distintas podem ser verificadas com relação às normas legais dispositivas ou supletivas - sobretudo entre aquelas consolidadas pelo legislador português, nas recentes reformas do Código do Trabalho. ${ }^{338}$

Inicialmente, a norma de fonte superior, sendo permissiva, pode estabelecer um limite máximo imperativo - por exemplo, quando se estatui, na legislação portuguesa $^{339}$, que o trabalho extraordinário tem por limite cento e cinquenta horas por ano. Nessa situação, fonte inferior poderia impor limite menor do que cento e cinquenta horas por ano, mas jamais superior. Entretanto, estar-se-ia diante de previsão mais favorável ao trabalhador, que não envolve qualquer inovação quanto ao princípio do favor laboratoris.

Em segunda hipótese, a norma superior pode estabelecer o limite mínimo - como ocorre, e.g., com a disciplina da retribuição mínima no ordenamento português: se estipulada, por lei, retribuição mínima de “x” euros (art. 273. ${ }^{\circ}, \mathrm{CT} / 2009$ ), a norma inferior apenas poderá estabelecer remuneração superior, mas nunca menor do que aquela. Reiterese, não há qualquer inovação em relação ao princípio da norma mais favorável.

Em terceiro lugar, poderá a norma superior estabelecer uma margem de discricionariedade entre vantagem máxima e mínima, podendo a norma inferior trabalhar dentro deste intervalo. Assim, por exemplo, o regime de intervalos (art. 213. ${ }^{\circ}, \mathrm{CT} / 2009$ ), que não pode ser inferior a uma, nem superior a duas horas.

A novidade, agora reconhecida pelo legislador português - conforme adiante se demonstrará -, reside na possibilidade de a norma inferior não apenas complementar a superior de forma mais favorável, como também de reduzir garantias e vantagens nela previstas.

\footnotetext{
${ }^{338}$ Martinez, Pedro Romano. Direito do Trabalho.... Op. Cit., p. 268.

339 Mais precisamente, no art. 228. ${ }^{\circ}, \mathrm{CT}$ : “O trabalho suplementar previsto no n. ${ }^{\circ} 1$ do artigo anterior está sujeito, por trabalhador, aos seguintes limites:

a) No caso de microempresa ou pequena empresa, cento e setenta e cinco horas por ano;

b) No caso de média ou grande empresa, cento e cinquenta horas por ano;

$(\ldots)$.
} 
A distinção entre referidas espécies de normas, entretanto, não é assim tão clara na legislação portuguesa. Com efeito, por vezes, a própria norma não evidencia sua natureza, nem existe outro preceito que a esclareça. Nessas situações, atualmente, a doutrina entende ${ }^{340}$ que deverá prevalecer o disposto no já mencionado art. 3. ${ }^{\circ}$, n. 1, do Código do Trabalho: se a norma não se revelar expressamente, absoluta ou relativamente imperativa, considerar-se-á dispositiva.

Trata-se, em outras palavras, de "presunção de supletividade", que pode ser extraída da atual dinâmica da legislação portuguesa. Assim, as normas legais presumem-se supletivas, exceto quando delas resultar o contrário (i.e., se a própria norma ou outro dispositivo evidenciar sua natureza absoluta ou relativamente imperativa) ou se a matéria regulada encontrar-se elencada entre aquelas mencionadas pelo art. $3 .^{\circ}$, n. 3 , acima indicadas (quando a norma será considerada semi-imperativa).

Portanto, baseando-se em síntese apresentada por Maria do Rosário Palma Ramalho, pode-se afirmar que na atual sistemática da legislação portuguesa, o princípio do favor laboratoris apenas se aplica em relação às normas imperativas mínimas, já que as supletivas admitem derrogação in peius e as imperativas não admitem qualquer tipo de afastamento. ${ }^{341}$

$\mathrm{Na}$ França, encontra-se posicionamento doutrinário clássico que distingue as normas em normas de ordem pública absoluta e de ordem pública relativa similarmente ao quanto propugnado pela doutrina portuguesa.

Consoante acima ressaltado, o art. 2251.1 do Code du Travail francês dispõe que "os convênios ou acordos podem comportar cláusulas mais favoráveis aos trabalhadores que a lei", fazendo a ressalva de que "não podem os convênios dispor de outra maneira que as disposições legais de ordem pública”. Nesse contexto, surgem discussões a respeito do alcance da ordem pública trabalhista, especialmente diante da previsão do art. $6^{\circ}$ do Código Civil francês, segundo a qual "on ne peut déroger, par des conventions particulières, aux lois qui intéressent l'ordre public et les bonnes mœurs". ${ }^{342}$

\footnotetext{
${ }^{340}$ Cf., por todos, Amado, João Leal. Contrato de Trabalho... Op. Cit., p. 43 e ss.

341 Ramalho, Maria do Rosário Palma. Direito do Trabalho. Parte I - Dogmática Geral... Op. Cit.,, p. 271

342 "não se podem revogar, por meio de convenções particulares, as leis que interessam à ordem pública e às boas maneiras" - tradução livre.
} 
Em breve síntese, pode-se afirmar que ordem pública trabalhista é aquela que envolve as relações entre empregador e trabalhador: corresponde ao "mínimo social” garantido pelas normas estatais e corroborado pelo princípio do favor. ${ }^{343}$

Com base em referida explicação, poder-se-ia concluir que todas as normas de Direito do Trabalho seriam consideradas de ordem pública. Entretanto, tal acepção não pode prevalecer, sob pena de se conferir ainda maior rigidez à legislação trabalhista. Por tal razão, a doutrina francesa ${ }^{344}$, em estudo mais aprofundado sobre a matéria, passou a defender a existência de duas espécies de normas dentro do conceito de "ordem pública trabalhista": normas de ordem pública absoluta e normas de ordem pública relativa (esta última também denominada, por alguns autores, “ordem pública social"). ${ }^{345}$

Inicialmente, as normas de ordem pública absoluta seriam aquelas que não admitem qualquer espécie de modificação, seja in peius ou in melius, quer pela negociação coletiva, quer pela individual. Nesse sentido, reconhece-se a existência, no direito francês, de determinadas regras fundamentais que não podem ser abordadas por cláusulas contratuais e convencionais, ainda que mais favoráveis ao trabalhador. Entre essas regras, podem-se citar aquelas que consagram a competência dos tribunais sociais, as atribuições da inspeção do trabalho, o direito de greve ${ }^{346}$, a supressão do direito ao aviso prévio e dos intervalos, as infrações laborais, etc. Segundo entendimento do Conselho de Estado Francês, trata-se de "des avantages ou garanties échappant, par leur nature, aux rapports contractuels". ${ }^{347}$

De outra parte, a ordem pública relativa - que compreende a imensa maioria das disposições do Code du Travail - permite a mudança do dispositivo legal para

\footnotetext{
${ }^{343}$ Consoante leciona Walküre Lopes Ribeiro da Silva, há grande diferença entre a ordem pública trabalhista e a ordem pública geral: enquanto as normas imperativas decorrentes da primeira são relativamente inderrogáveis (admitindo sua substituição por outra mais favorável ao trabalhador) as da segunda mostram-se absolutamente inderrogáveis, conferindo "o caráter intangível aos princípios superiores e às instituições fundamentais" (SILVA, Walküre Lopes Ribeiro da. Autonomia Privada Coletiva... Op. Cit., p. 150).

${ }^{344}$ Nesse sentido, cf., entre outros, TEYSSIÉ, Bernard. Droit du travail - Relactions collectives... Op. Cit., p. 387 e ss; VigneAU, Christophe. Le principe de faveur dans le régime du temps de travail en droit comparé... Op. Cit.; Pinson, Arnaud et SoukPRASEUTH, Delphine. Retour sur l'ordre public en droit du travail et son application par la Cour de cassation. In Boletim de Informação da Corte de Cassação, $\mathrm{n}^{\circ}$ 740, de 15 de abril de 2011, disponível online em http://www.courdecassation.fr/IMG/pdf/Bicc_740.pdf.

${ }^{345}$ Cf. Inson, Arnaud et SoukPRASEUTH, Delphine. Retour sur l'ordre public en droit du travail et son application par la Cour de cassation... Op. Cit..

${ }^{346}$ A Câmara Social da Corte de Cassação decidiu que uma convenção não pode limitar ou regulamentar o exercício do direito de greve, eis que se trata de direito constitucionalmente protegido (Decisão $\mathrm{n}^{\circ}$ 93-46.448, de 6 de junho de 1995, disponível online em http://legimobile.fr/fr/jp/j/c/civ/soc/1995/6/6/).

347 CE, sentença de 22 de março de 1973, disponível online em http://www.laloupiote.net/Cours/social/jurisprudence.php?id=189.
} 
melhorar a condição do trabalhador, em manifesta aplicação do princípio do favor laboratoris.

A partir de 1982, todavia, a classificação acima descrita passa a ser questionada, diante do surgimento dos denominados "acordos derrogatórios" (accords dérogatoires).

Com efeito, na época, sentiu-se a necessidade de fomentar a negociação coletiva e fortalecer a autonomia dos particulares, diante das demandas das empresas e dos sindicatos por uma legislação mais flexível. Assim é que foram criados os acordos derrogatórios, inicialmente por uma ordenação em matéria de duração do trabalho e, posteriormente, mediante uma série de leis promulgadas a partir de 2003.

Os acordos derrogatórios aparecem, pela primeira vez, em 1967, quando uma ordenação permitiu às partes sociais estipularem regras sobre jornada de trabalho menos favoráveis ao trabalhador. Porém, é a partir de 1982 que tal situação consolida-se: mediante a "Lei Auroux" 348 , permite-se que as convenções coletivas reduzam os direitos dos trabalhadores em matéria de duração de trabalho e licenças remuneradas.

Referida Lei fixou um patamar de 130 horas de trabalho extraordinário, que podem ser exigidas do trabalhador, sem necessidade de autorização por parte da Inspeção do Trabalho. Porém, autorizou que as partes sociais estipulem limite inferior (em manifesta aplicação da norma mais favorável) ou superior (determinando alteração in peius ao trabalhador) para referidas horas.

Mais recentemente, a denominada "Lei Fillon I", de 3 de janeiro de 2003, permitiu a negociação coletiva sobre procedimentos de dispensa do trabalhador - os quais poderão ser menos favoráveis do que os previstos em lei. Ademais, outra "Lei Fillon", de 6 de janeiro de 2004, relativa à formação profissional, consagrou diversas possibilidades de redução de direitos legais em matéria de duração do trabalho e permitiu que instrumentos coletivos de nível inferior venham a revogar instrumentos de nível superior, remodelando a hierarquia das fontes laborais coletivas.

\footnotetext{
${ }^{348}$ Em realidade, as Leis "Auroux" são um conjunto de quatro leis promulgadas no ano de 1982, na França, que alteraram profundamente a disciplina do Direito do Trabalho nesse país (Lei $\mathrm{n}^{\circ} 82-689$, de 4 de outubro de 1982, sobre liberdade dos trabalhadores perante a empresa; Lei $\mathrm{n}^{\circ}$ 82-915, de 28 de outubro de 1982, sobre representação de pessoal; Lei ${ }^{\circ}$ 82-957, de 13 de novembro de 1982, sobre negociação coletiva e conflitos laborais; e Lei ${ }^{\circ} 82-1097$, de 23 de dezembro de 1982, sobre comitês de higiene e segurança e condições de trabalho).
} 
A doutrina, assim, passa a reconhecer a existência de uma terceira espécie de ordem pública: a ordre public dérogatoire (ordem pública derrogatória), compreendida por normas que admitem qualquer tipo de derrogação, ainda que in peius, em manifesta redução da abrangência do princípio do favor. ${ }^{349}$

Desde então, tem-se entendido que os acordos derrogatórios possuem plena liberdade de adaptação das normas ao caso concreto, afastando-as, inclusive, se julgarem conveniente. Entretanto, por óbvio, para sua celebração, é necessária expressa autorização legal. Ademais, somente pela via da negociação coletiva, jamais individual, é possível efetuar referidos acordos. ${ }^{350}$

Mais uma vez, a amplitude dos acordos derrogatórios e suas principais características serão analisada em momento oportuno deste trabalho. ${ }^{351}$

Os conceitos apresentados pela doutrina portuguesa e francesa, a respeito da interação de normas coletivas e lei, também são utilizados em outros ordenamentos, especialmente europeus.

$\mathrm{Na}$ Espanha, as relações entre lei e negociação coletiva sofreram profundas transformações a partir de 1994, quando foi ampliado o âmbito de atuação da negociação. Entretanto, tais relações serão analisadas com mais vagar em outro momento deste trabalho ${ }^{352}$ - bastando, por ora, ressaltar que os critérios de ordem pública e inderrogabilidade acima apresentados também são utilizados nesse país.

De qualquer maneira, ressalte-se, desde já, que, no ordenamento espanhol, não há regramento legal específico a respeito de quais seriam as normas absolutamente inderrogáveis (ou de ordem pública absoluta), mas a doutrina e a jurisprudência tendem a apontar como exemplos as normas procedimentais do Estatuto de los Trabajadores (como sobre eleição de representantes de trabalhadores na empresa, negociação de convenções coletivas, etc.), regras sobre procedimentos judiciais e sobre capacidade e legitimidade (processual ou de negociação). De outra parte, normas sobre indenizações por extinção do contrato de trabalho, sobre garantias e prerrogativas dos

\footnotetext{
${ }^{349}$ A respeito do tema, cf. VigneAU, Christophe. Le principe de faveur dans le régime du temps de travail en droit comparé... Op. Cit., p. 256 e ss.

${ }^{350}$ Conforme ressaltado pela doutrina, também não é possível que a redução de direitos legais decorra simplesmente de um costume ou de uma iniciativa unilateral do empregador (Cf. INSON, Arnaud et SOUKPRASEUTH, Delphine. Retour sur l'ordre public en droit du travail et son application par la Cour de cassation... Op. Cit..).

${ }^{351}$ Cf. infra, capítulo 4.

${ }^{352} \mathrm{Cf}$. infra, capítulo 4.
} 
representantes de trabalhadores, entre outras, enquadrar-se-iam no critério de inderrogabilidade relativa, sendo regidas pelo princípio da norma mais favorável. ${ }^{353}$

Na Itália, Luigi Mengoni utiliza-se das expressões "leis absolutamente inderrogáveis", i.e., que não podem ser substituídas pela disciplina convencional, e "leis relativamente inderrogáveis", que podem ser de duas espécies: a) normas inderrogáveis apenas pelos contratos individuais de trabalho, permitindo-se a derrogação por contratação coletiva (situação em que prevalecerá a negociação coletiva); b) normas inderrogáveis apenas em sentido menos favorável ao trabalhador. ${ }^{354} \mathrm{~A}$ despeito da utilização de expressões diversas, entretanto, percebe-se que o conceito evidenciado pelo autor em nada difere do quanto propugnado pela doutrina portuguesa e francesa.

No Brasil, Amauri Mascaro Nascimento afirma que as relações entre lei e convenção coletiva podem ser sumarizadas em três espécies distintas: a) relação de exclusividade de atuação da lei; b) relação de concorrência, na medida em que tanto a lei quanto a convenção atuam em um campo comum, com prevalência de uma sobre a outra, a depender do caso concreto; e c) relação de complementariedade, quando a lei faz remissão à convenção, transferindo-lhe a incumbência de regular determinada matéria. ${ }^{355}$ A diferença entre a segunda e a terceira é que, na complementariedade, pressupõe-se a existência concomitante de um preceito estatal e um convencional; a supletividade, ao contrário, envolve a existência de preceitos independentes.

Interessante questionamento coloca-se com relação à possibilidade de a lei impedir alterações in melius pela norma coletiva - especificamente, em matérias salariais durante períodos de emergência e no interesse da economia. Assim, poderia a lei fixar um teto para as vantagens salariais em tais períodos?

A resposta dada por Amauri Mascaro Nascimento é afirmativa, desde que a restrição seja absolutamente necessária, transitória e determinada por interesses nacionais e imperativos do bem comum. ${ }^{356}$ Mais uma vez, consoante acima salientado, trata-se da proteção do coletivo em detrimento do interesse do trabalhador individualmente considerado.

\footnotetext{
${ }^{353}$ Sobre o tema, cf. OJEDA AviLÉS, Antonio. Compendio de derecho sindical... Op. Cit., p. 26.

${ }^{354}$ Mengoni, Luigi. Le fonti del diritto del lavoro in Italia... Op. Cit., p. 166.

${ }^{355}$ Nascimento, Amauri Mascaro. Compêndio de Direito Sindical... Op. Cit., p. 450.

${ }^{356}$ Nascimento, Amauri Mascaro. Compêndio de Direito Sindical... Op. Cit., p. 496.
} 


\section{Rediscussão do princípio da norma mais favorável: os novos contornos do Direito do Trabalho}

\subsection{Aspectos introdutórios: "crise" do Direito do Trabalho e flexibilização mediante fortalecimento da negociação coletiva}

Embora por muito tempo considerado a "autêntica alma" do Direito do Trabalho $^{357}$, o princípio da proteção vem sendo atualmente revisitado, especialmente diante das novas interações das fontes trabalhistas e do fortalecimento da contratação coletiva e da autonomia negocial dos particulares. O princípio da norma mais favorável, nesse sentido, cede espaço à ideia de adaptação da legislação às necessidades concretas das partes sociais, diante das novas realidades enfrentadas pelo Direito do Trabalho.

Consoante já ressaltado, a extensa positivação de direitos em normas estatais ensejou a consagração do Direito do Trabalho como ramo da ciência jurídica destinado à proteção do trabalhador. Porém, hoje, tal função é questionada: de acordo com Amauri Mascaro Nascimento, no atual quadro de avanços tecnológicos e imperativos do desenvolvimento econômico, o Direito do Trabalho passa a ter como meta principal a defesa do emprego, e não mais a ampliação de direitos trabalhistas, especialmente para permitir que "os interlocutores sociais possam, em cada situação concreta, compor os seus interesses diretamente, sem a interferência do Estado e pela forma que julgarem mais adequada ao respectivo momento (...)".358

Ainda no entender do mesmo autor, o Direito do Trabalho passou por fases diferentes: a da conquista e a promocional. Atualmente, encontra-se no início de fase de adaptação à nova realidade, num processo dialético de transformações do qual deve

\footnotetext{
${ }^{357}$ Em feliz expressão de Jesús R. Mercader Uguina (UGuinA, Jesús R. Mercader. La silenciosa decadencia del principio de norma más favorable... Op. Cit., p. 19).

358 Nascimento, Amauri Mascaro. Curso de Direito do Trabalho... Op. Cit., p. 70. No mesmo sentido, leciona Ives Gandra da Silva Martins Filho, para quem "não se pode atribuir ao direito do trabalho a missão de proteger o empregado (visão paternalista socializante), nem de preservar a empresa (visão conservadora flexibilizante), nem primordialmente regular o mercado (visão keynesiana intervencionista), mas, em uma síntese das posições dialeticamente opostas, promover o bem-comum (visão jusnaturalista empírica)" (Martins Filho, Ives Gandra da Silva. O bélico e o lúdico no direito e no processo. In Revista do Tribunal Superior do Trabalho, Brasília, vol. 70, 2, jul/dez de 2004, p. 29).
} 
resultar "um novo modelo que o represente, no qual a sociedade enfrenta uma série de dificuldades que atingem, mais intensamente, exatamente aqueles que não têm um emprego formal garantido". 359

A função tuitiva do Estado justificou-se em ambiente marcado por interesses homogêneos, derivados de uma classe trabalhadora composta por massa uniforme de operários sujeitos aos arbítrios do empresário. Hoje, não mais se verifica tal homogeneidade: o trabalho mostra-se cada vez mais descentralizado e multifacetado, superando a figura do "operário-padrão", ou seja, do trabalhador com contrato por prazo indeterminado e jornada completa, horário pré-estabelecido, que realiza atividade fungível e está "inserido numa comunidade organizacional, onde estabelece relações quase familiares com os colegas e superiores hierárquicos, numa perspectiva de perenidade". ${ }^{360}$

As relações laborais da atualidade são marcadas por força de trabalho cada vez mais complexa, multifuncional, "que deve ser explorada de maneira mais intensa e sofisticada" ${ }^{361}$ O mercado global e descentralizado favorece o surgimento de formas de contratação estranhas ao Direito do Trabalho clássico (como teletrabalho, terceirização, trabalho autônomo dependente, contratação por meio de pessoa jurídica ${ }^{362}$, etc.), bem como a revisitação de métodos tradicionais de prestação de serviços, como o trabalho autônomo. $^{363}$

Por óbvio, na ausência de legislação específica a disciplinar tais formas diferenciadas de contratação, sobressai o papel da negociação coletiva, sobretudo em razão

\footnotetext{
359 NASCIMENTO, Amauri Mascaro. Limites da negociação coletiva na perspectiva de projeto de flexibilização da CLT. In Revista LTr, vol. 65, nº 12, dezembro de 2011, p. 1419.

360 Silva, Maria Manuela Maia da. Flexibilidade e rigidez das leis laborais - as novas formas de contratação. In IV Congresso Nacional de Direito do Trabalho. Coimbra: Almedina, 2002, p. 98.

${ }^{361}$ ANTUNES, Ricardo. O caracol e sua concha - ensaios sobre a nova morfologia do trabalho. São Paulo: Boitempo Editorial, 2005, p. 28.

${ }^{362}$ Importante ressaltar, neste ponto, que é preciso abandonar-se a presunção de fraude envolvendo tais espécies de contratação. Muitos dos modelos acima mencionados são utilizados pelas empresas como expedientes fraudulentos para afastar os elevados ônus da legislação estatal; porém, a utilização inapropriada por determinadas empresas não pode macular o instituto como um todo - o qual se reveste de plena validade se respeitados os requisitos legais correspondentes. Para mais informações sobre os efeitos nefastos da presunção de fraude - infelizmente ainda presente nos órgãos brasileiros de fiscalização do trabalho recomenda-se a leitura de CASTELO, Jorge Pinheiro. Transformações do mercado de trabalho brasileiro Prestação de serviços intelectuais por pessoas jurídicas - Aspectos legais, econômicos e tributários Desconstruindo e construindo o paradigma de pensamento. In ANAN JR., Pedro e PEIXOTO, Marcelo Magalhães (Coord.). Prestação de Serviços Intelectuais por Pessoas Jurídicas - Aspectos Legais, Econômicos e Tributários. São Paulo: MP Editora, 2008.

${ }^{363} \mathrm{O}$ qual assume novos contornos, passando a refletir realidade também heterogênea (nas palavras da doutrina italiana, evidenciando-se "trabalho autônomo de segunda geração" (por todos, cf. PERULLI, Adalberto. Lavoro autonomo e dipendenza economica oggi In Rivista giurica del lavoro e della previdenza sociale, n. 2, anno LIV, aprile-giugno 2003).
} 
de sua grande capacidade de adaptação da lei às necessidades, in concreto, das partes sociais.

No mais, sabe-se que o excesso de rigidez da lei trabalhista - somado à exacerbada concorrência das relações mercantis do cenário econômico globalizado enseja fenômeno que se convencionou denominar "fuga do direito do trabalho", mediante o qual as empresas buscam formas alternativas de contratação para "escapar" aos excessos da legislação protetora. Referido fenômeno gera perda de efetividade prática das normas trabalhistas, em sistema que António Monteiro Fernandes bem qualifica como "ética do descumprimento". 364

Aludida rigidez do direito trabalhista estatal evidencia-se a partir das recentes transformações da produção e do mercado. O cenário transnacional de intensa competitividade leva a empresa a tornar-se multifuncional: ao mesmo tempo em que fabrica, também oferece produtos financeiros, créditos ao consumidor, ações, seguros, empréstimos $^{365}$; ademais, tem de adequar seu processo produtivo às exigências da descentralização, à subcontratação de atividades acessórias e à concorrência com mercados $^{366}$ que, notoriamente, suprimem direitos laborais em prol da maior lucratividade. $^{367}$

No intuito de driblar os elevados custos da proteção estatal, assim, muitas empresas valem-se de odiosos expedientes de adaptação da legislação oficial, mediante a instituição de ordenamentos próprios que desconsideram ou modificam as normas protetoras do Direito do Trabalho, visando estritamente ao lucro. ${ }^{368}$ Mais uma vez, aqui, destaca-se a importância da negociação coletiva: fortalecido o poder de atuação dos sindicatos, a legislação poderia ser adaptada por meio de procedimentos coletivos,

\footnotetext{
${ }^{364}$ FERNANDES, António Monteiro. Um direito do trabalho sobrevivente. In MOREIRA, António José (coord). Estudos jurídicos em homenagem ao Professor António Motta Veiga. Coimbra: Almedina, 2007, p. 60. ${ }^{365}$ NASCIMENTO, Amauri Mascaro. Compêndio de Direito Sindical... Op. Cit., p. 101.

${ }^{366}$ Os denominados "paraísos sociais" - os quais, na inspirada expressão de Bernardo da Gama Lobo Xavier, logo se transformam em "infernos laborais" (XAVIER, Bernardo da Gama Lobo. Flexibilidade e Rigidez das Leis Laborais. Novos Modelos de Prestação do Trabalho. In IV Congresso Nacional de Direito do Trabalho. Coimbra: Almedina, 2002, p. 80).

${ }^{367}$ A respeito das alterações experimentadas pelas empresas da atualidade, cf. RAMALHO, Maria do Rosário Palma. Insegurança ou diminuição do emprego? A rigidez do sistema jurídico português em matéria de cessação do contrato de trabalho e de trabalho atípico. In LTr - Legislação do Trabalho, ano 64, nº 07, julho de 2000, São Paulo, p. 1018 e ss; e XAVIER, Brito. Crise do Direito do Trabalho. In III Congresso Nacional de Direito do Trabalho - Memórias. Coimbra: Almedina, 2000, p. 249 e ss.

${ }^{368}$ Conforme leciona MAIOR, Jorge Luiz Souto. A supersubordinação - invertendo a lógica do jogo. In Revista do Tribunal Regional do Trabalho da $8^{\text {a }}$ Região, v. 41, n. 81, suplemento especial comemorativo, julho-dezembro de 2008, Belém, pp. 137-177.
} 
conforme o interesse social da classe trabalhadora, e não satisfazendo apenas às necessidades patronais.

O cenário acima apresentado fez com que se tornasse lugar-comum, em doutrina, a referência a suposta "crise" enfrentada pelo Direito do Trabalho ${ }^{369}$, evidenciada pela redução geral de empregos, criação de novos setores produtivos e formas de contratação, crescimento do setor de serviços, descentralização das atividades por meio das subcontratações, informalização do trabalho, automação, entre outros fatores.

Entretanto, entende-se que o termo "crise" é inadequado para refletir a situação vivenciada pelo Direito do Trabalho: melhor seria falar-se em "adaptação" ou, até mesmo, "evolução" desse ramo do Direito.

É nesse sentido o entender de Arion Sayão Romita, segundo o qual não se está diante de crise propriamente dita, mas sim de necessidade de adaptação da legislação trabalhista às novas realidades decorrentes das inovações tecnológicas e da globalização. O autor afirma que a utilização do termo "crise" pode indicar certa inclinação nostálgica, pois "em geral, dizemos que há crise quando nos encontramos diante de uma situação que não nos satisfaz, quando temos em mente outra situação passada ou desejada, que acreditamos ser melhor", 370

Ademais, "crise" representa falência generalizada de um modelo consolidado - e, certamente, reconhecer a falência do Direito do Trabalho, por força das alterações sofridas pelo mercado de trabalho, significa profetizar a "crise" do próprio Direito como um todo, eis que todo este é profundamente afetado pela dinâmica social, política, histórica e econômica.

Por certo, o Direito do Trabalho encontra-se diante de um dilema: compatibilizar as necessidades das empresas com a proteção do trabalhador, garantindo que a legislação tuitiva não seja óbice à atividade empresarial e, em última análise, ao

\footnotetext{
${ }^{369}$ Cf., entre outras, RAmalho, Maria do Rosário Palma. Ainda a crise do direito laboral: a erosão da relação de trabalho 'típica' e o futuro do direito do trabalho. In III Congresso Nacional de Direito do Trabalho. Coimbra: Almedina, 2000, pp. 255-266; BoRBA, Joselita Nepomuceno. Subordinação jurídica Parassubordinação - Contrato de atividade - a busca de uma nova dogmática para a relação de trabalho. In Revista de Direito do Trabalho, ano 30, no 116, outubro-dezembro de 2004, São Paulo, pp. 232-248; Romita, Arion Sayão. A flexibilização e os princípios do direito do trabalho. In RomitA, Arion Sayão. Direito do Trabalho - Temas em Aberto. São Paulo: LTr, 1988, pp. 111-120; FrEITAS, Cláudio Victor de Castro. A parassubordinação, o contrato de trabalho a projeto e o direito brasileiro - uma análise das novas relações de trabalho sob uma ótica globalizada. In LTr: Revista de Legislação do Trabalho, v. 73 , $\mathrm{n}^{\circ} 10$, outubro de 2009, São Paulo, pp. 1240-1258.

${ }^{370}$ RomitA, Arion Sayão. A crise do critério da subordinação jurídica... Op. cit., p. 42.
} 
crescimento das taxas de emprego e à melhoria das condições de trabalho. Assim, o grande desafio ao Direito do Trabalho é enfrentar uma nova questão social, decorrente "do crescimento do exército de excedentes atingidos pela redução da necessidade de trabalho humano, substituído pela maior e mais barata produtividade da tecnologia, fenômeno desintegrador que não poupou nem mesmo os países de economia mais consistente". ${ }^{371}$

Antoine Jeammaud, nesse sentido, bem ressalta que a imagem de um enriquecimento contínuo dos direitos e garantias dos trabalhadores assalariados não pode ofuscar outra função do Direito do Trabalho, qual seja, a de atender aos anseios do capitalismo e da ação patronal (mediante a proteção da força de trabalho, moderação da dominação social, pacificação e salvaguarda da concorrência). ${ }^{372}$

Tal desafio, certamente, envolve adaptação. Não a pura e simples modificação da legislação trabalhista, para suprimir direitos consagrados - como propagam os defensores da flexibilização enquanto mera desregulamentação ${ }^{373}-$, mas evolução da normativa legal para atender às necessidades concretas do mercado globalizado.

Se o Direito do Trabalho estivesse a enfrentar verdadeira crise, a solução para tais adaptações precisaria ser buscada em outro lugar: na Teoria Geral do Direito, na Economia, na Sociologia, etc. Mas não é o que ocorre, já que referida solução pode ser extraída do próprio sistema trabalhista: o fortalecimento da autonomia negocial das partes. Nesse contexto, ganha relevo a negociação coletiva, enquanto instrumento apto a flexibilizar a legislação trabalhista, sem implicar pura e simples desregulamentação de direitos.

Sabe-se que a flexibilização é tema marcado por ideologias: de um lado, daqueles que defendem sua necessária e imediata implementação, especialmente representados pelo patronato; de outro, daqueles que a abominam por completo, por entenderem que se trata de mera supressão de direitos trabalhistas consagrados. Por seu turno, os defensores da flexibilização dividem-se em duas vertentes distintas: os que pugnam por modelo puramente individualista, de retorno ao contrato de trabalho (e,

\footnotetext{
${ }^{371}$ Nascimento, Amauri Mascaro. Compêndio de Direito Sindical... Op. Cit., p. 415.

372 Jeammaud, Antoine. Droit du Travail. In Dictionnaire de la culture juridique (dir. D. Alland et S. Rials), Paris, PUF-Lamy, Coll. Quadrige, 2003.

${ }^{373}$ Interessante ressaltar que, para Amauri Mascaro Nascimento, "desregulamentação" é vocábulo que deve ser restrito ao direito coletivo do trabalho, e corresponde à "política legislativa de redução da interferência da lei nas relações coletivas de trabalho, para que se desenvolvam segundo o princípio da liberdade sindical e a ausência de leis do Estado que dificultem o exercício dessa liberdade" (NASCIMENTO, Amauri Mascaro. Compêndio de Direito Sindical... Op. Cit., p. 421). Como se vê, não há, em referida definição, a carga axiológica normalmente atribuída, pelo senso comum, ao termo "desregulamentação".
} 
consequentemente, ao liberalismo), e os que propõem sistema coletivista, em que apenas a negociação coletiva poderia instituir condições de trabalho menos favoráveis do que as previstas em lei. ${ }^{374}$

Porém, conforme bem ressalta Walküre Lopes Ribeiro da Silva, a flexibilização deve ser analisada sob dois ângulos distintos: como sinônimo de simples desregulação e precarização do contrato de trabalho ou como processo de adaptação do sistema de relações de trabalho à nova realidade econômico-social. ${ }^{375}$

Nesse sentido, de fato, a flexibilização operada pela simples redução de direitos, sem qualquer garantia ou contrapartida aos trabalhadores, e efetuada unilateralmente pelo legislador (ou mesmo pelo empregador, nos exemplos vistos acima), representa retrocesso social, contrariando a própria lógica do Direito do Trabalho ao ensejar mera desregulamentação de garantias consolidadas. A visão neoliberal de "proteção da empresa" a qualquer custo, em detrimento da proteção social, deve ser sumariamente rechaçada.

Por outro lado, contudo, deve-se conferir maior espaço à flexibilização que é fruto dos anseios dos próprios atores sociais, exteriorizados pela contratação coletiva. Se, por força do princípio da indisponibilidade de direitos, sabe-se que o trabalhador, individualmente, não pode negociar condições de trabalho diretamente com seu empregador ${ }^{376}$, é certo que, quando se encontra representado pelo sindicato, despoja-se da hipossuficiência que lhe é característica, já que o sindicato é legítimo detentor do interesse coletivo. $^{377}$

Assim, desde que conte com ampla participação dos órgãos de representação da classe trabalhadora, entende-se que a flexibilização deve ser incentivada, pois pode representar eficiente método de adaptação da rígida legislação estatal aos novos contornos da relação laboral.

Nesse sentido, não se pode simplesmente rechaçar a flexibilização, sob o argumento de que esta seria incompatível com governos de cunho social (embora, por

\footnotetext{
${ }^{374}$ SILVA, Walküre Lopes Ribeiro da. Autonomia Privada Coletiva... Op. Cit., p. 149.

${ }^{375}$ Silva, Walküre Lopes Ribeiro da. Autonomia Privada Coletiva... Op. Cit., p. 147.

${ }^{376}$ Segundo leciona Walküre Lopes Ribeiro da Silva, o modelo individualista mostra-se indefensável quando analisados dois fatores: este fecha os olhos à realidade do contrato de trabalho (em que o empregado se encontra em posição de inferioridade econômica e subordinação jurídica em face do empregador) e despreza a ascensão da autonomia privada coletiva também em outras esferas, que não a trabalhista (como no caso do direito do consumidor e do meio ambiente) (SIlva, Walküre Lopes Ribeiro da. Autonomia Privada Coletiva... Op. Cit., p. 149).

${ }^{377}$ A respeito, cf. supra, capítulo 2, item 2.3.
} 
óbvio, tal fenômeno se mostre mais presente em Estados com características neoliberais). Ao afirmar, no Brasil, que a flexibilização não é liberal, e nem social-democrata, na medida em que "aconteceu em todas essas fases da nossa história", Amauri Mascaro Nascimento bem sintetiza a questão lecionando que, longe de se tratar de questão ideológica deve a flexibilização ser analisada enquanto fato técnico jurídico integrante do Direito do Trabalho. ${ }^{378}$

Enquanto fenômeno inerente, assim, à evolução do trabalho, a flexibilização da atualidade assume novos contornos, diante da também nova realidade do mercado de trabalho: a classe operária passa a lutar por bandeiras diferentes das tradicionais, como redução da jornada e, proporcionalmente, dos salários, para manutenção dos empregos; negociação de planos de demissão incentivada, com intuito de evitar as dispensas em massa; redução de vantagens concedidas pelo empregador, diante de crises econômicas; entre outros. Segundo Amauri Mascaro Nascimento, de fato, três grandes fatores que ensejam a flexibilização das leis trabalhistas na atualidade: a crise econômica, a necessidade de redução de custos empresariais e o avanço tecnológico, que permite maior produção com menor número de empregados. ${ }^{379}$

No mesmo sentido, ressalta João Leal Amado que, no campo da concorrência e articulação das fontes trabalhistas, está-se diante de Direito do Trabalho mais "flexível", em que a contratação coletiva não é mais um instrumento vocacionado a melhorar as condições de trabalho previstas em lei, e sim "mecanismo de adequação da lei às circunstâncias e às conveniências da organização produtiva". ${ }^{380}$ Ainda, segundo Arion Sayão Romita a flexibilização da atualidade enseja o surgimento de "oposições como princípio da proteção x princípio da flexibilização ou, com maior ênfase na visão política: princípio autoritário e corporativista x princípio da democracia". ${ }^{381}$

Entretanto, por óbvio, a flexibilização das condições de trabalho pela via da negociação coletiva envolve a rediscussão de alguns dogmas e preceitos tradicionais do Direito do Trabalho - entre eles, o já estudado princípio da norma mais favorável. ${ }^{382}$ Segundo afirma Nelson Mannrich, busca-se a efetividade do Direito do Trabalho "por

\footnotetext{
${ }^{378}$ Nascimento, Amauri Mascaro. Compêndio de Direito Sindical... Op. Cit., p. 412.

${ }^{379}$ Nascimento, Amauri Mascaro. Compêndio de Direito Sindical... Op. Cit., p. 414.

${ }^{380}$ AMADO, João Leal. Contrato de Trabalho... Op. Cit., p. 45.

381 RomitA, Arion Sayão. $O$ Princípio da Proteção em Xeque. Disponível online em http://www.planalto.gov.br/ccivil_03/revista/Rev_36/artigos/Art_Arion.htm. Acesso em 17.10.11, às 16h30min.

${ }^{382}$ Cf. supra, capítulo 3.
} 
meio de uma legislação que concilie flexibilização e firmeza, mediante leis claras e simples, com mais espaço à negociação coletiva, ainda que complexa, pois a complexidade não é privilégio do Direito do Trabalho", ${ }^{383}$

${ }^{383}$ MANNRICH, Nelson. Relações entre legislado e negociado... Op. Cit.. 


\subsection{Rediscussão do princípio da norma mais favorável: aspectos doutrinários}

A necessidade de adaptação da legislação estatal aos anseios concretos do mercado e da produção, sobretudo pela via da negociação coletiva, tem levado a doutrina juslaboralista a questionar a amplitude do princípio da norma mais favorável no sistema de fontes trabalhistas.

Com efeito, no contexto de mudanças acima explicitado, não mais se justifica a centralização normativa na figura do Estado. Referida centralização, de fato, mostrou-se imprescindível diante das distorções causadas pelo sistema liberal nas relações de trabalho; porém, uma vez coibidas tais distorções e sedimentado o papel da legislação social, é necessário reconhecer a nova função do Direito do Trabalho: de pacificador das relações sociais mediante proteção dos interesses específicos dos grupos nelas envolvidos.

Nesse contexto, é preciso romper-se com o ideal secular de que a negociação coletiva só pode atuar para aumentar direitos ao trabalhador e, assim, “melhorar" sua condição de vida. Aliás, é necessário questionar o real significado do termo "melhorar" na atualidade das relações laborais: seria a positivação de novos direitos ou a adaptação daqueles já existentes às diferentes categorias de trabalhadores (altos empregados, teletrabalhadores, etc.)? Seria a manutenção de empregos a qualquer custo ou a negociação de critérios para combater crises da empresa? Seria a integração de todo trabalhador ao modelo protecionista da legislação laboral ou a aceitação de formas alternativas de prestação de serviços, com maior flexibilidade de horários e redução de custos ao trabalhador?

Os questionamentos acima apresentados têm levado a doutrina a tecer críticas (muitas vezes, bastante severas) ao princípio da norma mais favorável, bem como debruçar-se sobre sua influência no atual esquema de fontes de trabalhistas frequentemente, pugnando por sua total decadência.

O próprio Américo Plá Rodriguez, aliás, reconhece a necessidade de revisitação do princípio da norma mais favorável. Nesse sentido, afirma que, hoje, não mais se justifica a rigidez com que as normas trabalhistas regulam as relações individuais e coletivas, razão pela qual "precisamos passar de uma ordem social imposta para um 
ordenamento jurídico negociado". A tônica do direito moderno exige que a presença do Estado se transforme no sentido não de impor a ordem social, mas de propiciar aos agentes sociais a regulação autônoma de seus interesses. ${ }^{384}$

Entretanto, é na doutrina portuguesa que as críticas se elevam.

Bernardo da Gama Lobo Xavier, por exemplo, afirma que o "velho sistema das regalias em pirâmide", no qual fontes superiores estabelecem mínimos de proteção que somente podem ser ampliados por fontes subalternas, não mais se justifica, por conta de sua excessiva rigidez. De fato, tal sistema criou o modelo do "sempre mais, nunca bastante (...), uma escalada que se simplificou em escada, escada de direitos que se está transformando em torre (certamente de Babel e, porventura, apenas de papel)". 385

Pedro Romano Martinez é bastante radical quanto à importância do favor laboratoris para o Direito do Trabalho hodierno, ao afirmar que se trata de princípio que se compreende somente no estágio mais incipiente da evolução do Direito do Trabalho, revestindo-se hoje de mero interesse histórico. ${ }^{386}$

Nesse sentido, para o autor, no Direito do Trabalho atual, não há qualquer particularidade no que respeita ao conflito hierárquico de normas, valendo o "regime regra", já que a aplicação preferencial do instrumento de regulamentação coletiva ou de cláusula contratual em detrimento da lei só vale quando a norma legal expressamente o admita.

Analisando o ordenamento português, o autor leciona que o tratamento mais favorável mostrou-se importante quando da necessidade de conferir-se autonomia ao Direito do Trabalho, em relação ao Direito Civil ${ }^{387}$; porém, já em 1969, quando da elaboração da Lei do Contrato de Trabalho, assentou-se não ser necessária a manutenção de tal princípio - veja-se que o art. 13..$^{\circ}$ de referida lei determinava que o conflito hierárquico se resolvia nos termos gerais, podendo a norma inferior impor um tratamento mais favorável para o trabalhador, se não estivesse em oposição com a norma superior. Da mesma forma, atuava o Código de 2003 (e atua o Código de 2009), ao prever que a norma

\footnotetext{
${ }^{384}$ Rodriguez, Américo Plá. Princípios do Direito do Trabalho... Op. Cit., 41.

${ }^{385}$ XAVIER, Bernardo da Gama Lobo. Flexibilidade e Rigidez das Leis Laborais... Op. Cit., pp. 79-80.

${ }^{386}$ Martinez, Pedro Romano. Direito do Trabalho... Op. Cit., pp. 269-270.

${ }^{387}$ No mesmo sentido, o entendimento de Milena Silva Rouxinol, para quem "o Direito do Trabalho autonomizou-se como direito da desigualdade". (RouXINOL, Milena Silva. O principio do tratamento mais favorável nas relações entre a lei e a convenção colectiva de trabalho... Op. Cit., pp. 159-190).
} 
de fonte inferior poderia dispor em sentido mais ou menos favorável ao trabalhador, na medida em que a norma superior o permitisse. ${ }^{388}$

Para Martinez, assim, solução contrária - ou seja, admitindo-se que, em caso de conflito, prevaleceria a norma mais favorável ao trabalhador, em detrimento da regra clássica da hierarquia - "levaria ao puro subjetivismo, à incerteza das decisões e das soluções injustas". ${ }^{389}$ A aplicação da norma inferior apenas se justifica na medida em que a própria norma superior a ela reserva um campo específico de atuação - e, dentro deste campo, a norma inferior pode dispor de forma mais ou menos favorável ao trabalhador (independentemente de qualquer princípio).

Maria do Rosário Palma Ramalho, ao contrário, reconhece a importância do princípio, até hoje, no direito português. Entretanto, chama atenção para seus efeitos perversos em algumas de suas aplicações (ausência de homogeneidade dos empregados hodiernos, excesso de tutela para apenas um tipo de trabalhador - o subordinado - e necessidade de se conferir maior elasticidade à negociação coletiva) e para sua crescente inadequação em alguns aspectos, "pela maturidade entretanto atingida pelo Direito do Trabalho e pelos entes laborais". 390

Segundo a autora, o Direito do Trabalho, em suas origens, apresentou dois grandes objetivos: uma "progressividade irredutível", atingida mediante sistema jurídico mais favorável ao trabalhador, e "universalização da proteção", por meio da qual deveria haver abrangência generalizada de todos que necessitassem da tutela trabalhista. Contudo, a radicalização desses objetivos acabou levando à crise do sistema, acarretando desvios ao modelo protecionista que se pretendia implementar. ${ }^{391}$

Portanto, deve-se atentar para as alterações do quadro sociológico e jurídico que justificou a consagração deste princípio nas origens do Direito do Trabalho: as condições econômicas da categoria dos trabalhadores melhoraram globalmente, já que referida categoria afasta-se, cada vez mais, de sua homogeneidade tradicional, e os

\footnotetext{
${ }^{388}$ MARTINEZ, Pedro Romano. Direito do Trabalho. $3^{\text {a }}$ edição... Op. Cit., p. 269-270. Porém, explica o autor que "o fato de se considerar que não há qualquer particularidade em sede de conflito hierárquico de normas não retira do direito do trabalho a sua autonomia". Assim, "o direito do trabalho continua a ser um ramo do direito autónomo, não obstante a inexistência de um princípio de tratamento mais favorável". (MARTINEZ, Pedro Romano. Direito do Trabalho... Op. Cit., p. 270)

${ }^{389}$ Martinez, Pedro Romano. Direito do Trabalho... Op. Cit., p. 270

390 Ramalho, Maria do Rosário Palma. Direito do Trabalho. Parte I - Dogmática Geral... Op. Cit., p. 276.

${ }^{391}$ Ramalho, Maria do Rosário Palma. Da autonomia dogmática do Direito do Trabalho. Coimbra: Almedina, 2000, p. 17.
} 
patamares de proteção já se mostram deveras elevados (de forma que a salvaguarda de elevados níveis de tutela de empregados comuns passa a atuar contra o aumento da tutela dos restantes, como autônomos). Ademais, não parece justificado aplicar o princípio com a mesma intensidade ao nível do contrato de trabalho e ao nível da negociação coletiva, dada a maturidade das associações representativas dos trabalhadores, que atuam neste último nível, e as vantagens de se conferir maior elasticidade às convenções coletivas de trabalho. $^{392}$

Na Espanha, Jésus R. Mercader Uguina leciona que o princípio do favor, embora essencial para a determinação da autonomia do Direito do Trabalho, acabou em muito prejudicando sua afirmação enquanto disciplina puramente jurídica (especialmente por força de sua utilização desmedida pela Administração e pelos juízes). ${ }^{393}$

Por isso, desde há muito tempo, aludido princípio vem caindo em desuso na prática das relações laborais, especialmente a partir de 1994, quando a legislação foi reformada para consagrar sistema normativo que outorga prevalência à autonomia coletiva em detrimento da lei. ${ }^{394}$ Com efeito, a partir de referida alteração, o convênio coletivo deixa de apresentar função meramente complementar e exclusiva de melhora da situação do trabalhador, "para aceptar también el papel de la negociación colectiva como instrumento de adaptación a las circunstancias y exigencias de la organización productiva". 395

Miguel Rodríguez-Piñero adota posicionamento similar ao defender que, com a nova função da negociação coletiva de alterar a legislação in peius - reconhecida expressamente pelo ordenamento espanhol, como visto -, atende-se à finalidade constitucional do Direito do Trabalho de regulamentar as relações laborais. Entretanto, o autor aponta para problema envolvendo as relações entre autonomia privada coletiva e individual: se a convenção coletiva, agora, assume função de redução de garantias

\footnotetext{
392 Ramalho, Maria do Rosário Palma. Direito do Trabalho. Parte I - Dogmática Geral... Op. Cit., p. 276.

${ }^{393}$ Uguina, Jesús R. Mercader. La silenciosa decadencia del principio de norma más favorable... Op. Cit., p. 22.

395 "para aceitar também o papel da negociação coletiva como instrumento de adaptação às circunstâncias e exigências da organização produtiva" - tradução livre (UGUINA, Jesús R. Mercader. La silenciosa decadencia del principio de norma más favorable... Op. Cit., p. 22). Interessante ressaltar que, segundo o autor, a "silenciosa decadência" do princípio da norma mais favorável inicia-se já quando a doutrina afirma a prevalência da regra do conglobamento na interpretação das fontes trabalhistas - isso porque, em sendo as convenções coletivas dotadas de unidade orgânica, ainda que algumas de suas cláusulas contrarie a lei, tendem a prevalecer sobre esta, desde que, no global, seja considerada mais favorável.
} 
consolidadas, tal função não deveria, também, ser atribuída ao contrato individual, considerando-se que a autonomia coletiva não pode anular a individual ${ }^{396}$

O questionamento parece ser comum na doutrina espanhola. Também Jésus R. Mercader Uguina, com efeito, defende a mitigação do princípio do favor na regulamentação de condições de trabalho pelo próprio contrato individual, considerando-se que a aceitação voluntária e não viciada por parte do trabalhador de uma regulamentação específica, distinta da norma legal, deve-se presumir mais benéfica a ele. ${ }^{397}$

Embora de extrema relevância prática, contudo, o tema não será objeto do presente trabalho, por não apresentar vinculação direta com a tese ora defendida. De qualquer maneira, entende-se que referido posicionamento deve ser vislumbrado com cautela: por óbvio, a negociação individual de condições de trabalho poderia ser adotada para determinados trabalhadores, como altos empregados e autônomos dependentes; porém, a grande massa laboral ainda depende da atuação do sindicato para redução de direitos, em vista de sua patente condição de inferioridade em relação ao empregador. Daí a importância de conceitos como autonomia privada coletiva e interesse coletivo ${ }^{398}$ para admitir-se a flexibilização de garantias trabalhistas.

Na França, merece relevo o entendimento de Antoine Jeammaud - o qual revoluciona o quanto até aqui foi exposto ao afirmar que carece autonomia ao Direito do Trabalho. ${ }^{399}$

Com efeito, entende o autor que um ramo do direito somente adquire autonomia sistemática quando é autossuficiente. O Direito do Trabalho, ao contrário, ainda depende da aplicação de regras de outros ramos para sua completude, como o Direito Civil (conforme dispõe o próprio Code du Travail, no art. L1221-1: "le contrat de travail est soumis aux règles du droit commun" ${ }^{400}$ ), Direito Administrativo, Direito Constitucional e Direito Penal.

Ademais, a autonomia dogmática de certo ramo do Direito só é possível quando este possui princípios próprios - e a própria polissemia do termo "princípios" torna difícil a identificação de princípios gerais próprios do Direito do Trabalho, sendo melhor

\footnotetext{
396 Rodriguez-PIÑero, Miguel. Principio pro operario, condición más beneficiosa y autonomía colectiva. In Relaciones laborales: Revista crítica de teoría y práctica, No 1, 1991, pp. 38-45.

${ }^{397}$ Uguina, Jesús R. Mercader. La silenciosa decadencia del principio de norma más favorable... Op. Cit., p. 22.

${ }^{398}$ Esmiuçados em capítulo anterior (cf. supra, capítulo 2, itens 2.2 e 2.3).

${ }^{399}$ JeAmmaUd, Antoine. Droit du Travail... Op. Cit..

400 "o contrato de trabalho submete-se às regras de direito comum" - tradução livre.
} 
falar-se em meros "particularismos". ${ }^{401}$ E um desses particularismos é, justamente, a dimensão coletiva das relações laborais - a qual, conforme o atual ordenamento francês, também detém competência para alterar in peius regras da legislação estatal. ${ }^{402}$

No Brasil, entre os doutrinadores que se debruçaram sobre a decadência do princípio da norma mais favorável, certamente se destaca o brasileiro Arion Sayão Romita. Com efeito, referido autor chega, até mesmo, a afirmar que aludido princípio não existe e nem poderia ser justificado nos primórdios do Direito do Trabalho brasileiro, o qual foi pautado por um regime autoritário e corporativista. Transcreva-se, por sua importância, trecho de seu posicionamento:

“Em regime político autoritário e corporativista, não há como aceitar a tese de uma suposta proteção que o Estado dispensaria aos trabalhadores. $O$ ordenamento corporativo, longe de proclamar o primado de qualquer dos fatores da produção, cuida de preservar, privilegiar e proteger os 'superiores interesses da produção nacional', tarefa que incumbe ao Estado. A própria indole do ordenamento repele a noção de proteção dos trabalhadores, pois estes atuam no espaço político a serviço daqueles 'superiores interesses', de sorte que os destinatários da 'proteção' vêm a ser, em última análise, os detentores do poder estatal, econômico e sindical". 403

Se afastado o princípio da proteção, entretanto, como justificar a autonomia científica do Direito do Trabalho? Segundo o autor, mediante o reconhecimento de que este, enquanto disciplina jurídica, assenta-se sobre um único princípio: o da liberdade de trabalho.

Sustenta Romita, nesse sentido, que não constitui função de nenhum dos ramos do Direito proteger um dos sujeitos de dada relação social, mas sim ajustar referida relação em busca da realização do ideal de justiça. Se, para tanto, for necessário adotar providência para equilibrar os polos da relação, o Direito deve conceder à parte em posição desfavorável alguma garantia, vantagem ou benefício capaz de preencher aquele requisito. Portanto, a concessão de maiores garantias ao empregado em detrimento do empregador não se revela propriamente um princípio, e sim apenas a tentativa de consecução do ideal

\footnotetext{
${ }^{401}$ Jeammaud, Antoine. Droit du Travail... Op. Cit..

${ }^{402}$ Cf. infra, item 4.3.

${ }^{403}$ Romita, Arion Sayão. O Princípio da Proteção em Xeque... Op. Cit..
} 
de justiça, na medida em que "repugna ao ideal de justiça a proteção de um dos sujeitos de certa relação social". 404

Adotando posição menos radical, porém no mesmo sentido, já em 1989 Octavio Bueno Magano afirmava que o princípio da norma mais favorável harmonizava-se com a visão weberiana do mundo do trabalho, concebida como sociedade-máquina, totalmente burocratizada e racionalizada, na qual cada indivíduo funciona como engrenagem. Dessa visão, emerge trabalho despersonalizado, sem poder e sem vontade, que é preciso proteger de maneira sistemática e uniforme, por meio de uma legislação rígida e impostergável. Porém, o modelo de sociedade industrial vai paulatinamente cedendo lugar ao da sociedade tecnológica - e, partindo-se do avanço tecnológico, chegase à flexibilização, a qual induz à conclusão de que "na perspectiva do Direito do Trabalho flexibilizado, já não se pode dizer que o princípio da norma mais favorável seja o aspecto de maior relevo desta disciplina”.

O conceito da norma mais favorável, portanto, já não pode ser considerado como princípio formador do Direito do Trabalho, pois deve dar lugar à noção do interesse predominante do trabalhador, reconhecido pelo grupo profissional a que pertence, de modo que suas condições de trabalho possam ser modificadas in melius ou in peius, conforme as circunstâncias. ${ }^{405}$

Nelson Mannrich - analisando a experiência portuguesa de prevalência do negociado sobre o legislado - afirma que a revisitação do princípio da norma mais favorável deve partir de alguns pressupostos. A começar, deve-se repensar o papel da legislação trabalhista em confronto com o poder normativo dos grupos: aquela não pode ser mera coadjuvante, devendo-se reservar "um espaço vital onde encerramos aqueles valores que não admitimos sejam sacrificados em nome do progresso ou dos interesses da produção" (ou seja, determinar quais direitos podem ser reduzidos pela negociação coletiva e quais somente podem ser ampliados). De outra parte, ao contrato de trabalho, "mais do que preencher lacunas ao estabelecer cláusulas relativas a função, local de trabalho, salário e turno", cabe o papel de impor limites ao poder do empregador em face do trabalhador. Por fim, a negociação coletiva não pode ser interpretada como mero substituto da lei ditada pelo Estado, mas verdadeiro "parceiro do empregador, maior

\footnotetext{
${ }^{404}$ ROMITA, Arion Sayão. O Princípio da Proteção em Xeque... Op. Cit..

${ }^{405}$ Magano, Octavio Bueno. A determinação da norma mais favorável In Anais do X Congresso Iberoamericano de Direito do Trabalho e da Seguridade Social, Montevideo, Abril de 1989, Tomo I.
} 
interessado em derrogar a lei que não lhe interessa", sempre aliando-se ao Estado na histórica missão de impedir o arbítrio patronal e a ditadura contratual, para garantir efetivo respeito à dignidade e à cidadania do trabalhador. ${ }^{406}$

Ainda, destaca-se na matéria o posicionamento de Amauri Mascaro Nascimento, para quem a contratação coletiva deixou de ser um mecanismo unilateral de introdução de melhorias em nível coletivo para os trabalhadores, passando a ser "um instrumento bilateral cujo conteúdo é também gerencial e administrativo, concessivo ou recessivo, perante um sindicalismo mais maleável", conhecedor das dificuldades empresariais e da necessidade de ação conjunta visando ao interesse comum da defesa dos empregos. ${ }^{407}$

Independentemente do posicionamento adotado acerca da revisitação do princípio da norma mais favorável, a ampliação do papel da negociação coletiva em diversos ordenamentos é um fato, especialmente nas últimas duas décadas. Por tal razão, a partir de agora, passar-se-á à análise de referidas alterações legislativas, primeiramente em países europeus, para, após, adentrar-se a experiência brasileira no tema da prevalência do negociado sobre o legislado.

${ }^{406}$ MANNRICH, Nelson. Relações entre legislado e negociado... Op. Cit..

${ }^{407}$ Nascimento, Amauri Mascaro. Compêndio de Direito Sindical... Op. Cit., p. 489. 


\subsection{Rediscussão do princípio da norma mais favorável: alterações legislativas}

Alguns ordenamentos europeus - em manifesta revisitação do princípio da norma mais favorável - têm alterado seu corpo legal para admitir a possibilidade de modificação in peius da legislação estatal pela negociação coletiva, reconhecendo, em diversas ocasiões, a prevalência do negociado sobre o legislado.

Referidas alterações, em realidade, não são fenômeno recente: em 1962, Armand Kayser já apontava para tendência, entre os países da Comunidade Europeia de Carvão e Aço (ou seja, Alemanha, França, Itália, Luxemburgo, Bélgica e Holanda) de permitir-se à negociação coletiva a fixação de direitos inferiores ao mínimo legal, com base em duas considerações: a) que o sistema de tratativas coletivas restabelece o equilíbrio econômico entre as partes; e b) que os sindicatos estão aptos a valorar os interesses e necessidades econômicas dos trabalhadores. ${ }^{408}$

E, conforme bem salienta Amauri Mascaro Nascimento, em referidos Estados europeus, o choque entre negociado e legislado não tem o mesmo impacto do que no Brasil, "porque a legislação trabalhista, nesses países, ocupa um espaço bem menor, com que a esfera natural dos convênios coletivos é maior". ${ }^{409}$ Ainda assim, percebe-se grande preocupação com a regulamentação das relações entre lei e negociação coletiva, delimitando-se até onde pode a última atuar em detrimento da primeira.

\subsubsection{A experiência portuguesa}

Certamente, o Estado que mais se destaca na superação do modelo estritamente legislado é Portugal.

Com efeito, nesse país - conforme antes salientado ${ }^{410}$-, a Lei do Contrato de Trabalho - LCT, de 1967, estabelecia, no art. 13. ${ }^{\circ}$, n. ${ }^{\circ} 1$ que "as fontes de direito superiores prevalecem sempre sobre as fontes inferiores, salvo na parte em que

\footnotetext{
${ }^{408}$ KAYSER, Armand. Le fonti del diritto del lavoro nel diritto dei paesi membri della comunità - Rapporto ricapitolativo In Boldt, Gerhard; Durand, Paul; Horion, Paul; KaYser, Armand; Mengoni, Luigi; MolenaAr, A. N. Le Fonti Del Diritto Del Lavoro. Comunità Europea del Carbone e dell'acciaio - Alta autorità, Luxemburgo, 1962, p. 30.

${ }^{409}$ NASCIMENTO, Amauri Mascaro. Compêndio de Direito Sindical... Op. Cit., p. 420.

${ }^{410}$ Cf. supra, capítulo 3, item 3.1 .
} 
estas, sem oposição daquelas, estabelecem tratamento mais favorável para o trabalhador”. O dispositivo era complementado pelo art. 6. ${ }^{\circ}$ da Lei dos Instrumentos de Regulamentação Colectiva - LRCT (Decreto-Lei n. ${ }^{o}$ 519-C1/79), segundo o qual as convenções coletivas não poderiam "contrariar as normas legais imperativas" ou "incluir qualquer disposição que importe para os trabalhadores tratamento menos favorável do que o estabelecido por lei”.

O favor laboratoris, aliás, mostrava-se recorrente em toda a LRCT: além do já mencionado art. $13 .^{\circ}$, o art. $15^{\circ}$ do mesmo diploma legal previa que direitos adquiridos durante a vigência de determinada convenção coletiva só poderiam ser reduzidos por novo instrumento de regulamentação coletiva, e desde que este fosse globalmente mais favorável do que o anterior; o art. $14 .^{\circ}$, por seu turno, dispunha que o contrato de trabalho somente poderia afastar normas legais e cláusulas de instrumento de regulamentação coletiva para estabelecer regime mais favorável ao trabalhador; e o art. 14. ${ }^{\circ}$, n. $^{\mathrm{o}} 2 \mathrm{~b}$ indicava o favor laboratoris como critério de solução de conflitos entre duas convenções coletivas de trabalho.

Verificava-se nítida manifestação do princípio da norma mais favorável em referidas previsões - o que leva João Leal Amado a afirmar que a imodificabilidade in melius da norma superior (ou seja, a imperatividade absoluta desta), bem como sua modificabilidade in peius por norma inferior (ou seja, a supletividade daquela), eram excepcionais, sendo comum aludir-se a uma "singular imperatividade" das normas juslaborais, bem como a sua natureza "imperativa-limitativa" ou "imperativa-permissiva", qualquer dessas expressões "traduzindo a ideia de mínimo de protecção da parte mais débil da relação como traço característico e identitário das normas juslaborais". 411

A partir de 2003, entretanto, o sistema de privilégio da normativa mais favorável começa a sofrer profundas alterações.

Nesse sentido, veja-se a redação do art. $4^{\mathrm{o}}$, n. $^{\mathrm{o}}$ 1, do Código do Trabalho de 2003 - com especial destaque ao quanto previsto no n. $^{\circ} 1$ de referido dispositivo:

\section{Princípio do tratamento mais favorável}

1 - As normas deste Código podem, sem prejuizo do disposto no número seguinte, ser afastadas por instrumento de regulamentação colectiva de trabalho, salvo quando delas resultar o contrário.

411 Amado, João Leal. A Reforma do Código do Trabalho. CEJ-IGT. Coimbra Editora: Coimbra, 2004, p. 115. 
2 - As normas deste Código não podem ser afastadas por regulamento de condições mínimas.

3 - As normas deste Código só podem ser afastadas por contrato de trabalho quando este estabeleça condições mais favoráveis para o trabalhador e se delas não resultar o contrário.

(grifou-se)

E, corroborando tal entendimento, o art. 533. ${ }^{\circ}$ do mesmo Código sucessor do supramencionado art. $6^{\circ}$ da Lei dos Instrumentos de Regulamentação Colectiva -, ao disciplinar os limites da negociação coletiva, passa a prever que:

\section{Limites}

1 - Os instrumentos de regulamentação colectiva de trabalho não podem:

a) Contrariar as normas legais imperativas;

b) Estabelecer regulamentação das actividades económicas, nomeadamente no tocante aos periodos de funcionamento das empresas, ao regime fiscal e à formação dos preços;

c) Conferir eficácia retroactiva a qualquer das suas cláusulas, salvo tratando-se de cláusulas de natureza pecuniária de instrumento de regulamentação colectiva de trabalho negocial.

2 - Os instrumentos de regulamentação colectiva de trabalho podem instituir regimes complementares contratuais que atribuam prestações complementares do subsistema previdencial na parte não coberta por este, nos termos da lei.

(grifou-se)

Em outras palavras: embora referido dispositivo continue a prescrever que as convenções coletivas não podem contrariar normas legais imperativas, deixa de acrescentar que aquelas também não podem incluir qualquer disposição com tratamento menos favorável para o trabalhador em relação ao estabelecido por lei. ${ }^{412}$

\footnotetext{
${ }^{412}$ Com relação às demais menções ao princípio contidas na anterior LCT, o novo Código passa a estabelecer que: a) é possível o afastamento da negociação coletiva pelo contrato de trabalho, desde que a norma em questão seja não-imperativa e de forma mais favorável (art. 531. ${ }^{\circ}$ ); não foi mantida a previsão do favor laboratoris como critério de resolução da concorrência entre duas convenções coletivas (prevalecendo a regra da especialidade ou a escolha pelos trabalhadores do instrumento aplicável - art. 536. ${ }^{\circ}$ ); não foram mantidas as referências ao princípio como critério de resolução do conflito entre normas no tempo, tampouco a referência deste princípio enquanto critério condicionador da relação entre lei e contrato de trabalho.
} 
Assim, a despeito de o art. $4 .^{\circ}$ vir previsto sob a epígrafe "Princípio do tratamento mais favorável" ${ }^{\prime 13}$, consagra severa mitigação a tal princípio, ao permitir sejam normas do Código do Trabalho afastadas pela negociação coletiva, ainda que in peius, exceto quando o legislador tenha proibido expressamente tal afastamento. Como salienta Pedro Romano Martinez, essa proibição pode tanto ser absoluta - caso das normas imperativas de conteúdo fixo, que, por conterem valores de ordem pública, não admitem qualquer derrogação, in melius ou in peius - quanto relativa - como, e.g., nas normas parcialmente imperativas, que apenas admitem derrogação in melius. ${ }^{414}$

No entender de João Leal Amado, referido artigo explicita que, em princípio, o Direito do Trabalho legislado possui caráter facultativo ou supletivo em relação à contratação coletiva. Dessa forma, as normas legais seriam meramente “convênio-dispositivas" ou "coletivo-dispositivas", na medida em que livremente afastáveis por convenção coletiva, ainda que in peius (mas jamais pelo contrato individual de trabalho, saliente-se).

No entender do autor, está-se diante de verdadeira revolução na filosofia básica inspiradora do Direito do Trabalho, já que, "de um direito com uma vocação tutelar (...), imbuído do princípio da norma social mínima, transitámos para uma espécie de direito neutro, em que o Estado recua e abandona a definição das condições de trabalho à autonomia colectiva" ${ }^{415}$ No mesmo sentido, Maria do Rosário Palma Ramalho ressalta que a novel redação consagrou a supletividade normativa como regra, permitindo-se aos instrumentos coletivos estabelecer regimes menos favoráveis do que a lei, dentro de certos limites. $^{416}$

Bernardo da Gama Lobo Xavier é um dos grandes defensores das alterações operadas pelo Código do Trabalho. Com efeito, mesmo antes de referidas alterações, pugnava pela necessidade de conferir-se maior autonomia à negociação coletiva, elencando inúmeras vantagens no sistema de valorização da negociação coletiva, a saber: a) evitar o frenesi normativo, que não dava espaço à autonomia coletiva; b) reforçar a autonomia coletiva e as capacidades dos parceiros sociais de encontrar soluções

\footnotetext{
${ }^{413}$ Epígrafe que, no entender de Jorge Leite, aparenta certa ironia do legislador reformista (LEITE, Jorge. Código do Trabalho - algumas questões de inconstitucionalidade.... Op. Cit, p. 271).

${ }^{414}$ Martinez, Pedro Romano et al. Código do Trabalho Anotado. $2^{\mathrm{a}}$ Ed.. Coimbra: Almedina, 2004, p. 75.

415 Amado, João Leal. Contrato de Trabalho... Op. Cit., pp. 44-45.

${ }^{416}$ Ramalho, Maria do Rosário Palma. Direito do Trabalho. Parte I - Dogmática Geral... Op. Cit., p. 277.
} 
negociadas; c) promover, melhorar e adaptar o regime legal a situações, setores e conjunturas; d) estabelecer um sistema de padronização ao nível adequado. ${ }^{417}$

Importante ressaltar, de toda forma, que a possibilidade de afastamento da normativa legal in peius, no sistema do CT/2003, era restrita à negociação coletiva: quanto ao contrato individual de trabalho, o art. 4. ${ }^{\circ}$, n. ${ }^{\circ} 3$, ditava que "as normas deste Código só podem ser afastadas por contrato de trabalho quando este estabeleça condições mais favoráveis para o trabalhador e se delas não resultar o contrário". Em outras palavras: na classificação proposta por João Leal Amado, as normas trabalhistas mostravam característica supletiva em relação à negociação coletiva, mas relativamente imperativas em face do contrato de trabalho. ${ }^{418}$

Tal diferenciação, aliás, leva Maria do Rosário Palma Ramalho a afirmar que, embora se observe redução do valor do princípio da proteção no Código de 2003, este "manteve seu relevo na maioria das operações envolvidas na aplicação das fontes laborais e na sua relação com o contrato de trabalho". 419420

A alteração operada pelo Código do Trabalho de 2003, por óbvio, não restou incólume às críticas. A mais severa delas, certamente, é a que questiona a compatibilização do art. $4 .^{\circ}$, n. $^{\circ} 1$ com a Constituição Portuguesa - em especial, com o art. $59 .^{\circ},{ }^{\circ}{ }^{2}$, segundo o qual:

Art. 59. ${ }^{\circ},{ }^{\circ}{ }^{2}$. Incumbe ao Estado assegurar as condições de trabalho, retribuição e repouso a que os trabalhadores têm direito, nomeadamente:

\footnotetext{
${ }^{417}$ XAVIER, Bernardo da Gama Lobo. Convenções colectivas, usos e o sistema de fontes de direito do trabalho (art. ${ }^{\circ} \mathbf{1}^{\mathbf{0}}$ e $4^{\mathbf{0}}$ do CT). In VII Congresso Nacional de Direito do Trabalho - memórias. Coimbra: Almedina, 2004, pp. 237-241.

418 Porém, veja-se da redação de referido artigo que ele próprio contempla exceções (“...e se delas não resultar o contrário"), i.e., normas absolutamente imperativas ou supletivas - o que deveria ser analisado caso a caso, conforme a redação da própria norma. Como exemplo de referidas exceções, João Leal Amado aponta para o art. $254^{\circ}$ do $\mathrm{CT} / 2003$, segundo o qual "O trabalhador tem direito a subsídio de Natal de valor igual a um mês de retribuição, que deve ser pago até 15 de Dezembro de cada ano". Com base na disciplina do CT/2003, o valor do subsidio, por certo, não poderia ser reduzido por cláusula contratual, mas poderia sê-lo mediante cláusula convencional (AMADO, João Leal. Contrato de Trabalho... Op. Cit., pp. 44-45).

419 Ramalho, Maria do Rosário Palma. Direito do Trabalho. Parte I - Dogmática Geral... Op. Cit., p. 278. A autora afirma, ainda, que as alterações introduzidas pelo CT/2003 atingiram o princípio nas áreas em que sua imposição, nos rígidos moldes anteriormente previstos, tinha apresentado efeitos mais perversos especialmente na relação entre os instrumentos de regulamentação coletiva e as normas legais, reconhecendo-se a maioridade das associações sindicais na negociação coletiva.

${ }^{420}$ Em sentido diametralmente oposto, afirma Pedro Romano Martinez que tanto a norma do art. $4 .^{\circ}$, n. $^{\circ} 3$ (que alude ao tratamento mais favorável nas relações entre contrato de trabalho e lei), quanto a norma do art. 531..$^{\circ}$ (que trata da relação entre contrato de trabalho e negociação coletiva) nada trazem de novo relativamente aos pressupostos em que assenta o conflito de normas, já que, em seu entender, o contrato de trabalho não pode ser considerado verdadeira fonte normativa (MARTINEZ, Pedro Romano. Direito do Trabalho...Op. Cit., p. 263).
} 
a) O estabelecimento e a actualização do salário mínimo nacional, tendo em conta, entre outros factores, as necessidades dos trabalhadores, o aumento do custo de vida, o nivel de desenvolvimento das forças produtivas, as exigências da estabilidade económica e financeira e a acumulação para o desenvolvimento;

b) A fixação, a nível nacional, dos limites da duração do trabalho;

c) A especial proteç̧ão do trabalho das mulheres durante a gravidez e após o parto, bem como do trabalho dos menores, dos diminuidos e dos que desempenhem actividades particularmente violentas ou em condições insalubres, tóxicas ou perigosas;

d) $O$ desenvolvimento sistemático de uma rede de centros de repouso e de férias, em cooperação com organizações sociais;

e) A protecção das condições de trabalho e a garantia dos beneficios sociais dos trabalhadores emigrantes;

f) A protecção das condições de trabalho dos trabalhadores estudantes.

Como se depreende do dispositivo acima colacionado, a Constituição Portuguesa parece impor ao legislador a obrigação de estabelecer um mínimo social de proteção aos trabalhadores. Em outras palavras, segundo João Leal Amado, “ainda que se trate de um princípio não escrito, o princípio da norma social mínima parece encontrar-se implicitamente plasmado no corpo normativo constitucional". 421

De outra parte, o art. 56..$^{\circ}$ n..$^{\mathrm{o}} 3$, da Constituição Portuguesa, assegura às associações sindicais o exercício do "direito de contratação colectiva, o qual é garantido nos termos da lei", restando asseverado, no n. ${ }^{\circ}$, que "a lei estabelece as regras respeitantes à legitimidade para a celebração das convenções colectivas de trabalho, bem como à eficácia das respectivas normas". ${ }^{422}$

João Leal Amado, confrontando ambos os dispositivos, salienta que deve haver um mínimo legal intangível, a assegurar que os direitos trabalhistas legalmente consagrados não funcionem como simples moeda de troca em sede de negociação coletiva.

${ }^{421}$ AMAdO, João Leal. Contrato de Trabalho... Op. Cit., p. 48.

${ }^{422}$ Em comentário a referido dispositivo, Joaquim José Gomes Canotilho e Vital Moreira asseveram que o direito de contratação coletiva envolve o "direito à autonomia contratual colectiva, não podendo deixar de haver um espaço aberto à disciplina contratual colectiva, o qual não pode ser aniquilado por via normativoestadual". Assim, "a lei não pode deixar de delimitá-lo de modo a garantir-lhe um mínimo de eficácia constitucionalmente relevante (...), havendo sempre de garantir uma reserva de convenção colectiva, ou seja, um espaço não vedado à contratação colectiva". Ou seja, a lei não pode "aniquilar o direito de contratação colectiva ocupando-se ela mesma da regulamentação das relações de trabalho em termos inderrogáveis por convenção colectiva" (CANOTILHO, Joaquim José Gomes et Moreira, Vital. Constituição da República Portuguesa Anotada. 3. a edição. Coimbra: Coimbra Editora, 1993, pp. 306-307). 
Dessa maneira, o jurista critica severamente o art. $4^{\circ}$, do CT/2003, afirmando que o Estado-legislador, mediante tal previsão, "retrai-se e parece mesmo demitir-se das suas responsabilidades (...), numa autêntica demissão parlamentar/governamental". ${ }^{423}$

Ao desferir suas críticas, o autor faz uma ressalva: não se mostra contrário à inserção de certa flexibilização ao Direito do Trabalho, para se admitir a existência de normas legais de caráter "convênio-supletivo"; porém, critica o pressuposto criado por referido artigo no sentido de que todas as normas legais possam ser afastadas pela negociação coletiva, inclusive in peius. Em seu entender, ocorre verdadeira quebra da espinha dorsal do Direito do Trabalho, em manifesta violação ao dever constitucional de o Estado assegurar as condições de trabalho, retribuição e repouso.

No mesmo sentido, manifesta-se João José Abrantes, para quem o direito à contratação coletiva só preenche sua função social e econômica se forem mantidos princípios como o do tratamento mais favorável do trabalhador, "que são princípios fundamentais de uma ordem pública social (...)”. Assim, o art. $4 .^{\circ}$, n. ${ }^{\circ} 1$, em seu entender, é inconstitucional, pois viola o direito fundamental dos trabalhadores portugueses de ver assegurada sua igualdade substancial em relação ao empregador. ${ }^{424}$

Também Jorge Leite - reconhecendo caráter constitucional ao princípio da norma mais favorável, especialmente por força das garantias mínimas estatuídas pelo mencionado art. 59 - posiciona-se pela inconstitucionalidade do art. $4 .^{\circ},{ }^{\circ}{ }^{\circ} 1$. Em crítica, aliás, bastante fundamentada, apresenta o seguinte óbice à aceitação da negociação in peius em relação à legislação protetora:

"Mal se compreenderia, aliás, como poderá o Estado desempenhar, por exemplo, a incumbência constitucional de assegurar as condições de trabalho $\left(n .^{\circ} 2\right.$ do art. $\left.59 .^{\circ}\right)$ - de todas e não apenas das que enumera, a título exemplificativo, nas alíneas do número do citado artigo - se a lei que as estabelece permitir, ao mesmo tempo, o seu afastamento por convenção colectiva”. ${ }^{425}$

\footnotetext{
${ }^{423}$ AMAdO, João Leal. Contrato de Trabalho... Op. Cit., p. 48.

424 Abrantes, João José. O Código do Trabalho e a Constituição. In Questões Laborais: Código do Trabalho - questões de (in)constitucionalidade. Ano X, Coimbra Editora, Coimbra, 2003, pp. 150-153.

${ }^{425}$ LeITE, Jorge. Código do Trabalho - algumas questões de inconstitucionalidade.... Op. Cit, p. 274.
} 
Por tal razão, o autor afirma que a possibilidade de afastamento de standards sociais por convenção coletiva, em sentido menos favorável ao trabalhador, pode ser aceita como exceção, mas jamais como princípio. ${ }^{426}$

Ademais das críticas envolvendo a suposta inconstitucionalidade do art. 4. ${ }^{\circ}$, n. ${ }^{\circ}$ 1, do CT/2003, outras são desferidas pela doutrina. Assim, por exemplo, João Leal Amado ressalta o fato de que, na verdade, o reconhecimento da autonomia coletiva não se processou contra a heteronomia estatal, mas sim contra o poder decisório unilateral do empregador. Ou seja, a autonomia coletiva veio somar-se - e não contrapor-se - à heteronomia estadual, "aliando-se a esta, em ordem a impedir o arbítrio patronal e a 'ditadura contratual' de outro modo imposta pelo contraente mais poderoso". ${ }^{427}$ Agora, porém, a contratação coletiva parece atuar em sentido contrário: combatendo diretamente a lei, age em favor de referida "ditadura", permitindo a adaptação da legislação consolidada em favor dos interesses empresariais. E isso tudo em tempos em que se fala de manifesta crise estrutural do sindicalismo e diante de um Código que não estabelece quaisquer exigências de representatividade mínima para que um sindicato possa celebrar uma convenção coletiva de trabalho. ${ }^{428}$

As críticas desferidas pela doutrina portuguesa, todavia, não impediram que a postura adotada pelo art. $4 .^{\circ}$ do CT/2003 fosse, posteriormente, repetida na reforma do Código do Trabalho, ocorrida em 2009. Veja-se, a respeito, a redação do art. $3 .^{\circ}$ do novo Código:

Artigo 3. ${ }^{\circ}$. Relações entre fontes de regulação

1 - As normas legais reguladoras de contrato de trabalho podem ser afastadas por instrumento de regulamentação colectiva de trabalho, salvo quando delas resultar o contrário.

2 - As normas legais reguladoras de contrato de trabalho não podem ser afastadas por portaria de condições de trabalho.

3 - As normas legais reguladoras de contrato de trabalho só podem ser afastadas por instrumento de regulamentação colectiva de trabalho que, sem oposição daquelas normas, disponha em sentido mais favorável aos trabalhadores quando respeitem às seguintes matérias:

a) Direitos de personalidade, igualdade e não discriminação;

b) Protecção na parentalidade;

c) Trabalho de menores;

\footnotetext{
${ }^{426}$ LeITE, Jorge. Código do Trabalho - algumas questões de inconstitucionalidade.... Op. Cit, p. 274.

${ }^{427}$ AMADO, João Leal. Contrato de Trabalho... Op. Cit., p. 50.

${ }^{428}$ AMADO, João Leal. Contrato de Trabalho... Op. Cit., p. 50.
} 
d) Trabalhador com capacidade de trabalho reduzida, com deficiência ou doença crónica;

e) Trabalhador-estudante;

f) Dever de informação do empregador;

g) Limites à duração dos períodos normais de trabalho diário e semanal;

h) Duração mínima dos períodos de repouso, incluindo a duração mínima do periodo anual de férias;

i) Duração máxima do trabalho dos trabalhadores nocturnos;

j) Forma de cumprimento e garantias da retribuição;

l) Capítulo sobre prevenção e reparação de acidentes de trabalho e doenças profissionais e legislação que o regulamenta;

m) Transmissão de empresa ou estabelecimento;

n) Direitos dos representantes eleitos dos trabalhadores.

4 - As normas legais reguladoras de contrato de trabalho só podem ser afastadas por contrato individual que estabeleça condições mais favoráveis para o trabalhador, se delas não resultar o contrário.

5 - Sempre que uma norma legal reguladora de contrato de trabalho determine que a mesma pode ser afastada por instrumento de regulamentação colectiva de trabalho entende-se que o não pode ser por contrato de trabalho.

Percebe-se que o citado dispositivo - abandonando a criticada epígrafe "Princípio do tratamento mais favorável" para, agora, referir-se às "Relações entre fontes de regulação" - mantém a regra geral da possibilidade de afastamento da legislação estatal pela negociação coletiva, mas, logo em sequência, contempla extenso rol de matérias que apenas admitem derrogação in melius pelas convenções coletivas de trabalho.

Dessa forma, também no CT/2009 prevaleceu o caráter "convêniodispositivo" das normas trabalhistas - porém, agora, são expressamente elencadas pelo legislador regras de caráter relativamente imperativo no n. ${ }^{\circ}$ 3. E mais: percebe-se que referidas regras podem, elas mesmas, estabelecer sua natureza absolutamente imperativa, conforme se extrai da expressão "sem oposição daquelas normas", contida no dispositivo. Ainda, ademais das normas relativamente imperativas do n. ${ }^{\circ} 3$, outras poderão prever sua imperatividade, conforme autorizado pelo próprio $n .^{\circ} 1$ do art. $3 .^{\circ}$ ao afirmar que "as normas legais reguladoras de contrato de trabalho podem ser afastadas por instrumento de regulamentação colectiva de trabalho, salvo quando delas resultar o contrário". ${ }^{429}$

\footnotetext{
${ }^{429}$ Como exemplos, podem-se citar os já mencionados artigos $112 .^{\circ}, n^{\circ} 5$, segundo o qual "a duração do período experimental pode ser reduzida por instrumento de regulamentação coletiva de trabalho ou por acordo escrito entre partes" (i.e., pode ser reduzida, mas não aumentada) e $339 .^{\circ}, \mathrm{n}^{\circ} 1$, o qual, sob a epígrafe "imperatividade do regime de cessação do contrato de trabalho" dispõe que "o regime estabelecido no
} 
Em síntese, como bem explicita Maria do Rosário Palma Ramalho, a regra geral continua a ser a supletividade das normas em relação aos instrumentos de negociação coletiva; porém, nas matérias contidas no art. $3 .^{\circ}$, n. $^{\circ} 3$, as convenções coletivas apenas podem afastar a norma legal se preenchidos dois requisitos: a) que a norma não seja absolutamente imperativa; b) que o regime a ser estabelecido seja mais favorável aos trabalhadores. $^{430} 431$ De acordo com António Monteiro Fernandes, a alteração legal representa a aceitação, pelo ordenamento português, das chamadas "normas definidoras de vantagens máximas ao trabalhador", as quais podem ser moduladas conforme as necessidades do caso concreto. ${ }^{432}$

Reiterem-se, por sua relevância, as matérias consideradas de imperatividade relativa elencadas pelo legislador: a) Direitos de personalidade, igualdade e não discriminação; b) Protecção na parentalidade; c) Trabalho de menores; d) Trabalhador com capacidade de trabalho reduzida, com deficiência ou doença crônica; e) Trabalhador estudante; f) Dever de informação do empregador; g) Limites à duração dos períodos normais de trabalho diário e semanal ${ }^{433}{ }^{434}$; h) Duração mínima dos períodos de repouso ${ }^{435}$, incluindo a duração mínima do período anual de férias ${ }^{436}$; i) Duração máxima do trabalho

presente capítulo não pode ser afastado por instrumento de regulamentação colectiva de trabalho ou por contrato de trabalho (...)". (Cf. supra, capítulo 3, item 3.3).

${ }^{430}$ Ramalho, Maria do Rosário Palma. Direito do Trabalho. Parte I - Dogmática Geral... Op. Cit., p. 279.

${ }^{431}$ No que tange, de outra parte, à relação das normas estatais com o contrato individual de trabalho, não houve modificações essenciais: continuam sendo relativamente imperativas, apenas admitindo derrogação in melius (cf. art. 3. ${ }^{\circ}$, n. ${ }^{\circ}$ 4), salvo se imperativas absolutas. Ainda, na relação entre instrumentos de regulamentação coletiva de trabalho e contrato de trabalho, permite o art. $476 .^{\circ}$ do CT/2009 que o contrato de trabalho se afaste do regime disposto na convenção coletiva, mas apenas para estabelecer regime mais favorável ao trabalhador - ou seja, retoma a situação anterior ao art. 531. ${ }^{\circ}$ do CT/2003, fazendo prevalecer a norma mais favorável neste aspecto. Ademais, estabelece o Código do Trabalho de 2009 que nova convenção coletiva só pode reduzir os direitos adquiridos na vigência de instrumento anterior se tiver caráter globalmente mais favorável (art. 530. ${ }^{\circ}$, n. 3 ), na linha do quanto disciplinado já pelo Código anterior.

${ }^{432}$ FERnANDES, António Monteiro. Direito do trabalho... Op. Cit., p. 130.

${ }^{433}$ A esse respeito, com relação ao teletrabalho, o art. $167 .^{\circ}$ do CT/2009 prevê que a duração inicial do contrato não poderá ser superior a três anos, “ou o prazo estabelecido em instrumento de regulamentação colectiva de trabalho" - em interpretação que sugere a possibilidade de aumento deste prazo pela convenção coletiva. Na mesma linha, o art. $218 .^{\circ},{ }^{\circ} .^{\circ} 2$, segundo o qual poderão ser estabelecidas outras hipóteses de isenção de horário por negociação coletiva.

${ }^{434} \mathrm{Em}$ sentido aparentemente oposto a referida regra, veja-se a redação do art. $203 .^{\circ}$, n. $^{\circ}$ 2, do CT/2009: "2 O período normal de trabalho diário de trabalhador que preste trabalho exclusivamente em dias de descanso semanal da generalidade dos trabalhadores da empresa ou estabelecimento pode ser aumentado até quatro horas diárias, sem prejuízo do disposto em instrumento de regulamentação colectiva de trabalho".

${ }^{435}$ Todavia, veja-se a redação do art. 213..$^{\circ}$ n. ${ }^{\circ}$ 2, aparentemente em contrariedade ao art. 3..$^{\circ}$ : "Por instrumento de regulamentação colectiva de trabalho, pode ser permitida a prestação de trabalho até seis horas consecutivas e o intervalo de descanso pode ser reduzido, excluído ou ter duração superior à prevista no número anterior, bem como pode ser determinada a existência de outros intervalos de descanso".

${ }^{436}$ Veja, de outra parte, que a penalidade para a não concessão das férias (pagamento em triplo do período não concedido) pode ser alterada in peius pela negociação coletiva (conforme interpretação conferida pelo 
dos trabalhadores nocturnos ${ }^{437}$; j) Forma de cumprimento e garantias da retribuição ${ }^{438}$; 1) Capítulo sobre prevenção e reparação de acidentes de trabalho e doenças profissionais e legislação que o regulamenta; m) Transmissão de empresa ou estabelecimento; n) Direitos dos representantes eleitos dos trabalhadores.

A princípio, as matérias elencadas pelo art. $3 .^{\circ}, \mathrm{n}^{\circ} 3$ parecem totalmente díspares e sem relação entre si. Entretanto, se analisadas de forma mais minuciosa, pode ser vislumbrado intuito de manutenção da proteção, por parte do legislador, de um núcleo duro de tutelas que correspondem ao "cerne" do Direito do Trabalho, envolvendo direitos de personalidade, maternidade, proteção às minorias trabalhadoras (menores, deficientes, etc.), tutela da saúde e segurança no trabalho, entre outras. No entender de Maria do Rosário Palma Ramalho, o legislador cuidou de estabelecer uma "solução de compromisso" 439 , mantendo o princípio da supletividade geral das normas laborais, mas atenuando referido princípio "com a exigência da maior favorabilidade em matérias mais significativas, do ponto de vista das garantias dos trabalhadores". 440

De qualquer forma, embora questionamentos doutrinários venham surgindo a respeito de tal rol de matérias ${ }^{441}$, é cediço que o art. $3 .^{\circ}$ do CT/2009 manteve o posicionamento do Código anterior, relativizando o princípio da norma mais favorável, para admitir a derrogação in peius de fontes estatais pela negociação coletiva, nas matérias não elencadas pelo artigo. ${ }^{442}$ Nas palavras de João Leal Amado, o dispositivo representou

art. 245 ${ }^{\circ}, \mathrm{CT} / 2009$ ). É nesse sentido, por exemplo, o entendimento de João Leal Amado (AMADO, João Leal. Contrato de Trabalho... Op. Cit., p. 46).

${ }^{437}$ Corroborando-se tal norma, veja-se o art. $223 .^{\circ}$, n. ${ }^{\circ}$ 2: "O período de trabalho nocturno pode ser determinado por instrumento de regulamentação colectiva de trabalho, com observância do disposto no número anterior, considerando-se como tal, na falta daquela determinação, o compreendido entre as 22 horas de um dia e as 7 horas do dia seguinte". Porém, o art. 224. ${ }^{\circ}$ afirma que se considerará trabalhador noturno aquele que prestar pelo menos três horas por dia de trabalho à noite, ou outro montante definido em negociação coletiva - em outras palavras, é permitido à negociação alterar a composição do trabalho noturno, podendo até mesmo prever limite superior a três horas para que o trabalhador seja considerado noturno.

${ }^{438} \mathrm{Da}$ mesma forma do quanto exposto na nota anterior, entende a doutrina ser possível a redução do

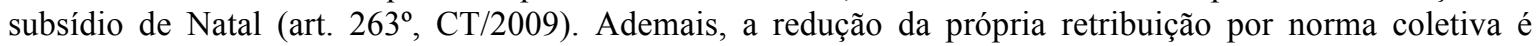
admitida pelo art. $129 .^{\circ}$, n. $^{\circ} 1 \mathrm{~d}$ do CT/2009, bem como a alteração dos limites das prestações não pecuniárias do salário (art. 259. ${ }^{\circ}$, n. ${ }^{\circ}$ 2) (cf. AMADO, João Leal. Contrato de Trabalho... Op. Cit., p. 46).

${ }^{439}$ Expressão também utilizada por FERNANDES, António Monteiro. Direito do trabalho... Op. Cit., p. 130.

${ }^{440}$ Ramalho, Maria do Rosário Palma. Direito do Trabalho. Parte I - Dogmática Geral... Op. Cit., p. 280.

${ }^{441}$ Nesse sentido, cf., e.g., o entendimento de João Leal Amado, para quem: a) mesmo nas matérias elencadas pelo art. $3^{\circ}, \mathrm{n}^{\circ} 3$ poderá haver derrogação in peius, desde que autorizado pela lei; e b) não apenas estas matérias são de imperatividade relativa, podendo a legislação trabalhista especificar outros casos em somente se admitirá modificação in melius. Em outras palavras, assim, o rol apresentado pelo dispositivo seria meramente exemplificativo (AMADO, João Leal. Contrato de Trabalho... Op. Cit., p. 52).

${ }^{442}$ Em sentido contrário, para quem o rol de matérias contido no item 3 de referido artigo, por sua amplitude, "acaba por representar, sob o ponto de vista prático, um verdadeiro retorno à situação anterior ao Código", cf. FERNANDES, António Monteiro Direito do Trabalho... Op. Cit., p. 130. Já João Leal Amado é categórico ao 
verdadeiro atestado de óbito do favor laboratoris relativamente à contratação coletiva, transformando as normas legais em normas "convénio-dispositivas", i.e., livremente afastáveis por convenção coletiva, ainda que desfavoravelmente ao trabalhador. ${ }^{443}$

Tal posicionamento poderia, aliás, ser justificado pela própria mudança da epígrafe sob a qual se encontram os dispositivos acima mencionados: como visto, enquanto o artigo $4^{\circ}$, do $\mathrm{CT} / 2003$, repousava sob epígrafe denominada "Princípio do tratamento mais favorável", no novo Código tal artigo passa a ser abarcado pela epígrafe "Relações entre fontes de regulação" - o que leva António Monteiro Fernandes a afirmar que "o tratamento mais favorável ao trabalhador deixa de constituir referencial interpretativo", não mais sendo possível a presunção de que uma norma admite variação em sentido mais favorável ao trabalhador, e sim que admite variação em qualquer dos sentidos. $^{444}$

De qualquer maneira, é importante ressaltar: sendo a supletividade a regra geral, e não se mostrando absolutamente claro o alcance das exceções previstas pelo n. ${ }^{\text {3 }}$, deve-se interpretar tais exceções de forma restritiva, sob pena de se comprometer o próprio princípio da autonomia coletiva que as alterações legislativas visaram a fortalecer. $^{445}$

Bernardo da Gama Lobo Xavier - embora, como visto, seja grande defensor das mudanças efetuadas pelo Código do Trabalho português desde 2003 salienta para a dificuldade de adequação de tais alterações ao atual sistema de relações sindicais existente em Portugal. Em seu entender, só se pode aceitar que as convenções coletivas disponham de maneira diversa que a lei "desde que se estabeleçam mecanismos de eficácia geral para conferir à contratação coletiva que modela o sistema legal uma possibilidade de normação e padronização das condições de trabalho na empresa" - o que

afirmar que "a verdade é que, enquanto regra de princípio, o favor laboratoris foi liquidado em 2003 e não foi ressuscitado em 2009". (AMADO, João Leal. Contrato de Trabalho... Op. Cit., p. 53)

${ }^{443}$ AMADO, João Leal. A Reforma do Código do Trabalho. CEJ-IGT. Coimbra Editora: Coimbra, 2004, pp. $117-118$.

${ }^{444}$ FERNANDES, António Monteiro. Direito do trabalho... Op. Cit., p. 130. E referida presunção, continua o autor, só será afastada se da norma legal resultar, inequivocadamente, que nenhuma variação é legítima ou só o será num dos sentidos possíveis.

${ }^{445}$ Cf. Ramalho, Maria do Rosário Palma. Direito do Trabalho. Parte I - Dogmática Geral... Op. Cit., p. 280. Em sentido contrário, o já mencionado posicionamento de AMADO, João Leal. Contrato de Trabalho... Op. Cit., p. 52. 
se mostra incompatível com o princípio da dupla filiação, vigente no ordenamento português. $^{446}$

Segundo referido princípio, as convenções coletivas de trabalho apenas obrigam o empregador que as subscreve ou que seja filiado à associação de empregadores celebrante, bem como os trabalhadores a seu serviço que também sejam membros de associação sindical celebrante (art. 496. ${ }^{\circ}$, CT/2009). Em outras palavras: a convenção coletiva somente gera efeitos em relação às pessoas filiadas às entidades sindicais signatárias, não possuindo a eficácia geral necessária para a padronização das condições de trabalho em uma determinada empresa (já que não se aplica aos empregados não filiados). ${ }^{447}$

O Código do Trabalho português, todavia, consagra meios de ampliação normativa dos textos das convenções coletivas de trabalho, a saber: o acordo de adesão e a portaria de extensão.

Por “acordo de adesão" (art. 504. $\left.{ }^{\circ}, \mathrm{CT} / 2009\right)$, entende-se o procedimento por meio do qual determinada associação sindical, associação de empregadores ou o próprio empregador adere a convenção coletiva ou a decisão arbitral em vigor. A adesão opera-se mediante acordo entre a entidade interessada e aquela ou aquelas que se lhe contraporiam na negociação da convenção, se dela tivessem participado.

Já a "portaria de extensão" (art. 514. ${ }^{\circ}$, CT/2009) corresponde a documento emitido pelo Ministro responsável pela área laboral por meio do qual se estende a aplicação, no todo ou em parte, de convenção coletiva ou decisão arbitral em vigor a empregadores e a trabalhadores integrados no âmbito do setor de atividade profissional definido naquele instrumento. Segundo o Código do Trabalho, referida extensão somente é possível mediante "ponderação de circunstâncias sociais e econômicas que a justifiquem, nomeadamente a identidade ou semelhança econômica e social das situações no âmbito da extensão e no do instrumento a que se refere" (art. 514. ${ }^{\circ}$, n. $^{\text {o }}$ 2) e

\footnotetext{
446 Xavier, Bernardo da Gama Lobo. Convenções colectivas, usos e o sistema de fontes de direito do trabalho (art. ${ }^{\circ} \mathbf{1}^{\mathbf{0}}$ e $\mathbf{4}^{\mathbf{0}}$ do CT)... Op. Cit., p. 239.

447 Conforme bem ressalta o autor, "nenhum sentido faz que (...) no mesmo estabelecimento alguns trabalhadores - os sindicalizados - estejam sujeitos ao regime menos favorável que o do CT e que outros possam invocar as respectivas disposições". Tais distinções mostram-se ainda mais marcantes em relação a tempo, espaço e função, bem como a cláusulas que instituam regalias não apropriáveis individualmente (XAvier, Bernardo da Gama Lobo. Convenções colectivas, usos e o sistema de fontes de direito do trabalho (art. ${ }^{\circ} \mathbf{1}^{\mathbf{0}}$ e $\mathbf{4}^{\mathbf{0}}$ do CT)... Op. Cit., p. 239).
} 
desde que não haja instrumento de regulamentação coletiva de trabalho negocial (art. $\left.515 .^{\circ}\right)$.

Porém, segundo o próprio Bernardo da Gama Lobo Xavier, referidos mecanismos de ampliação também se mostram inócuos a garantir a eficácia geral das normas coletivas que alteram o CT in peius: enquanto a adesão não pode ser efetuada individualmente pelo trabalhador, a extensão é demorada e nunca tem eficácia plena (já que é possível ao sindicato não aceitar a extensão proposta pelo Ministro). ${ }^{448}$ Ainda, questiona-se: seria legítimo aplicar, mediante portaria de extensão, cláusulas menos favoráveis a trabalhadores não filiados ao sindicato que as subscreveu ${ }^{449}$ De outra parte, seria crível admitir-se que, numa mesma empresa, trabalhadores filiados a sindicatos obtivessem regime laboral menos benéfico do que trabalhadores não filiados ${ }^{450}$

Pensando em outras soluções para o problema, o jurista português encontra dilemas similares. Assim, e.g., não é admitida pelo direito luso eventual cláusula no contrato de trabalho pela qual as partes determinem a aplicação dos conteúdos da convenção coletiva menos favorável à relação de trabalho in concreto (veja-se, nesse sentido, o disposto no art. 3. ${ }^{\circ}$, n. $\left.{ }^{\circ} 4, \mathrm{CT} / 2009\right) .{ }^{451}$ Da mesma forma, eventual aplicação informal da convenção coletiva menos favorável tende, obviamente, a expor as partes a riscos consideráveis. Porém, no entender do autor, neste ponto merece relevo a disciplina da força normativa dos usos laborais - única solução possível para conferir-se eficácia normativa geral às convenções menos favoráveis ao trabalhador.

Com efeito, considerando que os usos laborais não vêm previstos na Constituição da República Portuguesa enquanto fontes de direito, Lobo Xavier entende que estes somente têm força vinculante se associados a outro sistema normativo consagrado pela Constituição - no caso, as convenções coletivas. Assim, se a empresa (ou o setor) adotar prática uniforme de aplicar a todos os trabalhadores as convenções coletivas em vigor (independentemente de filiação), poderá ser sustentada a eficácia geral de suas cláusulas, baseada no acatamento e conformidade coletiva dos trabalhadores. Dessa forma,

\footnotetext{
448 XAVIER, Bernardo da Gama Lobo. Convenções colectivas, usos e o sistema de fontes de direito do trabalho (art. ${ }^{\circ} \mathbf{1}^{\mathbf{0}}$ e $\mathbf{4}^{\mathbf{0}}$ do CT)... Op. Cit., p. 239.

${ }^{449}$ Segundo Maria do Rosário Palma Ramalho, a resposta a tal indagação há de ser positiva, por força da própria lógica do sistema de extensão criado pelo ordenamento português (RAMALHO, Maria do Rosário Palma. Direito do Trabalho. Parte I - Dogmática Geral... Op. Cit., p. 303).

${ }^{450} \mathrm{Na}$ inspirada lição de Lobo Xavier, “ (...) será para os sindicatos inaceitável deixar seus associados em pior posição dos que andam à boleia (free drivers)". (XAVIER, Bernardo da Gama Lobo. Convenções colectivas, usos e o sistema de fontes de direito do trabalho (art. ${ }^{\circ} \mathbf{1}^{\mathbf{0}}$ e $4^{\mathbf{0}}$ do CT)... Op. Cit., p. 240

${ }^{451}$ XAVIER, Bernardo da Gama Lobo. Convenções colectivas, usos e o sistema de fontes de direito do trabalho (art. ${ }^{\circ} \mathbf{1}^{\mathbf{0}}$ e $\mathbf{4}^{\mathbf{o}}$ do CT)... Op. Cit., p. 239.
} 
a adoção da convenção de forma indiscriminada valerá como uso laboral, não sendo lícito "ao trabalhador que com ele se tenha conformado, permitindo pacificamente que as suas relações de trabalho vivam à sombra de dado $\mathrm{CCT}$, vir invocar o regime legal, a pretexto de não lhe ser aplicável a CCT". ${ }^{452}$

Independentemente de críticas e questionamentos doutrinários, fato é que, desde 2003, verdadeira revolução em prol do fortalecimento da negociação coletiva vem ocorrendo em Portugal: reconhece-se maturidade ao ente coletivo para, aos poucos, superar-se o modelo estritamente legislado por um sistema que reconhece a atuação das partes sociais como a melhor forma de garantir a efetividade da legislação trabalhista em concreto. $^{453}$

\subsubsection{A experiência espanhola}

No mesmo diapasão da experiência portuguesa, o direito espanhol vem, desde 1994, buscando conferir prevalência ao negociado sobre o legislado, em fenômeno que se convencionou chamar "despositivização do direito do trabalho". ${ }^{4} 4$

\footnotetext{
${ }^{452}$ XAVIER, Bernardo da Gama Lobo. Convenções colectivas, usos e o sistema de fontes de direito do trabalho (art. ${ }^{\circ} 1^{\mathbf{o}}$ e $4^{\mathbf{0}}$ do CT)... Op. Cit., p. 240.

${ }^{453}$ A corroborar o intuito de fortalecimento da autonomia privada coletiva, verifica-se, do art. $3 .^{\circ}$ do $\mathrm{CT} / 2009$, que as novas regras sobre a relação entre lei e convenção coletiva não se aplicam às denominadas "portarias de condições de trabalho" (art. 3. ${ }^{\circ}$, n. $^{\circ}$ 2). Referidas portarias correspondem a instrumentos emanados pelo Ministro competente em matéria laboral e pelo Ministro responsável pelo setor de atividade, e se destinam a regulamentar as condições de trabalho de determinado setor quando não exista sindicato responsável (incluem-se, portanto, na categoria de fontes heterônomas do Direito do Trabalho). Na versão original do art. $4 .^{\circ}$ do Projeto do Código do Trabalho de 2003, previa-se a supletividade geral da norma laboral, permitindo-se sua alteração in peius por qualquer instrumento de regulamentação coletiva do trabalho, autônomo ou heterônomo. Entretanto, aludida previsão foi declarada inconstitucional pelo Tribunal Constitucional português (Ac. TC n 306/2003, de 25 de junho), sob o argumento de que a supletividade apenas se justificaria em relação aos instrumentos autônomos de negociação coletiva, na medida em que estes, sim, representam a autonomia coletiva, direito fundamental dos trabalhadores. De outra parte, não se justifica que portaria administrativa possa afastar a lei, porque se reveste de caráter meramente regulamentar, encontrando-se em posição inferior àquela. A posição restou consolidada, agora, no mencionado art. $3 .^{\circ}, \mathrm{n} .^{\circ}$ 2, o qual dispõe que "as normas legais reguladoras de contrato de trabalho não podem ser afastadas por portaria de condições de trabalho". Não se deve confundir, porém, as portarias de condições de trabalho com as portarias de extensão - estas últimas, segundo bem ressalta Maria do Rosário Palma Ramalho, podem perfeitamente ensejar aplicação da disciplina convencional menos favorável a trabalhadores cujos sindicatos não participaram de sua negociação, na medida em que, a par de sua qualificação formal (atos regulamentares), deve-se levar em conta o objetivo por elas visado (uniformização da disciplina laboral num determinado setor profissional ou área de atividade) e a forma como perseguem tal objetivo (i.e., não mediante a celebração de novo instrumento, e sim pela extensão de regime convencional coletivo já existente). Trata-se, pois, de instrumentos de originalidade substancial (RAMALHO, Maria do Rosário Palma. Direito do Trabalho. Parte I - Dogmática Geral... Op. Cit., pp. 304-305).

${ }^{454}$ Expressão utilizada por Javier Thibault Aranda, nas aulas da disciplina "Reforma do Direito do Trabalho - A Experiência Espanhola", ministrada em agosto de 2008, no curso de pós-graduação da Faculdade de Direito da Universidade de São Paulo (USP). No mesmo sentido, Amparo Merino Segovia utiliza-se dos termos "dispositivización" e "deslegalización” para referir-se ao fenômeno (MERINO SEGOVIA, Amparo.
} 
Como já exposto em outra ocasião ${ }^{455}$, na Espanha, o princípio da norma mais favorável foi inicialmente reconhecido por doutrina e jurisprudência, sendo introduzido no direito positivo apenas em 1976, pelo art. 4.1 da Ley de Relaciones Laborales (LRL - Ley 16/1976). Posteriormente, viria a ser consagrado no art. 3.3 do atual Estatuto de los Trabajadores (Ley 8/1980), nos seguintes termos:

Art. 3.3. Los conflictos originados entre los preceptos de dos o más
normas laborales, tanto estatales como pactadas, que deberán
respetar en todo caso los mínimos de derecho necesario, se
resolverán mediante la aplicación de lo más favorable para el
trabajador apreciado en su conjunto, y en cómputo anual, respecto
de los conceptos cuantificables. ${ }^{456}$

Desde sua consagração, entretanto, o supracitado dispositivo legal foi alvo de ferrenhas críticas doutrinárias - especialmente por, supostamente, refletir realidade ultrapassada do Direito do Trabalho, não se adaptando de forma plena ao moderno sistema de fontes laborais. ${ }^{457}$ Assim é que, com fulcro no art. 37.1 da Constituição Espanhola de 1978 (que reconhece, expressamente, o direito à negociação coletiva e a força vinculante dos convênios coletivos), a Lei no 11/1994 modificou diversos dispositivos do Estatuto dos Trabalhadores, alterando drasticamente a relação entre lei e contratação coletiva - em manifesta revisitação do princípio do favor laboratoris.

A exposição de motivos da Lei $n^{0} 11 / 1994$, reconhecendo que o marco econômico em que as empresas espanholas desenvolvem sua atividade hoje "presenta notables diferencias con respecto al existente en 1980, año de la entrada en vigor del Estatuto de los Trabajadores" $" 458$ e que o esquema de garantias do Direito do Trabalho evidencia-se "cada vez más como una regulación puramente formal, que no sólo no sirve para proteger el empleo existente sino que abre una brecha cada vez mayor entre

Concurrencia de convenios colectivos y nueva articulación de la negociación colectiva: un estudio del artículo 84 LET. In BAYLOS GRAU, Antonio P (coord.). La reforma laboral de 1994. Cuenca: Univ de Castilla La Mancha, 1996, pp. 234-235).

${ }^{455}$ Cf. supra, capítulo 3, item 3.2.

456 "Os conflitos originados entre os preceitos de duas ou mais normas laborais, tanto estatais quanto negociadas, que deverão respeitar, em todo caso, os mínimos de direitos necessário, se resolverão mediante a aplicação da mais favorável para o trabalhador, apreciada em seu conjunto e, no cômputo anual, em relação aos conceitos quantificáveis" - tradução livre.

${ }^{457}$ Para referidas críticas, cf., UGUINA, Jesús R. Mercader. La silenciosa decadencia del principio de norma más favorable... Op. Cit., p. 21.

458 “apresenta notáveis diferenças com relação ao existente em 1980, ano da entrada em vigor do Estatuto dos Trabalhadores" - tradução livre. 
ocupados y desempleados" ${ }^{259}$, conclui pela necessidade de fortalecer a negociação coletiva (exteriorizada pelos convênios coletivos), por sua capacidade de aproximação " $a$ las diversas y cambiantes situaciones de los sectores de actividad y de las empresas". 460

Partindo-se de tais pressupostos - e segundo a própria exposição de motivos da Lei -, a reforma procurou abranger diversos momentos da relação laboral.

Inicialmente, objetivou-se modernizar a contratação de trabalhadores, de forma a torná-la mais específica às necessidades das empresas (especialmente as pequenas); nesse sentido, por exemplo, atribuiu-se à negociação coletiva a possibilidade de fixar o período do contrato de experiência (respeitados, porém, os limites legais). De outra parte, no que tange ao desenvolvimento do contrato de trabalho, foram disciplinadas regras envolvendo, sobretudo, remuneração e duração do trabalho, criando-se alguns limites indisponíveis, mas permitindo-se às partes a negociação dos demais.

O método encontrado pela Lei $n^{\circ} 11 / 1994$ para fortalecer a autonomia privada coletiva foi a transferência de diversas competências normativas, antes alocadas à lei, ao âmbito dos convênios coletivos. Potencializou-se, dessa forma, a utilização da negociação coletiva e propiciou-se a melhora de seus conteúdos, mediante a atribuição de novas faculdades de adaptação da normativa legal.

A seguir, apresentam-se, a título exemplificativo, algumas das novas competências atribuídas à contratação coletiva, após a reforma legal:

a) A já mencionada possibilidade de fixação da duração do período de experiência (art. 14.1, $\left.\mathrm{ET}^{461}\right)$;

b) A determinação da duração máxima de contratos por prazo determinado, bem como das hipóteses em que serão admitidos tais contratos (art. 15.1, $\mathrm{ET}^{462}$ );

\footnotetext{
459 “cada vez mais como uma regulação puramente formal, que não só não serve para proteger o emprego existente, sem que abra uma brecha cada vez maior entre ocupados e desempregados" - tradução livre.

460 "às diversas e mutáveis situações dos setores de atividade das empresas" - tradução livre.

461 Art. 14.1, ET: "Podrá concertarse por escrito un período de prueba, con sujeción a los límites de duración que, en su caso, se establezcan en los convenios colectivos" (grifou-se) - ("Poder-se-á negociar, por escrito, um período de experiência, sujeito aos limites de duração que venham estabelecidos nos convênios coletivos" - tradução livre).

462 Art. 15.1, ET. “(...) Por convenio colectivo se podrán determinar las actividades en las que puedan contratarse trabajadores eventuales, así como fijar criterios generales relativos a la adecuada relación entre el volumen de esta modalidad contractual y la plantilla total de la empresa. (...)" - "(...) Por convênio coletivo, poder-se-ão determinar as atividades em que se possam contratar trabalhadores eventuais, assim como fixar critérios gerais relativos à adequada relação entre o volume dessa modalidade contratual e a equipe total da empresa" - tradução livre).
} 
c) A especificação da estrutura do salário (morfologia salarial), com a indicação das parcelas que incorporarão ou não a remuneração (art. 26.3, $\mathrm{ET}^{463}$ ). Nesta matéria, também é admitida a criação de modelo de recibo de salários diferente daquele oficial, elaborado pelo Ministério do Trabalho (art. 29.1, $\mathrm{ET}^{464}$ );

d) A determinação da jornada de trabalho, respeitado o máximo de 40 horas semanais (art. 34.1, $\mathrm{ET}^{465}$ ). A grande inovação, aqui, é a possibilidade de, por meio de convênio coletivo, prever-se a distribuição irregular de $100 \%$ da duração do trabalho durante o ano, respeitando-se os períodos mínimos de descansos diários e semanais (sem negociação coletiva, é possível distribuir-se apenas $10 \%$ da duração). ${ }^{466}$ A corroborar referida norma, dita o Estatuto que o número de horas ordinárias de trabalho efetivo, como regra geral, não poderá ser superior a nove horas diárias - exceto se outra distribuição for acordada pela negociação coletiva $^{467}$

${ }^{463}$ Art. 26.3, ET. "Mediante la negociación colectiva o, en su defecto, el contrato individual, se determinará la estructura del salario, que deberá comprender el salario base, como retribución fijada por unidad de tiempo o de obra y, en su caso, complementos salariales fijados en función de circunstancias relativas a las condiciones personales del trabajador, al trabajo realizado o a la situación y resultados de la empresa, que se calcularán conforme a los criterios que a tal efecto se pacten. Igualmente se pactará el carácter consolidable o no de dichos complementos salariales, no teniendo el carácter de consolidables, salvo acuerdo en contrario, los que estén vinculados al puesto de trabajo o a la situación y resultados de la empresa" (grifou-se) - ("Mediante a negociação coletiva ou, em sua falta, o contrato individual, determinarse-á a estrutura do salário, que deverá compreender o salário base, como retribuição fixada por unidade de tempo ou de obra e, se for o caso, complementos salariais fixados em função de circunstâncias relativas às condições pessoais do trabalhador, ao trabalho realizado ou à situação e resultados da empresa, que serão calculados conforme os critérios que, para tanto, se pactuem. Igualmente, pactuar-se-á o caráter consolidado ou não de tais complementos salariais, não tendo caráter consolidado, salvo acordo em contrário, os que estejam vinculados ao posto de trabalho ou à situação e resultados da empresa" - tradução livre).

464 Art. 29.1, ET. "El recibo de salarios se ajustará al modelo que apruebe el Ministerio de Trabajo y Seguridad Social, salvo que por convenio colectivo o, en su defecto, por acuerdo entre la empresa y los representantes de los trabajadores, se establezca otro modelo que contenga con la debida claridad y separación las diferentes percepciones del trabajador, así como las deducciones que legalmente procedan" (grifou-se) - ("O recibo de salários ajustar-se-á ao modelo aprovado pelo Ministério do Trabalho e Seguridade Social, salvo se, por convênio coletivo ou, na sua falta, por acordo entre a empresa e os representantes dos trabalhadores, se estabeleça outro modelo que contenha a devida claridade e separação dos diferentes ganhos do trabalhador, assim como as deduções determinadas por lei" - tradução livre).

${ }^{465}$ Art. 34.1, ET. "La duración de la jornada de trabajo será la pactada en los convenios colectivos o contratos de trabajo. La duración máxima de la jornada ordinaria de trabajo será de cuarenta horas semanales de trabajo efectivo de promedio en cómputo anual" - ("A duração da jornada de trabalho será a pactuada nos convênios coletivos ou contratos de trabalho. A duração máxima da jornada ordinária de trabalho será de quarenta horas semanais de trabalho efetivo de média no cômputo anual" - tradução livre).

${ }_{466}$ Art. 34.2, ET. "Mediante convenio colectivo o, en su defecto, por acuerdo entre la empresa y los representantes de los trabajadores, se podrá establecer la distribución irregular de la jornada a lo largo del año. En defecto de pacto, la empresa podrá distribuir de manera irregular a lo largo del año el diez por ciento de la jornada de trabajo" - ("Mediante convênio coletivo ou, em sua falta, por acordo entre a empresa e os representantes dos trabalhadores, poder-se-á estabelecer a distribuição irregular da jornada ao longo do ano. Na ausência de pacto, a empresa poderá distribuir de maneira irregular ao longo do ano dez por cento da jornada de trabalho" - tradução).

${ }^{467}$ Art. 34.3, ET. "El número de horas ordinarias de trabajo efectivo no podrá ser superior a nueve diarias, salvo que por convenio colectivo o, en su defecto, acuerdo entre la empresa y los representantes de los 
e) Ainda em matéria de jornada, destacam-se a possibilidade de escolha entre compensação ou pagamento das horas extraordinárias (art. 35.1, $\mathrm{ET}^{468}$ ), a fixação do valor do adicional noturno (art. 36.2, $\mathrm{ET}^{469}$ ) e a qualificação dos intervalos intrajornada como tempo de trabalho ou não (art. 34.4, $\mathrm{ET}^{470}$ )";

f) A determinação do período de férias anuais, nunca inferior a 30 dias corridos (art. 38.1, $\mathrm{ET}^{471}$ ), o qual será fixado de comum acordo entre o empresário e o trabalhador, conforme o estabelecido na convenção coletiva (art. 38.2, $\mathrm{ET}^{472}$ );

g) A regulamentação da chamada "mobilidade funcional". Esta compreende a colocação do trabalhador para exercer funções inferiores ou superiores às habituais, por prazo determinado, diante de razões técnicas ou organizativas que a justifiquem. Neste caso, a lei prevê que, se a mobilidade para função superior

trabajadores, se establezca otra distribución del tiempo de trabajo diario, respetando en todo caso el descanso entre jornadas" - ("O número de horas ordinárias de trabalho efetivo não poderá ser superior a nove diárias, salvo se por convênio coletivo, ou, em sua falta, acordo entre a empresa e os representantes dos trabalhadores estabeleça-se outra distribuição do tempo de trabalho diário, respeitando, em todo caso, o descanso entre jornadas" - tradução livre).

${ }^{468}$ Art. 35.1, ET. "Mediante convenio colectivo o, en su defecto, contrato individual, se optará entre abonar las horas extraordinarias en la cuantía que se fije, que en ningún caso podrá ser inferior al valor de la hora ordinaria, o compensarlas por tiempos equivalentes de descanso retribuído" - ("Mediante convênio coletivo ou, em sua falta, contrato individual, optar-se-á entre abonar as horas extraordinárias na quantia fixada, que, em nenhum caso, poderá ser inferior ao valor da hora ordinária, ou compensá-las com tempos equivalentes de descanso" - tradução livre).

469 Art. 36.2, ET. "El trabajo nocturno tendrá una retribución específica que se determinará en la negociación colectiva, salvo que el salario se haya establecido atendiendo a que el trabajo sea nocturno por su propia naturaleza o se haya acordado la compensación de este trabajo por descansos" - ("O trabalho noturno terá uma retribuição específica que se determinará na negociação coletiva, salvo se o salário for estabelecido considerando que o trabalho seja noturno por sua própria natureza ou se tenha acordado a compensação desse trabalho com descansos" - tradução livre)

${ }^{470}$ Art. 34.4, ET. "Siempre que la duración de la jornada diaria continuada exceda de seis horas, deberá establecerse un período de descanso durante la misma de duración no inferior a quince minutos. Este período de descanso se considerará tiempo de trabajo efectivo cuando así esté establecido o se establezca por convenio colectivo o contrato de trabajo" - ("Sempre que a duração da jornada continuada exceda seis horas, deverá se estabelecer um período de descanso, dentro dela, de duração não inferior a quinze minutos. Esse período de descanso será considerado tempo de trabalho efetivo quando assim estabelecido por convênio coletivo ou contrato de trabalho" - tradução livre).

471 Art. 38.1, ET. "El período de vacaciones anuales retribuidas, no sustituible por compensación económica, será el pactado en convenio colectivo o contrato individual. En ningún caso la duración será inferior a treinta días naturales" - ("O período de férias anuais retribuídas, não substituível por compensação econômica, será o pactuado em convênio coletivo ou contrato individual. Em nenhum caso, a duração será inferior a trinta dias naturais" - tradução livre).

${ }^{472}$ Art. 38.2, ET. "El período o períodos de su disfrute se fijará de común acuerdo entre el empresario y el trabajador, de conformidad con lo establecido en su caso en los convenios colectivos sobre planificación anual de las vacaciones" - (“O período ou períodos de seu gozo será fixado de comum acordo entre o empresário e o trabalhador, em conformidade com o estabelecido nos convênios coletivos sobre planejamento anual das férias" - tradução livre). 
ultrapassar seis meses, o trabalhador poderá requerer sua promoção - salvo se o contrário resultar da negociação coletiva $(\operatorname{art} .39 .2, \mathrm{ET})^{473}$.

Segundo afirma Manuel Carlos Palomeque López, a peça básica que determina referidas alterações no sistema laboral espanhol é a necessidade de adaptação do corpo normativo regulador das relações de trabalho "al nuevo marco económico en que las empresas españolas desarrollan su actividad"474, representado pela profunda transformação dos sistemas produtivos, pelas exigências de convergência econômica europeia e pelas crises econômicas. Busca-se, em outras palavras, "mejorar la competitividad de las empresas y facilitar la creación de empleo". ${ }^{475}$

Por isso, conforme leciona Fernando Valdés Dal-Re, mediante a reforma de 1994, o Estado inicia uma revisão do campo das relações laborais sob duas vertentes: de um lado, "empieza a reenviar a la libertad plena o no condicionada de la autonomía colectiva (y a veces, simultánea o subsidiariamente, también a la autonomía individual) la ordenación de un buen número de condiciones de trabajo, antes reguladas por norma estatal" ${ }^{476}$; de outro, enriquece a tipologia das relações entre lei e convênio coletivo, na medida em que "la ley, además de ley única o ley mínima, actúa como ley supletoria o como ley básica" e "la dosis de derecho mínimo decrece y, en su lugar, se atribuye al convenio colectivo mayores posibilidades para derogar la regulación estatal y se le concede mayores oportunidades para integrar esa regulación". ${ }^{477}$

Mais uma vez, como se vê, está-se diante de autêntica revisitação do princípio da norma mais favorável em prol da competitividade empresarial. Nesse sentido,

\footnotetext{
${ }^{473}$ Art. 39.2, ET. "En el caso de encomienda de funciones superiores a las del grupo profesional por un periodo superior a seis meses durante un año u ocho durante dos años, el trabajador podrá reclamar el ascenso, si a ello no obsta lo dispuesto en convenio colectivo (...)" - ("No caso de exigência de funções superiores às do grupo profissional por um período superior a seis meses durante um ano ou oito meses durante dois anos, o trabalhador poderá reclamar a promoção, se esta não for obstada por convênio coletivo (...)" - tradução livre).

474 "ao novo marco econômico em que as empresas espanholas desenvolvem sua atividade" - tradução livre.

475 "melhorar a competitividade das empresas e facilitar a criação de emprego" - tradução livre (PALOMEQUE LÓPEZ, Manuel Carlos. El nuevo reparto funcional de territorios normativos entre la ley y el convenio colectivo. In Relaciones Laborales, $n^{\circ}$ 17-18, septiembre 1994, p. 246).

476 “começa a reenviar à liberdade plena ou não condicionada da autonomia coletiva (e, às vezes, simultânea ou subsidiariamente, também à autonomia individual), a ordenação de um bom número de condições de trabalho, antes reguladas por norma estatal" - tradução livre.

477 "a lei, ademais de lei única ou lei mínima, atua como lei supletória ou lei básica" e "a dose de direito mínimo decresce e, em seu lugar, atribuem-se ao convênio coletivo maiores possibilidade para derrogar a regulação estatal e se lhe concedem mais oportunidades para integrar essa regulação" - tradução livre para (VALDÉS DAL-RE, Fernando. El sistema español de negociación colectiva: entre la continuidad y el cambio. In Relaciones laborales: Revista crítica de teoría y práctica, $n^{\circ} 9,2011$, p. 106).
} 
a regra contida no art. 3.3 do Estatuto de los Trabajadores - embora ainda seja a regra geral - admite numerosíssimas exceções, pois somente se mostra aplicável nos casos em que a norma legal segue operando enquanto "norma mínima" (ou, na denominação tradicional da doutrina, de imperatividade relativa). ${ }^{478}$

Nesse contexto, atualmente, a doutrina espanhola debruça-se sobre a análise do relacionamento entre lei e norma coletiva perante o novo regime estatuído pela Lei 11/1994 - apontando para a existência de diversas "relações" entre referidas fontes do Direito do Trabalho.

Manuel Carlos Palomeque López, por exemplo, defende a existência três espécies de relações entre lei e negociação coletiva no novo sistema: relação de exclusão, de regulação compartilhada e de regulação exclusiva pelo convênio coletivo. ${ }^{479}$

Inicialmente, há relação de exclusão entre lei e convênio coletivo quanto às normas de regulamentação exclusiva pela lei (ou seja, matérias com reserva legal, totalmente afastadas do âmbito da negociação coletiva). Por seu turno, a regulação compartilhada entre lei e convênio coletivo opera-se de três formas distintas: a) regulação legal de mínimos que podem ser melhorados por convênio ("relação de suplementariedade"): a mais tradicional no meio jurídico trabalhista, na qual a lei estabelece condições mínimas que podem ser derrogadas in melius em favor do trabalhador por convenção coletiva (ou seja, a norma estatal mínima é melhorada por um suplemento convencional); b) Regulação legal imperativa configuradora dos aspectos básicos do instituto ("relação de complementariedade"): delimitação, em lei, dos contornos gerais da matéria, cabendo ao convênio coletivo detalhar sua disciplina; c) Regulação legal aplicável apenas na ausência de norma coletiva ("relação de subsidiariedade"): o convênio pode regular livremente a matéria, inclusive admitindo-se derrogação in peius, com aplicação apenas subsidiária da lei - a norma legal, neste caso, é "descartable por el convenio colectivo, que puede ocupar la materia en cuestión (norma legal dispositiva 'derogable' por convenio colectivo, en realidade desplazada de acuerdo con su propia previsión)". ${ }^{480}$ Finalmente, na regulação exclusiva pelo convênio coletivo, reconhece-se

\footnotetext{
${ }^{478}$ Nessas situações, aliás, afirma a doutrina espanhola que sequer há de se falar em aplicação do princípio da norma mais favorável, mas simples observância da hierarquia tradicional das normas jurídicas (Cf. UGUINA, Jesús R. Mercader. La silenciosa decadencia del principio de norma más favorable... Op. Cit., p. 27).

${ }^{479}$ PALOMEQUe LóPEZ, Manuel Carlos. El nuevo reparto funcional de territorios normativos entre la ley y el convenio colectivo... Op. Cit., p. 248.

480 "descartável pelo convênio coletivo, que pode abordar a matéria em questão (norma legal dispositiva "derrogável" por convênio coletivo, em realidade deslocada de acordo com a sua própria previsão)" -
} 
prioridade à competência reguladora da autonomia coletiva, sem submetê-la a quaisquer critérios ou limites. $^{481}$

Após explicitar as três relações acima descritas, o autor passa a apresentar exemplos de cada uma delas.

Inicialmente, na relação de exclusão, destacam-se matérias constitucionalmente reservadas à lei, como proibição à discriminação, direito de greve, liberdade de sindicalização, entre outras (art. 53.1, CE c/c arts, 22, 28 e 35, todos da CE). Trata-se, como se vê, de direitos fundamentais e básicos dos trabalhadores, razão pela qual sua regulamentação é vedada à negociação coletiva.

De outra parte, com relação à regulação compartilhada, destacam-se os seguintes exemplos: a) fixação do mínimo legal a ser melhorado por convenção coletiva: período mínimo interjornada de 12 horas (art. 34.3, ET) ${ }^{482}$; jornada máxima de 8 horas para menores de 18 anos (art. 34.3, ET, in fine) ${ }^{483}$; período de férias anuais de, no mínimo, 30 dias (art. 38.1, ET) ${ }^{484}$, entre outros; b) delimitação apenas dos contornos gerais pela lei:

tradução livre (PALOMEQUE LÓPEZ, Manuel Carlos. El nuevo reparto funcional de territorios normativos entre la ley y el convenio colectivo... Op. Cit., p. 248).

${ }^{481}$ Importante ressaltar que, em matéria de conflito entre convenções coletivas, a doutrina espanhola tende a afirmar que não se aplica a regra constante do art. $3^{\circ}$, do ET, e sim do art. 84 do mesmo diploma, segundo o qual "Un convenio colectivo, durante su vigencia, no podrá ser afectado por lo dispuesto en convenios de ámbito distinto salvo pacto en contrario, negociado conforme a lo dispuesto en el apartado 2 del artículo 83, y salvo lo previsto en el apartado siguiente" ("Um convênio coletivo, durante sua vigência, não poderá ser afetado pelo disposto em convênios de âmbito distinto, salvo pacto em contrário, negociado conforme o disposto no número 2 do artigo 83, salvo o previsto no número seguinte" - tradução livre). Em outras palavras, neste caso, prevalece a convenção negociada anteriormente, que não pode ser alterada por instrumento posterior (critério de prioridade temporal); porém, terminada a vigência da convenção mais antiga, poderá ser aplicada a mais recente (inclusive poderá ser negociada uma convenção de âmbito distinto). Veja-se que referido artigo faz menção a "pacto em contrário", levando à conclusão de que as próprias convenções podem chamar o princípio da norma mais favorável para resolver conflitos entre elas. A respeito do tema, cf, por todos, OJEdA AvilÉs, Antonio. Compendio de derecho sindical. ... Op. Cit., pp. 33-34.

${ }^{482}$ Art. 34.3, ET. "Entre el final de una jornada y el comienzo de la siguiente mediarán, como mínimo, doce horas. El número de horas ordinarias de trabajo efectivo no podrá ser superior a nueve diarias, salvo que por convenio colectivo o, en su defecto, acuerdo entre la empresa y los representantes de los trabajadores, se establezca otra distribución del tiempo de trabajo diario, respetando en todo caso el descanso entre jornadas" - ("Entre o final de uma jornada e o começo da seguinte haverá, no mínimo, doze horas de intervalo. O número de horas ordinárias de trabalho efetivo não poderá ser superior a nove diárias, salvo se, por convênio coletivo ou, em sua falta, acordo entre a empresa e os representantes dos trabalhadores, estabeleça-se outra distribuição do tempo de trabalho diário, respeitando, em todo caso, o descanso entre jornadas" - tradução livre).

${ }^{483}$ Art. 34.3, ET. “(...) Los trabajadores menores de dieciocho años no podrán realizar más de ocho horas diarias de trabajo efectivo, incluyendo, en su caso, el tiempo dedicado a la formación y, si trabajasen para varios empleadores, las horas realizadas con cada uno de ellos)” - (“(...) Os trabalhadores menores de dezoito anos não poderão realizar mais de oito horas diárias de trabalho efetivo, incluindo o tempo dedicado para a formação, e, se trabalharem para vários empregadores, as horas realizadas com cada um deles" tradução livre).

${ }^{484}$ V. nota 471 
contrato formativo, no qual cabe à convenção coletiva definir o número máximo de contratos a realizar, os postos de trabalho a cobrir, a duração máxima e mínima desses contratos, a retribuição mínima, etc. (nesse sentido, cf. art. 11, ET); c) aplicação subsidiária da lei: duração dos contratos de experiência (art. 14.1, ET) ${ }^{485}$ previsão de que as horas extras, fixadas por convenio, não poderão ser inferiores à hora ordinária (art. 35.1, $\mathrm{ET})^{486}$, etc.

Diversos são os exemplos, por outro lado, de matérias de regulação exclusiva pelo convênio coletivo - podendo-se fazer referência aos dispositivos acima colacionados, quando do início da análise da reforma operada pela Lei 11/1994.

Corroborando tal entendimento, Antonio Ojeda Avilés ${ }^{487}$ afirma que as reformas de 1994 e 2010 foram essenciais para determinar a alteração do critério de solução das relações entre fontes normativas coletivas, hoje podendo ser indicados nove critérios, sendo cinco excludentes (ou seja, que ensejam a aplicação de apenas uma das normas em conflito) e quatro integrativos (que ensejam sua aplicação conjunta).

Inicialmente, o autor aponta como critérios excludentes:

1. Critério da hierarquia, por meio do qual prevalece a norma de grau mais elevado. Incide, sobretudo, em conflitos de normas estatais entre si (e.g., leis e decretos) ou normas estatais absolutamente inderrogáveis e fontes privadas (como os direitos constitucionais acima mencionados);

2. Critério da favorabilidade, aplicável, como regra geral, aos conflitos entre normas de diferente hierarquia, salvo quando o legislador previr critérios diferenciados;

3. Critério da temporalidade, aplicável aos conflitos entre convenções coletivas, determinando-se a prevalência daquela que, primeiramente, se começou a negociar (considerado pelo autor ilógico e discutível, especialmente após a crise financeira de 2008). Ao contrário, se um instrumento normativo sucede a outro, prevalece o critério da lex posterior;

4. Critério da especialidade, que adquire grande importância com a reforma de 1994 e consiste em aplicar as regras da fonte mais próxima às situações a serem reguladas (em contrariedade, portanto, à regra da hierarquia). Segundo Ojeda

\footnotetext{
${ }^{485} \mathrm{~V}$. nota 461

${ }^{486} \mathrm{~V}$. nota 468

${ }^{487}$ OJEDA AVILÉS, Antonio. Compendio de derecho sindical... Op. Cit., pp. 25-31.
} 
Avilés, tal critério pode ser vislumbrado no art. 41.4, do $\mathrm{ET}^{488}$ (que trata da possibilidade de "modificación sustancial de condiciones de trabajo de carácter colectivo" ${ }^{489}$, inclusive para pior), e no art. 82.3, do $\mathrm{ET}^{490}$ (que, como visto, autoriza o afastamento da aplicação de convênios coletivos, na empresa, sobre determinadas matérias, se ocorrerem situações excepcionais);

5. Critério da supletividade, quando a lei determina que só se aplica na ausência de convênio coletivo (ou seja, em sentido ascendente, como ocorre no art. $35.1^{491}$, sobre horas extras) ou quando o legislador determina a regulamentação de determinada matéria a uma convenção coletiva ou, em sua falta, a fonte de nível inferior (ou seja, em sentido descendente, e.g., arts. 26.3, sobre morfologia salarial $^{492}$, e $34.2^{493}$, sobre distribuição da jornada de trabalho, ambos do ET).

De outra parte, são critérios integrativos (por solucionarem o conflito de maneira plural, ou seja, não afastando a aplicação de nenhuma norma):

1. Critério de complementariedade, quando ambas as normas se entendem apoiadas entre si para um objetivo comum. Nessa situação, uma norma faz remissão a outra para que aquela a complete - assim, e.g., quando o convênio coletivo regulamenta apenas aspectos gerais, remetendo ao contrato de trabalho a disciplina de particularidades. Após as reformas operadas na legislação espanhola a partir de 2010, tal critério perde sua importância, já que, atualmente, o legislador visa a

\footnotetext{
${ }^{488}$ Art. 41.4, do ET. "Sin perjuicio de los procedimientos especificos que puedan establecerse en la negociación colectiva, la decisión de modificación sustancial de condiciones de trabajo de carácter colectivo deberá ir precedida de un periodo de consultas con los representantes legales de los trabajadores, de duración no superior a quince días, que versará sobre las causas motivadoras de la decisión empresarial y la posibilidad de evitar o reducir sus efectos, asi como sobre las medidas necesarias para atenuar sus consecuencias para los trabajadores afectados. La consulta se llevará a cabo en una única comisión negociadora, si bien, de existir varios centros de trabajo, quedará circunscrita a los centros afectados por el procedimiento. La comisión negociadora estará integrada por un máximo de trece miembros en representación de cada una de las partes" - ("Sem prejuízo dos procedimentos específicos que possam ser estabelecidos na negociação coletiva, a decisão de modificação substancial de condições de trabalho de caráter coletivo deverá ser precedida de um período de consultas com os representantes legais dos trabalhadores, de duração não superior a quinze dias, que versará sobre as causas motivadoras da decisão empresarial e a possibilidade de evitar ou reduzir seus efeitos, assim como sobre as medidas necessárias para atenuar suas consequências para os trabalhadores afetados. A consulta levar-se-á a cabo em uma única comissão negociadora, enquanto, se existiram vários centros de trabalho, restará circunscrita aos centros afetados pelo procedimento. A comissão negociadora será integrada por um máximo de treze membros representantes de cada uma das partes". - tradução livre).

489 "modificação substancial das condições de trabalho de caráter coletivo" - tradução livre.

${ }^{490} \mathrm{~V}$. nota 524.

$491 \mathrm{~V}$. nota 468.

$492 \mathrm{~V}$. nota 463.

${ }^{493} \mathrm{~V}$. nota 466.
} 
fortalecer a negociação coletiva em âmbito empresarial, em detrimento da regulamentação pelo contrato de trabalho em si;

2. Critério de repartição, que consiste em atribuir funções distintas às fontes laborais, evitando sua colisão ou superposição. Trata-se de critério frequente na distribuição de competências processuais (e.g., para impugnar convenções coletivas, quando o sujeito é determinado a partir do motivo da impugnação);

3. Critério de contrapeso, mediante o qual se reconhece a prioridade de um dos poderes (normalmente o coletivo), mas submetido a um controle por parte do outro. Assim, por exemplo, estabelece-se na legislação espanhola que a taxa de negociação (algo similar à contribuição assistencial brasileira) poderá ser fixado por convenção coletiva, mas necessita do consentimento escrito do trabalhador para sua aplicação (art. 11 LOLS);

4. Critério da paridade, por meio do qual são atribuídas idênticas competências às fontes, delegando-se a elas próprias a solução dos conflitos. Trata-se de fórmula simples que coloca ambas as fontes em grau de paridade, mas pouco avançada, já que eventuais conflitos acabam sendo solucionados pelo Judiciário. Tal critério pode ser observado em diversos artigos do ET, como, e.g., o art. 34.1 (“ $L a$ duración de la jornada de trabajo será la pactada en los convenios colectivos o contratos de trabajo" $" 494$ - grifou-se); art. 35.4 ("La prestación de trabajo en horas extraordinarias será voluntaria, salvo que su realización se haya pactado en convenio colectivo o contrato individual de trabajo (...)",495 - grifou-se); art. 38.1 (“El período de vacaciones anuales retribuidas, no sustituible por compensación económica, será el pactado en convenio colectivo o contrato individual"496 grifou-se). ${ }^{497}$

Conforme se vê dos exemplos acima, a legislação espanhola atualmente prioriza critérios mais simples, como paridade e supletividade - justamente porque critérios como repartição, contrapeso e complementariedade exigem atuação intensa do legislador (para determinar competências e métodos de solução de conflitos) e das próprias

\footnotetext{
494 “A duração da jornada de trabalho será a pactuada nos convênios coletivos ou contratos de trabalho" tradução livre.

495 “A prestação de trabalho em horas extraordinárias será voluntária, salvo se sua realização for pactuada em convênio coletivo ou contrato individual de trabalho" - tradução livre.

496 “O período de férias anuais retribuídas, não substituível por compensação econômica, será o pactuado em convênio coletivo ou contrato individual" - tradução livre.

${ }^{497}$ OJEDA AVILÉs, Antonio. Compendio de derecho sindical. Op. Cit., pp. 25-31.
} 
partes sociais (que necessitam compor-se para permitirem a aplicação integral de tais métodos). Referidos critérios, ademais, coadunam-se com o intento de priorização da autonomia dos particulares, eis que implicam abandono de espaços de regulamentação estatal em prol da negociação coletiva.

Melhor desenvolvendo o tema, Manuel Carlos Palómeque López aponta para diversos pilares expressivos da autonomização da legislação, ou seja, do repasse de competências legislativas à negociação coletiva. ${ }^{498}$ Combinando-se o posicionamento do autor com a atual disciplina do Estatuto de los Trabajadores, podem-se destacar diversas novas formas de interação da fonte estatal e coletiva.

Inicialmente, a desaparição de regras de direito necessário dirigidas à negociação coletiva: até a reforma de 1994, o Estatuto de los Trabajadores contemplava diversas "obrigações" à negociação coletiva, ou seja, matérias que deveriam ser por elas regulamentadas. Agora, tais obrigações desaparecem.

Assim, e.g., o art. 25, ET, dispunha que "el trabajador tiene derecho a una promoción económica en los términos fijados en convenio colectivo o contrato individual" 499 (grifou-se); após as alterações, passa a prever que "el trabajador, en función del trabajo desarrollado, podrá tener derecho a una promoción económica en los términos fijados en convenio colectivo o contrato individual" ${ }^{\prime 500}$ (grifou-se). Em outras palavras: o direito certo à promoção previsto antes da Reforma transforma-se em eventual direito de origem contratual ou negocial, a ser criado pela autonomia privada (e não simplesmente regulamentado, como antes ocorria).

A disciplina das férias também se enquadra em referidas modificações (art. 38.2, $\mathrm{ET}^{501}$ ): a redação original impunha às convenções coletivas determinar critérios sobre planejamento das férias - e.g., preferência para trabalhadores com responsabilidades familiares. Agora, tais critérios desaparecem, limitando-se referido artigo a estabelecer que “el periodo o períodos de su disfrute se fijará de común acuerdo entre el empresario y el

\footnotetext{
${ }^{498}$ PALOMEQUe LóPEZ, Manuel Carlos. El nuevo reparto funcional de territorios normativos entre la ley y el convenio colectivo... Op. Cit., pp. 248 e ss.

499 "o trabalhador tem direito a um aumento salarial nos termos fixados no convênio coletivo ou contrato individual” - tradução livre.

500 “o trabalhador, em função do trabalho desenvolvido, poderá ter direito a um aumento salarial nos termos fixados no convênio coletivo ou contrato individual" - tradução livre.

${ }^{501} \mathrm{~V}$. nota 472.
} 
trabajador, de conformidad con lo establecido en su caso en los convenios colectivos sobre planificación anual de las vacaciones". 502

Porém, ainda se mantêm regras de direito necessário dirigidas à negociação coletiva, mas com soluções menos favoráveis ao trabalhador (em relação às previstas antes da Reforma). Assim, e.g., a disciplina das horas extras (art. 35.1, $\mathrm{ET}^{503}$ ): atualmente, o Estatuto prevê que o adicional de horas extras será fixado por norma coletiva, jamais sendo tal hora remunerada com valor inferior à hora normal; no diploma anterior, também se delegava à negociação coletiva a fixação do adicional, mas este deveria ser, pelo menos, $75 \%$ além da hora normal.

\section{Ainda, destaca-se a transformação do caráter imperativo da norma}

estatal em meramente dispositivo, com previsão de diversas normas aplicáveis apenas na inexistência de convenção coletiva (relação de subsidiariedade). Assim, e.g., a duração máxima do contrato de trabalho eventual - antes prevista imperativamente pela lei como não superior a 6 meses dentro de 12 meses, agora pode ser alterada pela negociação coletiva (art. 15.1, $\mathrm{ET}^{504}$ ); a possibilidade de, por meio de convenção coletiva, criar-se modelo de recibo individual de salários (antes, tal recibo deveria, obrigatoriamente, observar modelo do Ministério do Trabalho - art. 29.1, ET ${ }^{505}$ ); a distribuição do tempo de trabalho diário para além de nove horas por dia, mediante negociação coletiva, em contraposição à regra anterior de proibição à realização de mais de nove horas de trabalho por dia (art. 34.2, $\mathrm{ET}^{506}$ ); a alteração dos períodos de tempo para ascensão a categoria superior: na redação original, previa-se que o trabalhador que realizasse funções de categoria superior à sua por um período superior a 6 meses durante um ano ou 8 meses durante dois anos, poderia reclamar sua reclassificação para a função superior - agora, o art. 39.4, $\mathrm{ET}^{507}$ prevê que a negociação coletiva pode estipular prazos diferenciados para referida classificação; a duração do período de experiência, que agora é repassada

\footnotetext{
502 “O período ou períodos de seu gozo será fixado de comum acordo entre o empresário e o trabalhador, em conformidade com o estabelecido nos convênios coletivos sobre planejamento anual das férias" - tradução livre.

${ }^{503} \mathrm{~V}$. nota 468 .

${ }^{504}$ V. nota 462.

${ }^{505} \mathrm{~V}$. nota 464.

${ }^{506} \mathrm{~V}$. nota 466.

${ }^{507}$ Art. 39.4, ET. "El cambio de funciones distintas de las pactadas no incluido en los supuestos previstos en este artículo requerirá el acuerdo de las partes o, en su defecto, el sometimiento a las reglas previstas para las modificaciones sustanciales de condiciones de trabajo o a las que a tal fin se hubieran establecido en convenio colectivo" - ("A mudança de funções, distintas das pactuadas, não incluída nas hipóteses previstas neste artigo, requererá o acordo das partes ou, em sua falta, a submissão às regras previstas para as modificações substanciais das condições de trabalho ou as que para tal fim se tenham estabelecido em convênio coletivo" - tradução livre).
} 
integralmente aos convênios coletivos, apenas sendo aplicada a lei na inexistência daqueles (art. 14.1, $\mathrm{ET}^{508}$ ); entre outros exemplos.

Também ocorreu transferência de matérias originalmente destinadas à lei ao âmbito exclusivo da negociação coletiva, na chamada "autonomização plena" 509 . Como exemplo, tem-se a possibilidade de determinação da estrutura do salário por negociação coletiva (art. 26.3, $\mathrm{ET}^{510}$ ) - já que, antes da reforma, a morfologia salarial vinha fixada por normas regulamentares do Ministério do Trabalho.

Finalmente, ocorreu especificação legal de novos conteúdos de convenção coletiva ${ }^{511}$, como determinação de funções que admitem a celebração de contratos temporários (art. 15.1, $\mathrm{ET}^{512}$ ), livre fixação do adicional noturno (art. 36.2, $\mathrm{ET}^{513}$ ), criação de exigências formais para a dispensa fundada em motivo disciplinar (art. $\left.55.1, \mathrm{ET}^{514}\right)$, etc.

Em síntese: diversas foram as alterações efetuadas pela Lei ${ }^{\circ}$ 11/1994 para, nos termos de sua Exposição de Motivos, proceder à “cesión de la norma estatal en favor de la convencional" ${ }^{515}$ e ao fortalecimento da negociação coletiva ${ }^{516}$ - tudo em consonância com o art. 37.1 da Constituição Espanhola de 1978, o qual, como visto ${ }^{517}$,

\footnotetext{
${ }^{508}$ V. nota 461.

${ }^{509}$ PALOMEQUE LÓPEZ, Manuel Carlos. El nuevo reparto funcional de territorios normativos entre la ley y el convenio colectivo... Op. Cit., p. 252.

${ }^{510} \mathrm{~V}$. nota 463.

${ }^{511}$ Segundo Palomeque López, muitos desses conteúdos já decorriam da liberdade de contratação prevista no art. 85.1, do ET. Entretanto, agora, vêm previstos expressamente pela lei, numa tentativa de fomentar legalmente a negociação coletiva de referidas matérias. (PALOMEQUE LóPEZ, Manuel Carlos. El nuevo reparto funcional de territorios normativos entre la ley y el convenio colectivo..., Op. Cit., p. 255).

${ }^{512} \mathrm{~V}$. nota 462.

${ }^{513}$ V. nota 469.

${ }^{514}$ Art. 55.1. ET. "El despido deberá ser notificado por escrito al trabajador, haciendo figurar los hechos que lo motivan y la fecha en que tendrá efectos. Por convenio colectivo podrán establecerse otras exigencias formales para el despido (...)" - (“A dispensa deverá ser notificada por escrito ao trabalhador, contendo os fatos que a motivam e a data em que terá efeitos. Por convênio coletivo, poderão ser estabelecidas outras exigências formais para a dispensa" - tradução livre).

515 "cessão da norma estatal em favor da convencional" - tradução livre.

${ }^{516}$ Por óbvio, qualquer alteração legal que vise a atribuir maiores poderes ao sindicato envolve a necessidade de fortalecê-lo enquanto legítimo defensor do interesse coletivo. Para atender a tal mister, a Lei 11/1994 também efetuou revisão da disciplina da representatividade sindical, do regime jurídico das convenções coletivas (estatuindo-se novas regras sobre legitimação da empresa em convenções de âmbito superior ao empresarial - art. 87.3, ET; composição da comissão negociadora - art. 88, ET; etc.), bem como da capacidade de adaptação dos convênios às características de seu âmbito de aplicação (com regras sobre inaplicação das convenções - art. 82.3, ET; sobre conflitos entre convenções - art. 84.2, ET; sobre capacidade de a própria convenção estender sua duração - art. 86.3, ET; etc.).

${ }^{517} \mathrm{Cf}$. supra, capítulo 2, item 2.1.
} 
atribui à lei o dever de garantir o direito à negociação coletiva e a força vinculante dos convênios. ${ }^{518}$

Mais recentemente, a negociação coletiva sofreu nova reforma na Espanha, operada, inicialmente, pelo Real Decreto-Lei $n^{0} 7 / 2011$ (o qual consagra, em suas palavras "medidas urgentes para la reforma de la negociación colectiva",519) e, em seguida, pelo Real Decreto-Lei 3/2012 (sobre "medidas urgentes para la reforma del mercado laboral ${ }^{520}$ ). De fato, referidas medidas mostraram-se urgentes, pois visavam ao combate da grave crise econômica que assolou a Espanha a partir de 2008. O objetivo era a chamada "flexissegurança" instrumento de adaptação das condições laborais às necessidades concretas das empresas, e não um obstáculo.

Assim, reconheceu-se que - a despeito dos avanços ocorridos, especialmente, a partir de 1994 - a negociação coletiva ainda apresentava algumas disfunções que impediam sua eficiência “ $y$, particularmente, capacidad de adaptación a las condiciones cambiantes de la economía y del empleo y del propio modelo de relaciones laborales "522 523 , evidenciadas, sobretudo, pela existência de um número muito elevado de

\footnotetext{
518 Para mais informações sobre o tema da despositivização no direito espanhol, cf., além dos autores já citados, SAla Franco, Tomás. El derecho constitucional a la negociación colectiva. In CASAS BAAMONDE, María Emilia et al (org.). Las Transformaciones del Derecho del Trabajo en el Marco de la Constitución Española: Estudios en Homenaje al Profesor Miguel Rodriguez-Piñero y Bravo- Ferrer. Madrid: La Ley, 2006; LÓPEZ TERRADA, Eva. La descentralización de la estructura de la negociación colectiva y las posibilidades de su articulación. Valencia: Tirant Monografías, 2000.

519 "medidas urgentes para a reforma da negociação coletiva" - tradução livre.

520 "medidas urgente para a reforma do mercado de trabalho" - tradução livre.

521 Para maiores informações sobre o conceito e a abrangência da flexissegurança - que, por questões metodológicas, não será abordada neste trabalho -, cf., entre outros, SILVA, Luiz de Pinho Pedreira. Um novo modelo social: a flexissegurança. In LTr: revista legislação do trabalho, v. 69, n. 6, São Paulo, jun. 2005, pp. 645-647; MANNRICH, Nelson. Tendências atuais relativas ao âmbito pessoal do direito do trabalho em Portugal, Espanha e Brasil. In Revista de Direito do Trabalho, v. 34, no 130, abril-junho de 2008, São Paulo; BronZINI, Giuseppe. Come evitare la 'segmentazione' del mercato del lavoro: la filosofia della flexicurity e $i$ contratti a termine. In D\&L - Rivista critica di diritto del lavoro, no 4, ottobre-dicembre 2008, pp. 1111-1116; CostA, Alfredo Bruto da. O debate sobre a flexissegurança. In Questões Laborais, Ano XIV, Coimbra Editora, Coimbra, julho/dezembro de 2003, pp. 125-137; entre outros

522 “e, particularmente, capacidade de adaptação às condições cambiantes da economia e do emprego e do próprio modelo de relações laborais" - tradução livre (Cf. Exposição de Motivos do Real Decreto-Lei $7 / 2011)$

${ }^{523}$ No mesmo sentido, o posicionamento de Jesús Cruz Villalón, segundo o qual, de um modelo inicial em que a intervenção legal era central na fixação das condições de trabalho, passou-se a um processo paulatino de afastamento da atuação estatal e melhor delimitação dos conteúdos da negociação coletiva, que desembocou "en el panorama actual de muy fuerte impacto de lo negociado a través del complejo sistema de convenios colectivos en nuestro pais" - ("no panorama atual de forte impacto do negociado, por meio do complexo sistema de convênios coletivos no nosso país" - tradução livre) (CRUZ VILlaLón, Jesús. Texto y contexto de la reforma de la negociación colectiva 2011. In CRUZ VILLALÓN, Jesús et al. La Reforma de la negociación colectiva. Valladolid: Lex Nova, 2011, p. 19). Ainda, afirma Carlos L. Alfonso Mellado que "la negociación colectiva ha jugado un papel de adaptación y mejora que le es consustancial. Adaptación y
} 
convênios coletivos sobrepondo-se entre si (sem regras claras para solução de tais conflitos) e pela ausência de dinamismo dos convênios para adaptação da legislação laboral às necessidades empresariais.

Diante de tais pressupostos, e sintetizando-se as alterações efetuadas pelos Reais Decretos $n^{\circ} 7 / 2011$ e 3/2012, pode-se afirmar que quatro foram os principais pontos de reforma da legislação em matéria coletiva: 1) a possibilidade de, em situações específicas, afastar-se a aplicação da convenção coletiva em vigor; 2) a atribuição de "prioridade aplicativa" ao convênio coletivo celebrado em sede empresarial; 3) a redução dos conteúdos mínimos da negociação coletiva, permitindo-lhe maior mobilidade; e 4) a regulamentação do regime de ultratividade das convenções.

Inicialmente, o art. 82.3 do ET passou a permitir que, diante de causas econômicas, técnicas, organizativas ou de produção, seja afastada a aplicação dos convênios coletivos no caso concreto, em determinadas matérias, desde que mediante acordo entre empresa e representantes dos trabalhadores. Veja-se, com efeito, a redação de referido dispositivo:

Art. 82.3, do ET. "Los Convenios colectivos regulados por esta ley obligan a todos los empresarios y trabajadores incluidos dentro de su ámbito de aplicación y durante todo el tiempo de su vigencia. Sin perjuicio de lo anterior, cuando concurran causas económicas, técnicas, organizativas o de producción, por acuerdo entre la empresa y los representantes de los trabajadores legitimados para negociar un convenio colectivo conforme a lo previsto en el artículo 87.1, se podrá proceder, previo desarrollo de un período de consultas en los términos del artículo 41.4, a inaplicar en la empresa las condiciones de trabajo previstas en el convenio colectivo aplicable, sea este de sector o de empresa, que afecten a las siguientes materias: a) Jornada de trabajo; b) Horario y la distribución del tiempo de trabajo; c) Régimen de trabajo a turnos; d) Sistema de remuneración y cuantía salarial; e) Sistema de trabajo y rendimento; f) Funciones, cuando excedan de

complemento de la regulación legal alli donde ha sido necesario y mejora para los trabajadores de la legislación allí donde ésta, como es lo más normal en el ámbito laboral, se limita a garantizar mínimos que son mejorables en muchas empresas, sectores o territórios" ("a negociação coletiva desempenhou um papel importante de adaptação e melhora que é substancial. Adaptação e complemento da regulação legal ali onde foi necessário e melhora para os trabalhadores da legislação ali onde essa, como é o mais normal em âmbito laboral, limita-se a garantir mínimos que são melhoráveis em muitas empresas, setores ou territórios" tradução livre) (AlfONSO MELlADO, Carlos L.. La reforma de la negociación colectiva en la ley 3/2012: la vigencia del convenio y el problema de la ultraactividad. Palestra proferida na XXV Jornada de Estudio sobre Negociación Colectiva - La reforma laboral de 2012, Madrid, 4 de octubre de 2012, disponível online em

http://www.observatorionegociacioncolectiva.org/comunes/recursos/99998/doc126879_La_reforma_de_la_n egociacion_colectiva_en_la_Ley_3-

2012 La_vigencia_del_convenio_y_el_problema_de_la_ultraactividad..pdf, acesso em 17/11/14, às 18h). 
los límites que para la movilidad funcional prevé el artículo 39 de esta ley; g) Mejoras voluntarias de la acción protectora de la Seguridad Social". 524

Percebe-se que referida alteração confere flexibilidade não em relação à lei, mas dentro do âmbito da própria negociação coletiva: permite-se, às partes sociais, o afastamento, em concreto, de cláusulas normativas que elas próprias negociaram - tudo no intuito de adaptar a autonomia privada coletiva às necessidades empresariais. ${ }^{525}$

Nesse contexto, ademais, a nova redação do art. 84.2 do Estatuto de los Trabajadores confere prioridade aplicativa do convênio de empresa em relação a convênios de nível superior, quanto a determinadas matérias, in verbis:

Art. 84.2, ET. La regulación de las condiciones establecidas en un
convenio de empresa, que podrá negociarse en cualquier momento
de la vigencia de convenios colectivos de ámbito superior, tendrá
prioridad aplicativa respecto del convenio sectorial estatal,
autonómico o de ámbito inferior en las siguientes materias:

a) La cuantía del salario base y de los complementos salariales, incluidos los vinculados a la situación y resultados de la empresa.

524 “Os convênios coletivos regulados por esta Lei obrigam a todos os empresários e trabalhadores incluídos dentro de seu âmbito de aplicação e durante todo o tempo de sua vigência. Sem prejuízo do anterior, quando concorram causas econômicas, técnicas, organizativas ou de produção, por acordo entre a empresa e os representantes dos trabalhadores legitimados para negociar um convênio coletivo conforme o previsto no artigo 87.1, poderá a empresa, após prévio período de consultas nos termos do art. 41.1, não aplicar as condições de trabalho previstas no convênio coletivo, seja de setor ou de empresa, que afetem as seguintes matérias: a) Jornada de trabalho; b) Horário e distribuição do tempo de trabalho; c) Regime de trabalho em turnos; d) Sistema de remuneração e quantia salarial; e) Sistema de trabalho e rendimento; f) Funções, quando excedem os limites que prevê o artigo 39 para a mobilidade funcional; g) Melhorias voluntárias da ação protetora da Seguridade Social - tradução livre".

${ }^{525} \mathrm{O}$ próprio artigo 82 do ET melhor explicita as hipóteses em que os convênios poderão ser afastados, in verbis: "Se entiende que concurren causas económicas cuando de los resultados de la empresa se desprenda una situación económica negativa, en casos tales como la existencia de pérdidas actuales o previstas, o la disminución persistente de su nivel de ingresos ordinarios o ventas. En todo caso, se entenderá que la disminución es persistente si durante dos trimestres consecutivos el nivel de ingresos ordinarios o ventas de cada trimestre es inferior al registrado en el mismo trimestre del año anterior. Se entiende que concurren causas técnicas cuando se produzcan cambios, entre otros, en el ámbito de los medios o instrumentos de producción; causas organizativas cuando se produzcan cambios, entre otros, en el ámbito de los sistemas y métodos de trabajo del personal o en el modo de organizar la producción, y causas productivas cuando se produzcan cambios, entre otros, en la demanda de los productos o servicios que la empresa pretende colocar en el mercado" - ("Entende-se que concorrem causa econômicas quando, dos resultados da empresa, se depreenda uma situação econômica negativa, em casos como a existência de perdas atuais ou previstas, ou a diminuição persistente de seu nível de receitas ou vendas. Em qualquer caso, entender-se-á que a diminuição é persistente se, durante dois trimestres consecutivos, o nível de ingressos ordinários ou vendas de cada trimestre seja inferior ao registrado no mesmo trimestre do ano anterior. Entende-se que concorrem causas técnicas quando se produzam mudanças, entre outros, no âmbito dos sistemas e métodos de trabalho do pessoal ou no modo de organizar a produção, e causas produtivas quando se produzam mudanças, entre outros, na demanda dos produtos ou serviços que a empresa pretende colocar no mercado" - tradução livre). 
b) El abono o la compensación de las horas extraordinarias y la retribución especifica del trabajo a turnos.

c) El horario y la distribución del tiempo de trabajo, el régimen de trabajo a turnos y la planificación anual de las vacaciones.

d) La adaptación al ámbito de la empresa del sistema de clasificación profesional de los trabajadores.

e) La adaptación de los aspectos de las modalidades de contratación que se atribuyen por la presente Ley a los convenios de empresa.

f) Las medidas para favorecer la conciliación entre la vida laboral, familiar y personal.

g) Aquellas otras que dispongan los acuerdos y convenios colectivos a que se refiere el artículo 83.2. ${ }^{526}$

Essas são as matérias que, no entender da Exposição de Motivos do Real Decreto-Lei $\mathrm{n}^{\circ} 7 / 2011$, mostram-se mais próximas à realidade das empresas e, por isso "en aras de conseguir una mejor acomodación de las relaciones laborales al entorno económico y productivo en que se desenvuelven". De qualquer maneira, é importante ressaltar que, conforme a própria exposição de motivos, referido rol de matérias é meramente exemplificativo, podendo os convênios determinarem outras que, em seu entender, também devem obedecer à prevalência do convênio empresarial. ${ }^{527}$

Ainda, as reformas objetivam conferir maior dinamismo à negociação coletiva mediante a redução dos conteúdos mínimos dos convênios (com intuito de fomentar a liberdade de negociação) ${ }^{528}$ e recurso voluntário à mediação e arbitragem (antes

\footnotetext{
526 “A regulação das condições estabelecidas em um convênio de empresa, que poderá ser negociado em qualquer momento da vigência de convênios coletivos de âmbito superior, terá prioridade aplicativa em relação ao convênio setorial estatal, autônomo ou de âmbito inferior nas seguintes matérias: a) A quantia do salario base e dos complementos salariais, incluindo os vinculados à situação e resultados da empresa; b) $o$ abono ou a compensação das horas extraordinárias e a retribuição específica do trabalho em turnos; c) $\mathrm{O}$ horário e a distribuição do tempo de trabalho, o regime de trabalho em turnos e o planejamento anual das férias; d) A adaptação, ao âmbito da empresa, do sistema de classificação profissional dos trabalhadores; e) A adaptação dos aspectos das modalidades de contratação que se atribuem pela presente Lei aos convênios de empresa; f) As medidas para favorecer a conciliação entre a vida laboral, familiar e pessoal; g) Outras que disponham os acordos e convênios coletivos a que se refere o artigo 83.2" - tradução livre.

${ }^{527}$ Ademais, conforme ressalta Ignacio García-Perrote Escartín, a regra da prevalência do acordo de empresa pode ser afastada por norma coletiva superior (especialmente estatais), pois tais normas têm possibilidade de estabelecer regras sobre conflitos entre fontes (GARCÍA-PERROTE ESCARTín, Ignacio. La reforma de la negociación colectiva (el Real Decreto-Ley 7/2011, de 10 de junio, de medidas urgentes). In Revista de información laboral, $n^{\circ} 6,2011$, p. 8).

${ }^{528}$ Os quais vêm previstos no art. 85.3, ET: "Sin perjuicio de la libertad de contratación a que se refiere el párrafo anterior, los convenios colectivos habrán de expresar como contenido mínimo lo siguiente: a) Determinación de las partes que los conciertan. b) Ámbito personal, funcional, territorial y temporal. c) Procedimientos para solventar de manera efectiva las discrepancias que puedan surgir para la no aplicación de las condiciones de trabajo a que se refiere el artículo 82.3, adaptando, en su caso, los
} 
consideradas obrigatórias). Finalmente, acerca da ultratividade das convenções coletivas, a nova legislação pretende evitar que as regras de convênios cuja vigência já esteja superada perpetuem-se no tempo: estabelece que, transcorridos dois anos desde a denúncia do convênio, sem que se haja acordado um novo, aquele perderá sua vigência e será aplicado o convênio de âmbito superior (art. 86.3, ET).

Constata-se, em síntese, que o principal objetivo das reformas de 2011 e 2012 é aproximar a negociação coletiva das necessidades empresariais - na linha do quanto já fora buscado pela Lei 11/1994. ${ }^{529}$ Porém, os métodos utilizados por referidas reformas são diversos: enquanto a última pautou-se na revisão da interação da lei com a negociação coletiva, as primeiras buscaram modernizar os convênios coletivos considerados dentro de si, bem como as relações verificadas entre eles próprios.

De qualquer maneira, o intuito de flexibilização, por meio do fortalecimento da autonomia privada coletiva, é patente em todas as reformas experimentadas pela legislação espanhola - podendo-se, seguramente, afirmar que este país é o que melhor representa a caminhada na prevalência do negociado sobre o legislado.

procedimientos que se establezcan a este respecto en los acuerdos interprofesionales de ámbito estatal o autonómico conforme a lo dispuesto en tal artículo. d) Forma y condiciones de denuncia del convenio, así como plazo mínimo para dicha denuncia antes de finalizar su vigencia. e) Designación de una comisión paritaria de la representación de las partes negociadoras para entender de aquellas cuestiones establecidas en la ley y de cuantas otras le sean atribuidas, así como establecimiento de los procedimientos y plazos de actuación de esta comisión, incluido el sometimiento de las discrepancias producidas en su seno a los sistemas no judiciales de solución de conflictos establecidos mediante los acuerdos interprofesionales de ámbito estatal o autonómico previstos en el artículo 83" - ("Sem prejuízo da liberdade de contratação a que se refere o parágrafo anterior, os convênios coletivos deverão ter como conteúdo mínimo o seguinte: a) Determinação das partes que os celebram; b) Âmbito pessoal, funcional, territorial e temporal; c) Procedimentos para solucionar, de maneira efetiva, as discrepâncias que possam surgir para a não aplicação das condições de trabalho a que se refere o art. 82.3, adaptando os procedimentos que sejam estabelecidos, a esse respeito, nos acordos interprofissionais de âmbito estatal ou autonômico, conforme o disposto em tal artigo; d) Forma e condições de denúncia do convênio, assim como prazo mínimo para referida denúncia antes de finalizar sua vigência; e) Designação de uma comissão paritária da representação das partes negociadoras para resolver as questões estabelecidas na lei e outras que lhe sejam atribuídas, assim como estabelecimento dos procedimentos e prazos de atuação dessa comissão, incluída a sujeição das discrepâncias produzidas em seu seio aos sistemas judiciais de solução de conflitos estabelecidos mediante os acordos interprofissionais de âmbito estatal ou autonomia previstos no art. 83" - tradução livre).

${ }^{529}$ Tal objetivo leva Carlos L. Alfonso Mellado a questionar a constitucionalidade das reformas operadas pelo legislador espanhol desde 1994, sob o argumento de que a negociação coletiva é uma das facetas do direito constitucional à liberdade sindical. Assim, afirma o autor, é inviável a pretensão de converter a negociação coletiva em um instrumento predominantemente a serviço da empresa, sob pena de se comprometer-se o Estado de Direito como um todo (Alfonso Mellado, Carlos L.. La reforma de la negociación colectiva en la ley 3/2012: la vigencia del convenio y el problema de la ultraactividad... Op. Cit.). 


\subsubsection{A experiência italiana}

Ao contrário do que ocorre em Espanha e Portugal, as discussões acerca da prevalência do modelo negociado sobre o legislado, na Itália, ainda se mostram bastante embrionárias.

Conforme antes salientado, a legislação italiana consagra expressamente o princípio da norma mais favorável, desde 1924. ${ }^{530}$ Atualmente, o favor laboratoris pode ser encontrado no art. 40 do Statuto dei Lavoratori e, em doutrina e jurisprudência, ainda prevalece o entendimento da inderrogabilidade in peius da legislação estatal pelo contrato coletivo. $^{531}$

Leciona Luisa Galantino que "il contratto collettivo può derogare in melius, ma non in peius alle disposizioni di legge, a meno che queste ultime non siano assolutamente inderogabili, in quanto perseguono interessi publici". ${ }^{532}$ Em outras palavras: prevalece a regra da favorabilidade, exceto nos já mencionados casos de inderrogabilidade absoluta da norma, quando é vedado qualquer tipo de alteração, seja in melius, seja in peius (como ocorre, e.g., com normas de natureza previdenciária). ${ }^{533}$

Não por outra razão, aliás, Gino Giugni explica que os primeiros contratos coletivos surgiram com intuito de regulamentar mínimos de tratamento econômico e social para os contratos individuais de trabalho, caracterizando-se sua função normativa. ${ }^{534}$ A adaptabilidade da legislação estatal ao caso concreto, com efeito, não se enquadra, originalmente, entre as funções da negociação coletiva.

Porém, a partir da década de 1970, iniciam-se esforços de flexibilização da legislação trabalhista neste país - especialmente com a promulgação do Libro Bianco, em 2001.

O Libro Bianco corresponde a estudo doutrinário a respeito da situação do mercado de trabalho italiano, no qual foram apresentadas diversas propostas para a melhoria do emprego nesse país (que seriam posteriormente consagradas pela denominada Lei Biagi - Legge 14 febbraio 2003 n. 30). Em referido estudo, defendeu-se que o

\footnotetext{
${ }^{530}$ Cf. supra, capitulo 3, item 3.2.

${ }^{531}$ Cf., por todos, Galantino, Luisa. Diritto sindacale... Op. Cit., p. 167.

532 "o contrato coletivo pode derrogar in melius, mas não in peius, as disposições de lei, desde que estas não sejam absolutamente inderrogáveis, por perseguirem interesse público" - tradução livre.

${ }^{533}$ Galantino, Luisa. Diritto sindacale. 14 a edição. Torino: G. Giappichelli, 2006, p. 167.

${ }^{534}$ GiUgni, Gino. Diritto Sindacale... Op. Cit., p. 134. Tanto isso é verdade que, posteriormente, como se viu, a Lei Vigorelli determinaria que tais mínimos deveriam ser incorporados à legislação estatal, mediante promulgação de decretos (cf. supra, item 2.4.2).
} 
legislador nacional deveria adotar nova posição diante das alterações do mercado de trabalho: intervir tão-somente com uma "normativa-moldura", a ser complementada pela regulamentação autônoma em cada esfera territorial. ${ }^{535}$

A partir de então, superou-se o tradicional princípio do favor em algumas alterações legislativas.

Segundo narra Luisa Galantino, as exceções legais ao princípio da norma mais favorável, hoje verificadas na Itália, são de duas espécies: a) aquelas que vetam a autonomia coletiva de modificar, in melius, previsões contidas em lei; ou b) aquelas que introduzem processo denominado, pela autora, "delegificacione": normas que permitem à contratação coletiva modificar preceitos normativos ainda que em sentido menos favorável ao trabalhador. ${ }^{536}$

No que tange à primeira espécie, em março de 1977, foi promulgada lei que fixava "tetos" para a negociação coletiva, ou seja, limites máximos de direitos que poderiam ser negociados pelos sindicatos (Lei $n^{\circ}$ 91, de 31/03/1977). A inovação foi considerada inconstitucional por parte da doutrina italiana ${ }^{537}$, mas validada pela Corte Constitucional $^{538}$, sob o argumento de que, por vezes, o interesse público deve prevalecer sobre o interesse coletivo dos trabalhadores (já que este, embora amplo, sempre representa um interesse particular).

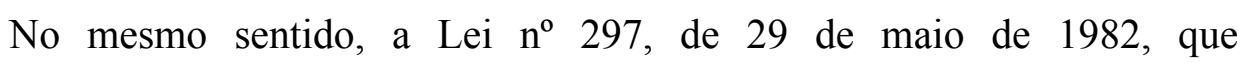
regulamenta a indenização a ser paga no caso de rescisão do contrato de trabalho. Segundo referida lei, a indenização deverá ser calculada ano a ano, dividindo-se a retribuição anual por 13,5 - divisor que não poderá ser modificado in melius pela negociação coletiva.

De outra parte, numerosos são os exemplos de derrogação ao princípio de favor que se enquadram na segunda espécie, de delegificacione.

Assim, por exemplo, a Lei $n^{0} 223$, de 23 de julho de 1991, a qual, regulamentando a alteração de funções de trabalhador, permite que acordos sindicais prevejam a colocação do empregado em função diversa daquela desenvolvida

\footnotetext{
${ }^{535} \mathrm{Na}$ inspirada lição de Amauri Mascaro Nascimento, a reforma italiana propôs que o ordenamento jurídico "deve ser sempre mais baseado sobre o management by objectives do que somente o management by regulation" (NASCimento, Amauri Mascaro. Compêndio de Direito Sindical... Op. Cit., p. 418).

${ }_{536}^{536}$ Galantino, Luisa. Diritto sindacale... Op. Cit., p. 168.

${ }_{537}^{537}$ SANTORO-PASSARELli, Giuseppe... Op. Cit., p. 107.

${ }^{538}$ Cort. Cost. 7 febbraio 1985, n. 34, disponível online em http://www.giurcost.org/decisioni/1985/0034s85.html.
} 
anteriormente, com intuito de evitar dispensas (em contradição ao que prevê o art. 2103, parágrafo $2^{\circ}$, do CC - o qual veda referidas alterações); o Decreto-legislativo $\mathrm{n}^{\circ} 276$, de 10 de setembro de 2003, que permite à contratação coletiva a celebração de contratos de trabalho com duração determinada, bem como de trabalho intermitente, além daqueles já previstos em lei; a Lei $\mathrm{n}^{\circ}$ 863, de 1984, que autoriza a celebração de "contratos de solidariedade defensiva", por meio dos quais o empregador pode reduzir o horário de trabalho e o salário, com a participação da Caixa de Integração para compensar parcialmente a diminuição da remuneração; entre outros.

Finalmente, segundo leciona a doutrina mais autorizada, além das funções normativas e obrigacionais do contrato coletivo (que seriam suas funções tradicionais), este também apresenta funções gerenciais (denominada "funzione gestionale"), utilizadas sobretudo em épocas de crise da empresa. ${ }^{539}$ Trata-se de cláusulas - plenamente admitidas por doutrina e jurisprudência - que permitem a escolha de empregados a serem dispensados, contratos de trabalho que serão suspensos, entre outras matérias. $^{540}$

Veja-se que os contratos acima mencionados (de funções gerenciais), entretanto, não produzem efeitos diretos sobre os contratos de trabalho - e, por tal razão, não são considerados pela jurisprudência constitucional como integrantes da espécie dos “contratos coletivos", previstos no art. 39, da Constituição. ${ }^{541}$

Segundo leciona Luisa Galantino, todas essas alterações têm por finalidade atenuar a rigidez legislativa, que se mostra excessiva em um contexto de reestruturação produtiva e automação da produção, considerando-se que os contratos coletivos "sono uno strumento assai meno rigido della legge e quindi più capace di adattarsi ai mutamenti della realtà economica" ${ }^{542}$ Entretanto, consoante acima salientado, não há verdadeira superação do modelo legislado pelo negociado, como pode ser verificado nos demais países antes estudado.

\footnotetext{
${ }^{539}$ Em expressão consagrada pela doutrina italiana (cf. SANTORO-PASSARELLI, Giuseppe. Dirito Sindacale... Op. Cit., p. 107; e GiUgni, Gino. Diritto Sindacale... Op. Cit., p. 146).

${ }^{540}$ Para mais exemplos, cf. GALANTINO, Luisa. Diritto sindacale... Op. Cit., pp. 126-128.

541 Nesse sentido, cf. Cort. Cost. 30 giugno 1994, n. 268 (disponível online em http://www.giurcost.org/decisioni/1994/0268s-94.html). O entendimento da jurisprudência é no sentido de que referidos contratos não detêm eficácia erga omnes, tal como determinado pelo art. 39, da Constituição, sendo aplicáveis apenas aos empregadores signatários - e, portanto, possuindo natureza exclusivamente procedimental.

542 "são instrumentos menos rígidos do que a lei e, por isso, mais capazes de adaptarem-se às mudanças da realidade econômica” - tradução livre (GALANTinO, Luisa. Diritto sindacale... Op. Cit., pp. 169).
} 


\subsubsection{A experiência francesa}

$\mathrm{Na}$ França, como visto, o princípio da proteção vem consagrado expressamente no art. 2251.1 do Code do Travail. ${ }^{543}$ Entretanto, sobretudo a partir da década de $1980^{544}$, o legislador vem autorizando, de forma cada vez mais frequente, derrogações convencionais de conteúdo mais ou menos favorável ao trabalhador, disseminando-se a ideia dos chamados "acordos derrogatórios" (accords dérogatoires).

Consoante já salientado, os acordos derrogatórios surgem, originariamente, em 1967, em Ordenação que permitiu a fixação de regras sobre jornada de trabalho menos favoráveis ao trabalhador mediante negociação coletiva. Posteriormente, em 1982, com as Leis Auroux, permite-se que as convenções coletivas reduzam os direitos dos trabalhadores em matéria de duração de trabalho e licenças remuneradas. ${ }^{545} 546$

A Lei Auroux, com efeito, fixou um patamar de 130 horas de trabalho extraordinário, que podem ser exigidas do trabalhador, sem necessidade de autorização por parte da Inspeção do Trabalho. Porém, autorizou às partes sociais a estipulação tanto de limite inferior, quando superior para referidas horas.

Mais recentemente, a Lei no 2003-6 (“Lei Fillon I"), de 3 de janeiro de 2003, permitiu a negociação coletiva sobre procedimentos de dispensa do trabalhador. Assim, por meio de acordos de empresas, poderão os atores sociais fixar as modalidades de informação e consulta do comitê de empresa sempre que ocorrer dispensa por motivo econômico de, pelo menos, 10 trabalhadores, num período de 30 dias.

É, porém, com a Lei de 4 de maio de 2004 (Lei 391/2004, também denominada Lei Fillon), que se opera verdadeira reforma no diálogo social das fontes no direito francês.

\footnotetext{
${ }^{543}$ Cf. supra, capitulo 3, item 3.2.

544 A respeito do tema, explica Antoine Jeummaud que "amorcé dès 1984, le mouvement de "flexibilisation" et d'allègement des coûts de main d'œuvre s'est accentué durant la première cohabitation (1986-1988). Privilégiant la faculté de substituer aux dispositions du droit étatique des règles négociées entre partenaires sociaux, il s'est traduit par une profusion législative et réglementaire." - ("iniciado em 1984 , o movimento de 'flexibilização' e de adaptação dos custos da mão de obra acentuou-se durante a primeira coabitação (1986-1988). Favorecendo a faculdade de se substituírem as disposições de direito estaduais por regras negociadas entre os parceiros sociais, traduziu-se em uma profusão legislativa e regulamentar" - tradução livre (Jeammaud, Antoine. Droit du Travail... Op. Cit.).

${ }^{545}$ Referida lei foi responsável pelo fortalecimento da negociação em nível empresarial, na medida em que estabeleceu a obrigatoriedade de, anualmente, as empresas detentoras de um representante sindical negociarem aspectos relativos à remuneração e ao tempo de trabalho.

${ }_{546}$ Acerca do tema, cf. VignEAU, Christophe. Le principe de faveur dans le régime du temps de travail en droit comparé... Op. Cit., p. 252.
} 
Referida lei representou mitigação ao princípio da norma mais favorável, na medida em que: a) permitiu, aos acordos e convenções de empresa, alterar a legislação in peius; b) permitiu, aos mesmos acordos, diante de certas condições, revogar convenções e acordos de nível superior (por exemplo, acordos de setor ou ramo).

Inicialmente, a Lei Fillon assegurou aos acordos ou convenções de empresa ou de estabelecimento a possibilidade de determinar as formas de aplicação de uma norma legal ou, até mesmo, derrogá-la. Trata-se, no entender da doutrina, dos denominados "contrats de proximité". 547

As matérias que admitem tais "aproximações" por parte da negociação coletiva vêm elencadas no art. 43 da Lei Fillon, entre as quais se destacam: a) fixação do período de experiência; b) determinação de funções que podem ser objeto de contrato de trabalho temporário; c) supressão da indenização a ser paga ao trabalhador temporário, no final da obra; d) alteração da disciplina relativa à jornada de trabalho; etc. Mais precisamente com relação a esta última, destacam-se alguns dispositivos do Code do Travail:

a) Art. L3121-34 ${ }^{548}$ : sobre duração diária do trabalho, permite o aumento da jornada de 10 horas mediante negociação;

b) Art. L3121-22 $2^{549}$ : prevê que o adicional de horas extras, tradicionalmente de $50 \%$, poderá ser reduzido por negociação coletiva (desde que o percentual nunca seja inferior a $10 \%$ );

c) Arts. L3132-14 a $19^{550}$ : preveem diversas possibilidade de revogação da lei quanto ao repouso semanal remunerado (criação de escalas, gozo em outros dias da semana, etc.); entre outros.

\footnotetext{
${ }^{547}$ TEYSSIÉ, Bernard. Droit du travail - Relactions collectives... Op. Cit., p. 286.

${ }^{548}$ Art. L3121-34, CT. "La durée quotidienne du travail effectif par salarié ne peut excéder dix heures, sauf dérogations accordées dans des conditions déterminées par décret" - ("A jornada normal de trabalho efetivo por trabalhador não pode exceder 10 horas, salvo derrogações acordadas sob condições determinadas por decreto" - tradução livre).

549 Art. L3121-22, CT. "Les heures supplémentaires accomplies au-delà de la durée légale hebdomadaire fixée par l'article L. 3121-10, ou de la durée considérée comme équivalente, donnent lieu à une majoration de salaire de $25 \%$ pour chacune des huit premières heures supplémentaires. Les heures suivantes donnent lieu à une majoration de $50 \%$. Une convention ou un accord de branche étendu ou une convention ou un accord d'entreprise ou d'établissement peut prévoir un taux de majoration différent. Ce taux ne peut être inférieur à $10 \%$ " - ("As horas suplementares cumpridas além da duração legal semanal fixada pelo artigo L. 3121 -10, ou da duração considerada equivalente, darão direito a um adicional salarial de $25 \%$ para cada uma das oito primeiras horas suplementares. As seguintes horas assegurarão adicional de $50 \%$. Uma convenção ou um acordo setorial ou uma convenção ou um acordo de empresa ou estabelecimento pode prescrever uma taxa diferente de aumento. Esta taxa não pode ser inferior a $10 \%$ " - tradução livre).

${ }_{550}$ Art. L3132-14, CT. "Dans les industries ou les entreprises industrielles, une convention ou un accord collectif étendu ou une convention ou un accord d'entreprise ou d'établissement peut prévoir la possibilité
} 
As alterações operadas pela Lei Fillon foram, posteriormente, complementadas pela Lei 2005-32, de 18 de janeiro de 2005, a qual, corroborando o quanto já previsto na Lei no 2003-6 (“Lei Fillon I'), autorizou a derrogação, mediante acordo de empresa, de grande parte da disciplina do Code du Travail relativa à informação e consulta do comitê de empresa no caso de dispensa por motivo econômico de, pelo menos, dez empregados, dentro de 30 dias.

Ademais do permissivo legal para alteração da legislação, a Lei Fillon também admitiu que acordos de abrangência mais restrita (por exemplo, de empresa) estabeleçam regras menos favoráveis do que acordos de abrangência maior (por exemplo, de setor ou ramo) - em manifesta aplicação do princípio da especialidade ou especificidade.

Na verdade, referida previsão já vinha contida em Lei de 13 de novembro de 1982, a qual permitia que acordos de empresa ou de estabelecimento adaptassem as modalidades de reajuste salarial previstas em convenções de abrangência maior para aplicação à empresa. Agora, porém, tal possibilidade é ampliada para outras matérias, excepcionando-se apenas aquelas relacionadas a salário mínimo, formação profissional, classificações de funções e proteção social.

Há, entretanto, limitações: o próprio acordo de nível superior pode estabelecer uma proibição a referida adaptação, quer de todas as suas cláusulas, quer de apenas algumas delas (conforme previsto no art. L2252-1). Ademais, há doutrinadores que entendem ser necessária a validação do acordo de derrogação, mediante questionamento prévio por parte do aplicador do Direito a respeito de três elementos: a) está-se diante de matéria passível de derrogação pela negociação coletiva (ou seja, não há proibição legal para tanto)?; b) em caso afirmativo, não há proibição à derrogação constante de

d'organiser le travail de façon continue pour des raisons économiques et d'attribuer le repos hebdomadaire par roulement" - ("Em indústrias ou empresas industriais, uma convenção ou um acordo coletivo estendido ou uma convenção ou um acordo de empresa de estabelecimento pode prever a possibilidade de organizar o trabalho de forma contínua, por razões económicas, e de atribuir o descanso semanal por escalas" - tradução livre).

Art. L3132-16, CT. "Dans les industries ou les entreprises industrielles, une convention ou un accord collectif de travail étendu ou une convention ou un accord d'entreprise ou d'établissement peut prévoir que le personnel d'exécution fonctionne en deux groupes dont l'un, dénommé équipe de suppléance, a pour seule fonction de remplacer l'autre pendant le ou les jours de repos accordés au premier groupe (...)" - ("Em indústrias ou empresas industriais, uma convenção ou um acordo coletivo de trabalho estendido ou uma convenção ou um acordo de empresa ou de estabelecimento pode prever que o pessoal de execução funcione em dois grupos, um dos quais, denominado 'equipe de substituição', terá o único propósito de substituir o outro durante o dia ou dias de descanso concedidos ao primeiro grupo" - tradução livre). 
instrumento superior?; c) em caso negativo, é efetivamente conveniente a aplicação do acordo derrogatório em detrimento do acordo superior, mais abrangente? ${ }^{551}$

De qualquer forma, tem prevalecido o entendimento de que os acordos derrogatórios possuem plena liberdade de adaptação das normas ao caso concreto, inclusive afastando-as se julgarem conveniente. Contudo, por óbvio, para sua celebração, é necessária expressa autorização legal, bem como ausência de vedação pelo instrumento superior. Ademais, somente pela via da negociação coletiva - jamais individual - é possível celebrar referidos acordos. ${ }^{552}$

Nova alteração na legislação francesa ocorreu em 2008: a Lei $n^{\circ} 67$, de 21 de janeiro de 2008 incorporou ao Código do Trabalho francês disposições preliminares que disciplinam o chamado "diálogo social".

Por força de tal alteração, os sindicatos passaram a desempenhar funções de extrema relevância, tanto na aplicação, quanto na própria criação da norma jurídica. Assim é que o art. L1 prevê, por exemplo, que todo projeto de reforma da legislação social deverá ser objeto de concertação prévia com as entidades sindicais e associações representativas de empregadores. Ademais, o art. L3 estabelece que, anualmente, as orientações de política do Governo sobre relações individuais e coletivas do trabalho devem ser apresentadas à Comissão de negociação coletiva, bem como deverá ser encaminhado ao Parlamento, pelo Governo, um relatório sobre todos os procedimentos de concertação social ocorridos no ano anterior.

Veja-se que referidas alterações, nitidamente, demonstram o intuito do legislador francês de fortalecer a negociação coletiva - não apenas enquanto moduladora da legislação estatal ao caso concreto, mas também como efetiva participante de sua elaboração. Acerca desse movimento experimentado pela legislação francesa, afirma Antoine Jeummaud:

"L'image d'un enrichissement continu des droits et garanties des salariés ne doit pas faire oublier ce que le droit du travail doit aux besoins du capitalisme (protection de la force de travail, modération de la domination sociale, pacification, sauvegarde de la concurrence) et à l'action patronale (...) Sur fonds de mise en question d'un droit du travail accusé de générer des coûts et rigidités excessifs, diverses modifications législatives ont prétendu

\footnotetext{
${ }^{551}$ A respeito, cf., por todos, MAZEAud, A. Droit du travail. $7^{\mathrm{a}}$ edição. Paris: Montchrestien, 2010, pp. 249250 .

${ }^{552}$ Conforme ressaltado pela doutrina, também não é possível que a redução de direitos legais decorra simplesmente de um costume ou de uma iniciativa unilateral do empregador (Cf. PINSON, Arnaud et SOUKPRASEUTH, Delphine. Retour sur l'ordre public en droit du travail et son application par la Cour de cassation... Op. Cit..).
} 
favoriser l'embauche en contexte de croissance du chômage et la compétitivité d'entreprises soumises à une concurrence internationale renforcée."

De fato, o movimento de adaptação da legislação estatal ao atual mercado de trabalho, pela via da negociação coletiva, é uma realidade - não apenas na França, mas em qualquer país que reconheça a instabilidade das modernas relações laborais e as dificuldades enfrentadas pela lei em regulamentá-las de forma a conciliar os interesses profissionais e patronais.

553 “A imagem de um enriquecimento contínuo dos direitos e garantias do trabalhador não deve fazer esquecer que o Direito do Trabalho se presta às necessidades do capitalismo (proteção à força de trabalho, moderação da dominação social, pacificação, proteção da concorrência) e à ação do empregador (...). Diante da acusação, ao Direito do Trabalho, de gerar custos excessivos e rigidez, várias mudanças legislativas objetivaram promover o emprego, em um contexto de aumento do desemprego e de competitividade das empresas sujeitas a uma maior concorrência internacional" - tradução livre (JEAMMAUD, Antoine. Droit du Travail... Op. Cit). 


\section{A experiência brasileira}

\subsection{A necessária devolução de poder aos corpos sociais}

O estudo dos modelos de prevalência do negociado sobre o legislado em outros países leva, naturalmente, ao questionamento: não seriam tais modelos aplicáveis no Brasil? Atentando aos constantes problemas econômicos enfrentados pelo país, não seria interessante revisitar o diálogo das fontes trabalhistas em terras pátrias - até com o intuito de prevenir futuras crises? Em caso afirmativo, como compatibilizar a necessidade de remodelação da legislação trabalhista com o fato de que os sindicatos brasileiros ainda enfrentam profunda crise de representatividade (e - por que não? - de identidade)?

Independentemente do ordenamento jurídico em exame, é certo que a análise da normativa aplicável à relação de emprego pressupõe a interpretação dessa relação sob o ponto de vista sociológico e político - e, nesse aspecto, tal relação pode ser visualizada como autêntica manifestação de poder. ${ }^{554}$

Aludido poder desdobra-se em três esferas, exteriorizadas por três diferentes sujeitos, que, juntos, ditam o passado, o presente e o futuro das relações laborais: o Estado, que exerce poder sobre os particulares na regulamentação das condições de trabalho; o empregador, que exerce poder sobre o trabalhador, na direção da prestação de seus serviços; e as próprias partes sociais, que exercem poder negocial na adaptação de normas ao caso em concreto.

A depender da prevalência de uma ou outra dessas esferas (quer dizer, do centro de irradiação do poder), têm-se indícios do tipo de ordenamento jurídico que se quer construir. Se quem prevalece é o Estado, está-se diante de legislação autoritária e corporativista; se é o empregador, de ordenamento de cunho liberal; se são as partes sociais, de corpo legal intervencionista com feição meramente promocional, atribuindo-se

${ }^{554}$ Conforme leciona Romita, Arion Sayão. O Princípio da Proteção em Xeque... Op. Cit.. 
ampla participação ao sindicato (ou a outros corpos sociais) na feitura das leis, em governo democrático. ${ }^{555}$

A história da legislação trabalhista brasileira - após um breve período de viés estritamente liberal - demonstra a constante prevalência do Estado enquanto detentor do poder de regulamentação das relações laborais, com inclinações corporativistas.

Com efeito, o surgimento da legislação trabalhista em terras pátrias coincide com o modelo do Estado Novo - razão pela qual a Consolidação das Leis do Trabalho "tem a marca da doutrina que fascinou os detentores do poder, após o golpe de Estado de 10 de novembro de 1937". ${ }^{556}$ Assim, embora jamais se tenha instituído, no Brasil, sistema idêntico ao italiano, "a proclamação do trabalho como dever social, os direitos individuais ampliados e garantidos pela Constituição, o sindicato atraído para a esfera do Estado e a solução dos conflitos coletivos pela magistratura especial do trabalho" denunciavam a filiação política e o embasamento ideológico da legislação à Carta del Lavoro. $^{557} 558$

E referido embasamento ideológico, por óbvio, não oferecia outra alternativa senão a centralidade do poder normativo na figura estatal. Por isso, já se afirmou, em outro momento deste trabalho, que o ambiente laboral brasileiro nunca se mostrou propício ao desenvolvimento de autêntico pluralismo jurídico, existindo simples pluralidade de fontes normativas, todas concentradas no Estado interventor. ${ }^{559}$

Nesse sentido, como bem expõe Arion Sayão Romita, considerando que o Estado também concentra o poder econômico, não há como desvencilhar a legislação trabalhista protetora dos interesses do capital: é do núcleo poder estatal-econômico "que

\footnotetext{
${ }^{555}$ Acerca do tema, cf. RomitA, Arion Sayão. O Princípio da Proteção em Xeque... Op. Cit..

${ }^{556}$ BARros, Cássio Mesquita. Modernização da CLT à luz da realidade brasileira. In Revista da Faculdade de Direito da Universidade de São Paulo - FDUSP, vol. 86, 1991, p. 100.

${ }_{557}$ BArros, Cássio Mesquita. Modernização da CLT à luz da realidade brasileira... Op. Cit., p. 101.

${ }^{558}$ Assim é que a Exposição de Motivos do Decreto 1402/43, incorporado à CLT, dispunha que o sindicato vivia em torno do Ministério do Trabalho "nele nascendo, com ele crescendo, ao lado dele se desenvolvendo e nele se extinguindo".

${ }^{559}$ Cf. supra, capítulo 1, item 1.5. Nesse sentido, Octávio Bueno Magano ressalta que, no Brasil, a transposição do corporativismo para o pluralismo democrático nunca chegou a se consumar plenamente: se a Constituição de 1946 consagrava a liberdade de iniciativa, mantinha a concepção de que os sindicatos exercem funções delegadas de poder público. Ademais, a prevalência da Justiça do Trabalho como único órgão capaz de conferir soluções aos dissídios trabalhistas também conflita com a ideia de pleno pluralismo, já que sistemas efetivamente pluralistas priorizam mecanismos de autotutela e autocomposição. Segundo o autor, nos Estados Unidos, por exemplo, o governo apenas interfere nas relações trabalhistas para garantir o direito à livre organização sindical. Criados sindicatos, estes têm ampla liberdade para negociar condições de trabalho e tirar proveito de mecanismos de pressão. O governo não intervém no conteúdo das relações de emprego (MAGANO, Octávio Bueno. Liberalismo, corporativismo, pluralismo e neo-corporativismo... Op. cit., pp. 58-59).
} 
emana a legislação dita protecionista que visa, em consequência, a proteger os exercentes daquele poder: os agentes estatais e os empresários". ${ }^{560}$ Não por outro motivo, "para compensar a inatividade a que condenaria os trabalhadores como classe sufocando o sindicato", o Estado enriqueceu o patrimônio individual dos empregados com um número incontável de direitos. ${ }^{561}$

Por isso, também em terras brasileiras, diversos autores vêm reconhecendo a necessidade de fortalecer o "contra-poder" dos sindicatos ${ }^{562}$, pugnando pela revisitação do sistema de fontes do Direito do Trabalho. A ideia é conferir prevalência ao negociado sobre o legislado, em determinadas matérias - sobretudo para fazer frente a períodos de retração econômica e novas situações laborais, totalmente diferentes daquelas vivenciadas à época do Estado Novo. ${ }^{563}$

Assim, e.g., segundo Nelson Mannrich, a preocupação maior do Direito do Trabalho deveria voltar-se à democratização das fontes de produção da norma, para que seja resgatado o espaço contratual indevidamente invadido pelo Estado, conferindo às partes sociais a possibilidade de, junto com este, fazerem as necessárias adaptações à normativa trabalhista. ${ }^{564}$ No mesmo sentido, para Walküre Lopes Ribeiro da Silva, no atual contexto socioeconômico em que se insere o Direito do Trabalho, "o melhor modo de obter sucesso na regulação social é a renúncia à imposição unilateral da norma jurídica, convidando-se os atores sociais a auto-regularem seus interesses", redimensionando a interação das fontes desse ramo do Direito. ${ }^{565}$

Para Arion Sayão Romita, em uma ordem democrática, inexiste possibilidade de antagonismo ou oposição entre o negociado e o legislado - haveria apenas o negociado, pois o legislador se limitaria a promover as condições em que o negociado poderia expandir-se, atuando como mediador e arbitrando os conflitos. ${ }^{566}$ Luiz Carlos

\footnotetext{
${ }^{560}$ Romita, Arion Sayão. O Princípio da Proteção em Xeque... Op. Cit.

${ }^{561}$ BARros, Cássio Mesquita. Modernização da CLT à luz da realidade brasileira... Op. Cit., p. 101.

${ }^{562}$ Único, no entender de Arion Sayão Romita, apto a contrabalançar a posição de desigualdade social em que o trabalhador se encontra em face do Estado e do empresário (RomitA, Arion Sayão. O Princípio da Proteção em Xeque... Op. Cit.).

${ }^{563}$ Aliás, já em 1990, quando a CLT completava 47 anos, Cássio Mesquita Barros afirmava que referido diploma encontrava-se defasado, não mais se adequando à realidade brasileira, muito diferente daquela em que nasceu (BARros, Cássio Mesquita. Modernização da CLT à luz da realidade brasileira... Op. Cit., p. $103)$.

${ }^{564}$ MannRICH, Nelson. Pluralismo jurídico e Direito do Trabalho... Op. Cit., p. 17.

565 Silva, Walküre Lopes Ribeiro da. Autonomia privada coletiva e o direito do trabalho. In Revista de Direito do Trabalho, $\mathrm{n}^{\circ}$ 97, ano 26 - jan/mar de 2000, São Paulo, Revista dos Tribunais, pp. 36 e ss.

566 Romita, Arion Sayão. O Princípio da Proteção em Xeque... Op. Cit.. No mesmo sentido, cf., ainda, Silva, Otavio Pinto e. A função do direito do trabalho no mundo atual. In CorReIA, Marcus Orione
} 
Amorim Robortella sustenta que a indisponibilidade de direitos adquiridos é incompatível com o dinamismo do mercado de trabalho, e que, observadas determinadas condições, é preciso conferir à negociação coletiva "a aptidão de modificar as condições contratuais, inclusive reduzindo determinados direitos". 567

O autor afirma, ainda, que a proteção dos trabalhadores representa uma conquista do Estado Social e Democrático de Direito, pois visa à eliminação da desigualdade social e econômica entre o empregado e o empregador e à substituição da noção de igualdade meramente formal pela igualdade material - e, sob esse viés, longe de "desconfiar" dos atores sociais, o Estado neles deposita confiança, compreendendo o entendimento direto das classes como a melhor maneira de compor interesses comuns.

Dessa forma, o antagonismo entre as classes é reconhecido, e, em lugar da solução de cima, por via autoritária, "o Estado, mediante legislação de suporte, estimula a organização da classe trabalhadora para que esta alcance pela via da negociação com a classe patronal a realização de seus legítimos interesses". Admite-se, portanto, que não cabe ao Estado-legislador ou ao Estado-juiz, proteger o empregado, mas sim à própria classe trabalhadora, organizada em entidades sindicais livres e representativas. ${ }^{568}$

A já citada Walküre Lopes Ribeiro da Silva reforça que a negociação coletiva deve ser utilizada como instrumento de adaptação do sistema de relações de trabalho, pois o sindicato é capaz de garantir a manutenção de regras e princípios jurídicos fundamentados na ordem pública, "que reflitam valores considerados essenciais para o bom funcionamento da sociedade e não-submetidos à lei do mercado". 569 Para Otávio Pinto e Silva, a grande vantagem da contratação coletiva em relação às fontes estatais do Direito do Trabalho é que aquela melhor se adapta "ao dinamismo do mundo do trabalho, um mundo onde as situações se modificam com muita rapidez, com repercussão direta nos interesses das coletividades". 570

Gonçalves (Org.). Curso de Direito do Trabalho - Teoria Geral do Direito do Trabalho. V. 1. São Paulo: LTr, 2007, pp. 143-154 e PASTORE, José. Atritos entre a Lei e a Realidade no Campo Trabalhista In Velloso, Carlos Mário da Silva et al (Coord.). Princípios Constitucionais Fundamentais. São Paulo: Lex Editora, 2005.

${ }^{567}$ ROBORTELLA, Luiz Carlos Amorim. O conceito moderno de negociação coletiva. In ROBORTELLA, Luiz Carlos Amorim. Direito Sindical Brasileiro: estudos em homenagem ao Prof. Arion Sayão Romita. São Paulo: LTr, 1998, p. 241.

${ }^{568}$ RomitA, Arion Sayão. O Princípio da Proteção em Xeque... Op. Cit..

${ }^{569}$ Silva, Walküre Lopes Ribeiro da. Autonomia Privada Coletiva... Op. Cit., pp. 151-152.

${ }^{570}$ Silva, Otavio Pinto e. Fontes do direito do trabalho... Op. Cit., p. 210. 
Ives Gandra da Silva Martins Filho chama atenção para a atual função do Direito do Trabalho de promover o bem comum. E, em seu entender, deriva do bem comum a relação de subsidiariedade entre o Estado e as partes sociais, daí advindo o ideal de que as normas sejam prioritariamente estabelecidas pela negociação coletiva, cabendo ao Estado apenas a legislação supletiva na ausência de normas autônomas. Em suas palavras: "o Estado somente deve intervir nesse jogo quando as partes em disputa não são capazes de jogar civilizadamente ou chegar a uma solução de composição". 571572

Sobressai, portanto, a negociação coletiva como importante instrumento de flexibilização - não desregulamentação ou precarização, ressalte-se - de determinados direitos trabalhistas. ${ }^{573}$ Para Cássio Mesquita Barros, "o Direito do Trabalho geral, absoluto, cheio de normas obrigatórias, de ordem pública, deve ser substituído pelo direito particular, diversificado, evolutivo, negociado", porquanto, na sociedade moderna, os valores constantes da CLT “perderam substância abrindo caminho à institucionalização de novos processos para a composição dos interesses coletivos do empresariado e dos trabalhadores numa reviravolta que lembra a passagem do status para o contractus". 574

\footnotetext{
${ }^{571}$ Martins Filho, Ives Gandra da Silva. O bélico e o lúdico no direito e no processo... Op. Cit., pp. 29-30.

572 Por óbvio, há inúmeros opositores à atribuição de maiores poderes ao sindicato na negociação das condições de trabalho consagradas por lei. A defesa de tais autores repousa em argumentos comuns: a ineficiência dos sindicatos brasileiros na real defesa dos interesses dos trabalhadores (PEREIRA, João Batista Brito. Notas sobre a flexibilização do Direito do Trabalho. In Revista do Tribunal Superior do Trabalho (TST), Brasília, vol. 68, $n^{\circ}$ 2, abr/jun de 2002); a impossibilidade de se aplicarem exemplos europeus a realidade tão distinta, como a brasileira (PEREIRA, José Luciano de Castilho. O sindicato e sua força na negociação coletiva. In Revista do Tribunal Superior do Trabalho, Brasília, vol. 67, nº 94, out/dez de 2001); a precarização do trabalho pela via da negociação coletiva (VARGAS, Luiz Alberto de et al. Setenta anos da CLT: a atualidade do direito social no século XXI. In Revista do Tribunal Superior do Trabalho, Brasília, vol. 79, no 2, abr/jun de 2013); a impossibilidade de se fazer o Direito do Trabalho atuar exclusivamente em prol de direitos econômicos (MENEZES, Cláudio Armando Couce de. O negociado sobre o legislado. In Revista do Tribunal Superior do Trabalho (TST), Brasília, vol. 68, nº 2, abr/jun 2002), entre outros. Referidos argumentos serão analisados no próximo capítulo deste trabalho.

${ }^{573}$ Como bem ressalta Cássio Mesquita Barros, "a flexibilidade econômica e social parece ser a mais importante das questões econômicas. No conjunto das formas institucionais e jurídicas relativas às relações de trabalho a possiblidade das empresas se adaptarem às imposições de ordem econômica é o meio de lutar contra os sistemas rígidos que geram custos insuportáveis na competição internacional" (BARROS, Cássio Mesquita. Modernização da CLT à luz da realidade brasileira... Op. Cit., p. 104).

${ }^{574}$ BARros, Cássio Mesquita. Modernização da CLT à luz da realidade brasileira... Op. Cit., p. 105.
} 


\subsection{A flexibilização de direitos na legislação brasileira}

A flexibilização de direitos sociais não é fenômeno recente no Direito do Trabalho brasileiro. Quer operada pelo legislador, quer pela negociação coletiva, ela é inerente ao próprio surgimento da legislação protetora, e ocorre, sobretudo, quando se intensificam as pressões do empresariado contra a rigidez dessa legislação.

Conforme salientado em outra ocasião ${ }^{575}$, qualquer valoração a priori da flexibilização evidencia posição ideológica, não condizente com estudo acadêmico. Por outro lado, simplesmente negar sua existência é ignorar a realidade das relações laborais dos séculos XX e XXI, marcada pela constante mutação dos mercados, inserção de tecnologias e surgimento de novas classes laborais - fatores que, naturalmente, levam à adaptação da legislação consolidada.

Por isso, é necessário avaliar os impactos (sociais, econômicos e políticos) da flexibilização antes de emitir qualquer juízo valorativo sobre ela - tarefa que, como bem ressalta Amauri Mascaro Nascimento, mostra-se sobremaneira árdua, mas que pode ser realizada a partir da análise de todos os momentos flexibilizadores da legislação brasileira. $^{576}$

Assim, o primeiro momento de flexibilização do Direito do Trabalho, no Brasil, ocorre já em 1965, com a promulgação, em 23 de dezembro, da Lei $n^{\circ} 4.923$ - a qual, como se sabe, permitiu a redução negociada de salários, com diminuição proporcional da jornada, diante de crises econômicas. Veja-se que referida flexibilização combina a atuação legislativa com a sindical: embora a lei permita a redução salarial, esta obrigatoriamente deve obter a chancela do sindicato para sua validade.

Maior impacto na proteção social, entretanto, foi causado pela Lei $\mathrm{n}^{\mathrm{o}}$ 5.107, de 13 de setembro de 1966, que instituiu o sistema do Fundo de Garantia do Tempo de Serviço (FGTS). Com efeito, referida lei veio atender aos suplícios patronais contra o regime da estabilidade decenal - o qual, consagrado no Brasil desde 1923 e absorvido pelo art. 492 da CLT, sofria severas críticas em virtude de, supostamente, engessar o quadro de

\footnotetext{
${ }^{575}$ Cf. capítulo 4, item 4.1 .

${ }^{576}$ Nascimento, Amauri Mascaro. Compêndio de Direito Sindical... Op. Cit., p. 410.
} 
pessoal da empresa e ocasionar "acomodação" dos empregados com mais de dez anos de casa. $^{577}$

A modificação do modelo de estabilidade foi, inadvertidamente, imposta de cima para baixo: o legislador, de forma unilateral, sem qualquer consulta prévia às partes sociais, substitui garantia jurídica por mera estabilidade econômica, cedendo aos anseios empresariais, em detrimento dos interesses reais dos trabalhadores. Não por outra razão, aliás, Alice Monteiro de Barros refere-se a aludida lei como o primeiro momento histórico de efetiva flexibilização da legislação trabalhista brasileira. ${ }^{578}$

Sabe-se que, teoricamente, o regime do FGTS apresentou-se como "alternativa" ao trabalhador: este, no momento de sua admissão na empresa, poderia optar pela estabilidade decenal ou pelo FGTS. Entretanto, sabe-se, também, que essa alternativa mostrou-se, desde o início, falaciosa, na medida em que as empresas impunham a adesão ao FGTS como condição à própria contratação - até que, em 1988, com a Constituição Federal, o sistema do Fundo de Garantia tornar-se-ia obrigatório.

Logo depois, em 1967, o Decreto-Lei $n^{\circ}$ 229, de 28 de fevereiro, altera a CLT para reconhecer a possibilidade de celebração de acordos coletivos por empresa, bem como prever a necessidade de simples depósito dos acordos e convenções coletivas de trabalho no Ministério do Trabalho (e não mais homologação, como na legislação anterior). Mais uma vez, combina-se flexibilização pela via legal com a negocial, uma vez que referidos acordos destinam-se a adaptar a legislação trabalhista à realidade concreta da prestação de serviços (embora ainda dominante o princípio da norma mais favorável, conforme redação do art. 620 da CLT, também inserido por aludido Decreto-Lei).

Em seguida, a Lei no 6.019, de 3 de janeiro de 1974, é responsável pela criação do contrato de trabalho temporário, com manifesta redução de encargos para a empresa e, em 1977, o Decreto-Lei n ${ }^{\circ} 1.535$, de 15 de abril, altera a CLT para instituir o regime de férias coletivas, garantindo ao empregador a melhor utilização do tempo de trabalho, especialmente em períodos de retração econômica. Ainda, em 20 de junho de 1983, a Lei n 7.102 permite a execução de serviços de vigilância patrimonial por meio de empresa interposta, dando ensejo às primeiras terceirizações.

\footnotetext{
${ }^{577}$ Nascimento, Amauri Mascaro. Curso de Direito do Trabalho... Op. Cit., pp. 1144-1145.

${ }^{578}$ Barros, Alice Monteiro de. Curso de Direito do Trabalho... Op. Cit., p. 797.
} 
Chega-se, então, à Constituição Federal de 1988, com a qual se instaura, no Estado brasileiro, o sistema de flexibilização da legislação consolidada pela via da negociação coletiva.

Com efeito, como se sabe, a Constituição Cidadã, atendendo aos anseios dos trabalhadores à época de sua promulgação (principalmente diante das manifestações sindicais da década de 1970), consagrou extenso rol de direito sociais, tanto de natureza trabalhista (artigos $7^{\circ}$ a 11), quanto de Seguridade Social (artigos 194 a 204). ${ }^{579}$ E, nessa consagração, atribuiu elevada importância à negociação coletiva: não apenas com o reconhecimento da força vinculante dos acordos e convenções (art. $7^{\circ}$, XXVI) e da obrigatoriedade de participação do sindicato na celebração de referidos instrumentos (art. $8^{\circ}$, VI), mas também com o permissivo de flexibilização de determinados direitos constitucionais, desde que com a participação do sindicato.

Nesse sentido, especificamente em matéria de remuneração e duração do trabalho, a Constituição permitiu, à negociação coletiva: a) a redução dos salários, mesmo diante do princípio da irredutibilidade salarial (art. $\left.7^{\circ}, \mathrm{VI}\right)$; b) a ampliação da jornada em turnos ininterruptos de revezamento (art. $7^{\circ}$, XVI); e c) a modulação do trabalho extraordinário, facultando a compensação ou redução da duração normal de trabalho por meio de acordos ou convenções coletivas.

Como se vê, a Constituição reconhece maioridade do sindicato para tratar de temas tão delicados, que podem comprometer tanto os trabalhadores (e.g., no caso de redução salarial desprovida de qualquer fundamento e sem parâmetros) quanto a própria atividade empresarial (e.g., quando a redução é negada, mesmo se fazendo necessária para a manutenção da empresa). E, acrescente-se: nem a lei, nem o poder normativo da Justiça do Trabalho detêm tão elevada capacidade, reservada única e exclusivamente ao sindicato. $^{580}$

\footnotetext{
${ }^{579}$ Walküre Lopes Ribeiro da Silva, analisando o histórico de referido dispositivo, salienta que este partiu de pressões dos sindicatos dos trabalhadores aos congressistas, diante do temor das flexibilizações das condições de trabalho já experimentadas por países europeus (SILVA, Walküre Lopes Ribeiro da. Direito do trabalho brasileiro: principais aspectos de sua evolução histórica e as propostas de modernização. In Revista do Tribunal Superior do Trabalho, Brasília, vol. 69, no 2, jul/dez de 2003, p. 132).

${ }^{580}$ Cf. Pereira, José Luciano de Castilho. O sindicato e sua força na negociação coletiva... Op. Cit., p. 28. E os sindicatos brasileiros, tidos tradicionalmente por "fracos" e "inoperantes", têm demonstrado - ao contrário do que usualmente se afirma - aptidão para referidas tarefas. Veja-se, nesse sentido, que mesmo em épocas de crises econômicas severas - como a enfrentada em 2008 - as reduções salariais ainda são exceção, e normalmente vêm acompanhadas de contrapartidas exigidas pelo sindicato (como, e.g., estabilidade pelo período da redução). De outra parte, as convenções e os acordos que flexibilizam jornada o fazem de forma temperada, sempre compatibilizando os interesses do trabalhador e das empresas.
} 
É nítida, portanto, a posição adotada pelo constituinte: flexibilizar sim, mas sempre com a consulta e ratificação das próprias partes sociais, na medida em que reais conhecedoras de seus interesses. ${ }^{581}$

Referida posição seria adotada, posteriormente, por diversos instrumentos legais tendentes à flexibilização da normativa trabalhista. Assim, e.g., a Lei $\mathrm{n}^{\circ}$ 9.601, de 21 de janeiro de 1998, que permite aos interlocutores sociais a previsão de hipóteses de celebração de contratos a prazo, com redução de encargos, além daquelas previstas na CLT; a Lei no 8.880, de 27 de maio de 1994, responsável pela desindexação de salários, atribuindo às partes a iniciativa de seu reajuste anual (medida que se mostrou essencial para o combate da inflação, embora questionada, à época, pelos sindicatos); a Medida Provisória ${ }^{\circ}$ 1.982-77, de 23 de novembro de 2000 (posteriormente convertida na Lei 10.101, de 19 de dezembro de 2000), que conferiu a possibilidade de as partes negociarem, sempre com a atuação sindical, participação nos lucros ou resultados sem natureza salarial; a Medida Provisória $\mathrm{n}^{\mathrm{o}}$ 2.164-41, de 24 de agosto de 2001, a qual, inserindo o art. 476-A à CLT, instituiu a possibilidade de suspensão temporária do contrato de trabalho para qualificação profissional, mediante acordo com o sindicato (utilizada pelas empresas sobretudo em épocas de crise econômica); a Lei $\mathrm{n}^{\circ}$ 9.957, de 12 de janeiro de 2000, responsável pela criação das Comissões de Conciliação Prévia no âmbito dos sindicatos; a Lei Complementar 123, de 2006, que atribuiu ao sindicato a possibilidade de estimar as horas in itinere para as micro e pequenas empresas; entre outros. Isso tudo sem falar na infinidade de Súmulas e Orientações Jurisprudenciais do TST que conferiram amplo poder de negociação ao sindicato - as quais serão analisadas com mais vagar a seguir. ${ }^{582}$

Porém, a flexibilização da legislação trabalhista não se operou, exclusivamente, pela via do fortalecimento do poder negocial das partes: inúmeras foram, com efeito, as medidas impostas unilateralmente pelo legislador ou, até mesmo, pela jurisprudência - muitas das quais se mostram de duvidosa constitucionalidade, diante da especificação constitucional da flexibilização exclusiva pela via negocial.

Entre tais medidas, destacam-se: a) a revogação, em 1989 (Lei nº 7.855), de diversas proibições ao trabalho da mulher ${ }^{583}$; b) o permissivo à terceirização, em 1993,

\footnotetext{
${ }^{581}$ A respeito, cf. SILva, Walküre Lopes Ribeiro da. Autonomia Privada Coletiva... Op. Cit., p. 149. ${ }^{582}$ Cf. infra, capítulo 6, item 6.3.1.

${ }^{583}$ A qual não pode ser criticada, pois fundada no próprio art. $5^{\circ}, \mathrm{I}, \mathrm{da} \mathrm{CF} / 88$.
} 
com a revisão da Súmula 256 e publicação da Súmula 331, ambas do TST; c) descaracterização, em 1994, do vínculo de emprego entre cooperados e cooperativas, segundo o artigo 442, parágrafo único, CLT (inserido pela Lei $\mathrm{n}^{\mathrm{o}}$ 8.949/94); d) a autorização, em 1997, para terceirização de atividade-fim nos serviços de telecomunicações (Lei $n^{\circ}$ 9.472); e) a descaracterização, em 2001, da natureza salarial de diversas verbas trabalhistas, conforme redação do art. $458, \S 2^{\circ}$, CLT, conferida pela Lei $n^{\circ}$ $10.243^{584}$; f) a criação do contrato de trabalho a tempo parcial, de até 25 horas semanais, com salário proporcional (art. 58-A, CLT, inserido pela Medida Provisória $\mathrm{n}^{\circ} 2.164$ 41/01); g) a alteração operada pela Lei 11.101, de 2005, para limitar o privilégio dos créditos trabalhistas na massa falida e a sucessão de empresas em falência ou recuperação judicial (posicionamento que seria amparado pelo Supremo Tribunal Federal em 2005 ADIn 3934/DF ${ }^{585}$ ); entre outras.

Como se vê, se é certo que muitas foram as alterações efetuadas unilateralmente pelo legislador e pela jurisprudência pátria, sem consulta às partes sociais, elas ainda perdem - em número e abrangência da matéria - para aquelas que envolvem a atuação da negociação coletiva, tal como determinado pelo legislador constituinte. ${ }^{586}$

Em síntese, diante do quadro acima exposto - e com base na doutrina de Amauri Mascaro Nascimento ${ }^{587}$ - é possível apontar algumas características gerais a respeito da flexibilização em solo brasileiro, a saber:

a) Não foi obra específica de um determinado governo, mas ocorreu de modo difuso e nos mais variados momentos da história do Direito do Trabalho brasileiro. Como já dito em outra ocasião ${ }^{588}$, não se pode afirmar que a flexibilização é incompatível com governos de cunho eminentemente social: por óbvio, ela se mostra mais

\footnotetext{
${ }^{584}$ A qual também se mostrou salutar, na medida em que incentivou o fornecimento de diversas utilidades pelo empregador, antes renegadas ao empregado em virtude de seu caráter salarial.

${ }_{585}$ Aliás, nos últimos anos, sabe-se que o STF tem proferido diversas decisões de cunho manifestamente flexibilizador, sob o prisma da necessária alteração da legislação trabalhista para manutenção da atividade empresarial e geração de empregos. Assim, e.g., cite o reconhecimento, em 2011, da ausência de responsabilidade dos órgãos da Administração Pública quando da terceirização regular (ADC 16-DF/10) e, em 2014, a redução do prazo prescricional do FGTS para 5 anos (ARE 709212),

586 Aliás, ainda hoje, verifica-se grande relutância para aceitarem-se alterações na legislação trabalhista independentemente da participação dos atores sociais. Nesse sentido, citem-se, por exemplo, as discussões a respeito da regulamentação legal da terceirização - embora tramitem, no Congresso Nacional, diversos projetos nesse sentido, nenhum deles se encontra em fase avançada, justamente diante da resistência dos sindicatos para sua aprovação.

${ }^{587}$ NAscimento, Amauri Mascaro. Compêndio de Direito Sindical... Op. Cit., p. 420.

${ }^{588}$ Cf. supra, capítulo 4, item 4.1 .
} 
presente em Estados com características neoliberais, mas também ocorre (ainda que de forma tímida) em governos de orientação esquerdista;

b) Ocorreu de forma gradual, evitando grandes descontentamentos populares com sua implementação de uma só vez;

c) $\mathrm{Na}$ grande parte das alterações legais sofridas, combinou-se a atuação legislativa com a negocial para a adaptação de direitos trabalhistas consagrados, confiando-se aos sindicatos a atribuição de determinar os limites da flexibilização.

Com relação ao último aspecto, deve-se recordar o quanto já exposto acerca da necessária busca pela flexissegurança ${ }^{589}:$ mesmo em tempos de remodelação da legislação protetora aos interesses concretos dos atores sociais, é preciso sedimentar o garantismo do Direito do Trabalho, que marcou sua afirmação enquanto ciência jurídica e, até hoje, delineia os espaços de sua atuação. A diferença é que, agora, não se pugna mais por um garantismo estritamente estatal, e sim pela combinação deste com um garantismo “coletivo", marcado pela participação direta dos interessados na flexibilização das leis trabalhistas.

Para tanto, é preciso dar passo à frente: hoje, a flexibilização pela negociação coletiva é a exceção, permitida apenas quando expressamente autorizada por lei. É necessário inverter esse quadro, transformando a regulamentação pela via coletiva em regra geral e prevendo em lei, tão-somente, matérias de imperatividade absoluta, intocáveis pelas partes sociais - na linha do quanto verificado em países europeus, mas sempre considerando a realidade brasileira.

${ }^{589}$ Cf. supra, capítulo 4, item 4.3.2. 


\subsection{Alterações legislativas e propostas}

A rediscussão do diálogo das fontes do Direito do Trabalho brasileiro com intuito de fortalecimento da negociação coletiva em detrimento da lei - não é fato recente.

Com efeito, Cássio Mesquita Barros retoma experiência vivenciada pela legislação pátria já em 1931: em fevereiro desse ano, o então Ministro do Trabalho, Lindolfo Collor, apresentou ao chefe de Governo Provisório projeto sobre o direito de associação sindical e, em setembro, projeto de convenção coletiva para determinar "o montante dos salários, os seus complementos, as bases do trabalho, as divisões do tempo nos horários diurno e noturno, as condições de descanso, etc.". Justificava-se referido projeto sob o argumento de que a livre concorrência sem contrato significa a prosperidade de uns à custa do sacrifício de outros, gerando desorganização - e a convenção coletiva deveria ser, no Brasil, como já era na Europa, o instrumento mais importante para a flexibilização do Direito do Trabalho. ${ }^{590}$ Com a promulgação da CLT, o projeto seria abandonado.

É no final do século XX, entretanto, que as propostas de reforma da legislação, com a instituição do contrato coletivo em solo brasileiro, intensificam-se.

Inicialmente, deve-se destacar a Lei $\mathrm{n}^{\mathrm{o}} 8.542$, de 23 de dezembro de 1992, sobre política salarial, a qual fez referência expressa ao "contrato coletivo de trabalho" - sem, todavia, defini-lo.

Sabe-se, nesse sentido, que o modelo de relações coletivas no Brasil sempre foi exteriorizado por dois instrumentos normativos: as convenções e os acordos coletivos de trabalho. Contudo, com a supracitada lei (que seria posteriormente revogada pela Lei 10.192/01), foi introduzida no direito brasileiro a expressão "contrato coletivo de trabalho": em diversas passagens, a lei dita que as "condições de trabalho" serão regidas por "acordos, convenções e contratos coletivos de trabalho".

${ }^{590}$ BARros, Cássio Mesquita. Modernização da CLT à luz da realidade brasileira ... Op. Cit., p. 111. 
Conforme exposto em outro momento do presente estudo ${ }^{591}$, a expressão "contrato coletivo" apresenta elevada carga axiológica entre os autores brasileiros, sendo empregue para conceituar instrumento negocial com capacidade de alterar, in melius ou in peius, a legislação consolidada. ${ }^{592}$ Assim, causou furor sua utilização pela mencionada Lei $\mathrm{n}^{\mathrm{o}} 8.542 / 1992$, surgindo divergências doutrinárias a respeito de seu alcance. Tratar-se-ia de nova espécie de fonte negocial admitida pelo ordenamento? Ou, ao contrário, estaria tal expressão inserida no grande grupo das convenções coletivas de trabalho lato sensu, previstas no artigo 611 e seguintes da CLT? ${ }^{593}$

O sindicalismo, na época, dividiu-se em três teorias distintas. ${ }^{594} \mathrm{~A}$ primeira, denominada limitativa, defendia que o contrato coletivo de trabalho, previsto por referida lei, não seria um novo nível de negociação, confundindo-se com os existentes não haveria distinções, assim, entre contrato coletivo e convenções e acordos coletivos de trabalho. Contudo, para uma segunda vertente, ampliativa, o contrato coletivo corresponderia a novo nível de negociação e de legitimação para negociar - tratar-se-ia de negociação em nível superior, mais amplo do que o da categoria, podendo abranger mais de um setor econômico ou profissional. Finalmente, a terceira teoria, reformista, enxergou no contrato coletivo a prova da superação do corporativismo e da valorização da autonomia coletiva, com maior espaço para a atuação direta dos interlocutores sociais - ou seja, com a carga valorativa que a expressão encontra na doutrina brasileira nos dias atuais.

Independentemente da teoria adotada, porém, Amauri Mascaro Nascimento explica que o contrato coletivo previsto na Lei $\mathrm{n}^{\circ} 8.542 / 92$ nunca chegou a ser utilizado na prática - e, agora, encontra-se expressamente revogado. ${ }^{595}$ Tal situação leva o

\footnotetext{
${ }^{591}$ Cf. supra, capítulo 2, item 2.4.1.

592 Cf., entre outros, Nascimento, Amauri Mascaro. Curso de Direito do Trabalho... Op. Cit., p. 1389; Delgado, Mauricio Godinho. Curso de Direito do Trabalho... Op. Cit., p. 162; Mannrich, Nelson. Empregabilidade, ocupação e novas formas de trabalho. In Revista da Faculdade de Direito da Universidade de São Paulo, v. 100, jan/dez de 2005, p. 114; PEREIRA, João Batista Brito. Notas sobre a flexibilização do Direito do Trabalho... Op. Cit., p. 46.

${ }_{593}$ Em realidade, conforme expõe Dóris Krause Killian, a expressão já tinha sido consagrada pela doutrina em fevereiro de 1988, quando o Departamento Metalúrgico Estadual da CUT (Central Única dos Trabalhadores) apresentou à FIESP (Federação das Indústrias do Estado de São Paulo) pauta de reivindicações na qual defendia a negociação por níveis e conforme as especificidades de cada setor econômico (KILIAN, Dóris Krause. Negociação coletiva de trabalho. Porto Alegre: EDIPUCRS, 2003, pp. 88-89).

${ }^{594}$ A análise de referidas divergências será efetuada com base nas obras de Amauri Mascaro Nascimento (Nascimento, Amauri Mascaro. Compêndio de Direito Sindical... Op. Cit., pp. 527-528) e de Evaristo de Moraes Filho e Antonio Carlos Flores de Moraes (MorAEs Filho, Evaristo de; e, MoraES, Antonio Carlos Flores de. Introdução ao Direito do Trabalho. 10 Ed.. São Paulo: LTr, 2010, p. 719), os quais apresentam síntese dos posicionamentos surgidos à época da alteração legislativa

${ }^{595}$ Antes mesmo de sua revogação definitiva, aliás, o contrato coletivo encontrou diversos percalços formais durante a vigência da Lei $n^{\circ} 8.542 / 92$ : os $\S \S 1^{\circ}$ e $2^{\circ}$ do art. $1^{\circ}$ de referido diploma, que consagravam tal
} 
autor a afirmar que, por conseguinte, o contrato coletivo permanece como uma pretensão e não uma realidade vigente no ordenamento brasileiro. 596597

De qualquer maneira, a corroborar a tese de que a Lei $\mathrm{n}^{\circ} 8.542 / 92$ efetivamente pretendia operar reforma no diálogo das fontes trabalhistas, em 1993, seria apresentado, ao então Ministro do Trabalho Walter Barelli, o "Anteprojeto de Lei das Relações Coletivas de Trabalho". Elaborado por comissão de juristas presidida por João de Lima Teixeira Filho ${ }^{598}$, aludido projeto previa o contrato coletivo de trabalho como resultante de negociação coletiva de âmbito nacional, em um ou mais setores econômicos, legitimando a celebrá-lo as Centrais Sindicais, as Confederações e as Federações nacionais. $^{599}$

Com efeito, a Exposição de Motivos de referido projeto assim explicitava:

\begin{abstract}
"São mantidos dois níveis conhecidos de negociação, o de empresa e o de categoria. No entanto, é criado mais um nível, com o que os instrumentos normativos de autocomposição passam a ser três: o acordo coletivo, aplicável aos trabalhadores da empresa ou empresas; a convenção coletiva de trabalho, que é o vínculo intersindical de categoria econômica e profissional; e, como
\end{abstract}

contrato, foram revogados pelo art. 19 da MP 1.675-42, de 25.09.1998. Porém, aludido artigo da medida provisória teve sua eficácia suspensa por decisão liminar, que não foi confirmada posteriormente. De qualquer maneira, em 2001, esses parágrafos foram revogados formalmente.

${ }_{596}$ Nascimento, Amauri Mascaro. Compêndio de Direito Sindical... Op. Cit., pp. 528.

597 Importante ressaltar, de qualquer maneira, que a expressão ainda é utilizada por alguns instrumentos legislativos. Assim, e.g., a Lei $\mathrm{n}^{\circ}$ 8630/90, que previu, para o trabalho portuário, a existência de "contratos, acordos e convenções coletivas de trabalho", expressões que vêm repetidas na Lei 12.815/13, mais uma vez sem qualquer definição precisa. No mesmo sentido, a própria CLT, em diversos artigos, utiliza-se de referida expressão, entre os quais se destacam os de $n^{\circ}$ 59, 61, 71, 295 e 462. Ademais, a epígrafe do Título VI de referida Consolidação era, justamente, "Do contrato coletivo de trabalho" - em manifesta influência da Carta Constitucional de 1937, a qual, em seu artigo 137, falava de "contratos coletivos de trabalho" (essa epígrafe, porém, seria substituída, com o Decreto-lei 229/1967, por "Convenções Coletivas de Trabalho" - termo utilizado nas Constituições brasileiras a partir de 1946). Todavia, entende-se que as menções ao contrato coletivo na CLT e na legislação extravagante, atualmente, correspondem a meros equívocos do legislador, o qual demonstrou falta de cuidado ao empregar a expressão como sinônimo de acordos e convenções coletivas de trabalho (ou, no caso dos dispositivos da CLT, de puro esquecimento: por ocasião da reforma de 1967, não se lembrou de alterar a redação dos artigos que mencionavam tais espécies negociais).

598 Denominada "Comissão de Modernização da Legislação do Trabalho", que também contava com a participação de Almir Pazzianotto Pinto, Amauri Mascaro Nascimento, Cássio de Mesquita Barros Júnior, Arnaldo Lopes Süssekind e Arion Sayão Romita.

${ }_{599}$ Para mais informações sobre o Anteprojeto, cf. SILVA, Walküre Lopes Ribeiro da. Direito do trabalho brasileiro: principais aspectos de sua evolução histórica e as propostas de modernização... Op. Cit., p. 135; KILIAN, Dóris Krause. Negociação coletiva de trabalho... Op. Cit., p. 90 e ss; e TEIXEIRA FILHO, João de Lima. Uma proposta de reforma da legislação do trabalho. In Revista do Ministério Público do Trabalho, Brasília, nº $06-2^{\circ}$ semestre - setembro de 1993. 
inovação, o contrato coletivo de trabalho, que estabeleceria as normas gerais aplicáveis aos acordos e convenções". ${ }^{600}$

Com a instituição do contrato coletivo de trabalho, a Comissão propôs verdadeira revolução no diálogo das fontes trabalhistas: atribuiu-se à negociação coletiva ampla capacidade de regulamentar as condições de trabalho, cabendo à lei apenas atuar de forma supletiva, quando inexistente consenso entre as partes. ${ }^{601} \mathrm{E}$ esta - a lei - seria vista simplesmente "como uma rede de proteção mínima para o trabalhador, na ausência de estipulação negociada". ${ }^{602}$

Nesse sentido, juntamente com o Anteprojeto de Relações Coletivas do Trabalho, foi apresentado, pela Comissão, Anteprojeto de Relações Individuais do Trabalho, do qual constavam normas de proteção mínima ao trabalhador. Entretanto, ressaltou-se, diversas vezes, no relatório apresentado, que essas normas de direito individual somente seriam aplicáveis na ausência de estipulação pelas partes coletivas. ${ }^{603}$ Assim, o acordo, a convenção ou o contrato coletivo prevaleceriam sobre a lei naquilo que estipulassem de modo distinto - apenas se afastando referida regra diante de norma de ordem pública e, portanto, imperativa.

No contexto da reforma, o contrato coletivo de trabalho seria o instrumento normativo de abrangência mais ampla (nacional), responsável pela positivação de "normas gerais e condições de trabalho a serem observadas como parâmetros nas negociações que se realizarem em outros níveis, nas bases territoriais das suas respectivas representações". ${ }^{604} 605$ Porém, ciente da necessidade de adaptação da normativa a casos

\footnotetext{
${ }^{600}$ Texto integral do Anteprojeto disponível online em http://www.jusbrasil.com.br/diarios/955754/pg-69secao-1-diario-oficial-da-uniao-dou-de-20-01-1993.

${ }^{601}$ Em sentido contrário, o entendimento de Evaristo de Moraes Filho e Antonio Carlos Flores de Moraes, para quem o Anteprojeto, ao consagrar o contrato coletivo, "nada cria de novo em nosso ordenamento jurídico, uma vez que já se acha prevista na atual Consolidação ( $\$ 2^{\circ}$ do art. 611 a possibilidade de ser firmada uma convenção coletiva de caráter nacional" (MORAES FILHO, Evaristo de; e, MoRAES, Antonio Carlos Flores de. Introdução ao Direito do Trabalho... Op. Cit., p. 719).

${ }^{602}$ TeIXEIRA FILHO, João de Lima. Uma proposta de reforma da legislação do trabalho... Op. Cit., p. 16.

${ }^{603}$ Veja-se, a respeito, o art. $1^{\circ}$ da Lei de Relações Individuais do Trabalho, o qual dispunha que "a presente lei disciplina as relações individuais de trabalho urbano, rural e avulso, na ausência de instrumento normativo que disponha de modo diverso, ressalvadas as garantias constitucionais".

${ }^{604}$ Consoante art. 19 da Lei de Relações Coletivas de Trabalho.

${ }^{605}$ Nas teorias acima explicitadas, corresponderia ao contrato defendido pela teoria ampliativa - de maior abrangência, podendo ser negociado, até mesmo, por mais de uma categoria. Referida teoria é adotada, por exemplo, por Carlos Henrique Bezerra Leite, para quem o contrato coletivo corresponderia a "negociação de âmbito nacional e supracategorial que visa estabelecer regras básicas para os demais instrumentos coletivos" e seria negociado pelas centrais sindicais (LeITE, Carlos Henrique Bezerra. Curso de Direito do Trabalho. 5 Ed.. São Paulo: Saraiva, 2014, p. 618).
} 
individualizados e menos abrangentes, a Exposição de Motivos do Anteprojeto ressaltava que:

\begin{abstract}
"O anteprojeto propõe-se evitar que o contrato coletivo de trabalho asfixie a atividade negocial a ser desenvolvida pelos sindicatos ante a realidade específica em que estão inseridos. O contrato coletivo não consiste, portanto, na contratação articulada, em que o instrumento mais abrangente contém progressivamente o mais restrito. O anteprojeto contempla a realidade brasileira que demonstra haver um incremento de acordos coletivos e uma redução de convenções coletivas. Por isto, e objetivando não frustrar a negociação onde os interesses mais específicos são sintonizados, é dada prioridade ao acordo coletivo sobre a convenção, quando concomitantemente aplicáveis. Para evitar que a empresa possa impor normas e condições de trabalho contrárias à proteção mínima dispensada aos trabalhadores no contrato coletivo, principalmente àqueles que são representados por sindicatos sem maior poder de pressão, são previstos parâmetros obrigatórios às convenções e acordos coletivos. Conjuga-se, assim, o entendimento entre as lideranças. nacionais de trabalhadores e empregadores, que devem expressar um razoável equilíbrio entre as necessidades do assalariado, as possibilidades do segmento patronal e os interesses bem comum com a facetada realidade em que empregados e empregadores convivem nos mais distintos rincões deste pais de tantas desigualdades regionais". (grifou-se)
\end{abstract}

Com efeito, no art. 22 da Lei de Relações Coletivas de Trabalho, especificava-se que "o acordo coletivo prevalecerá sobre a convenção coletiva quando concomitantemente aplicável às mesmas partes". ${ }^{606}$

Entretanto, longe de apenas propor a reforma da interação das fontes trabalhistas, a Comissão pugnava por profunda reforma sindical, com a instituição do pluralismo no país e a plena liberdade de escolha do sindicato a que o trabalhador irá associar-se. O Anteprojeto, com efeito, defendia a extinção da contribuição sindical obrigatória, substituindo-a por contribuições negociadas; a definição do sindicato como pessoa jurídica de direito privado; a proibição expressa às condutas anti-sindicais; e o

\footnotetext{
${ }^{606}$ Entretanto, manteve-se a previsão no sentido de que o contrato individual de trabalho não poderia contrariar normas advindas da negociação coletiva, conforme art. 23 da Lei - o qual, também em manifesta inovação do tema, permitiu a alteração pelo contrato individual de normas no caso de "cargo de hierarquia superior, e àquele para cujo exercício seja exigida excepcional qualificação tecnológica". Ademais, no que tange à regulamentação de profissões específicas, esta foi atribuída integralmente a convenções coletivas de abrangência nacional - evitando, dessa forma, que profissões com maior "influência" no Congresso Nacional fossem beneficiadas em detrimento de outras.
} 
reconhecimento das centrais sindicais enquanto legítimas detentoras de capacidade negocial.

Justificando a opção do Anteprojeto pelo sistema autônomo de regulamentação das condições de trabalho, João de Lima Teixeira Filho afirma que "essa proposta (...) guarda sintonia com as desigualdades regionais deste país-continente, que convive com regiões em distinto estágio de desenvolvimento socioeconômico" e de "amadurecimento do movimento sindical e da correspondente prática da negociação coletiva". 607

Após sua publicação no Diário Oficial da União, o Anteprojeto seria aproveitado pelo Deputado Carlos Alberto Campista (PDT/RJ) para apresentação dos Projetos de Lei $n^{o} 3.747$ e 3.748, ambos de 29 de junho de 1993. Entretanto, depois de breve tramitação na Câmara dos Deputados, ambos os projetos acabaram arquivados em 1995.

O debate acerca da necessária revisão do sistema de fontes trabalhistas seria retomado, ainda em 1993, no Fórum Nacional sobre Contrato Coletivo e Relações de Trabalho, realizado na cidade do Rio de Janeiro, de 22 de setembro a 10 de dezembro desse ano. Como resultado dos debates ocorridos em aludido Fórum, os representantes de trabalhadores, empregadores e Estado divulgaram documento contendo as principais mudanças a serem operadas na legislação brasileira - das quais, destacavam-se a "necessidade da negociação entre as partes sem a interferência compulsória de terceiros, inclusive no setor público" e a "necessidade de espaços para o exercício da negociação de formas alternativas e aplicação das normas sem a desregulamentação do Direito". ${ }^{608}$

Logo em sequência, em 1994, seria apresentado por Hugo Gueiros Bernardes o Projeto de Lei $n^{\circ} 4.864$, de cuja elaboração participara Octavio Bueno Magano. O projeto atribuiu à negociação coletiva ampla possibilidade de alteração da legislação aplicável, com exceção de um núcleo duro de regras. Porém, especificou que, na

${ }^{607}$ TeIXEIRA FILHO, João de Lima. Uma proposta de reforma da legislação do trabalho... Op. Cit., p. 16. Porém, continua o autor, "há quem relegue a entidade de classe a um plano de incapacidade relativa: haveria contratação in pejus... Este enfoque se explica como resultante de visão impregnada pela velha ordem sindical Mussoliniana, que se mostrou absolutamente sofrível na representatividade dos trabalhadores, e também pela noção sociológica de resistência à mudança, que desdenha do cenário de liberdade sindical, onde a concorrência para bem representar interesses profissionais sepulta entidades cartoriais travestidas de sindicatos".

${ }^{608}$ Texto integral disponível em CAMARGos, Regina Coeli Moreira. O movimento sindical diante da reforma das suas instituições: visões e contradições. In Revista ABET, vol. IX, n. 2/2010. 
adaptação da normativa legal, sempre deveria ser aplicado o critério do conglobamento, ou seja, o conjunto normativo negociado jamais poderia ser menos favorável ao trabalhador.

O projeto, todavia, tampouco logrou êxito no Congresso Nacional, sendo arquivado em 13 de abril de 1998.

Em 4 de outubro de 2001, no final do governo de Fernando Henrique Cardoso, foi apresentado pelo Poder Executivo à Câmara dos Deputados o Projeto de Lei $\mathrm{n}^{\mathrm{o}}$ 5.483/01, tendente a alterar o art. 618 da CLT para estabelecer que "as condições de trabalho ajustadas mediante convenção ou acordo coletivo prevalecem sobre o disposto em lei, desde que não contrariem a Constituição Federal e as normas de segurança e saúde do trabalho". 609

Na justificativa do Projeto, o Ministério do Trabalho - representado pelo então Ministro Francisco Dornelles - ressaltou a necessidade de "prestigiar a negociação coletiva sem agredir direitos e garantias constitucionais", já que "a economia (...) pede direitos negociáveis e contratualizados" e "a demora de um processo amplo de modificação do texto consolidado não acompanha a celeridade das mudanças requeridas pela sociedade". 610

Referido Projeto de Lei, após emendas, foi aprovado pela Câmara dos Deputados, em 04 de dezembro de 2001, atribuindo-se a seguinte redação ao art. 618, da CLT:

Art. 618 da CLT: Na ausência de convenção ou acordo coletivo firmados por manifestação expressa da vontade das partes e observadas as demais disposições do Titulo VI desta Consolidação, a lei regulará as condições de trabalho.

$\S 1^{\mathrm{o}}$ A convenção ou acordo coletivo, respeitados os direitos trabalhistas previstos na Constituição Federal, não podem contrariar lei complementar, as Leis $\mathrm{n}^{\mathbf{0}}$ 6.321, de 14 de abril de 1976, e $\mathrm{n}^{\mathrm{o}} 7.418$, de 16 de dezembro de 1995, a legislação tributária, a previdenciária e a relativa ao Fundo de Garantia do

\footnotetext{
${ }^{609}$ Segundo leciona Amauri Mascaro Nascimento, a proposta inicial era promover-se alteração no art. 468, da CLT, mas "redefinições do projeto acabaram por propor a introdução das modificações no art. 618", já que "este texto é mais amplo, uma vez que está incluído entre as leis sobre negociação coletiva e não sobre contrato individual de trabalho". (NASCIMENTO, Amauri Mascaro. Limites da negociação coletiva na perspectiva de projeto de flexibilização da CLT... Op. Cit., p. 1421). No mesmo sentido, o posicionamento de João Batista Brito Pereira, para quem o Projeto $n^{\circ}$ 5.483/01 tinha como alvo, na verdade, a alteração do art. 468 da CLT, já que qualquer proposta de flexibilização das normas trabalhistas depende da inserção, no art. 468, de parágrafo que autorize a convenção coletiva a alterar a legislação vigente (PEREIRA, João Batista Brito. Notas sobre a flexibilização do Direito do Trabalho... Op. Cit., p. 46)

610 Texto integral $\quad$ disponível online
} http://imagem.camara.gov.br/Imagem/d/pdf/DCD05OUT2001.pdf\#page=28. 
Tempo de Serviço - FGTS, bem como as normas de segurança e saúde do trabalho.

$\S 2^{\circ}$ Os sindicatos poderão solicitar o apoio e o acompanhamento da central sindical, da confederação ou federação a que estiverem filiados quando da negociação de convenção ou acordo coletivo previstos no presente artigo.

Veja-se que o Projeto $\mathrm{n}^{\circ}$ 5.843/01 repetiu a experiência já consagrada no Anteprojeto de Relações Coletivas de Trabalho, apresentado em 1993: atribuiu à legislação estatal caráter meramente supletivo em relação à negociação coletiva, apenas sendo aquela invocada quando inconciliáveis as partes sociais. E, ainda, manteve a previsão da inalterabilidade de normas de ordem pública, na linha do quanto já proposto em 1993.

Porém, em virtude dos diversos substitutivos apresentados, houve considerável ampliação das normas que não poderiam ser objeto da negociação coletiva: a Constituição Federal e a legislação de saúde e segurança no trabalho já constavam do Projeto original; após a passagem pela Câmara, inserem-se como regras de ordem pública as leis complementares, a Lei $\mathrm{n}^{\circ}$ 6.321/76 (sobre Programa de Alimentação do Trabalhador), a Lei $\mathrm{n}^{\circ}$ 7.418/85 (sobre vale-transporte), as legislações tributária, previdenciária e a relativa ao FGTS.

Verificou-se, em referido Projeto, nítida intenção de fortalecimento da negociação coletiva, interpretada como única "forma possível, no momento, para a preservação ou a criação de empregos" ${ }^{\prime 611}$, mediante o reconhecimento de maturidade ao sindicato. O Ministro Francisco Dornelles, por ocasião da apresentação do Projeto, afirmou que os sindicatos, mesmo os fracos e sem grande capacidade negocial, poderiam negar a contratação coletiva, recusando-se a sentar na mesa de negociação se a alteração legislativa não se lhes mostrasse favorável. ${ }^{612} \mathrm{O}$ Projeto, portanto, acabaria, em última análise, fortalecendo as organizações sindicais brasileiras. ${ }^{613}$

\footnotetext{
611 NASCimento, Amauri Mascaro. Limites da negociação coletiva na perspectiva de projeto de flexibilização da CLT... Op. Cit., p. 1419.

${ }^{612}$ Entrevista concedida ao jornal Folha de São Paulo, edição de 26 de novembro de 2001 ("Para Dornelles, 'nova CLT' fortalecerá os sindicatos').

${ }^{613}$ Em sentido contrário, manifestou-se Luiz Marinho - à época, Presidente do Sindicato dos Metalúrgicos do $\mathrm{ABC}$ - ao afirmar que os sindicatos brasileiros não estavam preparados para enfrentar a livre negociação com as empresas e discutir a flexibilização de direitos trabalhistas (Entrevista concedida ao jornal Folha de São Paulo, edição de 28 de novembro de 2001 - "Muitos sindicatos vão quebrar, diz Marinho").
} 
A proposta de alteração da CLT foi extremamente criticada, sobretudo pela mídia, e causou furor entre sindicalistas e trabalhadores. ${ }^{614} \mathrm{Em}$ posicionamento puramente ideológico, profetizou-se uma suposta desregulamentação dos direitos trabalhistas, simples precarização sem qualquer contrapartida ao empregado. Afirmou-se que atribuir tamanho poder ao sindicato - tradicionalmente visto como o grande vilão das relações trabalhistas, dada sua falta de representatividade - seria pura irresponsabilidade, e geraria simples aniquilação de direitos. ${ }^{615}$

Questionaram-se, ainda, os motivos que ensejaram a apresentação de referido projeto: o então Ministro do TST, João Batista Brito Pereira, por exemplo, afirmou que "causa preocupação o esforço para que o acordo coletivo de trabalho e a convenção coletiva de trabalho prevaleçam sobre a lei, na medida em que fica sem explicação a razão pela qual a ideia floresceu". ${ }^{616}$ Ademais, criticou-se o fato de que a alteração teria sido imposta de cima para baixo, sem qualquer negociação com as partes interessadas. ${ }^{617}$

Também se apontou suposta inconstitucionalidade do aludido Projeto de Lei, sob o argumento de que apenas a Constituição da República está apta a autorizar a negociação in peius (como o faz no art. $7^{\circ}$, incisos VI, XIII e XIV). Portanto, somente poderia prevalecer o negociado sobre o legislado nos temas previstos constitucionalmente, quais sejam, redução de salários e jornada.

\footnotetext{
${ }^{614}$ Conforme bem ressalta Ives Gandra da Silva Martins Filho, "a resistência de parlamentares e sindicalistas à prevalência do negociado sobre o legislado foi de tal ordem, que muitos distúrbios se verificaram, quer dentro do Congresso Nacional, quer nas ruas, com passeatas em defesa da CLT em sua integralidade" (Martins Filho, Ives Gandra da Silva. Valorização da negociação coletiva e flexibilização das normas legais trabalhistas. In Revista Jurídica, Brasília, v. 8, n. 79, jun./jul., 2006, p. 3). Com efeito, o próprio debate do projeto no Congresso Nacional foi marcado por invasão de sindicalistas, quebra de portas, falha do painel eletrônico do Plenário da Câmara na primeira votação, manifestações contrárias de trabalhadores, etc.

${ }^{615}$ Para referidas críticas, cf., e.g., MENEZES, Cláudio Armando Couce de. O negociado sobre o legislado... Op. Cit.. No mesmo sentido, cf. SüSSEKIND, Arnaldo. Flexibilização da legislação trabalhista. In Folha de São Paulo, São Paulo, edição de 27 de novembro de 2001, Tendências/Debates.

${ }^{616}$ PereIRA, João Batista Brito. Notas sobre a flexibilização do Direito do Trabalho... Op. Cit., p. 41. Em crítica bastante ferrenha à proposta de alteração, o autor afirma que "não é exagero supor, para citar apenas dois exemplos, que o $13^{\circ}$ salário possa ser fracionado em 12 parcelas, e as férias sejam substituídas por uma remuneração, ficando o empregado sem a reposição anual de suas energias. E, ainda, que o adicional noturno e a hora noturna sofram modificação para pior, e a licença-maternidade seja fracionada ao longo do ano. Quem defenderá esses dois títulos como normas de higiene e saúde do trabalho?” (PEREIRA, João Batista Brito. Notas sobre a flexibilização do Direito do Trabalho... Op. Cit.., p. 42). Em sentido análogo, entende João Antonio Felício que "por causa da fragilidade da grande maioria dos sindicatos (...), as empresas conseguirão impor acordos para pagar o $13^{\circ}$ salário em várias vezes, parcelar o pagamento de férias e poderão distribuir ao longo do ano o gozo dos 30 dias de férias, do descanso semanal remunerado e das licenças maternidade e paternidade" (FELICIO, João Antonio. A flexibilização da CLT a ser votada no Senado beneficia o trabalhador? NÃO - Um projeto que retira direitos. In Folha de São Paulo, São Paulo, edição de 29 de dezembro de 2001).

${ }^{617}$ Cf. FELICIO, João Antonio. A flexibilização da CLT a ser votada no Senado beneficia o trabalhador?... Op. Cit..
} 
Cláudio Armando Couce de Menezes, por exemplo, sustenta que não se pode utilizar a previsão do art. $7^{\circ}, \mathrm{XXVI}, \mathrm{CF} / 88$ para justificar qualquer tipo de flexibilização além daquelas já autorizadas pela própria Constituição. Em seu entender, a regra constitucional só reafirmou o que já vinha disposto no art. 611 da CLT - o qual jamais autorizou a supressão ou redução de qualquer direito trabalhista. Ademais, é necessário efetuar interpretação lógico-sistemática do dispositivo com os anteriormente citados: quando a Constituição desejou permitir a negociação in peius, já especificou as hipóteses de seu cabimento. Finalmente, salienta o autor que, se o inciso XXVI, do art. $7^{\circ}$, autorizasse derrogação pura e simples de direitos pela negociação coletiva, "não teria procurado o governo, através de projeto de Emenda Constitucional, inserir na Carta Magna a ampla supressão ou redução dos direitos dos trabalhadores". 618

Quanto a tais críticas, bem se posicionou, à época, Amauri Mascaro Nascimento, ao salientar que referido projeto apenas demonstrava a continuidade de uma postura já adotada desde 1988, "e não a decapitação da CLT, como exageradamente se afirma", pois, se assim fosse, a luta travada contra o projeto teria que ser voltada também para o art. $7^{\circ}$, VI, da CF/88 - o qual, como se viu, permite a redução de salário de salários mediante negociação coletiva, "sobrepondo, em matéria salarial, o negociado sobre o legislado". 619

De outra parte, sobre a acusação de suposta inconstitucionalidade do Projeto, o mesmo autor apresenta três argumentos aptos a rechaçá-la: em primeiro lugar, o próprio Projeto assegura a manutenção dos direitos constitucionais, vedando a negociação in peius com relação àqueles; em segundo, a autorização constitucional para a validade da negociação coletiva não se reduz a um tema específico, mas é genérica, conforme se infere do art. $7^{\circ}$, inciso XXVI; em terceiro, se a própria Constituição autoriza a negociação in peius, referida autorização também caberia à lei. ${ }^{620}$

${ }^{618}$ MenEZES, Cláudio Armando Couce de. O negociado sobre o legislado... Op. Cit., p. 158.

619 NASCIMENTO, Amauri Mascaro. Limites da negociação coletiva na perspectiva de projeto de flexibilização da CLT... Op. Cit., p. 1420. No mesmo sentido, a lição de Ives Gandra da Silva Martins Filho: "O objetivo da alteração do art. 618 da CLT foi o de explicitar melhor o que já se encontrava latente na Constituição Federal de 1988, quando admitiu a flexibilização de direitos trabalhistas mediante negociação coletiva em relação a salário e jornada de trabalho (CF, art. $7^{\circ}$, VI, XIII e XIV). Conforme já havíamos sustentado, se os dois principais direitos trabalhistas são passíveis de flexibilização, todos aqueles que deles decorrem, ou seja, parcelas de natureza salarial ou decorrentes da conformação da jornada de trabalho, também podem ser flexibilizados por acordos e convenções coletivas" (MARTINS FILHO, Ives Gandra da Silva. Valorização da negociação coletiva e flexibilização das normas legais trabalhistas... Op. Cit., p. 2).

${ }^{620}$ NASCIMENTO, Amauri Mascaro. Limites da negociação coletiva na perspectiva de projeto de flexibilização da CLT... Op. Cit., p. 1431. Entendimento análogo é defendido por MARTINS FILHO, Ives 
No mesmo sentido, Arion Sayão Romita sempre se mostrou defensor do Projeto $n^{\circ}$ 5.483/01; entretanto, reconheceu sua dificuldade de implementação no Brasil, no momento histórico em que foi apresentado. Afirmou o autor, à época de sua tramitação, que a proposta se antecipa à necessária reforma do texto constitucional e que seu teor "seria adequado a um regime democrático de regulação das relações de trabalho, atualmente desconhecido no direito brasileiro" - já que o ambiente de liberdade sindical, basilar para o desenvolvimento do quanto nele disposto, infelizmente ainda não foi implantado no Brasil. ${ }^{621}$

Porém, ainda assim, o autor entende que a supremacia do negociado sobre o legislado poderia ser levada a cabo por sindicatos filiados às centrais sindicais mais atuantes, como CUT e Força Sindical, pois representantes de contra-poder eficaz em face do poder econômico e estatal. Por tal motivo, o autor rechaça os posicionamentos no sentido de que a implementação do Projeto somente seria possível após reforma constitucional que consagrasse efetiva liberdade sindical. ${ }^{622}$

Entre as centrais sindicais, verificaram-se opiniões divergentes acerca do Projeto $n^{\circ}$ 5.483/01: enquanto a Força Sindical mostrou-se totalmente favorável a ele (inclusive engendrando procedimentos de negociação in peius durante sua tramitação no Congresso) ${ }^{623}$, a CUT e a CGT condenaram-no severamente, por entenderem que, se aprovado, este precarizaria diversos direitos consolidados do trabalhador. ${ }^{624}$

De qualquer maneira, o projeto, após aprovação na Câmara, foi encaminhado ao Senado Federal, onde tramitou sob o número PLC n ${ }^{\circ}$ 134/2001. Porém, não chegou sequer a ser votado nessa Casa do Congresso Nacional: inicialmente, seu regime de urgência foi cancelado em março de 2002, no contexto das negociações para aprovação da CPMF; posteriormente, porque, no ano eleitoral de 2002, o interesse pela reforma trabalhista (ainda mais flexibilizadora de direitos) perdeu força.

Gandra da Silva. Valorização da negociação coletiva e flexibilização das normas legais trabalhistas... Op. Cit., p. 2.

${ }^{621}$ RomitA, Arion Sayão. O Principio da Proteção em Xeque... Op. Cit..

${ }^{622}$ RomitA, Arion Sayão. O Princípio da Proteção em Xeque... Op. Cit.. Segundo o autor, "queimar etapas, em temas de natureza social, por vezes encarna providência salutar. Desejável seria - é óbvio - que a ordem natural das coisas fosse observada: primeiro a reforma do sistema sindical, depois a liberdade de negociação, como consequência natural. Tal desiderato, contudo, encontra óbice intransponível na resistência oposta pelos atores cujos interesses imediatos serão afetados pela reforma. A adoção da medida preconizada pelo projeto contribuirá, sem dúvida, para acelerar a reforma, pois deixará evidente o atraso exibido pelo sindicalismo oficial".

623 “Força já negocia direitos do trabalhador", Folha de São Paulo, edição de 16/12/2001.

624 “'Central prepara paralisação geral e propaganda contra a 'nova' CLT', Folha de São Paulo, edição de 23/12/2001. 
Finalmente, o projeto acabou sendo arquivado pela Câmara dos Deputados em 16 de junho de 2004, após aprovação do arquivamento pelo Senado Federal em 30 de abril de 2003, a pedido do então Presidente da República, Luiz Inácio Lula da Silva (por meio da Mensagem no 132/03).

$\mathrm{O}$ argumento utilizado para sustar o andamento de referido projeto foi de que alteração legislativa de tamanha magnitude demandaria, primeiramente, profunda reforma no sistema sindical brasileiro. Sustentou-se que seria extremamente pernicioso atribuir tarefa tão relevante aos sindicatos enquanto estes permanecerem fracos e carentes de representatividade, ainda mais em sistema de liberdade sindical contraditória e incompleta.

A respeito do tema, bem demonstra Amauri Mascaro Nascimento que houve desequilíbrio na história do Direito do Trabalho no que tange ao desenvolvimento de suas esferas: o direito coletivo não se desenvolveu, e o direito individual cresceu, exponencialmente, pela mão do Estado. Daí por que necessária a ampliação "do direito coletivo e sua função instrumental, criativa do direito individual". ${ }^{625}$

Embora tais ponderações sejam algo a se pensar, fato é que se perdeu oportunidade de implementar-se o contrato coletivo no direito brasileiro, sob pretexto de uma necessária reforma sindical que ainda terá longos anos de maturação até ser efetuada.

Arion Sayão Romita, nesse sentido, bem aponta os benefícios que adviriam da conversão de referido projeto em lei: ${ }^{626}$

a) Mudança do local onde ocorre a negociação entre empregado e empregador, passando das Varas do Trabalho para o sindicato. Por certo, grande parte das reclamações trabalhistas finda em acordos, em manifesta renúncia de direitos. Assim, com a aprovação do Projeto, a Justiça do Trabalho despojar-se-ia de referida função negociadora e passaria a exercer sua verdadeira atribuição: o julgamento;

b) Mudança do nível da negociação. Atualmente, como a negociação é efetuada nas Varas do Trabalho, pode-se afirmar que ocorre no nível individual (mediante ajuste entre o empregado e seu advogado e o empregador e seu advogado, envolvendo direitos exclusivos de um empregado, e não da categoria). A negociação pretendida

\footnotetext{
625 NASCIMENTO, Amauri Mascaro. Limites da negociação coletiva na perspectiva de projeto de flexibilização da CLT.. Op. Cit., p. 1421.

${ }^{626}$ RomitA, Arion Sayão. O Princípio da Proteção em Xeque... Op. Cit.
} 
pelo Projeto, entretanto, era coletiva, efetuada pelo sindicato e envolvendo direitos de todos os integrantes da categoria. E, nesse contexto, "os interesses dos trabalhadores serão considerados não como objeto de uma negociação individual processada em juízo, mas como fonte de direito, envolvendo os de toda uma coletividade";

c) Mudança do tempo em que ocorre a negociação. Como visto, atualmente, a negociação ocorre após o término do contrato de trabalho, transformando a Justiça do Trabalho na "justiça do desempregado" (quando deveria ser do empregado). Com o Projeto, a negociação abrangerá os contratos de trabalho vigentes e aqueles celebrados após a vigência da negociação coletiva. Disso, decorrerá redução do nível de conflitividade, pois a negociação será espontaneamente cumprida pelos empregadores, sob pena de ajuizamento da correspondente ação de cumprimento (mesmo porque o maior interessado no cumprimento da norma é aquele responsável por sua elaboração);

d) Mudança da natureza dos direitos negociados. Atualmente, a negociação envolve apenas direitos de natureza patrimonial e individual - e, portanto, disponíveis. A suposta irrenunciabilidade dos direitos existe apenas no papel, já que o crescimento do setor informal e a conciliação na Justiça do Trabalho ou eliminam pela raiz os supostos direitos (trabalhador removido para o setor informal não tem qualquer direito trabalhista) ou os transformam em direitos negociáveis em nível individual. Com o Projeto, os direitos que constituírem objeto da negociação coletiva serão indisponíveis em nível individual e só mediante novo processo de negociação poderão ser suprimidos, ampliados ou negociados. ${ }^{627}$

Durante o mandato do ex-Presidente Luiz Inácio Lula da Silva - após a retirada do Projeto de Lei $n^{0} 5.483$-, foi constituído o Fórum Nacional do Trabalho (FNT), instância tripartite com o objetivo de discutir alterações na legislação trabalhista. Como se sabe, as conclusões de referido Fórum evidenciaram pela necessária reforma do sistema sindical brasileiro antes de qualquer revisitação do diálogo das fontes, sob o argumento de que era preciso, em primeiro lugar, fortalecer os interlocutores sociais para, só depois, discutir alterações trabalhistas.

${ }^{627}$ RomitA, Arion Sayão. O Principio da Proteção em Xeque... Op. Cit. 
Foi, então, apresentada Proposta de Emenda à Constituição (PEC 369/2005), alterando dispositivos dos artigos $8^{\circ}, 11,37$ e 114 da Constituição Federal, para: a) instituir a contribuição negociada, a representação sindical nos locais de trabalho e a negociação coletiva para os servidores da Administração Pública; b) suprimir a unicidade sindical; c) incentivar a arbitragem para solução dos conflitos trabalhistas; e d) ampliar o alcance da substituição processual, permitindo que os sindicatos defendam, em juízo, direitos individuais homogêneos.

Referida Proposta da Reforma Sindical, porém, sequer foi apreciada pela Comissão de Constituição e Justiça e de Cidadania (CCJC) da Câmara dos Deputados até o presente momento.

Nos últimos anos, novos rumos têm tomado as discussões acerca da prevalência do negociado sobre o legislado, especialmente diante de inovadora iniciativa do Sindicato dos Metalúrgicos do ABC Paulista e da Central Única dos Trabalhadores (CUT). Com efeito, em 30 de setembro de 2011, tais entidades apresentaram, à Presidência da República, Anteprojeto de Lei que reconhece espécie de contrato coletivo de trabalho, denominado "Acordo Coletivo de Trabalho com Propósito Específico" (ou "Acordo Coletivo Especial" - ACE), a ser celebrado diretamente entre a empresa e o "Comitê Sindical de Empresa", formado por representantes dos trabalhadores no local de trabalho.

$\mathrm{Na}$ apresentação de referido Anteprojeto, Sérgio Nobre, então Presidente do Sindicato dos Metalúrgicos do ABC, salientou que a ideia nasceu do desejo de que o Brasil "adote a negociação coletiva como instrumento mais moderno para a solução dos conflitos pertinentes às relações de trabalho e à representação sindical no interior da fábrica, como condição fundamental à democratização das relações entre trabalhadores e empresas". ${ }^{628}$ O intuito é de flexibilizar a legislação por meio da negociação coletiva, adaptando-a aos interesses específicos da empresa em determinado momento de sua atividade.

O ACE, nesse sentido, corresponde a acordo a ser celebrado diretamente entre uma empresa e o respectivo sindicato profissional, diante de motivação específica para sua discussão. Jamais poderá envolver mais de uma empresa ou o sindicato de categoria econômica, eis que ligado às condições peculiares da empresa celebrante. De

\footnotetext{
628 Cartilha sobre o ACE - Acordo Coletivo Especial, disponível online em http://www.smabc.org.br/Interag/temp_img/\%7B016A7A92-EDB2-48D8-8734F9C3617D2E1A\%7D_cartilha_ace_v4_nova.pdf.
} 
qualquer maneira, permite-se às organizações sindicais do setor econômico a que pertence a empresa acompanharem as negociações, quando solicitado.

Entretanto, do Anteprojeto, constam severos requisitos a serem preenchidos pelo sindicato e pela empresa para a celebração dos acordos.

De sua parte, o sindicato profissional deverá obter habilitação junto ao Ministério do Trabalho e Emprego ${ }^{629}$ - a qual somente será fornecida se instalado em uma ou mais empresas de sua base de representação o Comitê Sindical de Empresa, composto por no mínimo dois e no máximo 32 membros. Ademais, deverá a entidade contar com índice mínimo de sindicalização de 50\% mais 1 do total dos trabalhadores da empresa.

Importante ressaltar que o Comitê Sindical de Empresa (CSE) é previsto expressamente pelo Estatuto do Sindicato dos Metalúrgicos do ABC e corresponde a unidade de representação desse Sindicato instalada nos locais de trabalho. O Comitê é composto por diretores sindicais e poderá ser constituído em cada uma das empresas da base territorial do Sindicato, por iniciativa de sua direção, ou por manifestação escrita de 2/3 dos associados da empresa, desde que o número de trabalhadores sindicalizados corresponda a mais de $50 \%$ mais 1 dos trabalhadores que exercem suas atividades profissionais na referida empresa. O número de membros do Comitê depende do número de sindicalizados da empresa, variando de 2 a 32 membros. ${ }^{630}$

Por seu turno, a empresa deverá reconhecer o Comitê Sindical como órgão de representação do sindicato profissional no local de trabalho (mediante acordo coletivo celebrado para esse fim) e não poderá possuir qualquer pendência em ação

\footnotetext{
${ }^{629}$ Criticada por Davi Furtado Meirelles por suscitar risco de retorno à ingerência do Estado na atividade sindical (MEIRELlES, Davi Furtado. Em defesa do acordo coletivo com propósito específico. In Revista da Faculdade de Direito de São Bernardo do Campo. São Bernardo do Campo, 2013, disponível online em http://www.direitosbc.br/Data/Sites/2/arquivos_servidor_fdsbc/revista_caderno/volume_19_2013/03_emdefesa-do-acordo-coletivo-com-propósito-espec\%C3\%ADfico.pdf., p. 73)

${ }^{630}$ As atribuições do Comitê Sindical de Empresa vêm previstas no art. 26 do Estatuto do Sindicato dos Metalúrgicos do ABC: “Art. 26 - Os Comitês Sindicais de Empresa tem as seguintes finalidades a-) representar o Sindicato dos Metalúrgicos no âmbito da empresa; b-) representar os trabalhadores sindicalizados perante a empresa e nas instâncias do Sindicato; c-) levar para dentro das empresas o trabalho e a cultura da associação de classe a todos os trabalhadores, incentivando e promovendo a sindicalização; d-) encaminhar reivindicações, negociações e todos os demais atos decorrentes da luta sindical no âmbito da empresa; e-) encaminhar e implementar junto aos trabalhadores nas empresas as lutas e questões relativas aos interesses específicos da categoria metalúrgica demandados pelo Sindicato; f-) acompanhar e físcalizar o cumprimento por parte da empresa das cláusulas dos acordos, convenções e contratos coletivos de trabalho; g-) trabalhar pelo fortalecimento das representações internas de trabalhadores, quando houver coincidência nos objetivos e princípios fundamentais; h-) Concorrer nas eleições dos órgãos de Representação Interna dos Trabalhadores das empresas a que estão ligados".
} 
condenatória proposta pelo sindicato em consequência de restrições ao exercício de direitos sindicais.

A aprovação do acordo ocorrerá em escrutínio secreto, assegurada a participação de, no mínimo, $50 \%$ dos trabalhadores abrangidos pelo percentual de $60 \%$ por cento ou mais dos votos apurados. Nos termos do Anteprojeto, ainda, o Acordo Coletivo Especial terá validade de três anos, salvo se, antes desse período, houver perda da habilitação do sindicato ou da empresa, nos termos das condições acima descritas. Porém, as cláusulas em vigor há mais de quatro anos poderão ser renovadas por prazo indeterminado, conforme a vontade das partes.

É preciso, ademais, consignar no instrumento normativo as razões que justificam a adaptação da legislação ao caso individual.

O Anteprojeto regulamenta, também, a atuação da Fiscalização do Trabalho diante da existência de Acordo Coletivo Especial: esta deverá verificar se as exigências formais para celebração do acordo foram integralmente atendidas e se as condições de trabalho, na prática, observam o quanto acordado.

Como se vê, o Anteprojeto do Sindicato dos Metalúrgicos congrega dois intentos diversos, porém diretamente relacionados: em primeiro lugar, busca a criação do contrato coletivo (de forma a permitir a prevalência do negociado sobre o legislado no âmbito empresarial) e, em segundo, a legitimação das entidades aptas a celebrar referidos contratos, deixando entrever certa inspiração no modelo de representatividade sindical especialmente adotado por países europeus.

O Anteprojeto ainda não foi apresentado ao Congresso Nacional. Inobstante, já suscita discussões, entre as próprias entidades e centrais sindicais. Afirma-se que o ACE abre caminho para a possibilidade de divisão das férias em várias parcelas, pagamento fracionado do $13^{\circ}$ salário, banco de horas sem limites, contratação temporária e aumento das terceirizações, reduções salariais injustificadas, etc. ${ }^{631}$ Ademais, a proposta foi rechaçada, também, por comissão de notáveis juristas e pensadores ${ }^{632}$, sob o argumento de que a verdadeira modernidade do Direito do Trabalho somente será atingida se se "compreender a necessidade do desenvolvimento constante de uma racionalidade

\footnotetext{
${ }^{631}$ Veja-se, por exemplo, o manifesto de repúdio ao Anteprojeto, apresentado pela CSP-Conlutas, disponível online em http://www.ilaese.org.br/wp-content/uploads/2013/03/Palestra.ACE+final-editado.pdf.

${ }^{632}$ Entre os quais se destacam Chico de Oliveira, Guilherme Guimarães Feliciano, Janaina Vieira de Castro, Jorge Luiz Souto Maior, Júlio César Bebber, Luciano Martinez, Marcus Orione Gonçalves Correia, Ricardo Antunes, Ronaldo Lima dos Santos, etc.
} 
efetivamente voltada ao resgate da dignidade humana, aprisionada que fora pela lógica produtiva concorrencial, pautada por interesses estritamente econômicos". 633

Todavia, como ressalta Helio Zylberstajn, a proposta advém de modelo de relação de trabalho peculiar que o Sindicato dos Metalúrgicos e empresas parceiras vêm desenvolvendo nos últimos quinze anos, avançando para além da lei na negociação das condições de trabalho. Agora, o objetivo é conferir segurança jurídica para tais avanços, de forma a evitar questionamentos e recuos causados por ações de órgãos como a Inspeção do Trabalho e o Ministério Público do Trabalho. ${ }^{634}$

Nessa atuação peculiar do Sindicato dos Metalúrgicos do ABC, mostrouse emblemático o acordo celebrado entre este e a Volkswagen, em 1999 - quando a empresa, em virtude de séria crise econômica, viu-se obrigada a negociar acordo para redução de jornadas e, proporcionalmente, de salários. Entretanto, com o intuito de evitar que o trabalhador viesse a perder poder de compra em seu salário, foi estipulado que, durante os dois anos de vigência do acordo de redução salarial (1999 e 2000), a participação nos lucros e resultados seria paga da seguinte forma: 50\% de uma única vez e os outros 50\% divididos em 12 parcelas iguais e mensais (em manifesta contradição, portanto, com o que prevê a Lei $\mathrm{n}^{\mathrm{o}} 10.101 / 00$ acerca da periodicidade de pagamento da PLR).

Referido acordo foi, então, alvo de inúmeras reclamações trabalhistas. Destas, resultaram decisões divergentes nos órgãos judiciários pátrios, até que o caso chegou ao Tribunal Superior do Trabalho - o qual, acertadamente, posicionou-se pela legalidade da negociação, sedimentando tal posicionamento na Orientação Jurisprudencial Transitória $\mathrm{n}^{\mathrm{o}} 73$, da Seção de Dissídios Individuais I, in verbis:

OJ-Transitória-SDII-73, TST. VOLKSWAGEN DO BRASIL LTDA. PARTICIPAÇÃO NOS LUCROS E RESULTADOS. PAGAMENTO MENSAL EM DECORRÊNCIA DE NORMA COLETIVA. NATUREZA INDENIZATÓRIA.

A despeito da vedação de pagamento em periodicidade inferior a um semestre civil ou mais de duas vezes no ano cível, disposta no art. $3^{\circ}, \S 2^{\circ}$, da Lei n. ${ }^{\circ} 10.101$, de 19.12.2000, o parcelamento em prestações mensais da participação nos lucros e resultados de janeiro de 1999 a abril de 2000, fixado no acordo coletivo celebrado entre o Sindicato dos Metalúrgicos do $\mathrm{ABC}$ e a Volkswagen do Brasil Ltda., não retira a natureza indenizatória da

\footnotetext{
${ }^{633}$ Manifesto disponível online em http://cspconlutas.org.br/2012/08/manifesto-de-juristas-nao-ao-projetode-acordo-com-proposito-especifico-do-smabc/\#sthash.INNMrxsJ.dpuf

${ }^{634}$ ZYLBERSTAJn, Hélio. Reforma Trabalhista. In Estadão.com.br, caderno Opinião. 18 de janeiro de 2011.
} 
referida verba (art. $7^{\circ}, \mathrm{XI}$, da $\mathrm{CF}$ ), devendo prevalecer a diretriz constitucional que prestigia a autonomia privada coletiva (art. $7^{\circ}$, XXVI, da CF).

No mesmo sentido, inúmeros vêm sendo os acordos celebrados por referido sindicato em matéria de redução de intervalos intrajornada, compensação de jornada insalubre e outros direitos que - embora, à primeira vista, pareçam contrariar normas de saúde e segurança no trabalho - podem trazer benefícios diretos ao trabalhador (como redução do tempo de permanência na empresa, supressão do trabalho aos sábados, etc.). Todavia, esses acordos não têm logrado êxito, na Justiça do Trabalho: são sumariamente rechaçados, sob o argumento de combate à precarização de direitos do trabalhador.

De qualquer maneira, conforme expõe Davi Furtado Meirelles, pode-se afirmar que o Sindicato dos Metalúrgicos do ABC adquiriu enorme respeitabilidade no campo das relações de trabalho ao longo dos anos, pois responsável pelo "novo sindicalismo" no Brasil, haja vista as gigantescas greves iniciadas em 1978. Graças a esse movimento, surgiram as primeiras centrais sindicais brasileiras e as representações dos trabalhadores no interior das empresas, bem como foram consagrados constitucionalmente direitos advindos da negociação coletiva. ${ }^{635}$

Ainda, com os metalúrgicos do $\mathrm{ABC}$, surgiram os Sistemas Únicos de Representação (SUR), que uniram as representações internas na empresa com as atribuições da CIPA. E as próprias CIPAs foram transformadas em Comissões de Saúde e Meio Ambiente de Trabalho, com representação exclusiva de trabalhadores, sem o formalismo da legislação trabalhista. Também foram instituídos os Comitês Sindicais de Empresa (CSEs), cujos membros são eleitos pelos associados do sindicato em processo eleitoral dentro das próprias fábricas (ressaltando-se que o CSE só pode ser constituído se na empresa trabalharem 50\% mais um de associados do sindicato, em relação ao número total de trabalhadores da mesma unidade empresarial).

A proposta de alteração legislativa, assim, parte de sindicato engajado, verdadeiramente representativo e, por tal razão, ciente das necessidades concretas enfrentadas por empresários e trabalhadores nas atuais relações laborais.

${ }^{635}$ MeIRELles, Davi Furtado. Em defesa do acordo coletivo com propósito específico... Op. Cit., pp. 64-65. 
Talvez dois tenham sido os equívocos do Anteprojeto para celebração do "Acordo Coletivo de Trabalho com Propósito Específico", que causaram o entrave para sua apresentação ao Congresso Nacional: em primeiro lugar, a ausência de especificação de matérias que poderiam ou não ser objeto dos contratos coletivos de trabalho; em segundo, a desconsideração da realidade disforme que atinge os sindicatos brasileiros, muitos dos quais ainda não apresentam maturidade suficiente para negociar condições de trabalho diretamente com as empresas, sem sofrer qualquer tipo de pressão por parte delas. $^{636}$

Em 2012, de qualquer maneira, novos ares ganham as propostas de reforma da legislação em matéria de prevalência do negociado sobre o legislado: o Projeto de Lei $n^{\circ}$ 4.193, apresentado pelo Deputado Irajá Abreu (PSD/TO), em 11 de julho desse ano, sugere alteração da relação do art. 611, da Consolidação das Leis do Trabalho, nos seguintes termos:

Art. 611, CLT. É assegurado o pleno reconhecimento das convenções e acordos coletivos de trabalho.

$\S 1^{\circ}$ Convenção coletiva de trabalho é o acordo de caráter normativo, pelo qual dois ou mais sindicatos representativos de categorias econômicas e profissionais estipulam condições de trabalho aplicáveis, no âmbito das respectivas representações, às relações individuais do trabalho.

$\S 2^{\circ}$ É facultado aos sindicatos representativos de categorias profissionais celebrar acordos coletivos com uma ou mais empresas da correspondente categoria econômica, que estipulem condições de trabalho, aplicáveis no âmbito da empresa ou das empresas acordantes às respectivas relações de trabalho.

$\S 3^{\circ}$ As federações e, na falta destas, as confederações representativas de categorias econômicas ou profissionais poderão celebrar convenções coletivas de trabalho para reger as relações das categorias a elas vinculadas, inorganizadas em sindicatos, no âmbito de suas representações.

$\S 4^{\circ}$ As normas de natureza trabalhista, ajustadas mediante convenção ou acordo coletivo, prevalecem sobre o disposto em lei, desde que não contrariem as normas de ordem constitucional e as normas de higiene, saúde e segurança do trabalho.

$\S 5^{\circ} \mathrm{Na}$ ausência de convenção ou acordo coletivo, ou sendo esses instrumentos omissos, incompletos, inexatos conflitantes ou de qualquer forma inaplicáveis, prevalecerá sempre o disposto em lei.

\footnotetext{
${ }^{636}$ Embora, como visto, haja a necessidade de reconhecimento do sindicato pelo Ministério do Trabalho, corre-se o risco de tal reconhecimento, diante do preenchimento dos requisitos formais, ser concedido a entidades compostas por sindicalistas pelegos, facilmente corruptíveis pelas empresas.
} 
Para o tema que interessa ao presente trabalho, destacam-se os parágrafos $4^{\circ}$ e $5^{\circ}$ do artigo supracitado, os quais, mais uma vez, pretendem a sobreposição da negociação coletiva em relação à lei, ressalvados apenas os direitos constitucionais e as normas de higiene, saúde e segurança do trabalho. Retoma-se, assim, a proposta apresentada pelo governo FHC, quase que em sua literalidade.

O Projeto encontra-se em trâmite na Câmara dos Deputados. Em 05 de outubro de 2013, a Comissão de Trabalho, de Administração e Serviço Público (CTASP) requereu a realização de audiência pública com as Centrais Sindicais e as Confederações Patronais para discussão do Projeto - a qual ocorreu em 03 de dezembro de 2013. Muitos foram os ataques ao Projeto nessa audiência, razão pela qual o Deputado Roberto Santiago, Presidente da CTASP, afirmou que este não seria votado na Comissão (apesar de o Relator, Deputado Silvio Costa, já ter apresentado parecer favorável a sua aprovação). ${ }^{637}$

Em 09 de abril de 2014, foi apensado ao Projeto $n^{\circ} 4.193$ o Projeto de Lei $n^{\circ} 7.341 / 2014$, apresentado pelo Deputado Diego Andrade, o qual pretende estabelecer a prevalência das convenções coletivas de trabalho sobre as Instruções Normativas expedidas pelo Ministério do Trabalho, mediante alteração do art. 611, da CLT, nos seguintes termos:

\begin{abstract}
Art. 611, CLT - ...
$\S 3^{\circ}$ A Convenção Coletiva de Trabalho prevalece sobre a Instrução Normativa expedida pelo Ministério do Trabalho, ainda, que verificada a existência de conflitos ou divergências entre ambas.
\end{abstract}

Conforme já antecipado pelo Presidente da CTASP, ambos os projetos permanecem parados nessa Comissão, desde 14 de maio de 2014.

Das propostas de alteração legislativa, para prevalência do negociado sobre o legislado no Brasil, pode-se extrair aspecto comum: todas encontram severas resistências por parte de certas entidades sindicais - mesmo aquelas que são de iniciativa das próprias classes profissionais. Se o consenso não será obtido, é preciso, então,

${ }^{637}$ Conforme notícia disponível online em http://www2.camara.leg.br/camaranoticias/noticias/TRABALHOE-PREVIDENCIA/458550-DIANTE-DE-DIVERGENCIAS,-PROJETO-SOBRE-ACORDOS-

COLETIVOS-NAO-SERA-VOTADO-EM-COMISSAO.html. 
apresentar parâmetros a fim de que referida reforma - imprescindível para o adequado desenvolvimento das relações trabalhistas no século XXI - opere-se da forma mais segura possível, sem afrontar direitos consolidados, e independentemente da modificação do sistema do sindicalismo no Brasil (reforma que é por todos almejada, mas ainda tem muitos anos de maturação pela frente).

Fato é que, como bem ressalta Amauri Mascaro Nascimento, a atribuição de maiores poderes à negociação coletiva é tema que extrapola os limites da ciência jurídica, envolvendo avaliações que pressupõem o pleno conhecimento do mercado de trabalho e que, portanto, são afetas a outras ciências, como Economia, Administração, etc. ${ }^{638}$ Portanto, posicionamentos puramente ideológicos, pautados em uma suposta inderrogabilidade absoluta da normativa trabalhista, devem ser sumariamente rechaçados, para analisar a realidade, in concreto, das relações laborais hodiernas no Brasil.

638 NASCIMENTO, Amauri Mascaro. Limites da negociação coletiva na perspectiva de projeto de flexibilização da CLT... Op. Cit., p. 1419. 


\section{Bases e limites para a adoção, no Brasil, do modelo negociado}

Conforme reiteradamente afirmado neste estudo, é imperiosa a adoção do modelo negociado, em prevalência ao legislado, no Brasil - como em qualquer outro ordenamento jurídico que enfrente as profundas alterações sofridas pelo trabalho nas últimas décadas.

Porém, a modificação do sistema de relações trabalhistas não pode ocorrer de forma leviana - como pretendem algumas das propostas legislativas verificadas em solo pátrio até o momento -, nem tampouco se pode copiar a experiência de outros países, cuja realidade sempre será distinta da brasileira.

É preciso, assim, apontar as bases e os limites para a adoção do modelo negociado no Brasil. Em outras palavras: deve-se, inicialmente, perquirir quais fundamentos autorizam o fortalecimento da autonomia privada coletiva neste país, para, em seguida, delinear sua abrangência, estipulando limites de atuação.

Pense-se, por exemplo, na construção de um edifício empresarial: é necessário fincar os alicerces para evitar que este desmorone, e, uma vez terminada a obra, cumpre estabelecer regras de convivência entre os condôminos para assegurar o bom andamento das relações comerciais nele desenvolvidas. 


\subsection{Bases}

\section{a) A função do Direito do Trabalho é tutelar não o trabalhador, mas o trabalho em si}

Já se afirmou, em outra ocasião, que Amauri Mascaro Nascimento questiona a função do Direito do Trabalho hodierno, a qual, em quadro de avanços tecnológicos e novos rumos da economia, passa a ser a defesa do emprego, e não mais a ampliação de direitos trabalhistas. ${ }^{639}$

No entanto, melhor seria dizer - como o faz Arion Sayão Romita ${ }^{640}$ - que a proteção do trabalhador nunca foi a função precípua do Direito do Trabalho, mas simplesmente a característica (ou o particularismo, na visão de Antoine Jeammaud ${ }^{641}$ ) que lhe assegurou autonomia em relação aos demais ramos do Direito.

Ao Direito do Trabalho cabe, sim, a proteção - mas a proteção da relação de emprego, do bom relacionamento de suas partes, do sinalagma existente entre elas. A própria legislação brasileira, aliás, demonstra tal função, mediante a positivação de institutos como justa causa (art. 482 da CLT), suspensão disciplinar (art. 474 da CLT), limitação ao direito de greve (Le $\mathrm{n}^{\mathrm{o}}$ 7.783/89), ius variandi (art. 468, parágrafo único, da CLT; art. 469, $\S \S 1^{\circ}$ a $3^{\circ}$, da CLT; etc.), inquérito para apuração de falta grave (arts. 853 a 855 da CLT), entre outras medidas de "tutela" do empregador na relação empregatícia.

Indo além, melhor seria falar na função de tutela da relação de trabalho como um todo, já que também compete a esse ramo do Direito atribuir segurança a novas formas de contratação, por exemplo, garantindo determinados direitos ao parassubordinado e afastando a presunção de fraude da pejotização.

Em síntese: ao Direito do Trabalho compete a proteção do trabalho como um todo, enquanto instrumento capitalista de produção e socialista de dignificação humana - a par de qualquer inclinação para uma ou outra dessas duas ideologias.

\footnotetext{
${ }^{639}$ Nascimento, Amauri Mascaro. Curso de Direito do Trabalho... Op. Cit., p. 70 (Cf. supra, capítulo 4, item 4.1). O mesmo autor, em outra obra, aponta as seguintes funções atuais do Direito do Trabalho: função tutelar, função conservadora ou opressora do Estado, função econômica, função social e função coordenadora - para mais informações, cf. NASCIMENTO, Amauri Mascaro. Iniciação ao Direito do Trabalho..., Op. CIT., pp. 70 e ss.

${ }^{640}$ Romita, Arion Sayão. O Princípio da Proteção em Xeque... Op. Cit..

${ }^{641}$ JeammaUd, Antoine. Droit du Travail... Op. Cit. (Cf. supra, capítulo 4, item 4.2).
} 


\section{b) A ideologia da proteção apenas reforça a posição de submissão do trabalhador}

Para Arion Sayão Romita, quem fala em proteção admite a existência de dois atores sociais: o protetor e o protegido. Se o trabalhador é o protegido, sua posição de submissão "se perpetua com a consequente exaltação da posição social do protetor". Por isso, a "proteção" interessa não ao protegido, e sim ao protetor. Ao protegido, aquela só interessa "quando fundamenta (quase sempre de forma não explícita) a decisão judicial pela procedência do pedido formulado pelo trabalhador. Triste consolo, triste participação nas migalhas caídas da mesa do banquete!"

É preciso que o próprio trabalhador conscientize-se de seu papel na sociedade. Hoje, este é tratado por muitos como simples "recebedor" de direitos, que lhe são doados pelo Estado, garantidos pelo empregador e reforçados pelo Poder Judiciário. Ou seja, intensifica-se a posição de inferioridade justamente daquele que, com sua força de trabalho, movimenta a economia e detém plena capacidade de interferir nos rumos políticos do país.

A Constituição Federal de 1988, por certo, rompeu - embora discretamente - com essa posição de submissão. No plano coletivo, como já afirmado, assegurou liberdade sindical (ainda que contraditória) e reconheceu a força das convenções, além de regulamentar a representação no interior da empresa. No âmbito individual, previu a participação do empregado nos lucros e na gestão empresarial. No campo social, garantiu a atuação dos trabalhadores nos colegiados de órgãos públicos responsáveis pela gestão de seus interesses.

O posicionamento constitucional, entretanto, é frequentemente ignorado pelos operadores do Direito, sobretudo pelos órgãos de tutela das relações trabalhistas (i.e., Justiça do Trabalho, Ministério Público do Trabalho e Ministério do Trabalho). Com efeito, ao mesmo tempo em que referidos órgãos ignoram o interesse concreto do trabalhador $^{643}$, oneram as empresas baseados em dispositivos legais obsoletos ${ }^{644}$ ou extremamente detalhistas e de difícil aplicabilidade ${ }^{645}$

\footnotetext{
${ }^{642}$ RomitA, Arion Sayão. O Principio da Proteção em Xeque... Op. Cit..

${ }^{643}$ Como ocorre, por exemplo, na pejotização: muitos trabalhadores preferem referida forma de contratação, por ser financeiramente mais interessante - ainda assim, os órgãos de tutela das relações trabalhistas simplesmente desconsideram esse "querer", sob o argumento da hipossuficiência do prestador de serviços.

${ }^{644}$ Veja-se, por exemplo, o emblemático caso do art. $134, \S 2^{\circ}$, da CLT, que proíbe o fracionamento das férias ao empregado maior de 50 anos. Se tal previsão justificava-se à época de sua inserção na CLT (1977), atualmente não encontra mais justificativa plausível, diante do incremento da expectativa de vida do trabalhador e, por conseguinte, de sua vida laboral. Entretanto, ainda assim, as empresas vêm sofrendo
} 
E, isso tudo, quando a extensa rede de proteções não se volta contra o próprio trabalhador, direta ou indiretamente.

Diretamente, a proteção volta-se contra seu destinatário, por exemplo, no que tange ao salário in natura: a regra geral de integração de utilidades ao salário enseja, a redução de vantagens concedidas pelo empregador - já que, quanto mais utilidades, maiores serão seus gastos. ${ }^{646}$ De outra parte, indiretamente, como o excesso de proteção onera os custos da empresa, estes acabam sendo repassados aos preços dos produtos e serviços e, "como os consumidores ou usuários são, em última análise, os próprios trabalhadores, segue-se que o ônus econômico decorrente da proteção recai sobre o trabalhador". ${ }^{647}$ Isso sem falar, é claro, no repasse dos custos mediante a redução do salário líquido do empregado.

Interessante análise a respeito é proposta por Homero Matheus Batista da Silva. O autor busca responder o que poderia ser, efetivamente, considerado como alteração maléfica ao empregado - já que referida questão deveria ser examinada sob diferentes ângulos. ${ }^{648}$

Segundo o autor, habitualmente se associa a questão financeira à alteração maléfica ou benéfica, de forma que qualquer redução de ganhos costuma ser vista como prejudicial ao empregado. Porém, em realidade, algumas alterações redutoras de ganhos são efetivamente benéficas, do ponto de vista da saúde ou segurança do trabalhador; assim, por exemplo, a eliminação do agente insalubre ou perigoso, ou do trabalho noturno, entre outras.

aplicação de multas administrativas no caso de violação a essa regra, e o TST firmou entendimento no sentido de que o fracionamento das férias do maior de 50 anos enseja pagamento em dobro do período: “(...)

FÉRIAS. FRACIONAMENTO IRREGULAR. EMPREGADA COM MAIS DE 50 ANOS. ARTIGO 14 DA CLT. PAgAMento EM DOBRo. Esta Corte firmou o entendimento de que deverão ser remuneradas em dobro as férias concedidas com irregularidade ou não concedidas, porquanto o fracionamento irregular equivale a não concessão, impondo como consequência o pagamento em dobro acrescido de 1/3. Precedentes (...) (TST - RR: 422000520095060005 42200-05.2009.5.06.0005, Relator: Emmanoel Pereira, Data de Julgamento: 22/06/2011, $5^{\text {a } T u r m a, ~ D a t a ~ d e ~ P u b l i c a c ̧ a ̃ o: ~ D E J T ~ 01 / 07 / 2011) . ~}$

${ }^{645}$ Assim, por exemplo, as inúmeras instruções normativas do Ministério do Trabalho - como a $\mathrm{n}^{\circ} 90$, de 2011, que prevê complexo procedimento a ser observado pela empresa no caso de contratação de empregado em um local para prestar serviços em outro e que vem sendo objeto de inúmeras ações civis públicas, por parte do Ministério Público do Trabalho, diante de seu suposto descumprimento pelos empregadores (nesse sentido, cf. notícia publicada em janeiro de 2014 no site http://mptprt16.jusbrasil.com.br/noticias/100666605/mpt-ma-investiga-33-casos-de-aliciamento-de-trabalhadores).

${ }^{646}$ Tanto é verdade que a inserção do art. 458, §2 $2^{\circ}$, da CLT, ocorrida em 2001, deu-se justamente com o intuito de fomentar a concessão de utilidades pelo empregador, retirando a natureza salarial de diversas vantagens antes tributadas pela legislação.

${ }^{647}$ RomitA, Arion Sayão. O Princípio da Proteção em Xeque... Op. Cit..

${ }^{648}$ Silva, Homero Batista Matheus da Silva. Curso de Direito do Trabalho Aplicado - Parte Geral. $2^{\mathrm{a}}$ Ed. Rio de Janeiro: Elsevier, 2013, pp. 756 e ss. 
Antonio Carlos Aguiar, por seu turno, afirma que a fragilidade do empregado na relação contratual não passa de um mito. O "travamento legal" de seu contrato de trabalho e a presunção de uma incapacidade jurídica genética para celebrar condições contratuais apenas se justificam em ambiente que não admite a negociação coletiva - já que, quando representado por seu sindicato, o trabalhador despoja-se de referida incapacidade. ${ }^{649}$

É preciso, pois, reconhecer maior autonomia ao trabalhador, afastando o viés estritamente paternalista incorporado no Brasil desde o Estado Novo. O empregado, sem dúvida, precisa ser protegido - mas também deve ser ouvido.

\section{c) A função atual da negociação coletiva não é, apenas, de ampliar os direitos legais, mas preencher vazios da lei e administrar (e prevenir) crises econômicas}

Segundo leciona Amauri Mascaro Nascimento, são funções tradicionais da negociação coletiva: a) compositiva (harmonizar interesses contrapostos dos trabalhadores e empregadores); b) normativa (criar normas que serão aplicadas às relações individuais de trabalho); c) política (propiciar diálogo entre os grupos sociais, em uma sociedade democrática); d) econômica (ensejar a distribuição de riquezas em economia próspera); e) social (garantir a participação dos trabalhadores no processo de decisão empresarial). ${ }^{650}$

A contratação coletiva apresenta diversas vantagens em relação à lei. A primeira delas, certamente, é a celeridade de seu processo de negociação - importante, sobretudo, quando a regulamentação de condições de trabalho tem caráter emergencial, como durante crises econômicas. A segunda, sem sombra de dúvida, é sua capacidade de "especificação" de direitos, ou seja, adaptação da lei às necessidades concretas das partes sociais - tantas vezes já ressaltada no presente trabalho.

\footnotetext{
${ }^{649}$ AgUiAr, Antonio Carlos. Negociação coletiva de trabalho. São Paulo: Saraiva, 2001, pp. 100-101.

${ }^{650}$ Nascimento, Amauri Mascaro. Compêndio de Direito Sindical... Op. Cit., pp. 485-487. Na célebre obra "Diritto Sindacale", Gino Giugni afirma que, desde suas origens e independentemente da cultura que o inspirava, o movimento sindical "ha avuto tra $i$ suoi fini primari quello di ottenere minimi di tutela economica e normativa delle condizioni di vita e di lavoro dei lavoratori" ("teve entre seus fins primários aqueles de obter mínimos de tutela econômica e normativa das condições de vida e de trabalho dos trabalhadores" - tradução livre), quer mediante a contratação com a contraparte empresarial, quer mediante ações políticas visando a influenciar a orientação legislativa (GIUGNI, Gino. Diritto Sindacale... Op. Cit., p. $125)$.
} 
Diante de tais vantagens, entende-se que duas novas funções poderiam ser acrescentadas ao elenco proposto por Amauri Mascaro Nascimento, a saber:

(i) O gerenciamento de crises econômicas, incluída sua prevenção: a doutrina já vêm reconhecendo a capacidade gerencial das convenções e dos acordos coletivos de trabalho ${ }^{651}$, os quais se mostram importantes instrumentos de "desregulamentação controlada e condicionada" 652 da legislação em épocas de crise econômica. ${ }^{653}$ É preciso, entretanto, ampliar essa função gerencial para permitir, também, a prevenção de crises pela contratação coletiva.

José Pastore apresenta elucidativo exemplo, ocorrido na União Europeia: com a entrada de países do leste europeu na Comunidade, verificou-se grande divergência de condições de trabalho, já que, enquanto nesses países o salário médio era de três a seis dólares por hora e os trabalhadores cumpriam jornadas mais longas, nos países ocidentais o salário médio era de trinta e cinco dólares por hora, com jornadas mais curtas (sendo emblemático o caso da França, onde a duração semanal do trabalho é de 35 horas).

Naturalmente, assim, muitas empresas passaram a migrar para o lado oriental, com intuito de redução de custos, gerando desemprego entre os países do Ocidente.

A negociação coletiva, nessa ocasião, foi crucial para evitar crise econômica generalizada na Europa Ocidental: por meio de contratos coletivos, acordou-se ampliação da duração semanal do trabalho dos empregados desses países (normalmente, de 35 para 40 horas), sem o correspondente aumento de salários, mas em troca do compromisso de as fábricas ficarem nos países até $2012{ }^{654}$

Ou seja: nas situações em que crises se anunciam - embora ainda não estejam instaladas - a negociação coletiva pode vir a ser importante instrumento de estabilização da economia. ${ }^{655}$

\footnotetext{
${ }^{651}$ Recordem-se, a respeito, os ensinamentos da doutrina italiana acerca da funzione gestionale dos contratos coletivos de trabalho: cláusulas que permitem a escolha de empregados a serem dispensados, contratos de trabalho que serão suspensos, entre outros (Cf. GALANTINO, Luisa. Diritto sindacale... Op. Cit., pp. 126-128 e supra, capítulo 4, item 4.3.3).

${ }^{652}$ NASCIMENTO, Amauri Mascaro. Compêndio de Direito Sindical... Op. Cit., p. 448.

${ }^{653}$ Recorde-se o exemplo do acordo de PLR parcelada negociado pelo Sindicato dos Metalúrgicos do ABC (cf. supra, capítulo 5, item 5.3)

${ }^{654}$ PASTORE, José. Redução de jornada gera emprego? In Revista do Tribunal Superior do Trabalho, Brasília, vol. 75, no 2, abr/jun 2009, p. 90-91.

${ }^{65}$ A esse respeito, aliás, é mister recordar a estreita relação entre Direito do Trabalho e Economia, na medida em que "são as relações entre o capital e o trabalho, por intermédio da organização, para fins de produção e serviços, que constituem o objeto principal da Economia" - e outro não é o objeto do Direito do
} 
É o que afirma, com efeito, Alain Supiot, para quem, do ponto de vista jurídico, a negociação coletiva aparece como alternativa à aplicação da lei na especificação de condições de trabalho conforme os interesses concretos da prestação de serviços. ${ }^{656}$

(ii) A regulamentação de vazios da lei: sabe-se que a legislação trabalhista não consegue acompanhar o dinamismo das mudanças políticas, sociais e econômicas; por isso, é natural que surjam lacunas envolvendo novas profissões, tecnologias e métodos de prestação de serviços.

Nessas situações, duas posturas vêm sendo adotadas no ordenamento brasileiro: a) a jurisprudência cuida de preencher esses vazios, mediante a edição de súmulas e orientações jurisprudenciais - gerando um mar de posicionamentos consolidados que confundem o intérprete e os próprios órgãos julgadores ${ }^{657}$; b) o legislador busca regulamentar as novas realidades a toque de caixa - levando, inevitavelmente, à deficiência da legislação feita às pressas, que acaba trazendo mais dúvidas do que certezas. ${ }^{658}$

Melhor seria, portanto, permitir aos próprios interlocutores sociais o preenchimento dessas lacunas.

Assim, e.g., em vez de editar Súmula regulamentando o tempo de sobreaviso no celular $^{659}$, mais adequado seria permitir que cada categoria discipline a

Trabalho, podendo-se dizer "que nenhum outro ramo do Direito vive tão próximo das manifestações econômicas como esse" (MORAES Filho, Evaristo de; e, MORAES, Antonio Carlos Flores de. Introdução ao Direito do Trabalho... Op. Cit., p. 211).

${ }^{656}$ SuPIOT, Alain; et al.. Transformações do trabalho e futuro do Direito do Trabalho na Europa. Coimbra: Coimbra, 2003, p. 152.

${ }^{657}$ Isso sem falar no efeito transverso dos excessos da "regulamentação" jurisprudencial. Veja-se, por exemplo, a situação em que hoje se encontra a tutela ao trabalho da mulher: depois de uma retração da proteção, ocorrida a partir da década de 1990 (diante do art. $5^{\circ}$, I, da CF/88 e da equiparação entre sexos), hoje o Tribunal Superior do Trabalho retoma o intento protecionista ao legitimar o intervalo de 15 minutos antes da jornada extraordinária (art. 384, CLT) e ampliar as hipóteses de estabilidade gestacional (e.g., no contrato a prazo - S. 244, III, TST). Tais proteções, entretanto, podem gerar maior discriminação ao trabalho feminino, na medida em que ampliam os custos da empresa que optar por referida espécie de mão de obra.

${ }^{658}$ Como, por exemplo, ocorreu com a Lei $12.551 / 11$, que regulamentou o teletrabalho em terras pátrias (Como realizar a fiscalização do trabalhador que presta serviços em domicílio?; Quais os critérios para aferição da subordinação nessa espécie de prestação de serviços?; etc.), e com a Lei 12.506/11, que regulamentou o aviso prévio proporcional (A proporcionalidade vale também para o aviso dado pelo empregado no caso de demissão?; Como fica a redução da jornada no aviso proporcional?; etc.).

${ }^{659}$ Faz-se menção, aqui, à Súmula 428 do TST: "SOBREAVISO APLICAÇÃO ANALÓGICA DO ART. 244, $\S 2^{\circ}$ DA CLT. I - O uso de instrumentos telemáticos ou informatizados fornecidos pela empresa ao empregado, por si só, não caracteriza o regime de sobreaviso; II - Considera-se em sobreaviso o empregado que, à distância e submetido a controle patronal por instrumentos telemáticos ou informatizados, permanecer em regime de plantão ou equivalente, aguardando a qualquer momento o chamado para o serviço durante o período de descanso". 
utilização de referido instrumento conforme sua necessidade concreta ${ }^{660}$; melhor do que assegurar ultratividade às cláusulas normativas ${ }^{661}$, seria respeitar sua duração pactuada pelas partes; etc.

Ainda pensando nos vazios da lei, por que não, também, legitimar a negociação coletiva a disciplinar a terceirização? A parassubordinação? A pejotização? Será que vale a pena, ao sindicato, manter visão combativa em relação a essas novas formas de trabalho? Não seria melhor auxiliar em sua regulamentação e, assim, evitar acordos unilaterais entre empregado e empregador - em manifesta precarização da relação laboral?

Ademais, importante papel poderia ser atribuído à negociação coletiva na regulamentação de profissões especiais.

A atuação dos sindicatos nesse sentido já vinha salientada no relatório da Comissão de Modernização das Relações de Trabalho, apresentado em $1994^{662}$, segundo o qual a regulamentação de categorias especiais pela via legal acabou favorecendo algumas em detrimento de outras, "na conformidade da força política de que dispunham para alcançar esse objetivo". Sabe-se, por outro lado, que o Estado não tem condições de elaborar uma lei para cada profissão, mas não é adequado que algumas profissões tenham regulamento específico e outras não.

Por isso, o Anteprojeto apresentado pela Comissão propunha que os direitos já assegurados às categorias especiais fossem mantidos, mas não pela via legal, e sim em instrumentos coletivos de âmbito nacional. Novos direitos, porém, somente poderiam ser positivados pela negociação coletiva, abstendo-se o legislador de disciplinálos.

Entende-se que a proposta mostra-se de todo acertada nesse aspecto, pois atribui à negociação coletiva a competência de regulamentar direitos específicos de categorias também específicas. Corroborando-se esse entendimento, recordem-se os

\footnotetext{
${ }^{660}$ Pense-se, por exemplo, nos empregados que trabalhem com sistemas de computação em bancos, e permanecem de plantão, por meio de instrumentos telemáticos, praticamente durante 24 horas por dia. Os elevados custos do período de sobreaviso fazem com que as empresas, simplesmente, abstenham-se de pagar referidas horas. Por que não permitir à negociação coletiva, assim, a fixação de escalas de compensação, ou remuneração adicional fixa para todo o período de sobreaviso?

${ }^{661}$ Faz-se menção, aqui, à Súmula 277 do TST: Súmula no 277 do TST: "CONVENÇÃo COLETIVA DE TRABALHO OU ACORDO COLETIVO DE TRABALHO. EFICÁCIA. ULTRATIVIDADE. As cláusulas normativas dos acordos coletivos ou convenções coletivas integram os contratos individuais de trabalho e somente poderão ser modificadas ou suprimidas mediante negociação coletiva de trabalho".

${ }^{662}$ Cf. supra, capítulo 5, item 5.3.
} 
ensinamentos de Amauri Mascaro Nascimento, para quem a negociação, por ser específica, para segmentos menores, "permite a autorregulamentação de detalhes que a lei, norma de ordem geral, para toda a sociedade, não pode nem deve reger". 663

Como decorrência benéfica desse processo, aliás, é bastante provável que as pressões exercidas pelas categorias especiais ensejem o próprio fortalecimento dos sindicatos, na medida em que estes se sentirão motivados a buscar novos direitos a seus representados.

Em síntese: já em 1962, afirmava Armand Kayser que "la forma principale del diritto autonomo del lavoro, cioè il contratto collettivo, servirà perfino da meccanismo pilota nel diritto economico in fase di evoluzione" ${ }^{664}$ Ao se atribuírem novas funções aos sindicatos, portanto, estar-se-á reconhecendo seu objetivo de preservação do equilíbrio dos custos sociais por meio da negociação coletiva - em feliz expressão de Amauri Mascaro Nascimento. ${ }^{665}$

\section{d) A flexibilização, pela negociação coletiva, deve ser pontual e contar com expressa autorização legal}

É nítida a necessidade de reforma da legislação trabalhista, diante das realidades sociais e econômicas do mundo do trabalho contemporâneo.

Não é adequada, porém, a flexibilização operada de cima para baixo, ou seja, imposta pelo legislador. Com efeito, além do caráter extremamente impopular da redução de direitos pela via legal ${ }^{666}$, sabe-se que seu procedimento não se reveste do dinamismo necessário para acompanhar as transformações do mercado ${ }^{667}$ : se o processo legislativo, de uma forma geral, já carece de celeridade, aquele que envolve lei flexibilizadora é ainda mais lento, por esbarrar em interesses políticos e sociais naturalmente divergentes.

\footnotetext{
${ }^{663}$ Nascimento, Amauri Mascaro. Compêndio de Direito Sindical... Op. Cit., p. 448.

664 "a forma principal do direito autônomo do trabalho, isto é, o contrato coletivo, servirá como mecanismo piloto no direito econômico em fase de evolução" - tradução livre (KAYSER, Armand. Le fonti del diritto del lavoro nel diritto dei paesi membri della comunità - Rapporto ricapitolativo... Op. Cit., p. 11).

${ }^{665}$ Nascimento, Amauri Mascaro. Compêndio de Direito Sindical... Op. Cit., p. 487.

${ }^{666}$ Veja-se, nesse sentido, a já mencionada experiência com o Fundo de Garantia do Tempo de Serviço FGTS - cf. supra, capítulo 5, item 5.2.

${ }^{667}$ Bem ressaltaram os membros da Comissão de Modernização da Legislação do Trabalho (Cf. supra, capítulo 5, item 5.3) que não é adequada a revisão da CLT, já que uma consolidação de leis, por definição, não se reforma; também se rechaça a ideia de uma codificação, na medida em que esta tende a ser rígida e pouco maleável às constantes adaptações sociais.
} 
É preciso, assim, atender ao comando constitucional de flexibilização de direitos pelos próprios interlocutores sociais (art. $7^{\text {o }}$, incisos VI, XIII, XIV e XXVI, $\mathrm{CF} / 88$ ), desde que haja expressa autorização legal para tanto. Combina-se, dessa forma, a atuação do legislador (que estabelece parâmetros e limites para a flexibilização) e das partes sociais (que procedem à adaptação legal ao caso concreto).

Defende-se, portanto, reforma na legislação trabalhista, para:

(i) Atribuírem-se maiores poderes à negociação coletiva, permitindo que esta disponha livremente sobre determinadas matérias (ainda que alterando a legislação in peius);

(ii) Especificarem-se quais matérias podem ou não ser objeto de livre negociação pelas partes.

Contudo, entende-se que a reforma em tela não poderia ser levada a cabo por simples alteração do art. 618 da $\mathrm{CLT}^{668}$, do art. $611^{669}$ ou do art. 468 , todos do mesmo diploma legal, ou mesmo pela positivação de "Estatuto" específico sobre o tema. ${ }^{670}$ Ao contrário, espelhando-se no direito espanhol ${ }^{671}$, melhor seria a alteração pontual de determinados artigos da CLT e legislação trabalhista esparsa, os quais passariam a prever a supletividade da lei em relação à negociação coletiva.

Com efeito, o grande mérito do modelo de despositivização adotado na Espanha é a precisão: ao se determinarem quais artigos do Estatuto de los Trabajadores podem ser alterados in peius pela negociação, confere-se segurança jurídica ao alcance da regra da supletividade. Ou seja: para saber se um determinado direito pode ou não ser alterado pela negociação coletiva, basta ler o(s) artigo(s) do Estatuto a ele referente(s). ${ }^{672}$

É o que já ocorre, aliás, no ordenamento brasileiro. Como visto, a Constituição de 1988 especifica, pontualmente, os direitos que admitem derrogação in peius, por meio da consagração da expressão "salvo negociação coletiva" (ou similar) no próprio artigo que prevê tais direitos. O ideal é que referida fórmula seja estendida a outros

\footnotetext{
${ }^{668}$ Como pretendido pelo Projeto de Lei no $5.483 / 01$ (cf. supra, capítulo 5, item 5.3)

${ }^{669}$ Como pretendido pelo Projeto de Lei no $4.193 / 12$ (cf. supra, capítulo 5, item 5.3)

${ }^{670}$ Como pretendido pelo Anteprojeto apresentado pela Comissão para Modernização das Relações de Trabalho, em 1993 (cf. supra, capítulo 5, item 5.3).

${ }^{671}$ Cf. supra, capítulo 4, item 4.3.2

${ }^{672}$ Veja-se que o modelo português não goza da mesma precisão, na medida em que o rol de matérias inalteráveis in peius, constante do art. $3^{\circ}$, n. $^{\circ} 3$, mostra-se amplo e genérico (cf. supra, capítulo 4, item 4.3.1).
} 
dispositivos legais, envolvendo as matérias a seguir elencadas. ${ }^{673}$

A simples previsão de que a negociação coletiva prevalece, em regra, sobre a lei (tal qual pretendiam muitos dos projetos de reforma da legislação trabalhista, como o Projeto de Lei $\left.n^{0} 5.483 / 01\right)$ é deveras ampla, e pode ensejar indesejável flexibilização, pela negociação coletiva, de direitos absolutamente indisponíveis pelo trabalhador. Ainda que se delimitem matérias infensas à negociação, a precisa determinação de tais matérias é de difícil operacionalização: como especificar, por exemplo, quais seriam as "normas de segurança e saúde do trabalho" (cuja derrogação era proibida pelo Projeto $\left.\mathrm{n}^{\mathrm{o}} 5.483 / 01\right)$ ? Estariam as férias inseridas em tais normas? $\mathrm{E}$ os intervalos intra e interjornada? E o descanso semanal remunerado?

Assim, a alteração pontual de dispositivos da CLT - para inserir a fórmula "salvo previsão em acordo coletivo de trabalho" - evitaria essas dúvidas, na medida em que os limites da negociação encontrar-se-iam devidamente especificados.

\section{e) É preciso trabalhar com o modelo sindical vigente, independentemente de reforma}

Como se viu ${ }^{674}$, a grande maioria das tentativas de implementação do modelo negociado em âmbito nacional esbarrou no argumento de que, primeiramente, seria necessário reformar a legislação sindical para, só depois, alterar a dinâmica da negociação coletiva.

Por certo, imperiosa se faz profunda reforma no modelo sindical brasileiro, ainda apegado a resquícios autoritários e corporativistas. Porém, sabe-se que aludida reforma, por envolver dissidentes interesses políticos e econômicos, ainda tende a alongar-se por muitos anos.

Por isso, para implementar o modelo de prevalência da negociação coletiva, é preciso trabalhar com o que se tem hoje no Brasil: um sistema de unicidade, com reduzidas taxas de sindicalização, sindicatos financiados pela contribuição compulsória e resistência de negociação pela parte patronal (especialmente diante da regra

\footnotetext{
${ }^{673} \mathrm{Cf}$. infra, item 6.3.2.

${ }^{674}$ Cf. capítulo 5, item 5.3
} 
da ultratividade das cláusulas normativas).

Nesse ponto, entende-se que a proposta dos metalúrgicos do $\mathrm{ABC}^{675}$, de 2012, é irretocável.

Com efeito, ciente das debilidades que atingem os entes sindicais pátrios - e, também, do longo caminho que a reforma do Direito Coletivo do Trabalho ainda há de trilhar -, a proposta apresenta a seguinte solução: apenas poderão ser celebrados acordos específicos por empresa e sob a responsabilidade do sindicato efetivamente representativo nessa empresa. ${ }^{676}$

Inicialmente, ao estabelecer que os acordos específicos terão abrangência restrita à empresa celebrante, o Anteprojeto do $\mathrm{ABC}$ assegura que a negociação in peius apenas atingirá as empresas que querem flexibilizar direito, forçando-as a buscar o sindicato quando pretenderem modular condições de trabalho. Evita-se, dessa maneira, que empregadores oportunistas valham-se da redução de direitos prevista em convenções de nível municipal, estadual ou nacional, mesmo sem necessitarem de tal redução.

Ademais, a previsão de celebração de acordos específicos tem o efeito de promover maior aproximação entre empresa e sindicato, na medida em que aquela dependerá deste quando desejar rever os direitos aplicáveis a seus empregados. Ainda, cria a consciência, no sindicato, de que é necessária a descentralização dos sistemas de negociação, ou seja, a negociação feita para a grande empresa não pode ser igual à feita para a pequena ou média, distintas que são suas realidades econômicas. ${ }^{677}$

De outra parte, com a regra de que apenas o sindicato efetivamente representativo na empresa poderá negociar direitos in peius, evita-se a atuação de sindicatos débeis, com reduzido poder de pressão, na modulação de direitos consolidados. $\mathrm{Na}$ ausência de sistema de pluralidade sindical ${ }^{678}$, que permitiria à própria lei criar critérios

\footnotetext{
${ }^{675}$ Cf. capítulo 5, item 5.3

${ }^{676}$ Como visto, a representatividade será aferida por: a) obtenção de habilitação junto ao Ministério do Trabalho e Emprego, fornecida somente se instalado em uma ou mais empresas de sua base de representação o Comitê Sindical de Empresa, composto por no mínimo dois e no máximo 32 membros; b) índice mínimo de sindicalização de 50\% mais 1 do total dos trabalhadores da empresa.

${ }^{677} \mathrm{O}$ que, aliás, já é reconhecido de forma tímida pela legislação brasileira, especificamente com relação às horas in itinere: o art. $58, \S 3^{\circ}$, da CLT permite a fixação de estimativa do tempo de deslocamento para o trabalho, por negociação coletiva, apenas às micro e pequenas empresas, ciente das dificuldades que estas enfrentariam se tivessem de controlar as horas in itinere diariamente.

${ }^{678}$ A doutrina majoritária afirma que a representatividade sindical pressupõe plena liberdade e pluralidade sindical: apenas em um regime no qual as próprias partes sociais são aptas a livremente se organizar, pode
} 
para aferir a representatividade do sindicato em âmbito nacional ${ }^{679}$, são necessárias regras específicas para determinar essa representatividade no interior do local de trabalho - como o faz o Anteprojeto do $\mathrm{ABC}$, ao estabelecer requisitos formais que devem ser preenchidos pelo sindicato interessado em negociar direitos in peius.

É certo que, por outro lado, ao prever requisitos tão severos para aferição da representatividade do sindicato na empresa (especialmente o índice mínimo de sindicalização), o projeto deixa de fora de sua abrangência sindicatos bem-intencionados, porém não aceitos pelos trabalhadores. Tal fato, entretanto, pode levar a efeito positivo transverso: o fortalecimento do próprio sindicato, na medida em que este, buscando atingir o índice de filiação exigido, intensificará sua atuação para aproximar-se dos trabalhadores e ganhar sua confiança.

Em síntese: a adoção dos critérios de representatividade propostos pelo Sindicato dos Metalúrgicos do ABC tende a fortalecer os sindicatos e a atividade negocial no Brasil - o que, em última análise, poderá até mesmo acelerar a própria reforma sindical, já que sindicatos fortes, notadamente, lutam pela instalação da plena liberdade sindical em seu âmbito de atuação. ${ }^{680}$

determinado sindicato afirmar-se como o mais representativo (MASsonI, Túlio de Oliveira. Representatividade Sindical. São Paulo: LTr, 2007, p. 108).

${ }^{679} \mathrm{O}$ conceito de representatividade sindical foi, originalmente, adotado na Itália, onde se atribui o título de "sindacato maggiormente rappresentativo" apenas à entidade que demonstre representatividade específica na relação com a empresa, a partir da celebração de contratos coletivos de qualquer nível, ainda que empresarial (art. 19 do Statuto dei Lavoratori). A tais sindicatos - e apenas a eles - a legislação confere os denominados "direitos de promoção e sustento" da organização sindical, como o exercício do direito de assembleia e de celebração de contratos coletivos (Galantino, Luisa. Diritto Sindicale... Op. Cit., pp. 33-34). Conforme ressalta Antonio Vallebona, a concessão do título de "sindacato maggiormente rappresentativo" demanda efetiva participação do sindicato na negociação coletiva, e não mera ficção instituída pelo legislador (VALleBOnA, Antonio. Istituzioni di diritto del lavoro - Il diritto sindacale. $6^{a}$ ed.. Padova: CEDAM, 2008, pp. 105-106). Também na Espanha, a Ley Orgánica de Libertad Sindical (LOLS) adota o conceito de representatividade para atribuir direitos promocionais às entidades sindicais. Segundo referida Lei, são critérios para a concessão de tal atributo ao sindicato: a) a porcentagem de representantes do sindicato atuantes na empresa e b) a adesão de um sindicato a outro que já seja considerado mais representativo (denominada "representatividade por irradiação"). Enquanto o primeiro critério, no entender da doutrina, efetivamente reflete a capacidade de defesa de interesses profissionais pelo sindicato, o segundo é falho, por se basear em mero formalismo legal, independentemente da existência de efetiva representação (CORREA CARRASCO, Manuel. Convenios e Acuerdos Coletctivos de Trabajo. Pamplona: Editorial Aranzadi, 1997, pp. 76-77).

${ }^{680}$ Nesse sentido, a lição de Arion Sayão Romita: "Queimar etapas, em temas de natureza social, por vezes encarna providência salutar. Desejável seria - é óbvio - que a ordem natural das coisas fosse observada: primeiro a reforma do sistema sindical, depois a liberdade de negociação, como consequência natural. Tal desiderato, contudo, encontra óbice intransponível na resistência oposta pelos atores cujos interesses imediatos serão afetados pela reforma. A adoção da medida preconizada pelo projeto contribuirá, sem dúvida, para acelerar a reforma, pois deixará evidente o atraso exibido pelo sindicalismo oficial" (ROMITA, Arion Sayão. O Princípio da Proteção em Xeque... Op. Cit.) 


\section{f) Apregoar a fraqueza generalizada dos sindicatos é contribuir para seu ainda maior enfraquecimento}

Para a plena instalação do modelo negociado no Brasil, é preciso abandonar alguns mitos arraigados na cultura trabalhista brasileira. O primeiro deles é o de que todos os sindicatos são fracos e, se não apresentam sequer condições de melhorar os direitos dos trabalhadores, não estariam aptos a reduzi-los diante de necessidades empresariais.

Os sindicatos não são tão fracos assim. Conforme bem ressalta Davi Furtado Meirelles, no período anterior às greves do ABC Paulista, iniciadas em 1978, o processo de negociação coletiva era precário e a legislação corporativista da CLT transformava os sindicatos em "meros clubes associativos, obrigados a conceder serviços assistencialistas e beneficio recreativos a toda categoria, deixando-os afastados das grandes questões econômicas, sociais e politicas". ${ }^{681}$

Porém, a situação se altera com a atuação do Sindicato dos Metalúrgicos de São Bernardo do Campo e de Diadema, da qual decorreu, por exemplo, o reconhecimento de Comissões de Fábrica - ainda presentes nas empresas da região. Ademais, com o movimento sindical da década de 1970, a negociação coletiva é realizada sempre que necessária a modulação de direitos trabalhistas, e não mais apenas anualmente, na data-base. Aliás, hoje em dia, a força de referido sindicato é tamanha que, como visto, dele partiu a proposta de criação do Acordo Coletivo de Trabalho com Propósito Específico.

É certo que a realidade do Sindicato dos Metalúrgicos é muito distinta de outras entidades sindicais, que ainda sofrem com a falta de representatividade e a dificuldade de conquistar direitos na mesa de negociações. Hélio Zylberstajn, entretanto, ressalta que tais problemas não são peculiares ao sindicato brasileiro, mas observados também nos países industrializados. ${ }^{682}$ Além do mais, segundo o mesmo autor, é preciso

681 MeIRELLES, Davi Furtado. Negociação coletiva no local de trabalho: a experiência dos metalúrgicos do ABC. Dissertação de mestrado apresentada à Pontifícia Universidade Católica de São Paulo (PUC-SP) em 2006, p. 222.

${ }^{682}$ ZYLBERSTAJN, Hélio. Os metalúrgicos do ABC: tentando construir o novo/velho sindicato no Brasil. Trabalho apresentado em dezembro de 2002 à FIPE - Fundação Instituto de Pesquisas Econômicas. Disponível online em http://www.fea.usp.br/feaecon//media/livros/file_298.pdf, p. 3. Nesse sentido, afirma 
reconhecer que o sindicato brasileiro vem ganhando espaço em outras esferas, especialmente na política, desde a eleição de um presidente que é o símbolo do sindicalismo. ${ }^{683}$

E não só na política os sindicatos vêm ganhando espaço. Sabe-se, por exemplo, que o adicional de periculosidade aos motoboys, inserido na CLT pela Lei $\mathrm{n}^{\mathrm{o}}$ $12.997 / 2014^{684}$, surgiu justamente diante das pressões dos sindicatos da categoria (o mesmo podendo ser dito sobre o adicional às atividades de segurança pessoal e patrimonial, previsto pela Lei $\mathrm{n}^{\mathrm{o}} 12.740 / 2012^{685}$ ). Além disso, inúmeras são as ações judiciais propostas diariamente pelos sindicatos do país ${ }^{686}$ no intuito de assegurar o cumprimento de direitos a seus representados. ${ }^{687}$ Por sinal, é mister recordar que,

Leôncio Martins Rodrigues que “em fins da década dos 80, em alguns países da Europa do Norte os sindicatos ainda conseguiam manter as mesmas taxas de filiação dos anos 70 e mesmo aumentar ligeiramente o número de filiados (...). Mas, desde então, à medida que o século XX chegava a seu término, foi se tornando cada vez mais claro que as dificuldades enfrentadas pelo sindicalismo não eram conjunturais e nem específicas de alguns países, e fatores estruturais mais duradouros e profundos minavam a força de uma das instituições mais características e importantes das democracias capitalistas do Ocidente" (RoDRIGUES, Leôncio Martins. Destino do Sindicalismo. Rio de Janeiro: Centro Edelstein de Pesquisas Sociais, 2009, p. $1)$.

${ }^{683}$ ZYLBERSTAJN, Hélio. Os metalúrgicos do ABC: tentando construir o novo/velho sindicato no Brasil... Op. Cit., p. 4.

${ }^{684}$ Art. 193, §4 $4^{\circ}$ CLT: "São também consideradas perigosas as atividades de trabalhador em motocicleta".

685 Art. 193, CLT: "São consideradas atividades ou operações perigosas, na forma da regulamentação aprovada pelo Ministério do Trabalho e Emprego, aquelas que, por sua natureza ou métodos de trabalho, impliquem risco acentuado em virtude de exposição permanente do trabalhador a:

(...)

II - roubos ou outras espécies de violência física nas atividades profissionais de segurança pessoal ou patrimonial".

${ }^{686} \mathrm{O}$ que faz recordar o voto de confiança dado pelo TST aos sindicatos ao cancelar a Súmula 310 e conferirlhes ampla legitimidade para ajuizamento de ações enquanto substitutos processuais - mais uma prova de que os sindicatos vêm experimentando fortalecimento de sua atuação nos últimos anos.

${ }^{687}$ Emblemáticos, nesse sentido, os recentes casos envolvendo dispensa em massa de trabalhadores. Recordese, por exemplo, o caso da EMBRAER, que, em fevereiro de 2009, dispensou cerca de 4.200 empregados, ensejando a propositura de dissídio coletivo pelo Sindicato dos Metalúrgicos de São José dos Campos e Região junto ao Tribunal Regional do Trabalho da $15^{\mathrm{a}}$ Região. Em Recurso Ordinário julgado pelo Tribunal Superior do Trabalho, este entendeu que a dispensa em massa era ilegal, pois deveria ser precedida de negociação com o sindicato (TST - ED-RODC-30900-12.2009.5.15.0000, publicação em 04/09/2009). Desde então, referido entendimento vem sendo aplicado pelo TST, como se extrai de recente caso envolvendo o encerramento das atividades da empresa Novelis do Brasil na planta de Aratu-BA: "DISSÍDIO COLETIVO DE NATUREZA JURÍDICA. DISPENSA COLETIVA. ENCERRAMENTO DA UNIDADE FABRIL. NEGOCIAÇÃO COLETIVA. 1. Ao interpretar o sistema constitucional vigente, como também as Convenções da OIT, firmou-se a jurisprudência desta Seção de Dissídios Coletivos no sentido de que a dispensa coletiva não constitui mero direito potestativo do empregador, uma vez que, para sua ocorrência e a definição de seus termos, tem de ser objeto de negociação com o correspondente sindicato de trabalhadores. 2. Na hipótese vertente, a empresa suscitada encerrou suas atividades no município de Aratu-BA, procedendo à dispensa de todos os empregados dessa unidade industrial, alegando questões de estratégia empresarial e redução dos custos de produção. 3. Nesse contexto, a negociação coletiva prévia com a entidade sindical dos trabalhadores fazia-se ainda mais necessária, tendo em vista que não se tratava de mera redução de pessoal, mas de dispensa da totalidade dos empregados do estabelecimento, com consequências mais graves para os trabalhadores desempregados. 4. Impõe-se, portanto, a manutenção da decisão recorrida que declarou a ineficácia da dispensa coletiva, e suas consequências jurídicas no âmbito das relações trabalhistas dos 
sobretudo a partir de 2004, a atuação judicial do sindicato ampliou-se drasticamente, com a positivação constitucional da necessidade de esgotamento das vias negociais para propositura de dissídios coletivos nos tribunais. ${ }^{688}$

Ainda, consoante já salientado ${ }^{689}$, todo o histórico flexibilizador da legislação trabalhista brasileira veio acompanhado do aumento das atribuições dos sindicatos - os quais foram sendo paulatinamente legitimados, pela lei, a negociar redução de salários, compensação de jornada, instituição de planos de participação nos lucros ou resultados, suspensão do contrato de trabalho, etc.

Por óbvio, o sindicalismo brasileiro ainda tem muito a evoluir. Porém, a negativa de concessão de maiores direitos ao sindicato, sob o simples argumento de que este é fraco e não tem efetivas condições de negociar condições de trabalho, constitui óbice a referida evolução. De fato, como ressalta Amauri Mascaro Nascimento, "sindicato e negociação coletiva (...) compõem um binômio, de maneira que as modificações no modo de conceber o sindicato refletem diretamente sobre a forma de compreender a negociação coletiva". 690

\section{g) É preciso superar a presunção de fraude}

De nada adianta conferir poderes às partes sociais se ainda prevalecem, no Brasil, a presunção da fraude generalizada e a política da "desconfiança”.

Atualmente, os órgãos de tutela do trabalho (ou seja, Justiça do Trabalho, Ministério do Trabalho e Emprego e Ministério Público do Trabalho) e os próprios sindicatos tendem a interpretar com severas restrições qualquer pretensão, por parte da empresa, de inovar na regulamentação de condições de trabalho; desconfia-se de condutas que não se amoldem, perfeitamente, aos padrões tradicionais da CLT, presumindo-se serem fraudulentas.

empregados envolvidos. Recurso ordinário a que se nega provimento". (TST - RO - 6-61.2011.5.05.0000, SDC, Relator Walmir Oliveira da Costa, Publicação 22/02/2013)

${ }^{688}$ Está-se fazendo referência à nova redação dos parágrafos $\S 1^{\circ}$ e $2^{\circ}$ do art. 114 , da $\mathrm{CF} / 88$, atribuída pela EC 45/2004 (Reforma do Judiciário). Aliás, conforme bem ressalta Pedro Paulo Teixeira Manus, a Constituição, de uma forma geral, manifestou clara preocupação em "elevar o sindicato a uma posição que permite interferir, realmente, nas relações entre patrão e empregado" (MANUS, Pedro Paulo Teixeira. Direito do

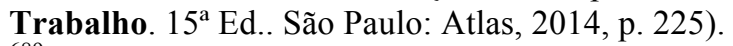

${ }^{689}$ Cf. supra, capítulo 5, item 5.2.

${ }^{690}$ NascimenTO, Amauri Mascaro. Compêndio de Direito Sindical... Op. Cit., p. 448. 
Por certo, se a inovação é feita no âmbito individual (i.e., entre empregado e empregador, diretamente), é natural - e até salutar - que haja certa desconfiança, já que o permanente estado presumido de coação em que o empregado se encontra em relação ao seu empregador justifica a indisponibilidade de direitos e a inalterabilidade contratual lesiva. Porém, no âmbito coletivo, a aplicação de referidos princípios é mitigada, pois o sindicato supre a hipossuficiência do empregado na negociação de condições de trabalho.

Por isso, o sindicato deve ver a empresa com bons olhos quando esta o chama a negociar direitos - eis que, se não se tratasse de empresa idônea, efetuaria "flexibilização" de forma unilateral, diretamente com o empregado. Assim, antes de rechaçar de plano sua proposta, sob a simples desconfiança de fraude, deve analisá-la, para se munir de elementos a serem levados à mesa de negociação.

Nesse sentido, conforme Amauri Mascaro Nascimento, diante das modificações sofridas pelo mercado de trabalho, o sindicato tem duas posições a adotar: a que rejeita, de plano, toda e qualquer simplificação da legislação trabalhista, sob a presunção de solapamento dos direitos dos trabalhadores, ou a que, "despindo-se de preconceitos, aceite reformas fundadas na compreensão de que a atual legislação pode voltar-se contra o trabalho e o sindicato, dependendo do modo como for interpretada ou aplicada". 691

O mesmo posicionamento deve ser adotado pelo Ministério Público do Trabalho. José Luciano de Castilho Pereira critica a intensa atuação desse órgão no ajuizamento de ações anulatórias de cláusulas convencionais, mesmo tendo a própria Constituição reconhecido plena autonomia às convenções e acordos coletivos de trabalho, e em manifesta violação ao art. $2^{\circ}$ da Convenção 98 da OIT, ratificada pelo Brasil. ${ }^{692}$

Com efeito, a presunção de desconfiança da flexibilização de direitos pela negociação coletiva também atinge os membros do Parquet, que vêm questionando cláusulas perfeitamente válidas de acordos e convenções, só porque implicam redução de direitos ao trabalhador. Nesse sentido, em breve pesquisa jurisprudencial, encontram-se ações anulatórias de cláusula que prevê a concessão de cesta básica apenas para o

\footnotetext{
${ }^{691}$ NASCIMENTO, Amauri Mascaro. Compêndio de Direito Sindical. $6^{\text {a }}$ edição. São Paulo: Ltr, 2011, p. 111. ${ }^{692}$ Pereira, José Luciano de Castilho. O sindicato e sua força na negociação coletiva... Op. Cit., p. 29. Segundo o autor, "tudo isto revela de um lado a voracidade quase escravocrata do capital e, de outro, a incapacidade sindical de exercer o papel que lhe foi reservado pela Constituição na defesa dos trabalhadores".
} 
empregado assíduo ${ }^{693}$, que determina a comunicação prévia de faltas ${ }^{694}$, que disciplina descontos salariais no caso de prejuízos causados com culpa pelo empregado ${ }^{695}$, etc.

Com referida atuação ministerial - amparada pela Justiça do Trabalho -, por óbvio, o sindicato enfraquece-se cada vez mais. É preciso, assim, superar a cultura da fraude e da desconfiança, e atribuir ao sindicato a consciência de que ele está apto a promover as necessárias adaptações da legislação trabalhista ao caso concreto. Nesse sentido, bem ressalta Cássio Mesquita Barros que "o desenvolvimento não se realiza por lei nem através de decisões judiciais. Na economia, na política e na cultura se desenvolvem a inteligência, o esforço e a vontade dos seres humanos". 696

693 AÇÃo ANUlatória. Cláusula CONVEncional. CESTA básica Para O EMPREGADO ASSÍDUO. VALIDADE. A cláusula coletiva de trabalho que estipula o benefício da cesta básica para o empregado que apresentar até um atestado médico ao mês, em contrapartida à implantação do Banco de Horas e com vistas a retribuir o empregado assíduo durante 220 horas trabalhadas, reflete autêntica transação oriunda da vontade autônoma privada, com respaldo no art. $7^{\circ}$, XXIV, da CF. Ação admitida e julgada improcedente, por unanimidade. (TRT-24 - AACC: 149008220095240 MS 14900-82.2009.5.24.0, Relator: MARCIO V. THIBAU DE ALMEIDA, Data de Julgamento: 15/10/2009, Data de Publicação: DO/MS N 658 de 06/11/2009, pag.)

${ }^{694}$ AÇÃO ANULATÓRIA (...) 2 - CLÁUSUla DE ABONO DE FALTAS. Para atender a disciplina empresarial mínima e indispensável, é razoável a exigência de que o trabalhador interessado proponha faltar ao trabalho para exames escolares, por escrito e com prazo mínimo de antecedência (TRT-7 - AA: 1341005720095070000 CE 0134100-5720095070000, Relator: CLAUDIO SOARES PIRES, Data de Julgamento: 20/10/2009, PLENO DO TRIBUNAL, Data de Publicação: 17/11/2009 DEJT).

${ }_{695}$ AÇÃO ANULATÓRIA DE CLÁUSUlas CONVENCIONAIS. CLÁUSULA 11 a , ALÍNEA A. INEXISTENCIA DE RESTRIÇÃO A DIREITO TRABALHISTA E PREJUÍZO AO TRABALHADOR. O dispositivo questionado, ao exigir do obreiro a comunicação prévia da falta ao empregador até dois úteis antes do dia da realização de exames escolares ou vestibulares, não afronta qualquer direito trabalhista. Não se trata de autorização patronal, mas de mera comunicação prévia ao empregador, com vistas à necessária ciência da falta do empregado inerente ao poder de gestão. ClÁUSUla 29a. AUTORIZAÇÃo de DESCONTO ACORDADA POR MEIO DE NORMA COLETIVA. POSSIBILIDADE. $O$ art. 462, da CLT, que contempla o princípio da intangibilidade salarial, é claro ao dispor que o empregador pode efetuar o desconto nos salários em caso de dano provocado pelo trabalhador desde que tenha sido acordado previamente pelas partes. Não há qualquer vedação a tal desconto em casos em que o ato lesivo praticado foi culposo, fruto de negligência, imprudência ou imperícia. Na situação em comento, houve uma autorização acordada por meio de norma coletiva, a qual substitui o ajuste por meio do contrato de trabalho individual. AÇÃO ANULATÓRIA DE CLÁUSULAS CONVENCIONAIS JULGADA IMPROCEDENTE. (TRT-7 - AA: 3476001220095070000 CE 0347600-1220095070000, Relator: MANOEL ARÍZIO EDUARDO DE CASTRO, Data de Julgamento: 09/03/2010, PLENO DO TRIBUNAL, Data de Publicação: 06/04/2010 DEJT)

${ }^{696}$ BARROS, Cássio Mesquita. Modernização da CLT à luz da realidade brasileira... Op. Cit., p. 112. 


\subsection{Limites}

\section{a) A negociação deve ser coletiva}

$\mathrm{Na}$ prevalência do negociado sobre o legislado, deve-se entender a expressão "negociado" como fruto da atuação coletiva dos sindicatos. Em outras palavras, a flexibilização de direitos não poderá ocorrer pela via individual, mas apenas quando o trabalhador estiver representado por sua entidade de classe.

Isso porque, conforme acima salientado, na esfera individual prevalecem os princípios da indisponibilidade de direitos e da inalterabilidade contratual lesiva. Conforme Américo Plá Rodriguez, na relação de emprego há "vício de consentimento presumido", pois, quando o trabalhador renuncia a direitos o faz por ignorância ou erro que vicia o ato. ${ }^{697}$ Poder-se-ia, também, afirmar que o empregado encontra-se em permanente estado presumido de coação perante seu empregador, na medida em que qualquer renúncia a direitos consolidados reflete sua posição de inferioridade econômica e a necessidade de manter seu emprego.

Por certo, algumas espécies de empregados não podem ser enquadradas na descrição acima, por força de seu elevado poder de negociação junto ao empregador. Está-se aludindo, aqui, sobretudo aos altos empregados - os quais, por força de seu elevado poder de gestão na empresa, não podem ser considerados verdadeiramente hipossuficientes e com vício de consentimento presumido.

Contudo, deixando de lado a discussão referente a tais empregados - a qual, certamente, mereceria estudo específico e aprofundado, que não cabe no presente trabalho -, para a grande massa dos trabalhadores, a flexibilização de direitos somente pode se operar pela via coletiva, considerando o sindicato enquanto legítimo detentor do interesse coletivo.

\section{b) Deve haver critérios formais para que o sindicato possa negociar}

Apenas reiterando o que acima já se expôs, diante da ausência de plena liberdade sindical no país, a flexibilização de direitos pela via negocial deve ser

${ }^{697}$ RodrigueZ, Américo Plá. Princípios do Direito do Trabalho... Op. Cit., pp. 61-62. 
acompanhada de precisos critérios formais a serem preenchidos pelo sindicato legitimado a efetuar a contratação in peius.

Retomando-se, assim, o Anteprojeto do Sindicato dos Metalúrgicos do $\mathrm{ABC}$, em matéria de aferição da representatividade sindical, o sindicato deverá:

a) Obter habilitação junto ao Ministério do Trabalho e Emprego, a qual apenas será fornecida se observados os requisitos a seguir. É importante ressaltar que referida habilitação não compromete a liberdade de criação de sindicatos constante do art. $8^{\circ}$, I, da CF/88, na medida em que não se está diante de autorização para funcionamento do sindicato, e sim de mero reconhecimento da capacidade negocial in peius, mediante acordos específicos. Em outras palavras: a negociação coletiva é assegurada a todo e qualquer sindicato, mas a capacidade de flexibilização de direitos somente será reconhecida àqueles detentores de habilitação do MTE;

b) Comprovar a instalação de Comitê Sindical de Empresa (CSE) em uma ou mais empresas de sua base de representação, composto por no mínimo dois e no máximo 32 membros. Defende-se, aqui, a transposição do modelo de representação interna criado pelo Sindicato dos Metalúrgicos do ABC para outras entidades sindicais; assim, caso o sindicato deseje negociar condições de trabalho diretamente com a empresa, deverá prever, em seu estatuto, a criação do CSE, para que este seja efetivamente instalado nas fábricas.

Nesse ponto, apresenta-se dificuldade de ordem prática envolvendo as micro e pequenas empresas, que dificilmente conseguirão formar os Comitês em seus estabelecimentos. Possível solução para o problema seria a criação de Comitê dentro do sindicato, ao qual as empresas poderiam aderir, mediante autorização expressa de seus empregados. Dessa forma, mesmo não havendo representação no interior da empresa, existiria "facção" mais específica do sindicato para defender os direitos também específicos de seus empregados.

c) Ter o Comitê Sindical reconhecido, pela empresa, como órgão de representação do sindicato profissional no local de trabalho (mediante acordo coletivo celebrado para este fim);

d) Apresentar índice mínimo de sindicalização de 50\% mais 1 do total dos trabalhadores da empresa que pretende negociar condições de trabalho. 
Ademais dos requisitos de ordem formal acima indicados, o acordo de flexibilização de direitos somente poderá ser aplicável no âmbito da empresa signatária. Rechaça-se, assim, a possibilidade de negociação in peius pela via da convenção coletiva pois, ainda que celebrada em âmbito municipal, envolve realidades muito distintas no que concerne às empresas por ela abrangidas.

A possibilidade de negociação in peius em âmbito superior ao empresarial é reconhecida pelos ordenamentos europeus, especialmente o português e o espanhol. ${ }^{698}$ Porém, entende-se indevida a transposição da experiência de tais países ao ordenamento brasileiro, eis que este - como antes salientado - ainda carece do efetivo pluralismo necessário à positivação legal de critérios de representatividade sindical.

\section{d) O acordo deverá especificar as contingências sociais e econômicas que determinaram sua celebração, e não poderá ser definitivo}

Além da delimitação territorial de sua abrangência, o acordo flexibilizador deverá precisar os motivos de sua celebração, bem como seu prazo de duração - o qual, em hipótese alguma, poderá ser indeterminado.

Inicialmente, as partes signatárias devem explicitar, no acordo, o porquê da derrogação de direitos - crise econômica, adaptação das condições de trabalho à realidade empresarial, etc. Na falta de explicitação, caberá aos órgãos de fiscalização do trabalho proceder à autuação da empresa celebrante (no caso do MTE) e à anulação do instrumento coletivo (no caso do MPT), eis que se deve presumir inexistente o motivo da alteração in peius de direitos consolidados.

Além do mais, consoante já previsto pelo ordenamento brasileiro ${ }^{699}$, a alteração nunca poderá ter caráter definitivo, vigorando apenas enquanto a modulação de direitos se fizer necessária. ${ }^{700}$

Já se rechaçou, em outro momento deste capítulo ${ }^{701}$, a flexibilização pela via legal, por conta da ausência de caráter democrático na sua operacionalização. Agora,

\footnotetext{
${ }^{698}$ Cf. supra, capítulo 4, item 4.3 .

${ }^{699}$ Está-se referindo, aqui, ao art. $614, \S 3^{\circ}$, da CLT, o qual prevê duração máxima de dois anos aos acordos e às convenções coletivas de trabalho (embora, como se sabe, tal dispositivo tenha sofrido forte golpe com a alteração da Súmula 277 do TST, que passou a consagrar a ultratividade de cláusulas normativas). Especificamente em matéria de flexibilização de direitos, é mister recordar, também, o art. $2^{\circ}$ da Lei ${ }^{\circ}$ $4.923 / 65$, o qual limita a redução salarial em virtude de crise econômica pelo prazo de 3 meses, prorrogável apenas se houver necessidade.

${ }^{700}$ Sempre respeitado o prazo máximo do art. $614, \S 3^{\circ}$, da CLT.
} 
some-se às críticas anteriores o fato de que toda flexibilização legal tende a gerar efeitos definitivos - os quais podem justificar-se no momento de sua realização, mas não necessariamente se mantêm indefinidamente.

Por isso, como bem ressalta Ives Gandra da Silva Martins Filho, embora alguns defendam que o ideal residiria em, simplesmente, revogar dispositivos da CLT que se mostrem inaplicáveis, tal procedimento seria perigoso, já que, por erro de avaliação e diante de meras situações conjunturais, poderiam acabar suprimidos, em definitivo, dispositivos importantes à proteção do trabalhador. ${ }^{702} \mathrm{O}$ melhor método, nesse sentido, consiste em ampliar o rol das matérias negociáveis, "uma vez que a redução de direitos seria tópica e temporária, podendo ser restabelecida a regra rígida ao final do período de vigência da norma coletiva". ${ }^{703}$

E, uma vez ampliado o rol de direitos adaptáveis pela contratação coletiva, caberá ao sindicato dosar o prazo de duração da alteração legal, diante da situação concreta experimentada em cada mesa de negociação.

\section{e) Deve haver delimitação das matérias negociáveis}

De todos os limites acima apresentados, talvez o mais importante - não contemplado pelo Anteprojeto do Sindicato dos Metalúrgicos do ABC, mas previsto na proposta da Comissão para Modernização da CLT e no Projeto de Lei n ${ }^{0}$ 5.483/01 repousa na delimitação de quais matérias poderiam ou não ser objeto de contratação coletiva in peius. Por tal razão, esse limite será objeto de tópico específico do presente capítulo, no qual se analisarão pontualmente alguns temas a serem - ou não - delegados à negociação direta entre as partes sociais.

\footnotetext{
${ }^{701}$ Cf. supra, item 6.1, tópico "d".

${ }^{702}$ MARTINS Filho, Ives Gandra da Silva. O bélico e o lúdico no direito e no processo... Op. Cit., p. 31.

${ }^{703}$ Martins Filho, Ives Gandra da Silva. O bélico e o lúdico no direito e no processo... Op. Cit., p. 31.
} 


\subsection{Matérias negociáveis}

Como já afirmado ${ }^{704}$, a realidade do ordenamento jurídico brasileiro impede que a negociação coletiva seja consagrada como regra geral para a instituição de direitos trabalhistas.

Por isso, com a devida vênia, rechaça-se o posicionamento de Amauri Mascaro Nascimento, o qual defende a regulamentação estatal somente de matérias relacionadas com tutela da personalidade, saúde, segurança, meio ambiente do trabalho, etc., delegando a disciplina das demais às próprias partes. ${ }^{705}$ No mesmo sentido, afasta-se a solução apresentada pela proposta da Comissão para Modernização da CLT e pelo Projeto de Lei $n^{0}$ 5.483/01: atribuir à negociação plena capacidade de alteração de direitos legais, somente delimitando quais matérias não poderiam ser por ela regulamentadas. ${ }^{706}$

Melhor seria, ao contrário, a instituição de regime em que se mantém a prevalência da legislação na regulamentação das condições de trabalho, mas se especifica, em artigos da CLT e de leis esparsas, quais dessas condições podem ser afastadas in peius pela negociação coletiva - na linha da experiência vivenciada pelo ordenamento espanhol. $^{707}$

\subsubsection{O que já é permitido}

Consoante já ressaltado, a própria Constituição de 1988 foi responsável pelo alargamento do espaço da negociação coletiva. ${ }^{708}$ A seguir, assim, apresentam-se as

\footnotetext{
${ }^{704}$ Cf. supra, item 6.1, tópico "d".

${ }^{705}$ Nascimento, Amauri Mascaro. Compêndio de Direito Sindical... Op. Cit., p. 421.

${ }^{706}$ De acordo com Cássio Mesquita Barros, com efeito, "embora o comportamento autônomo, que significa as partes estarem tomando para si, em maior medida, a responsabilidade de determinar as condições de trabalho, isto não quer dizer que se tenha implantado, no Brasil, um sistema totalmente voluntarista no qual o Estado pode desaparecer do campo das relações do trabalho. É preciso não esquecer que a lei da oferta e da procura exerceu no mercado de trabalho influência trágica". (BARRos, Cássio Mesquita. Modernização da CLT à luz da realidade brasileira... Op. Cit., p. 113).

${ }^{707}$ Cf. supra, capítulo 4, item 4.3.2

708 Ainda assim, segundo Arion Sayão Romita, “o constituinte de 1988 olvidou-se da lição de Portalis. O autor do Discours préliminaire, em 1804, assentou que 'as leis positivas não podem substituir inteiramente o uso da razão natural nos assuntos da vida. As necessidades da sociedade são tão variadas, a comunicação dos homens é tão ativa, seus interesses são tão multiplicados e suas relações tão extensas, que é impossível ao legislador a tudo prover'. E adiante: 'A tarefa da lei é fixar, em grandes linhas, as máximas gerais do direito, estabelecer princípios fecundos em consequências, e não descer ao pormenor das questões que podem surgir em cada matéria". O excesso de normatividade do Texto Fundamental de 1988 deve ser condenado". (Romita, Arion Sayão. O Princípio da Proteção em Xeque... Op. Cit.).
} 
principais matérias já reconhecidas, por lei ou pela jurisprudência, como diretamente afetas à negociação pelos próprios interlocutores sociais:

- Art. $7^{\mathbf{0}}, \mathbf{V I}, \mathbf{C F} / 88$ : redução de salário (hoje compreendida pela doutrina como envolvendo não apenas o salário-base, mas também as formas complementares de remuneração); ${ }^{709}$

- Art. 7 $^{\mathbf{0}}$ XIII, CF/88: compensação da jornada de trabalho;

- Art. $\mathbf{7}^{\mathbf{0}}$, XIV, CF/88: ampliação da jornada em turnos ininterruptos de revezamento;

- Art. 114, $\S^{\circ}, \mathbf{C F} / \mathbf{8 8}$ : reconhecimento da arbitragem para solução de conflitos trabalhistas;

- $\quad$ Art. 58, $\S^{\mathbf{0}}$, CLT: fixação das horas in itinere para micro e pequenas empresas;

- Art. 476-A, CLT: suspensão do contrato de trabalho para qualificação profissional do empregado;

- Lei $n^{\circ}$ 9601/98: estipulação de contratos com prazo determinado ademais daqueles já previstos pela CLT;

- Lei no 10101/00: regulamentação de plano de participação nos lucros ou resultados (bem como previsão de arbitragem no caso de conflitos envolvendo a PLR);

- Portaria MTE no 3296/86: substituição do fornecimento de creche pelo pagamento do "reembolso-creche";

- Portaria MTE no 373/11: admissibilidade de sistemas alternativos de controle de jornada, como o ponto por exceção;

- Súmula no 444 do TST: previsão da jornada 12 x 36;

- Súmula n 85, V, TST: negociação de banco de horas;

- Orientação Jurisprudencial no 323 da SDI1-TST: fixação de acordo de compensação de jornada no formado "semana espanhola";

- Orientação Jurisprudencial no 251 da SDI1-TST: previsão de critérios para descontos de cheques sem fundos recebidos por frentistas de postos de gasolina.

Embora manifesta a ampliação de competências delegadas à negociação coletiva, é certo que também foram verificados retrocessos nos últimos anos, especialmente na jurisprudência pátria. Assim, por exemplo, a possibilidade de fixação de

709 Nascimento, Amauri Mascaro. Limites da negociação coletiva na perspectiva de projeto de flexibilização da CLT... Op. Cit., p. 1420. 
adicional de periculosidade em percentual inferior ao legal, no caso de exposição intermitente ao risco, antes reconhecida à negociação, mas, em 2011, retirada de sua competência, com o cancelamento do item II da Súmula no 364 do TST; a modulação dos intervalos intrajornada, que passou por longo caminho até ser proibida pelo TST, em 2004, com a OJ-SDI1-342, hoje convertida na Súmula $n^{0} 437$, II $^{710}$; a proibição à previsão de compensação de jornada insalubre por meio da negociação coletiva, com o cancelamento da Súmula no 349 do TST; etc.

\subsubsection{Novas previsões}

Além das matérias acima elencadas, outras deveriam ser atribuídas à negociação coletiva, entre as quais se destacam:

\section{Normas sobre duração do trabalho}

As normas sobre duração do trabalho talvez sejam as que oferecem maior campo de atuação à negociação coletiva - eis que a própria Constituição já reconhece a possibilidade de sua modulação pelas partes sociais. ${ }^{711}$ Sem prejuízo de esgotar a matéria, assim, a seguir apresentam-se sugestões de temas cuja regulamentação poderia ser repassada à contratação coletiva, permitindo derrogações in peius da normativa legal:

a) Duração máxima da jornada de trabalho: na linha do que já preveem a Súmula $n^{\circ} 444$ do TST (sobre jornada 12 x 36) e a própria Constituição, no art. $7^{\circ}$, XVI (sobre turnos ininterruptos de revezamento), entende-se que a duração máxima do trabalho pode ser adaptada pela negociação coletiva, a depender da atividade desempenhada pelo empregado. Assim, por exemplo, nas atividades de tecnologia

\footnotetext{
${ }_{710}^{710}$ Após a revogação da Portaria MTE no 42/2007 pela Portaria nº 1095/10.

711 José Pastore entende que a maior importância da negociação coletiva, na matéria de jornada, é sua capacidade de adaptação da duração do trabalho a cada uma das categorias existentes. O autor afirma que, ao contrário do que comumente se crê, a redução da jornada - atualmente propalada por muitos sindicatos - ou mesmo o aumento do adicional de horas extras (como forma de vedar sua realização) não têm o condão de melhorar a empregabilidade. Aliás, é mais provável que as empresas adaptem seu horário ou introduzam novas tecnologias para não ter que fazer horas extras ou contratar excedentes. Isso porque os custos de contratação são muito elevados, e envolvem recrutamento, treinamento, compra de equipamentos, ampliação de espaço físico, etc. Assim é que, no caso de ampliação do adicional de horas extras, "o valor terá de ser estratosférico para compensar as despesas de contratação para atender a um pico de demanda, especialmente em empresas de pequeno porte". Assim é que o autor defende a redução da jornada não pela via legal, mas apenas por negociação coletiva - já que esta se baseia diretamente nos cálculos da empresa de todas essas variáveis (PASTORE, José. Redução de jornada gera emprego?... Op. Cit., pp. 99-100).
} 
da informação, em que, muitas vezes, é necessário trabalho ininterrupto por parte do empregado, poder-se-ia prever jornada superior a 8 horas, com escalas de revezamento; ou nas atividades de docência, em que a jornada máxima de 4 horas/aula consecutivas ou 6 intercaladas (art. 318, CLT), dependendo da natureza da instituição de ensino, impede a formalização de contrato de trabalho com o professor, proliferando formas de contratação alternativa, como pejotização, cooperativa, recibo de prestação de serviços autônomos, etc.;

b) Sobreaviso: a regulamentação das horas de sobreaviso também mereceria tratamento específico pela negociação coletiva, na medida em que deve considerar as peculiaridades de cada atividade. Com efeito, não é crível admitir que regulamentação concebida em 1943 para categoria específica de trabalhadores (i.e., os ferroviários) seja subsidiariamente aplicada aos atuais contratos de trabalho, marcados pela intensa dedicação do trabalhador à atividade empresarial. Também não se mostra adequada a disciplina da matéria pela via jurisprudencial - como fez o TST na Súmula $n^{\circ} 428$, recém alterada. Melhor seria atribuir às próprias partes sociais a determinação dos limites e da forma de remuneração do sobreaviso, atentando às particularidades da prestação de serviços;

c) Ponto por exceção: embora o próprio Ministério do Trabalho permita a adoção de métodos alternativos de controle da jornada (Portaria MTE $n^{\circ} 373 / 11$ ), sabe-se que estes ainda vêm sendo questionados pela jurisprudência. ${ }^{712}$ Porém, referidos sistemas de marcação de ponto - como, por exemplo, o ponto por exceção -,

\footnotetext{
${ }^{712}$ Nesse sentido: "RECURSO ORDINÁRIO. HORAS EXTRAS. MARCAÇÃO DE PONTO -POR EXCEÇÃO- NORMA COLETIVA INEFICAZ. RECURSO ORDINÁRIO. HORAS EXTRAS. MARCAÇÃO DE PONTO -POR EXCEÇÃO- NORMA COLETIVA INEFICAZ. RECURSO ORDINÁRIO. HORAS EXTRAS. MARCAÇÃO DE PONTO -POR EXCEÇÃO- NORMA COLETIVA INEFICAZ. RECURSO ORDINÁRIO. HORAS EXTRAS. MARCAÇÃO DE PONTO POR EXCEÇÃO-. NORMA COLETIVA INEFICAZ. SÚMULA no 14 DESTE EGRÉGIO TRIBUNAL. A obrigatoriedade de controle da jornada de trabalho é imperativo legal (CLT, artigo 74, $\S \S 1^{\circ}$ e $2^{\circ}$ ), sendo ineficaz, de pleno direito, a cláusula normativa que dispõe em sentido contrário". (TRT-1 - RO: 342004720095010072 RJ , Relator: Leonardo Pacheco, Data de Julgamento: 15/10/2013, Quinta Turma, Data de Publicação: 25-10-2013); “AGRAVO DE INSTRUMENTO. RECURSO DE REVISTA. REGISTRO DE PONTO POR EXCEÇÃO. VALIDADE. Correta a decisão regional que considerou inválida a forma de registro de ponto por exceção (registro apenas dos possíveis excessos, sem anotação dos limites diários da jornada), em virtude de contrariar o art. $74, \S 2^{\circ}$, da $\mathrm{CF}$, uma vez que formas que visem à simplificação do controle de jornada são distintas das que eliminam esse controle (que é a hipótese dos autos). Ressalte-se que o e. Tribunal Regional, analisando o conjunto probatório, entendeu pela invalidade do sistema de registro de ponto por exceção, ainda que autorizado por norma coletiva, ao verificar, além de tudo, que a inscrição das horas extras dependeria de aprovação do gerente ou outro superior, o que poderia ser discricionariamente obstado, causando prejuízos ao trabalhador. Assim sendo, inviável a admissibilidade do agravo de instrumento, porquanto conclusão diversa exigiria nova aferição do contexto probatório, procedimento inviável nesta esfera recursal, como elucida a Súmula 126 desta Corte. Agravo de instrumento a que se nega provimento". (TST - AIRR: 302400-56.2010.5.03.0000, Relator: Horácio Raymundo de Senna Pires, Data de Julgamento: 22/06/2011, $3^{\text {a }}$ Turma, Data de Publicação: DEJT 01/07/2011); etc.
} 
atendem às necessidades concretas da prestação de serviços e, por isso, deveriam ser privilegiados, em detrimento do rígido modelo imposto pelo art. $74, \S 2^{\circ}$, da CLT;

d) Cargos de confiança e trabalhadores externos: em vez de simplesmente afastar os ocupantes de cargos de confiança e trabalhadores externos do controle de jornada, a legislação deveria conferir a eles próprios a capacidade de regulamentar sua jornada, incluindo a disciplina dos intervalos, do sobreaviso, etc. (matérias que, ainda hoje, suscitam questionamentos doutrinários e jurisprudenciais);

e) Intervalos: retomando o disposto na revogada Portaria MTE $n^{\circ} 42$, de 2007, melhor seria atribuir à negociação coletiva a possibilidade de reduzir o intervalo intrajornada, diante de peculiaridades verificadas no caso concreto. A medida, aliás, mostrar-se-ia benéfica ao próprio trabalhador, vez que, com a redução dos intervalos, seu tempo de permanência na empresa também seria reduzido;

f) Trabalho noturno: seguindo a experiência espanhola sobre o tema ${ }^{713}$, seria adequado permitir à negociação coletiva a modulação do trabalho noturno, especificamente do que se compreende por "noite" e do respectivo adicional (flexibilização que se faria assaz necessária, por exemplo, para empresas que só funcionam à noite).

\section{Férias e Descanso Semanal Remunerado}

Com relação ao Descanso Semanal Remunerado (DSR) importante matéria a ser delegada à negociação coletiva é a preferência de seu gozo aos domingos.

Sabe-se que a determinação legal de que o DSR seja usufruído preferencialmente aos domingos remonta à Encíclica Rerum Novarum, a qual - baseandose no Antigo Testamento - consolidou que, no sétimo dia da semana, deveria ser assegurado repouso ao trabalhador, para que este pudesse cumprir suas obrigações religiosas. ${ }^{714}$ Porém, a moderna sociedade do trabalho exige que tal preferência ceda

\footnotetext{
${ }_{713}$ Cf. supra, capítulo 4, item 4.3.2.

714 "Daqui vem, como consequência, a necessidade do repouso festivo. Isto, porém, não quer dizer que se deve estar em ócio por mais largo espaço de tempo, e muito menos significa uma inacção total, como muitos desejam, e que é a fonte de vícios e ocasião de dissipação; mas um repouso consagrado à religião. Unido à religião, o repouso tira o homem dos trabalhos e das ocupações da vida ordinária para o chamar ao pensamento dos bens celestes e ao culto devido à Majestade divina. Eis aqui a principal natureza e fim do repouso festivo que Deus, com lei especial, prescreveu ao homem no Antigo Testamento, dizendo-lhe: 'Recorda-te de santificar o sábado'; e que ensinou com o Seu exemplo, quando no sétimo dia, depois de
} 
espaços às necessidades de funcionamento de determinadas atividades aos domingos e, até mesmo, às crenças de outras religiões que não se amoldam aos dogmas católicos.

Por isso, a disciplina do trabalho aos domingos deveria ser integralmente repassada à contratação coletiva, eliminando-se dispositivos legais obsoletos ${ }^{715}$ e pautados estritamente em convicções religiosas. ${ }^{716}$

No mesmo sentido, com relação às férias, algumas matérias poderiam ser delegadas à negociação, como, e.g.: a) o fracionamento das férias em períodos menores $\left.\left(\text { art. } 134, \S 1^{\circ}, \mathrm{CLT}\right)^{717} ; b\right)$ a revogação da proibição ao fracionamento de férias aos maiores de 50 anos (art. 134, $\S 2^{\circ}$, CLT); e c) a revogação da proibição à prestação de serviços a outro empregador, durante as férias (art. 138, CLT). ${ }^{718}$

\section{Normas envolvendo salário}

No que tange aos salários, entende-se que a própria norma do art. $7^{\circ}, \mathrm{VI}$, da $\mathrm{CF} / 88$, já permite ampla flexibilização, ao conferir à negociação coletiva atribuição que seria a menos benéfica possível ao trabalhador nessa matéria: a redução salarial. Portanto, aspectos como alteração da morfologia salarial (i.e., determinação de quais parcelas

criado o homem, repousou: "Repousou no sétimo dia de todas as Suas obras que tinha feito"' (texto integral disponível online em http://www.vatican.va/holy_father/leo_xiii/encyclicals/documents/hf_lxiii_enc_15051891_rerum-novarum_po.html).

${ }_{715}$ Como o art. 386 da CLT, segundo o qual, para as empregadas mulheres, "havendo trabalho aos domingos, será organizada uma escala de revezamento quinzenal, que favoreça o repouso dominical".

${ }^{716}$ Colacione-se, a respeito, decisão do Tribunal Superior do Trabalho que limitou os efeitos de convenção coletiva de trabalho que previa folga aos domingos apenas uma vez a cada sete semanas: "AGRAVO DE INSTRUMENTO EM RECURSO DE REVISTA. (...) 2. TRABALHO AOS DOMINGOS. O Regional entendeu que, mesmo que o instrumento coletivo adotado pela reclamada pudesse garantir a seus empregados a fruição de um repouso semanal remunerado, ao menos uma vez por mês, tal folga deveria coincidir com o domingo. Vê-se, por conseguinte, que a Corte a quo entendeu por restringir os limites e contornos da Convenção Coletiva de Trabalho de forma a adequá-los aos preceitos constitucionais e legais apontados. Nesse contexto não se verifica ofensa direta e literal do artigo $7^{\circ}$, XXVI, da Constituição Federal. Agravo de instrumento conhecido e não provido" (TST - AIRR: 9135920105090000 913-59.2010.5.09.0000, Relator: Dora Maria da Costa, Data de Julgamento: 15/12/2010, $8^{a}$ Turma, Data de Publicação: DEJT 17/12/2010).

${ }^{717} \mathrm{O}$ qual já restou afastado, inclusive, pelo STF: "Agravo regimental no recurso extraordinário com agravo. Trabalhista. Acordo ou convenção coletiva. Inserção de cláusula. Férias. Fracionamento. Legislação infraconstitucional. Ofensa reflexa. Precedentes. 1. O Tribunal Superior do Trabalho concluiu, com base na Consolidação das Leis do Trabalho, pela impossibilidade de inserção de cláusula em acordo ou convenção coletiva que preveja o fracionamento das férias do obreiro fora das exceções legais. 2. Inadmissível, em recurso extraordinário, a análise da legislação infraconstitucional. Incidência da Súmula $\mathrm{n}^{\circ}$ 636/STF. 3. Agravo regimental não provido" (STF - ARE: 681877 MS , Relator: Min. DIAS TOFFOLI, Data de Julgamento: 04/09/2012, Primeira Turma, Data de Publicação: ACÓRDÃO ELETRÔNICO DJe-185 DIVULG 19-09-2012 PUBLIC 20-09-2012).

${ }^{718}$ No entendimento de Amauri Mascaro Nascimento, as matérias de férias e DSR não poderiam ser negociadas in peius com relação às previsões das Convenções $n^{\circ} 14,106$ e 132 da OIT. Porém, em tudo que não seria vedado por referidas convenções, poderia haver negociação (NASCIMENTO, Amauri Mascaro. Limites da negociação coletiva na perspectiva de projeto de flexibilização da CLT.... Op. Cit.,, pp. 1428). 
compõem e não compõem o salário ${ }^{719} 720$ ), alteração da data de pagamento ${ }^{721}$, supressão de parcelas de natureza salarial $^{722}$, determinação do que se considera habitualidade para fins de incorporação de parcelas ao salário ${ }^{723}$, previsão de descontos salariaiis ${ }^{724}$, pagamento em moeda nacional ${ }^{725}$, entre outros ${ }^{726}$, seriam todos afetos à negociação coletiva.

Há importante ressalva, porém, envolvendo políticas salariais impostas pelo governo em épocas de crise econômica - conforme disposto pelo art. 623 da CLT, in verbis:

Art. 623, CLT. Será nula de pleno direito disposição de Convenção ou Acôrdo que, direta ou indiretamente, contrarie proibição ou norma disciplinadora da política econômicofinanceira do Govêrno ou concernente à política salarial vigente, não produzindo quaisquer efeitos perante autoridades e repartições públicas, inclusive para fins de revisão de preços e tarifas de mercadorias e serviços.

\footnotetext{
719 Como, aliás, já vem ocorrendo em matéria de vale-transporte pago em dinheiro: embora exista grande divergência doutrinária a respeito de tal possibilidade, diante do conflito entre as previsões da Lei $n^{\circ}$ 7.418/85 e do Decreto $n^{\circ} 95.247 / 87$, o TST tem permitido à negociação coletiva afastar a natureza salarial de referido pagamento (nesse sentido: AGRAVO DE INSTRUMENTO EM RECURSO DE REVISTA. (...) 2. VALE-TRANSPORTE. INTEGRAÇÃO. PAGAMENTO EM DinheIro. Evidenciado que a concessão do vale-transporte se dava em dinheiro e que o instrumento normativo aplicável à reclamante não permite o pagamento em espécie e nada estabelece quanto à sua natureza jurídica, o fato de o Regional declarar a natureza salarial da parcela e determinar a sua integração nas demais verbas salariais não implica ofensa direta e literal ao art. $7^{\circ}, \mathrm{XXVI}$, da CF. Dissenso de teses não configurado. Agravo de instrumento conhecido e não provido"(TST - AIRR: 1453-27.2010.5.01.0034, Relator: Dora Maria da Costa, Data de Julgamento: 20/11/2013, $8^{\text {a }}$ Turma, Data de Publicação: DEJT 22/11/2013)). Da mesma forma, tem-se mostrado bastante comum em negociações coletivas a determinação de quais parcelas serão ou não atingidas pelos reajustes salariais ocorridos na data-base, afastando-se, por exemplo, os bônus e gratificações pagos aos altos empregados.

${ }^{720}$ Em sentido contrário, o entendimento de Amauri Mascaro Nascimento, para quem "inviável (...) é o uso da convenção e do acordo coletivo para modificar a natureza jurídica de um pagamento, uma vez que a autonomia privada coletiva não tem esse poder, retirado, do seu âmbito, determinar se um determinado tipo de pagamento tem natureza salarial ou não salarial". Segundo o autor, somente a lei pode determinar a natureza de um pagamento, razão pela qual "seria inviável, por acordo coletivo, pactuar que a gratificação mensal não é salário, embora possa a mesma via reduzir essa gratificação ou, até mesmo, suprimi-la" (NASCIMENTO, Amauri Mascaro. Limites da negociação coletiva na perspectiva de projeto de flexibilização da CLT... Op. Cit., pp. 1428).

${ }^{721}$ A qual, aliás, é admitida ainda que feita de forma unilateral pelo empregador, nos termos da OJ-SDI1-159 do TST.

${ }_{722}$ Por exemplo, planos de metas ou bônus não mais interessantes à empresa.

${ }^{723}$ Como, por exemplo, o ocorrido com o plano de PLR da Volkswagen, já analisado.

${ }^{724}$ Conforme autorizado pelo próprio art. 462 da CLT, bem como pela Súmula 342 e pela OJ-SDI1-251, ambas do TST.

${ }^{725}$ Assim, por que não determinar, por exemplo, que um estrangeiro contratado para trabalhar no Brasil venha a ser remunerado, pelo menos em parte, na moeda do país de origem (e.g., se pretende enviar dinheiro para seus familiares que lá permaneceram)?

${ }^{726}$ Em sentido análogo ao quanto acima defendido, Amauri Mascaro Nascimento afirma que seria possível a convenção ou acordo coletivo de trabalho determinar o pagamento do $13^{\circ}$ salário em duodécimos mensais, uma vez que, se a Constituição "autoriza até mesmo a redução, certamente não impede o parcelamento de uma verba de natureza salarial” (NASCIMENTO, Amauri Mascaro. Limites da negociação coletiva na perspectiva de projeto de flexibilização da CLT... Op. Cit., pp. 1428).
} 
Verifica-se, com efeito, que referido dispositivo legal cria norma de absoluta imperatividade no caso de fixação de políticas salariais. Assim, por exemplo, imagine-se que o Brasil enfrente crise econômica e seja proferida determinação governamental para que não haja aumentos de salários durante determinado período visando à recuperação da economia. Se celebrado acordo ou convenção coletiva prevendo aumento salarial, este deverá ser considerado nulo, tendo em vista a prevalência do interesse público sobre o particular nessas circunstancias. ${ }^{727}$

\section{Normas envolvendo cessação do contrato de trabalho}

É certo que as verbas devidas no caso de cessação do contrato de trabalho não poderiam ser objeto de contratação coletiva, tendo em vista seu manifesto caráter de ordem pública. Porém, de outra parte, entendem-se negociáveis as formalidades para rescisão contratual, bem como as espécies de justa causa previstas em lei.

Inicialmente, quanto às formalidades da rescisão, sabe-se que ainda há grandes percalços enfrentados pelas empresas quando da necessidade de homologação do Termo de Rescisão do Contrato de Trabalho, envolvendo, sobretudo, a demora no atendimento pelo sindicato, a recusa na homologação em virtude da ausência de prova de recolhimento das contribuições assistenciais, o excesso de ressalvas apostas, etc. Por meio de acordos de empresa, assim, poder-se-ia prever procedimento específico para a rescisão, realizado no interior da empresa, mas com assistência do Comitê Sindical - tornando mais célere e, ainda assim, eficaz o ato de homologação.

Ademais, entende-se perfeitamente possível a criação de hipóteses de justa causa pela negociação coletiva, diante das peculiaridades da prestação de serviços. Assim, por exemplo, a antiga justa causa prevista pelo art. 508 da CLT $^{728}$, revogada pela Lei $\mathrm{n}^{\circ} 12.347 / 10$, poderia ser reavivada por acordo específico envolvendo determinada instituição financeira; ou mesmo poderia ser prevista, pela via coletiva, justa causa para

\footnotetext{
${ }^{727}$ Conforme dispõe, aliás, o art. $8^{\circ}$, in fine, da CLT: “As autoridades administrativas e a Justiça do Trabalho, na falta de disposições legais ou contratuais, decidirão, conforme o caso, pela jurisprudência, por analogia, por eqüidade e outros princípios e normas gerais de direito, principalmente do direito do trabalho, e, ainda, de acordo com os usos e costumes, o direito comparado, mas sempre de maneira que nenhum interesse de classe ou particular prevaleça sobre o interesse público" (grifou-se).

${ }_{728}$ Art. 508, CLT: Considera-se justa causa, para efeito de rescisão de contrato de trabalho do empregado bancário, a falta contumaz de pagamento de dívidas legalmente exigíveis.
} 
instrutores de programas de emagrecimento que excedam o peso ideal ${ }^{729}$; entre outras hipóteses a serem verificadas em casos concretos.

Finalmente, é preciso repensar a regulamentação da dispensa coletiva pela via negocial. A pura e simples determinação, por parte do $\operatorname{TST}^{730}$, de que quaisquer rescisões contratuais coletivas ou em massa necessitam do aval do sindicato - sem respaldo legal e diante da denúncia da Convenção 158 da OIT - é inadequada. Melhor seria, mais uma vez, que se atribuísse aos próprios interlocutores sociais a competência para disciplinar o procedimento de tal forma de rescisão contratual. ${ }^{731}$

\section{Tutelas de novas formas de trabalho}

Talvez a mais importante atuação do sindicato, porém, seja na regulamentação de formas alternativas de prestação de serviços, como o trabalho autônomo dependente e a pejotização. ${ }^{732}$

De fato, referidas formas de contratação são realidade no mercado de trabalho hodierno e, por tal razão, não podem simplesmente restar ignoradas pelo sistema legal. O mero argumento de que, por não se amoldarem ao contrato de trabalho previsto pela CLT, não merecem tutela específica, ou devem ser reconduzidas ao trabalho subordinado (presumindo-se a fraude), é falho e não atende aos anseios de empregados e empregadores que optam por essas formas de trabalho.

Assim é que, no modelo negociado, deveria ser atribuído aos próprios sindicatos o poder de reconhecer tais métodos alternativos de prestação de serviços, bem como consagrar mínimos de direitos a serem assegurados aos trabalhadores. Ademais, os acordos específicos de empresa seriam responsáveis por determinar em que situações e para que categorias tais formas de contratação se admitiriam, bem como quais os procedimentos a serem observados durante a prestação de serviços para que não se configure autêntico trabalho subordinado.

\footnotetext{
729 Em sentido contrário, o entendimento do TST, que afastou a justa causa aplicada a orientadora dos Vigilantes do Peso por ter engordado (Notícia disponível online em http://tst.jusbrasil.com.br/noticias/100364604/turma-afasta-justa-causa-de-orientadora-do-vigilantes-do-pesodemitida-por-engordar).

${ }^{730}$ Cf. supra, nota $n^{\circ} 678$.

731 A respeito do tema, cf. MANNRICH, Nelson. Dispensa Coletiva: Da liberdade contratual à responsabilidade social. São Paulo: LTr, 2000.

732 Para análise mais detalhada dessas formas de trabalho, retome-se a dissertação de mestrado por nós apresentada, em 2011, perante a Faculdade de Direito da Universidade de São Paulo, disponível online em http://www.teses.usp.br/teses/disponiveis/2/2138/tde-18052012-135740/pt-br.php.
} 
É preciso, nesse sentido, romper com a hegemonia do trabalho formal e reconhecer que não apenas o empregado subordinado é merecedor das tutelas legais.

Também a terceirização poderia ser objeto de negociação específica na empresa ou na categoria.

Com efeito, já se ressaltaram as dificuldades encontradas na regulamentação da terceirização pela via legal ${ }^{733}$, diante das divergências envolvendo o conceito de atividade-fim e de abrangência da responsabilidade da empresa tomadora de serviços. Por que não, assim, atribuir competência à negociação coletiva para disciplinar tal método de prestação de serviços, em face da necessidade concreta de cada empresa? No mínimo, evitar-se-ia, dessa forma, a proliferação das ações judiciais - especialmente propostas pelo Ministério Público do Trabalho - questionando terceirizações em atividades que se encontram no "limbo" entre a finalidade principal da empresa e suas atividades acessórias.

E, no que tange especificamente à terceirização e às demais formas alternativas de prestação de serviços, entende-se que poderiam ser regulamentadas não apenas por acordos específicos de empresa, mas também por convenções coletivas de categorias - na medida em que o sindicato, conhecedor da realidade da categoria por ele representada, poderia determinar quais as atividades que admitem ou não referidas formas de contratação.

\subsubsection{Vedações à negociação}

Como forma de manter a coerência com o sistema tutelar que sempre norteou o Direito do Trabalho, entretanto, é necessário reconhecer que determinadas matérias encontram-se totalmente vedadas à negociação coletiva.

Inicialmente, restam excluídos os direitos constitucionais do trabalhador, i.e., aqueles previstos pelo art. $7^{\circ}$ da $\mathrm{CF} / 88$ e 10 do ADCT, salvo quando o próprio sistema constitucional admitir sua flexibilização pela via negocial. Nesse aspecto, aliás, é mister salientar que muitos ordenamentos jurídicos, como o espanhol e o francês ${ }^{734}$, reconhecem a imperatividade absoluta dos direitos constitucionais, afastando a possibilidade de negociação quer in melius, quer in peius. No direito brasileiro, diante da

\footnotetext{
${ }^{733}$ Cf. supra, capítulo 5, item 5.2

${ }^{734}$ Cf. supra, capítulo 4, itens 4.3.2 e 4.3.4.
} 
fórmula consagrada pelo próprio caput do art. $7^{\circ}$ ("São direitos dos trabalhadores urbanos e rurais, além de outros que visem à melhoria de sua condição social (...)"), entende-se que complementação dos direitos pela via negocial é plenamente admitida, em face de normas relativamente imperativas.

Também as normas previstas em lei complementar são afastadas do âmbito da negociação, como, por exemplo, a indenização de 40\% do FGTS no caso de dispensa sem justa causa ou rescisão indireta do contrato de trabalho (prevista pela LC $\mathrm{n}^{\circ}$ 101/00) e a recém consagrada estabilidade ao guardião da criança, no caso de falecimento da genitora ( $\left.\operatorname{LC~} n^{\circ} 146 / 14\right)$.

\section{Ainda, as regras envolvendo garantias de emprego e estabilidades.}

Nunca se contestou a possibilidade de criação de estabilidades e garantias de emprego pelas próprias partes sociais, por meio da negociação coletiva; como exemplos, têm-se a garantia de emprego no caso de doença ou acidente comum, a decorrente da préaposentadoria, a garantia de emprego ao homem no caso de nascimento de filho, entre outras. $^{735}$ Questionamento surge, entretanto, com relação à negociação in peius das estabilidades previstas por lei ou pela própria Constituição - rechaçando-se, de plano, tal possibilidade. $^{736}$

Também são inegociáveis as normas de proteção ao trabalho da mulher e do menor, tendo em vista seu nítido caráter tutelar. Tanto é verdade que, para alguns autores ${ }^{737}$, aludidas normas - juntamente com aquelas relacionadas à saúde e segurança no trabalho - inserem-se em ramo específico do Direito do Trabalho, o "Direito Tutelar do Trabalho", que repousaria ao lado do Direito Individual e do Direito Coletivo.

Nesse sentido, aliás, o posicionamento de Amauri Mascaro Nascimento, para quem a proteção deve ser unificada, não sendo possível que determinada empresa (ou categoria) estipule regras específicas aplicáveis apenas aos menores e mulheres que nela

\footnotetext{
735 Não por outra razão, aliás, a Súmula 98 do TST regulamenta a instituição de estabilidade decenal por meio do próprio contrato de trabalho ou regulamento interno de empresa; nesse sentido, a OJ-SDI1-41, do mesmo tribunal, acerca da garantia de emprego decorrente de acidente ou doença profissional prevista por instrumento normativo.

${ }^{736}$ Em sentido contrário, Amauri Mascaro Nascimento defende que as hipóteses de garantia de emprego que não venham previstas constitucionalmente poderiam ser livremente negociadas - exceto aquela envolvendo acidente do trabalho, por se inserir em matéria de saúde e segurança no trabalho e direitos previdenciários (NASCIMENTO, Amauri Mascaro. Limites da negociação coletiva na perspectiva de projeto de flexibilização da CLT... Op. Cit., p. 1429).

${ }^{737}$ Nesse sentido, cf., por todos, MARTins, Sergio Pinto. Direito do Trabalho... Op. Cit, p. 529.
} 
trabalhem. Ademais, não se pode confundir o caráter eminentemente tutelar desses normas com o viés protecionista que norteia o trabalho do adulto, já que este admite adaptações. ${ }^{738}$

Embora não se trate, propriamente, de matéria afeta ao Direito do Trabalho, por certo poderão surgir questionamentos a respeito da possibilidade de a negociação coletiva imiscuir-se em matéria previdenciária - ainda que para prever novos direitos ao trabalhador/segurado.

Ora, sabe-se que, desde seus primórdios, a legislação previdenciária é matéria afeta ao direito público - logo, a negociação coletiva, por óbvio, não pode nela atuar (tanto que a doutrina mais especializada é uníssona ao reconhecer que acordos e convenções coletivas de trabalho, assim como o costume, não podem ser considerados fontes de direito previdenciário ${ }^{739}$ ). Não é possível à contratação coletiva, nesse sentido, prever novos benefícios a serem garantidos pelo Instituto Nacional do Seguro Social ou mesmo reduzir aqueles já concedidos - eis que referida autarquia nunca será parte em tal negociação.

Por outro lado são passíveis de negociação coletiva direitos envolvendo Previdência Complementar - como ocorre, por exemplo, com cláusulas normativas que preveem complementação de aposentadoria ou de auxílio-doença, ampliação da licençamaternidade, etc. Porém, nesse ponto, não há que se falar em verdadeira prevalência do negociado sobre o legislado, já que, respeitadas as regras legais, a criação de sistemas complementares é livre aos particulares. ${ }^{740}$

No que tange a direitos coletivos, entende-se que as matérias atinentes à negociação já vêm expressamente discriminadas por lei - como, e.g., a fixação de contribuição confederativa diretamente pelos interlocutores sociais (cf. art. $8^{\circ}$, IV, da $\mathrm{CF} / 88$ ). Outras matérias, como organização sindical, representação dos trabalhadores na empresa, estrutura da negociação coletiva, são exclusivas da regulamentação estatal e, portanto, alheias ao âmbito do negociado. ${ }^{741}$

\footnotetext{
738 NAscimento, Amauri Mascaro. Limites da negociação coletiva na perspectiva de projeto de flexibilização da CLT... Op. Cit. p. 1429.

${ }^{739}$ A respeito, cf. MARTInS, Sergio Pinto. Direito da Seguridade Social. 34a Ed.. Atlas, São Paulo, 2014, pp. 39-41; Horvath Junior, Miguel. Direito Previdenciário. 9a Ed.. São Paulo: Quartier Latin, 2012, pp. 60 e SS.

${ }^{740}$ Mesmo porque os sistemas complementares envolvem entidades que não se enquadradam na relação de emprego.

${ }^{741}$ Nesse sentido, o entendimento de NASCimento, Amauri Mascaro. Limites da negociação coletiva na perspectiva de projeto de flexibilização da CLT... Op. Cit., p. 1421. Especificamente com relação à greve, o autor apresenta interessante posicionamento: entende ser impossível, pela via negocial, a alteração do rol das
} 
Importante questionamento surge, nesse aspecto, com relação aos dissídios coletivos de natureza econômica: poderiam as sentenças normativas fixar normas menos vantajosas ao trabalhador, após o regular procedimento do dissídio?

Considerando que, depois da Emenda Constitucional n ${ }^{\circ} 45$, de 2004, o Poder Normativo da Justiça do Trabalho passa a ser, em tese, fruto da própria vontade das partes (eis que necessário o requisito do "comum acordo" para sua atuação), entende-se que a sentença normativa poderia, sim, alterar in peius condições de trabalho previstas por lei ou negociação coletiva anterior - e ainda com mais autoridade do que as próprias convenções e acordos coletivos de trabalho, já que feita perante o Judiciário. Ora, se, no âmbito individual, admitem-se transações efetuadas diante do magistrado trabalhista (acordos efetuados em audiência), por que não estender tal possibilidade à esfera coletiva, não mediante acordo, mas adaptação de normas pelo próprio órgão julgador, conforme as necessidades do caso concreto?

Sabe-se da dificuldade de reconhecer-se legalmente tal possibilidade, diante da previsão constitucional de que, no dissídio coletivo de natureza econômica, poderá "a Justiça do Trabalho decidir o conflito, respeitadas as disposições mínimas legais de proteção ao trabalho, bem como as convencionadas anteriormente" (art. 114, §2, $\mathrm{CF} / 88$ - grifou-se). Seria necessário, com efeito, conferir interpretação precisa ao dispositivo, para determinar quais as "disposições mínimas" por ele referidas. Ademais, a atuação da Justiça do Trabalho não seria totalmente desprovida de limites: em primeiro lugar, as normas que aqui se defendem como de absoluta imperatividade não poderiam ser alteradas; em segundo lugar, qualquer modificação in peius deveria ser devidamente fundamentada pelo Tribunal, pautado nas circunstâncias do caso concreto.

Ainda, o negociado não pode avançar na esfera do Direito Público do Trabalho, ou seja, na atuação do Ministério do Trabalho e Emprego. Assim é que, por exemplo, não pode um acordo ou uma convenção coletiva de trabalho regulamentar os

atividades essenciais constante do art. 10 da Lei $\mathrm{n}^{\mathrm{o}} 7.783 / 89$, bem como da maioria das formalidades envolvendo deflagração da greve (como autorização prévia pela assembleia) e direitos e proibições ao grevista (vedação ao piquete não pacífico e ao lock-out, direito de livre divulgação do movimento, etc.), por se tratar de normas não afetas ao interesse do trabalhador (ou seja, simples "condições de trabalho"), mas sim ao interesse público. Porém, defende o mesmo autor que normas meramente procedimentais poderiam ser reguladas por negociação coletiva: assim, por exemplo, poder-se-ia estipular maior período de aviso prévio de greve em determinadas atividades (mesmo em contrariedade aos interesses dos grevistas), determinar-se a forma de preservação das atividades essenciais e, obviamente, salários (conforme já previsto pelo próprio art. $7^{\circ}$, da Lei) etc. (NASCIMENTO, Amauri Mascaro. Limites da negociação coletiva na perspectiva de projeto de flexibilização da CLT... Op. Cit., p. 1422). 
procedimentos de emissão da Carteira de Trabalho e Previdência Social (CTPS) ou de fiscalização. ${ }^{742}$

Da mesma forma, não está a negociação coletiva legitimada a tratar de Direito Penal do Trabalho, por se estar diante de normas de Direito Público. Aqui se incluem, além das condutas tipificadas no Código Penal (Crimes contra a Organização do Trabalho), eventuais delitos previstos na própria legislação trabalhista (como, e.g., a penalização de atos abusivos na greve, pela Lei 7.783/89, a retenção dolosa de salários, constante do Decreto-Lei no $368 / 68$, o crime de exigência de teste, exame ou procedimento relativo à esterilização ou a estado de gravidez e adoção de medidas de controle de natalidade, da Lei $\mathrm{n}^{\circ}$ 9.029/95, etc.).

O mesmo pode ser dito com relação às Convenções da OIT Organização Internacional do Trabalho. Não se pretende, aqui, adentrar na discussão a respeito da natureza jurídica de referidas Convenções, quando ratificadas pelo ordenamento brasileiro. Entretanto, considerando o compromisso assumido pelo Brasil enquanto membro de referida Organização, por óbvio, não se pode admitir que a negociação coletiva altere, in peius, previsões constantes de tais instrumentos internacionais. A entender-se de outro modo, estar-se-iam violando princípios de direito internacional decorrentes da adesão de determinado país a uma organização internacional e consequente ratificação de seus atos.

Finalmente, interessantes discussões norteiam as normas de medicina e segurança no trabalho, sendo lugar-comum em doutrina a afirmação de que estas não podem, em hipótese alguma, ser objeto de negociação coletiva. ${ }^{743}$

É preciso, porém, ter cuidado com o conceito de "normas de medicina e segurança" no trabalho, na medida em que sua ampliação injustificada implicaria interpretar como tais as normas sobre descanso semanal remunerado, férias, intervalos, etc. Assim, partindo dos ensinamentos de Gustavo Filipe Barbosa Garcia $^{74}$, entende-se que são

\footnotetext{
${ }^{742}$ Exceção a referida proibição, como visto, é a possibilidade de previsão de procedimentos de homologação de termos de rescisão do contrato de trabalho por meio da negociação coletiva. Porém, ressalte-se: o acordo coletivo poderia, somente, prever procedimento diferenciado a ser feito na empresa, mas jamais se imiscuir nas normas procedimentais ditadas pelo MTE para as homologações ocorridas perante esse órgão.

${ }_{743}$ Cf., por exemplo, NASCIMENTO, Amauri Mascaro. Limites da negociação coletiva na perspectiva de projeto de flexibilização da CLT... Op. Cit., p. 1425. No mesmo sentido, recorde-se que o Projeto de Lei ${ }^{\circ}$ 5.483/01 expressamente retirava tais normas do âmbito da negociação coletiva (cf. supra, capítulo 5, item $5.3)$

${ }_{744}$ GARCIA, Gustavo Filipe Barbosa. Meio ambiente do trabalho: direito, segurança e medicina do trabalho. $3^{a}$ Ed.. São Paulo: Gen/Método, 2011, pp. 26 e ss.
} 
normas de medicina e segurança aquelas previstas pelo Título II, Capítulo V, da CLT (arts. 154 e ss), complementadas pelas Normas Regulamentadoras editadas pelo Ministério do Trabalho.

Delimitado o conceito, entende-se que referidas normas também são infensas à negociação coletiva. Assim, por exemplo, não poderia um acordo ou uma convenção coletiva isentar a empresa de constituir órgãos de saúde e segurança no trabalho (arts. 162 a 165, CLT) ou de fornecer equipamentos de proteção individual (arts. 166 e 167, CLT), bem como de alterar os agentes considerados nocivos ou perigosos pelas Normas Regulamentadoras $n^{\circ} 15$ e 16, do MTE, respectivamente.

Com base em referido entendimento, aliás, é que ocorreu o já mencionado cancelamento do item II da Súmula 364 do TST - o qual previa a possibilidade de fixar-se, mediante convenção coletiva, adicional de periculosidade inferior a $30 \%$ para hipóteses de contato meramente intermitente com o agente de risco.

Com efeito, sempre houve inúmeras críticas a referida previsão sumular do TST, tendo em vista o entendimento de que os adicionais, tanto de insalubridade quanto de periculosidade, seriam afetos à matéria de saúde do trabalhador - e, portanto, tratar-seia de direitos indisponíveis. A justificar entendimento contrário, como o previsto na Súmula, restava o argumento de que não se poderia confundir adicionais (de insalubridade e periculosidade) com agentes insalubres e perigosos: estes, verdadeiramente integrantes da matéria de saúde e segurança do trabalhador, aqueles inseridos na disciplina do salário e da remuneração. ${ }^{745}$ Assim, os adicionais enquadrar-se-iam na previsão do art. $7^{\circ}$, VI, da $\mathrm{CF} / 88$ - permitindo-se, portanto, sua redução pela via coletiva.

Não foi, porém, o entendimento que prevaleceu, já que, em 2011, o Tribunal Superior do Trabalho cancelou o referido item II da Súmula, negando à negociação coletiva a fixação de percentual inferior do adicional de periculosidade.

Entende-se, contudo, que referido posicionamento mostra-se equivocado, partilhando-se do posicionamento de que o adicional de periculosidade insere-se na matéria relativa aos salários - e, portanto, poderia ser adaptado pela negociação coletiva no caso de contato intermitente com o risco.

\footnotetext{
${ }^{745}$ A respeito, cf. NASCIMENTO, Amauri Mascaro. Limites da negociação coletiva na perspectiva de projeto de flexibilização da CLT... Op. Cit., p. 1426.
} 
Em síntese, como se percebe, ainda há grande espaço normativo que poderia ser destinado à negociação coletiva, sem qualquer comprometimento dos princípios basilares do Direito do Trabalho. É certo que muito se evoluiu desde a Constituição Federal de 1988; porém, a expectativa de se criar um Direito do Trabalho ainda mais adequado à complexa realidade social hodierna motiva o estudioso a apresentar propostas de fortalecimento das competências sindicais. Foi o que se buscou com o presente capítulo. 


\section{Conclusão}

A atribuição de maior importância ao modelo negociado, no Brasil, é imperiosa. Em primeiro lugar, porque a flexibilização da legislação trabalhista é tendência natural em mercados transnacionais e extremamente competitivos, como o contemporâneo; em segundo, porque a própria Constituição Federal de 1988 confere à negociação coletiva a capacidade de adaptar a lei ao caso concreto, reconhecendo a natureza de verdadeira fonte de direito de seus frutos.

Porém, na consolidação desse modelo, alguns parâmetros precisam ser observados.

A começar, deve-se ter em mente a função essencial do Direito do Trabalho, qual seja, a proteção da relação de trabalho. Não a proteção pura e simples do trabalhador, na medida em que ambas as partes sociais merecem, em certa medida, a tutela estatal; nem tampouco a proteção exclusiva da relação de emprego, já que toda espécie de prestação de serviços deve ser disciplinada, independentemente de se amoldar ou não aos restritos critérios da CLT.

Busca-se, com efeito, não apenas tutelar o contrato de trabalho já celebrado, mas também coibir as elevadas taxas de desemprego e informalidade do mercado laboral, de forma a garantir que o Direito do Trabalho atue como verdadeiro regulador da "questão social".

Em segundo lugar, não se pode apregoar o absoluto afastamento do Estado na regulamentação das condições de trabalho, sendo necessário combinar sua atuação com a dos interlocutores sociais. Como se viu, nenhum sistema é capaz de se sustentar exclusivamente em um único modelo, negociado ou legislado. Por isso, cabe à lei determinar o espaço reservado à autonomia privada coletiva.

Em terceiro, embora se faça análise de diversos ordenamentos jurídicos estrangeiros no presente trabalho, cumpre reconhecer que as experiências observadas não podem ser, ipsis literis, transplantadas à realidade brasileira. Consoante referido, o estudo do direito comparado é essencial quando se pretende a revisitação de modelos jurídicos consolidados; entretanto, a experiência estrangeira deve ser adaptada à realidade pátria - 
que, sobretudo em matéria sindical, difere da realidade de outros países, em virtude da não ratificação, pelo Brasil, da Convenção no 87 da Organização Internacional do Trabalho.

Por outro lado, se é certo que temas como unicidade sindical, contribuição compulsória e poder normativo da Justiça do Trabalho precisam ser enfrentados para a adaptação de modelos estrangeiros à realidade brasileira, não se pode rechaçar qualquer tentativa de alteração do sistema legislado sob o argumento de que esta deve ser precedida de reforma sindical. É necessário trabalhar com o modelo hoje vigente, buscando nele as soluções para o fortalecimento da negociação coletiva - sob pena de postergar-se qualquer alteração a um futuro nem um pouco próximo.

Ademais, diversos critérios objetivos devem ser observados na modulação, in concreto, da lei estatal pela contratação coletiva.

O primeiro, certamente, envolve a aferição da representatividade do sindicato. Partindo do pressuposto de que a negociação de regras estatais deve ser obrigatoriamente coletiva (já que, em âmbito individual, prevalece a indisponibilidade de direitos pelo trabalhador), cumpre especificar qual o ente legitimado para promover referida negociação.

Critérios objetivos também devem ser adotados para tal fim - em especial, a habilitação junto ao Ministério do Trabalho e Emprego, a qual apenas será concedida a sindicatos que, cumulativamente: a) comprovarem a instalação de Comitê Sindical de Empresa (CSE) em uma ou mais empresas de sua base de representação, composto por no mínimo dois e no máximo 32 membros; b) tiverem o CSE reconhecido, pela empresa, como órgão de representação do sindicato profissional no local de trabalho (mediante acordo coletivo celebrado para este fim); e c) apresentarem índice mínimo de sindicalização de $50 \%$ mais 1 do total dos trabalhadores da empresa que pretende negociar condições de trabalho.

Atendendo a referidos critérios, evitar-se-á que sindicatos fracos e facilmente corruptíveis alterem in peius a legislação, sem gozarem de efetiva aceitação pelos trabalhadores que representam.

Além disso, a especificação da abrangência da contratação coletiva é essencial para garantir que esta seja, de fato, determinada por necessidades concretas dos empregados e empregadores. Nesse contexto, quanto menor a abrangência do acordo, 
maior a chance de se atingir tal escopo; por essa razão, defende-se a negociação in peius de condições de trabalho apenas no âmbito empresarial.

Ainda, repetindo a experiência já consagrada pelo artigo $614, \S 3^{\circ}$, da CLT, não se deve admitir que a contratação in peius tenha eficácia indeterminada no tempo. Se qualquer negociação (seja para melhor ou para pior), hoje, já tem seu prazo limitado a dois anos, com ainda maior razão deve ser restringida no tempo a alteração da lei com prejuízo ao trabalhador. Além do mais, o motivo da alteração deve constar expressamente do instrumento negocial, de forma a justificar os limites da vigência deste.

Talvez a pedra de toque para adoção de referido modelo, contudo, seja a delimitação das matérias passíveis de serem negociadas diretamente pelos atores sociais.

Nesse contexto, as normas absolutamente imperativas (i.e., que não permitem qualquer alteração, quer in melius, quer in peius) devem ser exceção, pois, em um Estado Democrático de Direito, não há justificativa para que a lei subtraia de todo determinada matéria à negociação coletiva. Por seu turno, as normas relativamente imperativas (i.e., que somente admitem modificação in peius) devem ser a regra geral, por força da própria gênese do Direito do Trabalho.

Porém, devem ser ampliadas as hipóteses de normas supletivas ou dispositivas, i.e., que permitem seu afastamento em qualquer sentido, seja in melius, seja in peius - desde que operado pelo real detentor do interesse coletivo, i.e., o ente sindical.

Embora, como visto, a Constituição e a legislação já prevejam normas dispositivas, estas ainda são exceção. Contudo, percebe-se que as previsões constitucionais admitem a flexibilização de temas basilares do Direito do Trabalho: duração e salário. Não é crível, assim, admitir que o constituinte - ao conceder tão elevada competência à negociação coletiva - tenha pretendido a supletividade da lei como exceção, apenas destinada a matérias acessórias ao contrato de trabalho (como parece ser o entendimento do Tribunal Superior do Trabalho, o qual, como visto, cada vez mais vem restringindo a atuação da negociação coletiva).

Assim, além das matérias já destinadas à negociação, outras devem ser a ela permitidas, sobretudo envolvendo duração do trabalho, férias e descanso semanal remunerado, salário e remuneração, cessação do contrato e tutelas de novas formas de contratação. 
Especialmente com relação às últimas, sobreleva a importância da autonomia privada coletiva, em face da ausência de regulamentação específica pelo Estado. Quem, senão as próprias partes, possui maior legitimidade para especificar as condições da terceirização, os direitos do trabalhador autônomo dependente, as hipóteses em que se admite a pejotização?

Ao se ampliar a competência da negociação, assim, além de adaptaremse normas às relações de trabalho em concreto, permitir-se-ia a disciplina particularizada de matérias cuja regulamentação no âmbito nacional ainda esbarra em interesses políticos e econômicos contrapostos.

Porém, a supremacia do modelo negociado não será possível sem a superação de grande entrave a sua implementação: a presunção de fraude generalizada, ainda arraigada entre os órgãos de tutela das relações de trabalho (i.e., Justiça do Trabalho, Ministério Público do Trabalho, Ministério do Trabalho e Emprego e - por que não? - dos próprios sindicatos).

É preciso, com efeito, abandonar-se a concepção de que qualquer tentativa de adaptação da lei, por parte da empresa, é fraudulenta e tem por intuito tãosomente a redução de encargos sociais, solapando direitos consolidados. Por óbvio, há empresas antiéticas e desonestas, que visam apenas ao lucro, independentemente dos meios adotado para tanto; porém, sua existência não pode implicar generalização, desconsiderando-se empregadores realmente preocupados com o bem-estar de seus empregados e com a boa relação entre capital e trabalho para a consecução das finalidades empresariais.

Se a empresa chama o sindicato a negociar condições de trabalho, isso, de per si, já demonstra seu comprometimento com a observância da legislação trabalhista uma vez que, se desonesta fosse, simplesmente adaptaria a lei a seu caso concreto e arcaria sozinha com os riscos de tal conduta. Por seu turno, se o sindicato, partindo da presunção de fraude, recusa-se à negociação, está perdendo grande oportunidade de valorizar sua atuação no mercado de trabalho brasileiro e de demonstrar sua verdadeira preocupação com os anseios da classe trabalhadora.

Os órgãos responsáveis pela inspeção do trabalho, por sua vez, ademais de se aterem à estrita aplicação de dispositivos legais - muitos dos quais obsoletos -, deveriam priorizar a intenção das partes nas relações laborais, especialmente naquelas que 
envolvem trabalhadores esclarecidos, com amplo poder de negociação e plena participação na vida empresarial. Simplesmente desconsiderar uma contratação mediante pessoa jurídica, por parte de trabalhador que exerce atividade extremamente intelectualizada, com um nome no mercado e, inclusive, prestando seus serviços a outros clientes, é contrariar, no mínimo, norma de direito positivo que prioriza a boa-fé das partes na celebração de contratos (art. 113 do Código Civil pátrio).

Finalmente, conforme se defendeu no decorrer do presente estudo, entende-se que a superação do modelo estritamente legislado tende a promover a própria reforma sindical, na medida em que sindicatos preocupados em adaptar a legislação aos casos concretos tendem a aproximar-se das empresas e dos trabalhadores - principalmente na tentativa de superar a consciência quase que geral no sentido de que apenas faz lei o que é positivado pelo Estado. 


\section{REFERÊNCIAS}

ABrantes, João José. Direito do Trabalho - ensaios. Lisboa: Cosmos, 1995.

. O Código do Trabalho e a Constituição. In Questões Laborais: Código do

Trabalho - questões de (in)constitucionalidade. Ano X, Coimbra Editora, Coimbra, 2003.

Aguiar, Antonio Carlos. Negociação coletiva de trabalho. São Paulo: Saraiva, 2001.

Alfonso Mellado, Carlos L.. La reforma de la negociación colectiva en la ley 3/2012: la vigencia del convenio y el problema de la ultraactividad. Palestra proferida na XXV Jornada de Estudio sobre Negociación Colectiva - La reforma laboral de 2012, Madrid, 4 de octubre de 2012, disponível online em http://www.observatorionegociacioncolectiva.org/comunes/recursos/99998/doc126879 La reforma_de_la_negociacion_colectiva_en_la_Ley_3-

2012 La vigencia_del convenio y el problema de la ultraactividad..pdf, acesso em $17 / 11 / 14$, às $18 \mathrm{~h}$.

Alonso Olea, Manuel. Introdução ao Direito do Trabalho. 4a Ed.. São Paulo: LTr, 1984.

Amado, João Leal. A Reforma do Código do Trabalho. Coimbra Editora: Coimbra, 2004. $\overline{\text { Editora, } 2010 .}$

. Contrato de Trabalho. $2^{\text {a }}$ Ed. Coimbra: Wolters Kluwer Portugal/Coimbra

- Negociado x legislado. O princípio do tratamento mais favorável ao $\overline{\text { trabalhador }}$ e as relações entre a lei e a convenção colectiva em Portugal. In Cadernos de Pós-graduação em Direito: estudos e documentos de trabalho / Comissão de Pósgraduação da Faculdade de Direito da USP, São Paulo, n. 1, 2011.

. Tratamento mais favorável e art. $4 .^{\circ}, n .^{\circ} 1$, do código do trabalho português: o fim de um princípio? In Revista Evocati, n. 19, jul. 2007. Disponível online em http://www.evocati.com.br/evocati/artigos.wsp?tmp_codartigo=132. Acesso em: $31 / 08 / 2014$, às $17 \mathrm{~h}$. 
Antunes, Carlos e PERDIGÃO, Carlos. Relações Laborais e Direito do Trabalho Tendências Futuras. In Minerva - Revista de Estudos Laborais, ano VI, $\mathrm{n}^{\mathrm{o}}$ 10, março de 2007, Lisboa.

ANTUNES, Ricardo. O caracol e sua concha - ensaios sobre a nova morfologia do trabalho. São Paulo: Boitempo Editorial, 2005.

APEL, Karl-Otto. How to ground a universalistic ethics of co-responsibility for the effects of collective actions and activities? In Philosofica, $\mathrm{n}^{\mathrm{o}} 52$ (1993, 2).

BARBAto JR.. Pluralismo Jurídico e Criminalidade Brasileira. In Wolkmer, Antonio Carlos et al. Pluralismo Jurídico: os novos caminhos da contemporaneidade. $2^{\mathrm{a}}$ edição. São Paulo: Saraiva, 2013.

Barros, Alice Monteiro de. Curso de Direito do Trabalho. $9^{\text {a }}$ Ed.. São Paulo: LTr, 2013.

Flexibilização e garantias mínimas. In Revista Trabalho \& Doutrina, n. 20. São Paulo: Saraiva, 1999.

BARros, Cássio Mesquita. Modernização da CLT à luz da realidade brasileira. In Revista da Faculdade de Direito da Universidade de São Paulo - FDUSP, vol. 86, 1991.

Barros Junior, Cássio de Mesquita, O futuro do direito do trabalho, in Zainaghi, Domingos Sávio e Frediani, Yone (coord.). Novos rumos do direito do trabalho na América Latina. São Paulo: LTr, 2003.

Bettencourt, Pedro Ortins de. As novas ameaças ao direito do trabalho. In V Congresso Nacional de Direito do Trabalho - Memórias. Coimbra: Almedina, 2003.

BIAgI, Marco e TIRABOSCHI, Michele. Istituzioni di diritto del lavoro. Milano: Giuffrè, 2012.

BobBIo, Norberto. La consuetudine come fatto normativo. Torino: G. Giappichelli, 2010 .

. Teoria da Norma Jurídica. São Paulo: EDIPRO, 2001.

. Teoria do Ordenamento Jurídico. 6 6 edição. Brasília: UnB, 1995. 
. Teoria Geral do Direito. Martins Fontes: São Paulo, 2007.

BOLDT, Gerhard. Le fonti del diritto del lavoro in Germania In BOLDT, Gerhard; DuRAND, Paul; Horion, Paul; Kayser, Armand; Mengoni, Luigi; MolenaAR, A. N. Le Fonti Del Diritto Del Lavoro. Comunità Europea del Carbone e dell'acciaio - Alta autorità, Luxemburgo, 1962.

BorbA, Joselita Nepomuceno. Subordinação jurídica - Parassubordinação - Contrato de atividade - a busca de uma nova dogmática para a relação de trabalho. In Revista de Direito do Trabalho, ano 30, nº 116, outubro-dezembro de 2004, São Paulo.

BronzINI, Giuseppe. Come evitare la 'segmentazione' del mercato del lavoro: la filosofia della flexicurity e $i$ contratti a termine. In $\mathbf{D} \& \mathbf{L}$ - Rivista critica di diritto del lavoro, $\mathbf{n}^{\circ}$ 4, ottobre-dicembre 2008.

CAmargos, Regina Coeli Moreira. O movimento sindical diante da reforma das suas instituições: visões e contradições. In Revista ABET, vol. IX, n. 2/2010.

Canotilho, Joaquim José Gomes et Moreira, Vital. Constituição da República Portuguesa Anotada. 3. a edição. Coimbra: Coimbra Editora, 1993.

CAnotilho, Joaquim José Gomes. Direito Constitucional. $6^{\text {a }}$ edição. Coimbra: Almedina, 1993.

Carvalho, António Nunes. O pluralismo do Direito do Trabalho. In III Congresso Nacional de Direito do Trabalho. Coimbra: Almedina, 2000.

Carvalho, Lucas Borges de. Caminhos (e descaminhos) do pluralismo jurídico no Brasil. In Wolkmer, Antonio Carlos et al. Pluralismo Jurídico: os novos caminhos da contemporaneidade. $2^{\mathrm{a}}$ edição. São Paulo: Saraiva, 2013.

Castelo, Jorge Pinheiro. Transformações do mercado de trabalho brasileiro - Prestação de serviços intelectuais por pessoas jurídicas - Aspectos legais, econômicos e tributários Desconstruindo e construindo o paradigma de pensamento. In ANAN JR., Pedro e PEIXOTO, Marcelo Magalhães (Coord.). Prestação de Serviços Intelectuais por Pessoas Jurídicas - Aspectos Legais, Econômicos e Tributários. São Paulo: MP Editora, 2008. 
CESARINO JúnIOR, A. F.. Direito social: denominação, conceito e conteúdo. In Revista da Faculdade de Direito da Universidade de São Paulo, v. 35, n. 1 (1939).

Cesarino Junior, A.F.. Direito Social Brasileiro. 6ª Ed.. São Paulo: Saraiva, 1970.

Contreras Peláez, Francisco J.. Derechos sociales: teoría e ideología. Madrid: Tecnos, 1994.

Correa Carrasco, Manuel. Convenios e Acuerdos Coletctivos de Trabajo. Pamplona: Editorial Aranzadi, 1997.

CRUZ Villalón, Jesús. Texto y contexto de la reforma de la negociación colectiva 2011. In CRUZ Villalón, Jesús et al. La Reforma de la negociación colectiva. Valladolid: Lex Nova, 2011.

Delgado, Mauricio Godinho. Curso de Direito do Trabalho. $11^{\text {a }}$ Ed.. São Paulo: LTr, 2012.

DRI, Clarissa Franzoi. Antiformalismo Jurídico: uma Abordagem Institucionalista da Integração Regional. In Cadernos PROLAM/USP, ano 8, vol. 1, 2008.

Domenico, Dalfino. La nuova giustizia del lavoro. Bari: Cacucci, 2011.

DuRAND, Paul. Le fonti del diritto del lavoro in Francia In BoldT, Gerhard; DuRAND, Paul; Horion, Paul; Kayser, Armand; Mengoni, Luigi; MolenaAr, A. N. Le Fonti Del Diritto Del Lavoro. Comunità Europea del Carbone e dell'acciaio - Alta autorità, Luxemburgo, 1962.

Felicio, João Antonio. A flexibilização da CLT a ser votada no Senado beneficia o trabalhador? NÃO - Um projeto que retira direitos. In Folha de São Paulo, edição de 29 de dezembro de 2001.

Fernandes, António Monteiro. Direito do trabalho. 15 a edição. Coimbra: Almedina, 2010.

. Um direito do trabalho sobrevivente. In MoReIRA, António José (coord). Estudos jurídicos em homenagem ao Professor António Motta Veiga. Coimbra: Almedina, 2007. 
Ferraz Junior, Tercio Sampaio. Introdução ao Estudo do Direito - técnica, decisão, dominação. $4^{\text {a }}$ Ed. São Paulo: Atlas, 2003.

. Justiça material como um código fraco na comunicação normativa. In Estudos de Filosofia do Direito. $2^{\text {a }}$ Ed. São Paulo: Atlas, 2009.

FERREIRO, Consuelo. La crisis del principio favor laboratoris: a vueltas con la flexiguridad. In Questões Laborais, Ano XV, n⿳0 31, 2008, Coimbra Editora.

FERRI, Luigi. L'autonomia privata. Milano: Giuffrè, 1959.

Frediani, Yone. Flexibilização da CLT - impactos da flexibilização da legislação trabalhista no mercado de trabalho - o que não pode ser negociado. In Revista de Direito Constitucional e Internacional, v. 11, n. 44, julho-setembro de 2003, São Paulo.

FreITAS, Cláudio Victor de Castro. A parassubordinação, o contrato de trabalho a projeto e o direito brasileiro - uma análise das novas relações de trabalho sob uma ótica globalizada. In LTr: Revista de Legislação do Trabalho, v. 73, n 10, outubro de 2009, São Paulo.

FreITAS JÚNIOR, Antônio Rodrigues de. A negociação coletiva do trabalho e o projeto de reforma sindical de 2005. In Revista do Departamento de Direito do Trabalho e da Seguridade Social da Faculdade de Direito da USP, São Paulo, v. 1, n. 1, jan/jun (2006).

Galantino, Luisa. Diritto sindacale. 14ª edição. Torino: G. Giappichelli, 2006.

GARCIA, Gustavo Filipe Barbosa. Meio ambiente do trabalho: direito, segurança e medicina do trabalho. $3^{\text {a }}$ Ed.. São Paulo: Gen/Método, 2011.

García-Perrote Escartín, Ignacio. La reforma de la negociación colectiva (el Real Decreto-Ley 7/2011, de 10 de junio, de medidas urgentes). In Revista de información laboral, $n^{\circ} 6,2011$.

Gemignani, Tereza Aparecida Asta. Direitos coletivos e direitos fundamentais: o diálogo das fontes e a função promocional do direito. In Revista do Tribunal Superior do Trabalho, Brasília, vol. 78, nº 2, abr/jun de 2012. 
GENY, François. Methode d'interprétation et sources en droit prive positif: essai critique. $2^{\text {a }}$ Ed.. Vol. 1. Paris: Librairie générale de droit \& de jurisprudence, 1954.

GhezZI, Giorgio; Romagnol, Umberto. Il diritto sindacale. 4ª Ed.. Bologna: Zanichelli, 1997.

GIUGNI, Gino. Diritto sindacale. Bari: Cacucci Editore, 2012.

GoRZ, André. Adeus ao Proletariado. Rio de Janeiro: Forense, 1982.

Grotius, Hugo. The rights of war and peace. Disponível online em http://lfoll.s3.amazonaws.com/titles/553/0138_Bk.pdf, acesso em 01/12/2014, às $12 \mathrm{~h}$.

Gurvicth, Georges. The Problem of Social Law. In Ethics, vol. 52, nº 1, outubro de 1941.

HABERMAS, Jürgen. Direito e democracia - entre facticidade e validade. Vol. II. Rio de Janeiro: Tempo Brasileiro, 1997.

Hauriou, Maurice. A Teoria da Instituição e da Fundação. Porto Alegre: Sergio Antonio Fabris Editor, 2009.

Hobsbawn, Eric. Era dos extremos: o breve século XX. $2^{\text {a }}$ edição. São Paulo: Companhia das Letras, 1994.

Hooker, M. B. Legal Pluralism: An Introduction to Colonial and Neo-Colonial Laws. Oxford: Clarendor Press, 1965.

Horvath Junior, Miguel. Direito Previdenciário. 9a Ed.. São Paulo: Quartier Latin, 2012.

IANNI, Octavio. A era do globalismo. Rio de Janeiro: Civilização Brasileira, 1996.

ICHINO, Pietro. Autonomia colletiva e principio di libertà della concorrenza. In Lezioni di diritto del lavoro - Un approccio di labour law and economics. Milano, Giuffrè Editore, 2004. 
Jeammaud, Antoine. Droit du Travail. In Dictionnaire de la culture juridique (dir. D. Alland et S. Rials), Paris, PUF-Lamy, Coll. Quadrige, 2003.

KANT, Immanuel. Fundamentação da Metafísica dos Costumes. Lisboa: Edições 70, 2007.

KAYSER, Armand. Le fonti del diritto del lavoro nel diritto dei paesi membri della comunità - Rapporto ricapitolativo In BOLDT, Gerhard; DuRAND, Paul; HoRION, Paul; Kayser, Armand; Mengoni, Luigi; Molenaar, A. N. Le Fonti Del Diritto Del Lavoro. Comunità Europea del Carbone e dell'acciaio - Alta autorità, Luxemburgo, 1962.

Kelsen, Hans. Teoria Pura do Direito. São Paulo: Martins Fontes, 1999.

KILIAN, Dóris Krause. Negociação coletiva de trabalho. Porto Alegre: EDIPUCRS, 2003.

LEAL, Victor Nunes. Classificação das normas jurídicas. In LEAL, Victor Nunes. Problemas de direito público e outros problemas. Brasília: Ministério da Justiça, 1997.

LeIte, Carlos Henrique Bezerra. Curso de Direito do Trabalho. $5^{\text {a }}$ Ed.. São Paulo: Saraiva, 2014.

LeITE, Jorge. Código do Trabalho - algumas questões de inconstitucionalidade. In Questões Laborais: Código do Trabalho - questões de (in)constitucionalidade. Ano X, Coimbra Editora, Coimbra, 2003.

LÓPEZ TERRADA, Eva. La descentralización de la estructura de la negociación colectiva y las posibilidades de su articulación. Valencia: Tirant Monografías, 2000.

Magano, Octavio Bueno. A determinação da norma mais favorável In Anais do $\mathbf{X}$ Congresso Ibero-americano de Direito do Trabalho e da Seguridade Social, Montevideo, Abril de 1989, Tomo I.

. Direito coletivo e sociedade pluralista. In Revista do TST, 1991, disponível online em $\quad$ http://www.tst.jus.br/documents/1295387/b2753874-7ac1-48f5-8cee3957c95e 79b8, acesso em 02/11/2014, às $22 \mathrm{~h}$.

Liberalismo, corporativismo, pluralismo e neo-corporativismo. In Revista da Faculdade de Direito da Universidade de São Paulo - FDUSP, vol. 87, 1983. 
MAIOR, Jorge Luiz Souto. A supersubordinação - invertendo a lógica do jogo. In Revista do Tribunal Regional do Trabalho da $\mathbf{8}^{\text {a }}$ Região, v. 41, n. 81, suplemento especial comemorativo, julho-dezembro de 2008.

Malmesbury, Thomas Hobbes de. Leviatã ou A matéria, forma e poder de um estado eclesiástico e civil. $3^{\mathrm{a}}$ edição. São Paulo: Ícone, 2008.

MANnRICH, Nelson. Dispensa Coletiva: Da liberdade contratual à responsabilidade social. São Paulo: LTr, 2000.

. Empregabilidade, ocupação e novas formas de trabalho. In Revista da Faculdade de Direito da Universidade de São Paulo, v. 100, jan/dez de 2005.

. Pluralismo jurídico e Direito do Trabalho. In Revista do Advogado, Ano XXII, nº 66, junho de 2002, São Paulo.

. Relações entre legislado e negociado: vale a pena retomar esse debate? In Revista Brasileira de Filosofia, v. 237, 2011.

. Tendências atuais relativas ao âmbito pessoal do direito do trabalho em Portugal, Espanha e Brasil. In Revista de Direito do Trabalho, v. 34, no 130, abril-junho de 2008, São Paulo.

MAnus, Pedro Paulo Teixeira. Direito do Trabalho. $15^{\text {a }}$ Ed.. São Paulo: Atlas, 2014.

Maranhão, Délio. Direito do Trabalho. $7^{\text {a }}$ Ed.. Rio de Janeiro: Fundação Getúlio Vargas, 1979.

MARIUCCI, Luigi. Le fonti del Diritto del Lavoro - quindici anni dopo. Edizione aggiornata. Torino: G. Giappichelli, 2003.

Martinez, Pedro Romano et al. Código do Trabalho Anotado. 2a Ed.. Coimbra: Almedina, 2004.

Martinez, Pedro Romano. Direito do Trabalho. $3^{\text {a }}$ edição. Coimbra: Almedina, 2006. 
Martins, José Maria Ramos e Marques Neto, Agostinho Ramalho. Pluralismo Jurídico e Novos Paradigmas Teóricos. Porto Alegre: Sergio Antonio Fabris Editor, 2005.

Martins, Sergio Pinto. Direito da Seguridade Social. 34a Ed.. Atlas, São Paulo, 2014.

Direito do Trabalho. 30a edição. São Paulo: Atlas, 2014.

O pluralismo do Direito do Trabalho. Rio de Janeiro: Atlas, 2001.

Martins Filho, Ives Gandra da Silva. O bélico e o lúdico no direito e no processo. In Revista do Tribunal Superior do Trabalho, Brasília, vol. 70, 2, jul/dez de 2004.

- Valorização da negociação coletiva e flexibilização das normas legais trabalhistas. In Revista Jurídica, Brasília, v. 8, n. 79, jun./jul., 2006.

MASSONI, Túlio de Oliveira. Representatividade Sindical. São Paulo: LTr, 2007.

Matteucci, Nicola. Liberalismo. In Bobbio, Norberto, Matteucci, Nicola e PAsQuino, Gianfranco. Dicionário de Política. $11^{a}$ edição. Brasília: Editora Universidade de Brasília, 1998.

MAZEAUd, A. Droit du travail. $7^{\text {a }}$ edição. Paris: Montchrestien, 2010.

MeIRelles, Davi Furtado. Negociação coletiva no local de trabalho: a experiência dos metalúrgicos do ABC. Dissertação de mestrado apresentada à Pontifícia Universidade Católica de São Paulo (PUC-SP) em 2006.

Em defesa do acordo coletivo com propósito específico. In Revista da Faculdade de Direito de São Bernardo do Campo. São Bernardo do Campo, 2013, disponível online em http://www.direitosbc.br/Data/Sites/2/arquivos_servidor_fdsbc/revista_caderno/volume_19 2013/03 em-defesa-do-acordo-coletivo-com-propósito-espec\%C3\%ĀDfico.pdf, acesso em 28.11.2014, às $15 \mathrm{~h}$.

Menezes, Cláudio Armando Couce de. O negociado sobre o legislado. In Revista do Tribunal Superior do Trabalho (TST), Brasília, vol. 68, nº 2, abr/jun 2002. 
Mengoni, Luigi. Le fonti del diritto del lavoro in Italia. In Boldt, Gerhard; DuRAnD, Paul; Horion, Paul; Kayser, Armand; Mengoni, Luigi; MolenaAr, A. N. Le Fonti Del Diritto Del Lavoro. Comunità Europea del Carbone e dell'acciaio - Alta autorità, Luxemburgo, 1962.

Merino Segovia, Amparo. Concurrencia de convenios colectivos y nueva articulación de la negociación colectiva: un estudio del artículo 84 LET. In BAYLOS GRAU, Antonio P (coord.). La reforma laboral de 1994. Cuenca: Universidad de Castilla La Mancha, 1996.

Montoya Melgar, Alfredo. Derecho del trabajo. 29a Ed. Madri, Tecnos, 2008.

Moraes Filho, Evaristo de. Introdução ao Direito do Trabalho. Vol. I. Rio de Janeiro: Forense, 1956.

Moraes Filho, Evaristo de; e Moraes, Antonio Carlos Flores de. Introdução ao Direito do Trabalho. $10^{\text {a }}$ Ed.. São Paulo: LTr, 2010.

Moura, José Barros. A convenção colectiva entre as fonts de Direito do Trabalho. Coimbra: Almedina, 1984.

Nascimento, Amauri Mascaro. Compêndio de Direito Sindical. $6^{\text {a }}$ ed.. São Paulo: LTr, 2011.

. Curso de Direito do Trabalho. 25a edição. São Paulo: Saraiva, 2010.

Iniciação ao Direito do Trabalho. 39ª Ed. São Paulo: LTr, 2014.

. Limites da negociação coletiva na perspectiva de projeto de flexibilização da CLT. In Revista LTr, vol. 65, $\mathrm{n}^{\mathrm{o}}$ 12, dezembro de 2011.

OJeda Avilés, Antonio. Compendio de derecho sindical. 2a edição. Madri: Tecnos, 2012.

OLIVÉ, Leon. Discriminación y Pluralismo. Disponível online em biblio.juridicas.unam.mx/libros/5/2312/9.pdf, acesso em 16.01.2014, às $23 \mathrm{~h}$.

PAlOMEQue LóPez, Manuel Carlos. El nuevo reparto funcional de territorios normativos entre la ley y el convenio colectivo. In Relaciones Laborales, nº 17-18, septiembre 1994. 
Pastore, José. Atritos entre a Lei e a Realidade no Campo Trabalhista In Velloso, Carlos Mário da Silva et al (Coord.). Princípios Constitucionais Fundamentais. São Paulo: Lex Editora, 2005.

. Redução de jornada gera emprego? In Revista do Tribunal Superior do Trabalho, Brasília, vol. 75, no 2, abr/jun 2009.

PASQUIER, Claude du. Introduction à la théorie générale et à la philosophie du Droit. Paris: Delachaux \& Niestlé, 1979.

PereIRA, João Batista Brito. Notas sobre a flexibilização do Direito do Trabalho. In Revista do Tribunal Superior do Trabalho (TST), Brasília, vol. 68, no 2, abr/jun de 2002.

PereirA, José Luciano de Castilho. Futuro do direito e do processo do trabalho no brasil. In Revista do Tribunal Superior do Trabalho, Brasília, vol. 70, nº 2, jul/dez de 2004.

. O sindicato e sua força na negociação coletiva. In Revista do Tribunal Superior do Trabalho, Brasília, vol. 67, no 94, out/dez de 2001.

Persiani, Mattia. Dirittto Sindacale. 14ª Ed.. Padova: CEDAM, 2012.

PERULLI, Adalberto. Lavoro autonomo e dipendenza economica oggi In Rivista giurica del lavoro e della previdenza sociale, n. 2, anno LIV, aprile-giugno 2003.

PES, Luca Giuseppe. Il pluralismo giuridico (2003). Disponível online em http://www.dhdi.free.fr/recherches/theoriedroit/memoires/pesmemoir.pdf, acesso em $17 / 07 / 2014$, às $22 \mathrm{~h}$.

PESSI, Roberto. Ossservazioni sulla democrazia neo-corporata (a proposito di un libro di Francesco Galgano). In PESSI, Roberto (org.). Europa e concertazione: modelli a confronto. Padova, CEDAM, 2009.

Pimentel, José Menéres. $O$ direito do trabalho e as novas reformas. In III Congresso Nacional de Direito do Trabalho - Memórias. Coimbra: Almedina, 2000. 
PInson, Arnaud et SoukPRASEuth, Delphine. Retour sur l'ordre public en droit du travail et son application par la Cour de cassation. In Boletim de Informação da Corte de Cassação, $\mathrm{n}^{\mathrm{o}} 740$, de 15 de abril de 2011, disponível online em http://www.courdecassation.fr/IMG/pdf/Bicc_740.pdf, acesso em 12/10/2014, às $21 \mathrm{~h}$.

PIRES, Horário de Senna. Direito do Trabalho: a atualidade do princípio da proteção. In Revista do Tribunal Superior do Trabalho, Brasília, vol. 77, nº 2, abr/jun de 2011.

Ramalho, Maria do Rosário Palma. Ainda a crise do direito laboral: a erosão da relação de trabalho 'típica' e o futuro do direito do trabalho. In III Congresso Nacional de Direito do Trabalho. Coimbra: Almedina, 2000.

2000 .

Da autonomia dogmática do Direito do Trabalho. Coimbra: Almedina, Almedina, 2009.

Direito do Trabalho. Parte I - Dogmática Geral. $2^{\mathrm{a}}$ edição. Coimbra: Insegurança ou diminuição do emprego? A rigidez do sistema jurídico português em matéria de cessação do contrato de trabalho e de trabalho atípico. In $\mathbf{L T r}-$ Legislação do Trabalho, ano 64, $n^{\circ}$ 07, julho de 2000, São Paulo.

REALE, Miguel. Filosofia do Direito. 19ª ed. São Paulo: Saraiva, 2000.

Lições Preliminares de Direito. 27ª edição. São Paulo: Saraiva, 2012.

Robortella, Luiz Carlos Amorim. O conceito moderno de negociação coletiva. In Robortella, Luiz Carlos Amorim. Direito Sindical Brasileiro: estudos em homenagem ao Prof. Arion Sayão Romita. São Paulo: LTr, 1998.

Rodrigues, Leôncio Martins. Destino do Sindicalismo. Rio de Janeiro: Centro Edelstein de Pesquisas Sociais, 2009.

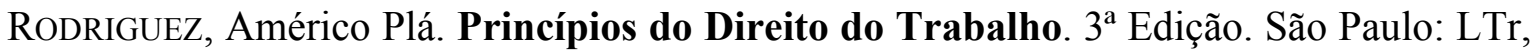
2004.

Rodriguez-Piñero, Miguel. Principio pro operario, condición más beneficiosa y autonomía colectiva. In Relaciones laborales: Revista crítica de teoría y práctica, $\mathrm{N}^{\mathrm{o}} 1$, 1991. 
Romagnoli, Umberto. Weimar, ¿y después?. In Colección estructuras y procesos Serie $\mathbf{1}^{\mathbf{0}}$ de Mayo. Madrid: Trota, 1992.

Romano, Santi. O ordenamento jurídico. Florianópolis: Fundação Boiteux, 2008.

RomitA, Arion Sayão. A flexibilização e os princípios do direito do trabalho. In RoMITA, Arion Sayão. Direito do Trabalho - Temas em Aberto. São Paulo: LTr, 1988.

- O Princípio da Proteção em Xeque. Disponível online em http://www.planalto.gov.br/ccivil_03/revista/Rev_36/artigos/Art_Arion.htm. Acesso em 17.10.11, às $16 \mathrm{~h} 30 \mathrm{~min}$.

O princípio da proteção em xeque e outros ensaios. LTr: São Paulo, 2003.

Rousseau, Jean-Jacques. Do contrato social ou Princípios do Direito Político. São Paulo: Martin Claret, 2008.

RouXINOL, Milena Silva. O princípio do tratamento mais favorável nas relações entre a lei e a convenção colectiva de trabalho. In Questões Laborais, Ano XIII, $\mathrm{n}^{\mathbf{0}}$ 28, 2006, Coimbra Editora.

RuBIO, David Sánchez. Pluralismo jurídico e emancipação social. In WOLKMER, Antonio Carlos et al. Pluralismo Jurídico: os novos caminhos da contemporaneidade. $2^{a}$ edição. São Paulo: Saraiva, 2013.

Rusciano, Mario. La metamorfosi del contratto collettivo. In Riv. trim. dir. proc. civ., ano 2009 , n. 01.

SAla Franco, Tomás. El derecho constitucional a la negociación colectiva. In CASAS BAAMOnde, María Emilia et al (org.). Las Transformaciones del Derecho del Trabajo en el Marco de la Constitución Española: Estudios en Homenaje al Profesor Miguel Rodriguez-Piñero y Bravo- Ferrer. Madrid: La Ley, 2006.

SAntoro-PAssarelli, Giuseppe. Dirito Sindacale. Bari: Laterza, 2007.

SAntos, Boaventura de Souza. Crítica de la Razón Indolente - Contra el desperdicio de la experiencia. Vol. 1. Bilbao: Editorial Desclée de Brouwer S.A., 2003. 
O discurso e o poder - ensaio sobre a sociologia da retórica jurídica.

Porto Alegre: Sergio Antonio Fabris Editor, 1988.

The Law of the oppressed: the construction and reproduction of legality in Pasárgada. In Law and Society Review, vol. 12, n. 1, 1977.

SAntos, Ronaldo Lima dos. Teoria das normas coletivas. $2^{\mathrm{a}}$ edição. São Paulo: LTr, 2009.

SERrano, Carlos García et al. Dos questiones claves de la reforma laboral: despidos y negociación colectiva. In Temas Laborales - Monográfico sobre La Reforma Laboral de 2010, $\mathrm{n}^{\circ}$ 107/2010, Consejo Andaluz de Relaciones Laborales.

Silva, Homero Batista Matheus da Silva. Curso de Direito do Trabalho Aplicado Parte Geral. 2a Ed. Rio de Janeiro: Elsevier, 2013.

Silva, Luiz de Pinho Pedreira. Um novo modelo social: a flexissegurança. In LTr: revista legislação do trabalho, v. 69, n. 6, São Paulo, jun. 2005.

Silva, Maria Manuela Maia da. Flexibilidade e rigidez das leis laborais - as novas formas de contratação. In IV Congresso Nacional de Direito do Trabalho. Coimbra: Almedina, 2002.

Silva, Otavio Pinto e. A função do direito do trabalho no mundo atual. In CorreiA, Marcus Orione Gonçalves (Org.). Curso de Direito do Trabalho - Teoria Geral do Direito do Trabalho. V. 1. São Paulo: LTr, 2007.

Fontes do direito do trabalho. In Revista da Faculdade de Direito da Universidade de São Paulo - FDUSP, vol. 96, 2001.

SiLva, Walküre Lopes Ribeiro da. Autonomia Privada Coletiva. In Revista da Faculdade de Direito da Universidade de São Paulo, v. 102, 2007.

. Autonomia privada coletiva e o direito do trabalho. In Revista de Direito do Trabalho, n$^{\circ}$ 97, ano 26 - jan/mar de 2000, São Paulo, Revista dos Tribunais. 
. Direito do trabalho brasileiro: principais aspectos de sua evolução histórica e as propostas de modernização. In Revista do Tribunal Superior do Trabalho, Brasília, vol. $69, \mathrm{n}^{\mathrm{o}} 2$, jul/dez de 2003 .

. Liberdade sindical no contexto dos direitos humanos: a experiência da OIT.

In Revista do Departamento de Direito do Trabalho e da Seguridade Social da Faculdade de Direito da USP, ano 1, nº 1, 2006.

SuPIOT, Alain; et al.. Transformações do trabalho e futuro do Direito do Trabalho na Europa. Coimbra: Coimbra, 2003.

SüSSEKInd, Arnaldo. Flexibilização da legislação trabalhista. In Folha de São Paulo, São Paulo, edição de 27 de novembro de 2001, Tendências/Debates.

TeIXeIra, Sérgio Torres et BARroso, Fábio Túlio. Os princípios do direito do trabalho diante da flexibilidade laboral. In Revista do Tribunal Superior do Trabalho, Brasília, vol. $75, n^{\circ} 3$, jul/set de 2009.

TeIXeIRA FILHo, João de Lima. Uma proposta de reforma da legislação do trabalho. In Revista do Ministério Público do Trabalho, Brasília, $\mathrm{n}^{\circ} 06-2^{\circ}$ semestre - setembro de 1993.

Telles Junior, Goffredo da Silva. Em nome do povo... In Revista da Faculdade de Direito da Universidade de São Paulo - FDUSP, vol. 97, 2002.

TEYssiÉ, Bernard. Droit du travail - Relactions collectives. $4^{\mathrm{a}}$ Edição. Paris, Lexis Nexis, 2005.

TOPO, Adriana. Legge e autonomia collettiva nel lavoro pubblico. Padova: CEDAM, 2008.

Trotta, Maurice S. Collective Bargaining - Principles, Practices, Issues. Nova Iorque: Simmons-Boardman Publishing Corporation, 1961.

Uguina, Jesús R. Mercader. La silenciosa decadencia del principio de normas más favorable. In CIVITAS - Revista Española de Derecho del Trabajo, $\mathrm{n}^{\mathbf{0}}$ 109, Enero-Febrero 2002, Madri. 
VALDÉS DAL-RE, Fernando. El sistema español de negociación colectiva: entre la continuidad y el cambio. In Relaciones laborales: Revista crítica de teoría y práctica, $\mathrm{n}^{\mathrm{o}}$ 9, 2011.

VAllebona, Antonio. Istituzioni di diritto del lavoro - Il diritto sindacale. $6^{\text {a }}$ ed.. Padova: CEDAM, 2008.

VARgAS, Luiz Alberto de et al. Setenta anos da CLT: a atualidade do direito social no século XXI. In Revista do Tribunal Superior do Trabalho, Brasília, vol. 79, nº 2, abr/jun de 2013.

Vianna, Francisco José de Oliveira. Problemas de Direito Sindical. Rio de Janeiro: Max Limonad, 1943.

Vianna, Segadas. Antecedentes históricos. In SÜSSEKIND, Arnaldo et al. Instituições de direito do trabalho. Vol. 1. 22a Ed.. São Paulo, LTr, 2005.

Vicente Palacio, Arantzazu. La negociación colectiva. In García NinEt, José Ignacio (dir.) e García Viña, Jordi (coord.). Manual de derecho sindical. $3^{\text {a }}$ edição. Barcelona, Atelier, 2011.

Vigneau, Christophe. Le principe de faveur dans le régime du temps de travail en droit comparé. In LAULOM, Sylvaine. Recomposition des systèmes de représentation des salariés en Europe. Université de Saint-Etienne, 2005.

Wolkmer, Antonio Carlos. Pluralismo Jurídico: fundamentos de uma nova cultura no direito. $3^{\text {a }}$ ed. São Paulo: Alfa Omega, 2001.

Pluralismo jurídico: um espaço de resistência na construção dos direitos humanos. In WOLKMER, Antonio Carlos et al. Pluralismo Jurídico: os novos caminhos da contemporaneidade. $2^{\mathrm{a}}$ edição. São Paulo: Saraiva, 2013.

XAVIER, Bernardo da Gama Lobo. Flexibilidade e Rigidez das Leis Laborais. Novos Modelos de Prestação do Trabalho. In IV Congresso Nacional de Direito do Trabalho. Coimbra: Almedina, 2002.

Convenções colectivas, usos e o sistema de fontes de direito do trabalho (art. $^{0} \mathbf{1}^{\circ} \mathbf{e ~ 4}^{\mathbf{0}}$ do CT). In VII Congresso Nacional de Direito do Trabalho - memórias. Coimbra: Almedina, 2004. 
Xavier, Brito. Crise do Direito do Trabalho. In III Congresso Nacional de Direito do Trabalho - Memórias. Coimbra: Almedina, 2000.

Zylberstajn, Hélio.. Novos padrões de negociação coletiva: perspectivas do contrato coletivo de trabalho no Brasil. Painel de debates coordenado por Marco Antônio de Oliveira. Texto integral dos debates disponível online em http://www.cebrap.org.br/v1/upload/biblioteca_virtual/NOVOS_PADROES_DE_NEGOC IACAO_COLETIVA_PERSPECTIVAS.pdf, acesso em 23.12.2010, às 18h.

. Os metalúrgicos do $\mathrm{ABC}$ : tentando construir o novo/velho sindicato no Brasil. Trabalho apresentado em dezembro de 2002 à FIPE - Fundação Instituto de Pesquisas Econômicas. Disponível online em http://www.fea.usp.br/feaecon//media/livros/file_298.pdf, acesso em 22/11/2014, às 14h.

. Reforma Trabalhista. Caderno Opinião - Estadão.com.br. 18 de janeiro de 2011. 